T눈

Cultivation and Preparation OF

PARA RubBer

W. H. JOHNSON 


\section{UNIVERSITY OF CALIFORNIA}

AT LOS ANGELES

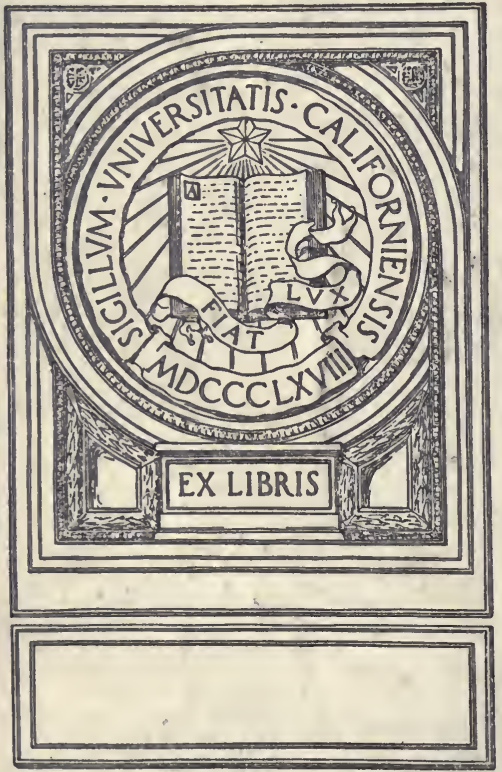




THE CULTIVATION AND PREPARATION OF PARA RUBBER 


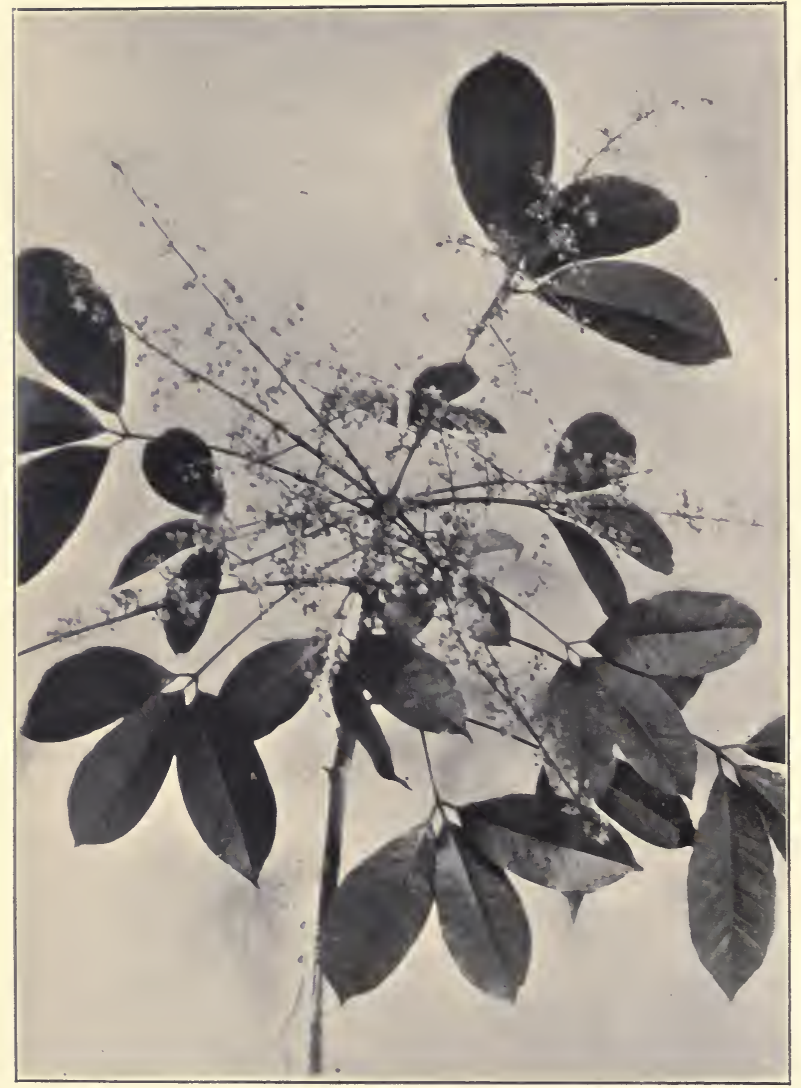

Fig, I.-Flowering Branch of the Para Rubber Tree (Hevea brasiliensis).

(By permission of the Publishers of "The India-rulber Tournal.") 


\section{T H E}

\section{Cultivation and Preparation}

$\mathrm{OF}$

\section{PARA RUBBER}

BY

W. H. JOHNSON, F.L.S.

EX-DIRECTOR OF AGRICULTURE, GOLD COAST COLONY, WEST AFRICA DIRECTOR OF AGRICULTURE, MOZAMBIQUE COMPANY, EAST AFRICA

Commissioned by Government in 1902 to visit Ceylon to Study the Methods cmployed there in the Cultivation and Preparation of Para Rubber and other Agricultural

Staples for Market, with a view to introduce them into West Africa

\section{Waitb HAumerous Fllustrations}

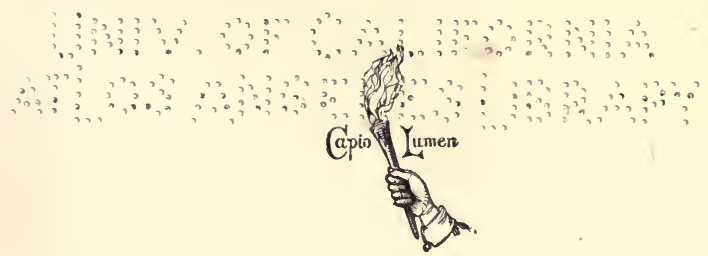

\section{LONDON}

CROSBY LOCKWOOD A N D SON

7 STATIONERS' HALL COURT, LUDGATE HILL 


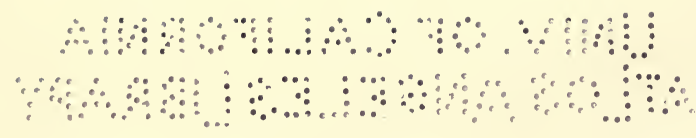

Printed at THE DARiex PRESS, Edinburgh. 


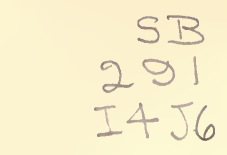

-PREF A C E.

THE principal object I have in view in writing this small treatise on the Cultivation and Preparation of Para Rubber, is to endeavour to give to the continually increasing number of persons taking up rubber cultivation such practical advice on the various matters connected with that comparatively new industry as would be likely to assist them in their undertaking.

Although the cultivation of Para rubber is at the present time almost limited to a few countries in the Eastern Tropics of the Old World, there is every prospect of its being further extended in those regions, and also of being taken up largely in the Western Tropics.

There are in Tropical Africa thousands of square miles of land suitable for the cultivation of the Para rubber tree. Upon a large extent of this land rubber-producing plants were at one time abundant, but now year by year their number is being gradually diminished, as the result of the disastrous methods of tapping employed by the native rubber collectors.

The question of replanting these areas with Para rubber trees is well worth the consideration of the administrative authorities, and especially those in our various West African possessions.

In order to supplement the information here given as the 
result of my own observations in Ceylon and West Africa, I have not hesitated to make frequent extracts from the India-rubber Journal, the Straits Settlements Agricultural Bulletin, and $\mathrm{Mr}$ Arden's “ Report on Para Rubber in the Malay Peninsula." For these extracts, I have obtained the kind permission of the Editors of the two first-mentioned publications and the Author of the latter.

W. H. JOHNSON.

Royal Botanic Gardens,

KEw, S.W., September 1904. 


\section{PREFACE TO THE SECOND EDITION.}

THE first edition of this work was also the first book dealing exclusively with the Cultivation and Preparation of Para Rubber published in the English language. Although less than four years old, it is out of print, and owing to the rapid development of the rubber-planting industry is to a large extent out of date.

The second edition includes all the latest authentic information, and covers a far larger range of subjects likely to be of interest or utility to those in any way connected with the rubber industry.

To better enable this to be effected, all the principal works dealing with the subject have been consulted, among them being :-

Seeligmann's “Le Caoutchouc et la Gutta Percha” ; Weber's "Chemistry of India-rubber"; Journal d'Agriculture Tropicale; Obach's "Cantor Lectures"; India-rubber Journal; Tropical Agriculturist; Bulletins of the Royal Botanic Gardens, Kew, Imperial Institute, Royal Botanic Gardens, Ceylon, Straits Settlements and Federated Malay States, Department of Agriculture for the West Indies, Institute of Commercial Research in the Tropics, Liverpool; Journal of Botany; Der Tropenpflanzer; Wright's “Hevea brasiliensis”; Revue des Cultures Coloniales; 
L'Agriculture pratique des pays chauds; Journal of the Royal Society of Arts, and Tropical Life.

New methods of collecting and preparing rubber are being frequently evolved, and in view of the industry's comparative infancy there is every probability that what are to-day recognised as up-to-date, or standard, systems, will in a few years be considered quite obsolete.

I wish to register my indebtedness to numerous friends who have assisted me in compiling this edition, and to my friend, Mr J. H. Holland, for kindly revising the proof sheets.

\section{W. H. JOHNSON.}

Beira, South-East Africa, necember 1908. 


\section{CONTENTS.}

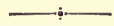

CHAPTER I.

PAGE

INTRODUCTORY

CHAPTER II.

The World's Production and Consumption of Rubeer -

Wild Rubber-Cultivated Rubber-Labour-Epidemics-Artificial or Synthetic Rubber.

CHAPTER III.

The Para Rubber Tree at Home and Abroad

\section{CHAPTER IV.}

Propagation

Seed Selection-Seed Sowing-Propagating Young Growths.

\section{CHAPTER V.}

\section{Planting and Cultivating}

Site for I'lantation-Plotting-out the Estate-Distance Apart to Plant the Trees--Transplanting - Between-crops and Catch-cropsWeeding and Harrowing-Disbudding and Pruning.

\section{CHAPTER VI.}

\section{SOILS AND MANURES}

Chemical, Physical, and Biological Condition of Soils-Manuring.

\section{CHAPTER VII.}

PESTS

Conditions which favour the spread of Disease-Fungus DiseasesFungicides-Insect Pests-Insecticides.

\section{CHAPTER VIII.}

LATEX

Functions of Latex-Chemical and Physical Properties of LatexStoring Latex. 
Tapping-Tapping Implements-The Laticiferous System of the Para Rubber Tree-Flow of Latex Increased by Wounding the TreeWhen to Tap-V-Vhaped Incisions-Herring-bone-shaped Incisions-Spiral Incisions-Pricking-Various Methods of Tapping -General Remarks on Tapping-Collecting Vessels-Tapping Areas.

\section{CHAPTER X.}

\section{Rubper Manufacture}

Properties of Rubber-Caoutchouc-Resin-Proteids-Mineral Matter -Effects of Vulcanisation - Preparation of Rubber from the Latex -Suggested Method for Preparing Rubber Biscuits on Small Estates-A Centrifugal Strainer-Coagulating Machines-Crêpe and Washed Rubber-Worm Rubber-Lace Rubber-Flake Rubber-Block Rubber-Scrap Rubber-Washing MachinesThe Rubber Factory.

\section{CHAPTER XI.}

THE ANTISEPTiCisAtion OF RUBbeR

Defects of Plantation Rubber-Creosoting the Latex-Coagulation with Formic Acid - Discoloration of Rubler and Oxidising Enzymes-Tackiness.

\section{CHAPTER XII.}

DRYing AND PACKING RUBber FOR EXPORT

Drying the Rubber-Vacuum Drying-Packing Rubber for Export.

\section{CHAPTER XIII.}

Yield of Para Rubier from Cultivated Trees

Ceylon-Malay Peninsula-Gold Coast, West Africa, from Variuus Estates in 1905, 1906, 1907, 1907-8.

\section{CHAPTER XIV.}

Establishment and Maintenance of a Para Rubber Plantation -

Estimated Cost in Ceylon and Malaya.

\section{CHAPTER XV.}

Commercial Value of the Oil in Hevea Seeds - $\quad$ - 169 


\section{LIST OF ILLUSTRATIONS.}

FIG.

1. Flowering Branch of the Para Rubber Tree (Herea brasiliensis)

2. One of the Parents of the Para Rubber Industry in the East, Frontispiece growing in the Botanic Garden, Heneratgoda, Ceylon

3. Para Rubber Trees planted in the Tarkwa Botanic Station, Gold Coast, West Africa, in June 1904

4. Para Rubber Seedlings, six months old, in a Nursery on the Guara

Guara Co.'s Estate near Beira, East Africa - _ $\quad 3$ - 3

PAGE

5. The "Universal Ant Destroyer" - _ _ _ _ _ $\quad 6$ -

6. The Eastern Produce and Estate Company's Tapping Implement 70

7. The "Bowman-Northway" Tapping Implements - _ $\quad$ - 72

8. The "Michie-Golledge " Tapping Tool - $\quad$ - $\quad$ - $\quad$ - 73

9. Miller's Patent Tapping and Paring Knife - $\quad$ - $\quad$ - $\quad$ - 74

Io. Modified Form of the "Christophe "Tapping Knife _ _ - 75

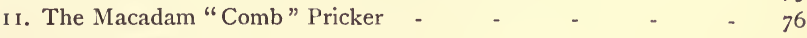

12. Relative Size and Position of V-Incisions - $\quad$ - $\quad$ - 79

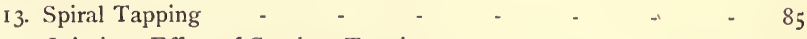

I3A. Injurious Effect of Careless Tapping - $\quad-\quad$ - $\quad-\quad 85$

14. Oblong and Round Coagulating Pans, Collecting Cup, and Pail

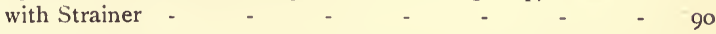

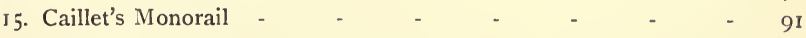

16. Rolling Para Rubber "Biscuits" on an Estate in Ceylon, Latex in

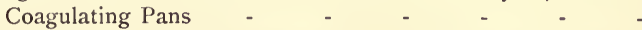

17. Para Rubber "Biscuits" being dried in a Tea-leaf Withering

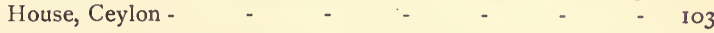

I8. "Michie-Golledge" Rubber Coagulating Machine - - I Io

19. Sectional Diagram of the "Michie-Golledge" Rubber Coagulating Machine

20. Walker's "Worm " Rubber Cutting Machine

21. The "K.L." Coagulator

22. Messrs David Bridge \& Co.'s Block Rubber Press - - II7

23. Messrs Francis Shaw \& Co.'s Hydraulic Blocking Press - - II8 
FIG.

24. A Small Size Washing Machine - _ _ _ _ _ - I2I

25. Breaking-up and Crêping Machines $\quad$ - $\quad$ - $\quad$ - $\quad$ - 122

26. Plan of Factory for Washing, Drying, and Blocking Rubber, Driven by a Semi-Portable Steam Engine - - - 124

27. Plan of Factory for Washing, Drying, and Blocking Rubber,

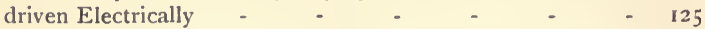

28. Plan of Dr Olsson-Seffer's Patent System of Washing, Pressing, and Drying Rubber - $\quad$ - $\quad$ - $\quad$ - $\quad$ - $\quad$ -

29. The "Da Costa" Patent System of Rubber Coagulation - _ - I3I

30. The "Passburg" Vacuum Drier - $\quad$ - $\quad$ - $\quad$ - $\quad$ - 39

3r. The "Scott" Patent Drying Stove - - - - - - $14 \mathrm{I}$

32. Messrs David Bridge \& Co.'s Complete Vacuum Drying Plant for Rubber, \&c. 


\title{
THE CULTIVATION AND PREPARATION OF PARA RUBBER.
}

\author{
CHAPTER I. \\ INTRODUCTORY.
}

RUBBER, or caoutchouc, is obtained from the latex, or milky juice, present in the tissues of a large variety of plants peculiar to tropical and subtropical regions. The word caoutchouc is apparently corrupted from the native word caaochô or caaochu, derived from caa, meaning wood, and $o-c h \hat{b}$ or $o-c h u$, to run or weep-hence, timber that runs or weeps. It is supposed to have been first discovered in South America more than four hundred years ago. In 1770 Priestly recommended it for erasing leadpencil marks. More than fifty years later, Macintosh established the industry for manufacturing waterproof garments, some of which are known by his name to the present day. In I 836 Thomas Hancock discovered that crude rubber, when cut up, pressed, and submitted to heat, could be converted into a condition capable of being transferred to practically any shape or form. It was not, however, employed extensively in commerce until after I874, when the method of vulcanising rubber, by heating and treating it with sulphur, was discovered. The imports of rubber into England at that time amounted to about 7,500 tons per annum. From then onwards they steadily rose, until in 1896 they amounted to nearly 20,000 tons. But the extensive use of rubber in the manufacture of cycle, carriage, and motor tyres and electrical appliances has of late years caused the demand to increase to an enormous extent, and the imports of rubber have risen by leaps and bounds. 
It is estimated that the world's annual consumption of rubber at the present time is about 65,000 tons, valued at about £ $19,000,000$. The following table illustrates the growth of the rubber industry in the United Kingdom since I830:-

Rubber Imported into the United Kingdom.

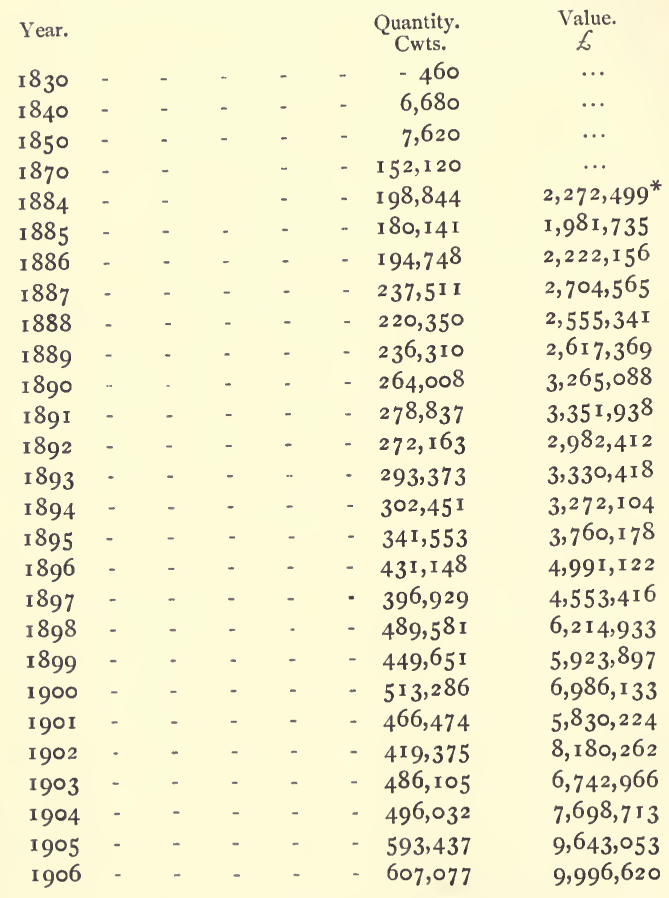

The trees producing the rubber known in commerce as "Para" furnish more than one half of the world's supply. They belong to the genus Hevea; of these Hevea brasiliensis is the most important species, which, as its specific name suggests, is indigenous to Brazil. 
While the demand for rubber continues to increase, the supplies from some sources are steadily decreasing. This is especially the case from different parts of Africa, which furnish a considerable portion of the world's supply. The decrease is largely owing to the disastrous methods employed by the natives in collecting rubber.

It must, however, be borne in mind that the imports of rubber from some other countries have considerably increased during recent years, and have more than compensated for the failure of other supplies. Of these Brazil, Uruguay, and Peru are amongst the most important. The exports of rubber from the Amazon valley alone rose from 22,216 tons in $1896-1897$, to 29,997 tons in 1901-1902.

Until quite recent years rubber was obtained solely from plants growing wild, but as the demand threatened to exceed the supply, attention was drawn to the advisability of meeting this demand by cultivating rubber-producing plants on an extensive scale.

It has been objected that the cost of establishing plantations of rubber trees would prohibit the rubber produced by them competing in the market with that collected by natives from wild trees. In regard to this question, the difficulties under which the native collector labours must be taken into consideration. The collection of rubber from wild trees often necessitates the undertaking of long and arduous journeys of several weeks' duration, in order to reach a rubber-producing district. It must. also be borne in mind that the collection of rubber in a mixed forest, where rubber trees are comparatively scarce, is far more expensive than it would be in a plantation, and requires a frequent change of headquarters.

Again, there is no comparison between the facilities provided on a plantation for curing the rubber and those obtainable in the forest. If there be added to all these considerations the cost of transport the objection becomes untenable.

The rubber prepared from cultivated trees is generally rated at a higher market price than that collected from wild trees in consequence of its greater purity. The loss from "fine Para" is from io to 15 per cent. in manufacture, whereas that from the "biscuit" rubber prepared from cultivated Para rubber trees is generally less than I per cent. 
The cultivation of rubber trees has already been so successfully accomplished in India, Ceylon, the Malay Peninsula, South America, and some other countries, that the attention of large numbers of persons interested in tropical planting has been directed to the possibility of recuperating their losses, due to the over-production of some other products, by planting rubber trees. Hevea brasiliensis, the tree producing the Para rubber of commerce, has been the one most favoured by planters.

The successful manner in which the Para rubber tree was introduced to our Eastern tropical possessions by the Indian Government in 1876 , through the agency of the Royal Botanic Gardens, Kew, at a cost of over $£ 1,500$, is well known, and need not be detailed here.

As the result of this introduction, an important agricultural industry has developed in the Malay Peninsula and Ceylon. An illustration of one of the parent trees of this industry, now growing in the Heneratgoda Botanic Garden, Ceylon, is given (Fig. 2). Para rubber has practically ruled the market price of rubber since its first introduction to commerce. But the product of the cultivated trees, being more carefully prepared than that from the indigenous trees in Brazil, is often rated at a much higher price than the latter.

It is estimated that there are now about 155,000 acres planted with this tree in Ceylon, while in the Malay Peninsula there is a still larger area under Para rubber cultivation. The small amount of cultural skill required to successfully cultivate the Para rubber tree, coupled with the high prices paid for the rubber which the cultivated trees produce in comparison with that paid for other grades of rubber, has no doubt largely influenced planters in selecting the Para tree in preference to other rubber-producing plants.

The following reports illustrate the high prices paid for the rubber obtained from cultivated Para rubber trees, as against those obtainable for rubber from other sources:-

W. 11. Johnson, Esq., 44 AND 45 FEnChurch Street, Royal Gardens, Kew.

London, E.C., IIth February 1903.

DEAR SiR,-In reply to yours of the $5^{\text {th }}$ inst., we give you below comparison of prices of Ceylon fine rubber and hard cure fine Para rubber :- 


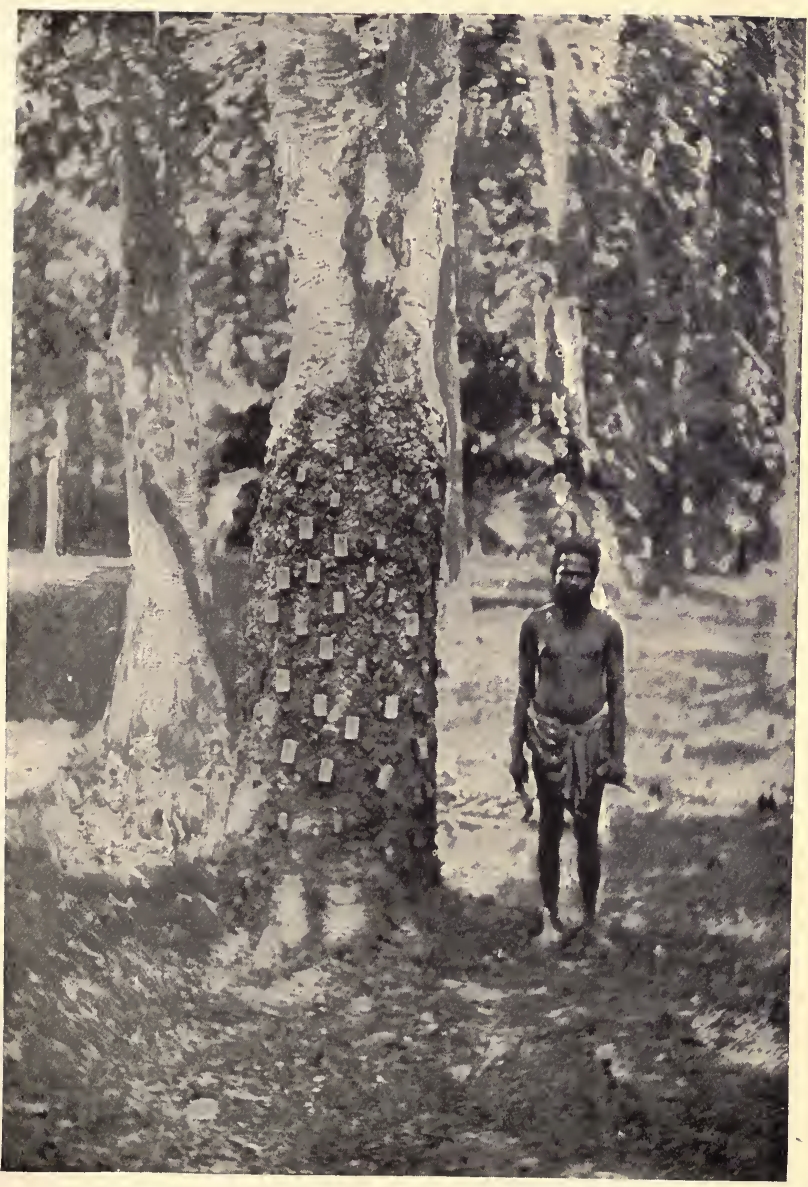

FIG. 2.-One of the parents of the Para Rubber Industry in the East, growing in the Botanic Garden, Heneratgoda, Ceylon. (From a photograph by the Author.) 



\begin{tabular}{|c|c|c|}
\hline Date. & Ceylon Fine Sold. & $\begin{array}{l}\text { Value of Hard } \\
\text { Fine Para. }\end{array}$ \\
\hline $\begin{array}{l}\text { July 18, 1902 } \\
\text { Aug. 1, 1902 } \\
\text { Aug. 29, 1902 } \\
\text { Sept. 1 2, 1902 } \\
\text { Oct. 1 7, 1902 } \\
\text { Dec. 12, 1902 } \\
\text { Jan. 9, 1903 } \\
\text { Jan. 23, 1903 }\end{array}$ & 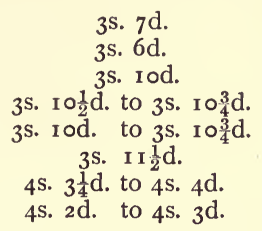 & 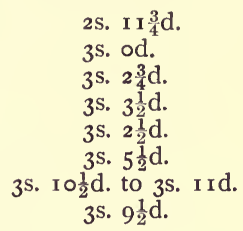 \\
\hline
\end{tabular}

So far we have only had small lots from Ceylon, which have been keenly competed for here. The rubber seems to be much liked.

We are, dear Sir,

Yours faithfully,

S. FIGGis \& Co.

Messrs Hecht, Levis, \& Kahn to Royal Gardens, Kew.

36 Fenchurch Street, London, E.C., I9th December 1902.

DEAR SIR,-We have examined the samples of Para rubber from Selangor which you submitted to us. We are, of course, not chemists, and can only judge the rubber from its elasticity, strength, and freedom from dirt.

With ordinary hard cure fine Para worth to-day 3 s. $8 \mathrm{~d}$. per lb., we should estimate the value of your samples as follows :-

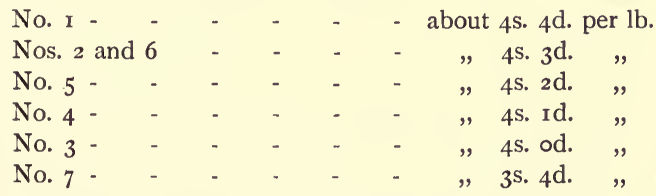

Nos. 3 and 4 are decidedly weaker than the others, and on the whole we think the less acid used in coagulation the better. Sample No. I, coagulated without acid at all, is certainly the best of the lot.

We remain, \&c.,

Неснт, Levis, \& KaнN. 
PARA RUBBER.

The tables given below show the approximate maximum and minimum prices paid for "Fine Para" and cultivated Para respectively from the year I903 up till April I908:-

\begin{tabular}{|c|c|c|c|c|c|c|c|c|}
\hline \multicolumn{4}{|c|}{ Year. } & \multicolumn{3}{|c|}{ Fine Para. } & \multicolumn{2}{|c|}{ Cultivated Para. } \\
\hline & & & & $\begin{array}{c}\text { Maxir } \\
\text { s. }\end{array}$ & $\begin{array}{l}\text { mum. } \\
\text { d. }\end{array}$ & $\begin{array}{l}\text { Minimum. } \\
\text { s. d. }\end{array}$ & $\begin{array}{l}\text { Maximum. } \\
\text { s. d. }\end{array}$ & $\begin{array}{l}\text { Minimum. } \\
\text { s. d. }\end{array}$ \\
\hline 1903 & - & - & - & 4 & 9 & 35 & 49 & $4 \quad I$ \\
\hline I 904 & - & - & - & 5 & 5 & 310 & 6 & 46 \\
\hline $1905^{*}$ & - & - & - & 5 & 9 & 49 & 6 & 510 \\
\hline 1906 & - & - & - & 5 & 5 & 50 & 63 & 55 \\
\hline 1907 & - & - & - & 5 & 3 & 33 & 59 & 3 \\
\hline $1908(\mathrm{~A}$ & April) $\dagger$ & & - & 3 & 7 & 29 & 310 & 30 \\
\hline
\end{tabular}

* Kew Bulletin, No. 7, 1906.

+ India-rubber Journal, 2oth April 1908. 


\section{CHAPTER II.}

\section{THE WORLD'S PRODUCTION AND CONSUMPTION OF RUBBER.}

ONE of the first considerations of the prospective rubber planter should be the probability of his obtaining a lucrative market for his crop when his trees arrive at maturity. In order to assist him to solve this important problem, let us investigate the conditions affecting those predominating factors of the rubber trade-supply and demand.

The world's production of rubber during the year 1907 is estimated at 69,000 tons. Messrs S. Figgis \& Co., the wellknown rubber brokers, signifiçantly point out, in their annual review of the rubber market for that year, that the consumption was probably 3,000 tons less than the supply, or about equivalent to that of the year 1906.

The stock of rubber on hand at Liverpool in January 1908 was 2,300 tons, which was the largest surplus for the previous twelve years.

The world's annual consumption of rubber for the period July I 899 to January 1908 is estimated as follows :-

\begin{tabular}{|c|c|c|c|c|c|c|c|c|}
\hline \multicolumn{6}{|c|}{ Year. } & Tons. & Increase. & Decrease. \\
\hline July & I 899 & to June & I900 & - & - & $48,35^{2}$ & $\begin{array}{c}\text { Per Cent. } \\
\ldots\end{array}$ & $\begin{array}{c}\text { Per Cent. } \\
\ldots\end{array}$ \\
\hline " & 1900 & , & I 901 & . & - & $5^{1,1} 3^{6}$ & 5.8 & $\ldots$ \\
\hline , & I90I & , & 1902 & - & - & 51,170 & 0.1 & $\cdots$ \\
\hline ", & 1902 & , & 1903 & - & - & 55,276 & 8.0 & $\ldots$ \\
\hline , & 1903 & , & 1904 & - & - & 59,666 & $7 \cdot 9$ & $\ldots$ \\
\hline , & I904 & " & 1905 & - & - & $6_{5}, \circ 8_{3}$ & 9. I & $\ldots$ \\
\hline " & 1905 & , & 1906 & - & - & 62,574 & $\ldots$ & 3.9 \\
\hline " & 1906 & - & - & - & - & 66,000 & $\ldots$ & $\ldots$ \\
\hline , & 1907 & - & - & - & - & 66,000 & $\cdots$, & $\ldots$ \\
\hline
\end{tabular}

July I 899 to June 1906 compiled from figures supplied by Messrs Hecht, Levis, \& Kahn.

January 1906 to December 1907, Messrs S. Figgis \& Co.'s annual review of the rubber trade for 1907 . 
The American financial crisis is suggested as a cause of the non-increase of consumption during 1907, when many rubber factories in that country closed down.

IVith regard to the anticipated consumption of rubber in I908, Messrs S. Figgis \& Co., loc. cit., state: "We do not expect much increase of consumption in 1908 in the present state of trade and the over-production of motors everywhere this season." Assuming the above figures to be correct, it will be seen that the rate of annual increase of consumption during recent years has been less than 5 per cent.

The total quantity of cultivated rubber exported from the East in I9O7 was I,OIO tons. The total world's production of cultivated rubber for that year was probably less than 2,000 tons, so that the various sources of wild rubber more than met the demand, and this state of affairs has obtained since the establishment of the rubber industry.

\section{WILD RUBBER.}

Of the world's total production of rubber, tropical America contributes 63 per cent., tropical Africa 34 per cent., and Asia 3 per cent.

The principal source of wild rubber is Brazil, which, during the year 1905, exported 31,474 tons, 38,000 tons in 1906, and $4 \mathrm{I}, 500$ in 1907 , or over 60 per cent. of the total world's supply. This amount was mainly derived from wild Hevea trees, which, as will be shown later, are not readily destroyed by tapping. The Heveas in the Amazon valley have been continuously exploited for more than half a century.

Spruce writes in Hooker's Journal of Botany, vol. vii., I855, pp. 193-196: "IVhen I ascended the Rio Negro in I85 I, I pointed out to the inhabitants the abundance of Seringa trees they possessed in their forests, and tried to induce them to set about extracting the gum; but they shook their heads, and said it would never answer. At length the demand for india-rubber, especially from the United States, began to exceed the supply; the price consequently rose rapidly, until early in I 854 it reached the extravagant sum of 38 milreis the arroba (2s. 9d. per lb.). This woke up the people from their apathy, and the impulse once given, extended so rapidly and widely 
that, nearly throughout the Amazon and its principal tributaries, the mass of the population put itself into motion to search out and fabricate Seringa. In the province of Para alone (which now includes a very small portion of the Amazon) it was computed that 25,000 persons were employed in that branch of industry in the year I 854 ."

Ten years ago the export of rubber from Para amounted to 22,544 tons. During the last four years the exports of rubber from the Amazon are estimated by Messrs Figgis, loc. cit., as 30,385 tons in $1904,34,420$ tons in $1905,34,520$ tons in 1906 , and 37,520 in 1907. These figures do not suggest any reduction of supplies from the Amazonian region in the near future; indeed it is the opinion of persons well acquainted with the Amazonian rubber trade that still greater quantities could be collected.

With regard to the principal source of Central American rubber, a recently published consular report states: "The tropical forests of the coast provinces of Ecuador are the native habitat of the rubber tree, Castilloa elastica, and the exportation of the rubber derived therefrom has been now going on for upwards of half a century." Although this report mentions the "wanton destruction of the trees," it quotes the undermentioned figures as the exports of rubber from Ecuador for the years I 897 to 1905 :-

\begin{tabular}{|c|c|c|c|c|c|c|c|}
\hline Year. & & Tons. & Year. & & & & Tons. \\
\hline I 897 & - & 496 & 1902 & - & - & - & $3^{88}$ \\
\hline I 898 & - & 709 & 1903 & - & - & - & 486 \\
\hline I 899 & - & 644 & 1904 & - & - & - & 510 \\
\hline 900 & - & 493 & 1905 & - & - & - & 576 \\
\hline
\end{tabular}

The Mexican rubber shrub (Parthenium argentatum, A. Gray) has contributed considerable quantities of rubber to the United States market during recent years. In 1907 the exports of this rubber, which is known in the trade as Guayule rubber, amounted to about 3,000 tons. It would appear, however, that this source of supply is short lived, for the United States Consul in Mexico City has recently reported that, at the present rate of consumption, there is only sufficient 
material for the large factories for five years and the smaller ones for three years.

The exports of Ceará or Maniçoba rubber, another important South American product, are reported to be increasing. Until the last two or three years it was generally supposed that Manihot Glaziovii, Muell. Arg., furnished this product, but it now transpires that at least three other species of Manihot contribute. Ule ${ }^{*}$ has decided to distinguish the new species as $M$. heptaphylla, $M$. piauhyensis, and $M$. dichotoma; he estimates that the present annual yield of rubber from these three species is 500 tons, 600 tons, and 400 to 500 tons respectively.

African rubber is principally obtained from the west coast and the Congo, which furnished 18,000 tons in $1904,17,500$ tons in $1905,17,200$ tons in 1906 , and 17,000 tons in 1907. Here we find a falling off of 1,000 tons in four years, or an annual decrease of 8 per cent.

The most important rubber-yielding plants in these regions are Funtumia elastica, Stapf, which is a large forest tree, and various creepers belonging to the Natural Order Apocynacex.

Four years ago I was able to point out $\dagger$ that the imports of rubber into the United Kingdom from the British West African colonies, Gambia, Sierra Leone, Gold Coast, and Southern Nigeria, decreased from 4,715 tons in 1898 to 924 tons in 1902 , and that this was largely due to the extirpation of rubber-producing plants by the drastic tapping methods in vogue.

The imports of rubber into the United Kingdom from these four colonies in 1906 were 2,46 I tons, a decrease of nearly 50 per cent. in nine years.

So far as the Congo State is concerned, it would appear that energetic efforts are being made to replace any plants destroyed by ruthless tapping. Regulations now in force stipulate that fifty rubber plants should be planted for every 100 kilos. of rubber extracted. H.B.M. Consul reports: "The rubber plantations in the Congo State now contain over ten million plants; of these nine-tenths are vines and the remainder trees, of which the oldest

* "Der Tropenpflanzer," Dec. I907.

+ Reports on rubber in the Gold Coast and Sierra Leone, Colonial Reports, Miscellaneous, I904. 
plants are ten years old, and experiments have shown that the trees and vines are still too young to bleed. The possibilities of extending the plantations are illimitable, and planting continues each year in accordance with laws regulating this industry. In this district, at any rate, there is not likely to be any great fall in production for some time to come."

The reports of rubber from the Congo State only decreased from 6,470 tons in 1903 to 6,309 tons in 1906 . Those from Loanda fell from 950 tons in 1904 to 900 tons in 1907, while those from Benguela and Mossamedes rose during the same period from $\mathrm{I}, 600$ to $\mathrm{I}, 700$ tons.

The French colonies in West Africa increased their exports of rubber from I,I 72 tons in 1895 to 3,918 tons in 1904 , and the German colony of Togoland raised hers from 63.7 tons in I90I to II 5.2 tons in 1905 .

That the rubber trade on the east coast of Africa is increasing will be evident by the exports from the principal producing countries given below :-

\begin{tabular}{|c|c|c|c|c|c|c|c|}
\hline Year. & Zanzibar. & Uganda. & $\begin{array}{l}\text { British } \\
\text { East } \\
\text { Africa. }\end{array}$ & $\begin{array}{l}\text { Nyasa- } \\
\text { land. }\end{array}$ & $\begin{array}{l}\text { Mada- } \\
\text { gascar. }\end{array}$ & Beira. & Total. \\
\hline I 90I & $\begin{array}{l}\text { Tons. } \\
98 . \mathbf{I}\end{array}$ & $\begin{array}{l}\text { Tons. } \\
\ldots\end{array}$ & $\begin{array}{c}\text { Tons. } \\
20.5 \\
\text { (approx.) }\end{array}$ & $\begin{array}{c}\text { Tons. } \\
6.4\end{array}$ & $\begin{array}{l}\text { Tons. } \\
\text { I } 89\end{array}$ & $\begin{array}{l}\text { Tons. } \\
83.0\end{array}$ & $\begin{array}{l}\text { Tons. } \\
397.0\end{array}$ \\
\hline 1902 & I 36.2 & $30.6^{\circ}$ & $\begin{array}{c}3 \mathbf{I} \cdot 3 \\
\text { (approx.) }\end{array}$ & 5.2 & I6I & $6 \mathrm{r} \cdot 3$ & 425.6 \\
\hline 1903 & I 30.6 & 20.5 & 43.3 & 2.0 & 584 & 61.0 & 841.4 \\
\hline 1904 & 132.5 & 23.2 & 81.6 & 7.9 & 865 & 90.5 & $1,200.7$ \\
\hline 1905 & 6o.I & 45.2 & $64 \cdot 3$ & $7 \cdot 7$ & 904 & $97 \cdot 5$ & I, I 78.8 \\
\hline
\end{tabular}

Returns are not available from all the centres of production for a complete review to be furnished, but the preceding statistics sufficiently indicate that there is not likely to be any serious fall in the output of wild rubber in the near future. African sources of supply will certainly show signs of exhaustion before those in tropical America, as they principally consist of widely scattered vines and herbaceous plants, the extraction of rubber from which is exceedingly difficult to supervise and control.

To-day rubber is, however, being collected by far more scientific methods than those originally in vogue, and Admini- 
strators and Concessionaires better appreciate the necessity of checking injurious methods of rubber extraction.

The discovery of new rubber-producing plants is not beyond the bounds of possibility. Recently a small tuberous Asclepiad (Raphionacme utilis, Brown and Stapf), has been found abundantly in Benguela. Tubers examined by the writer proved to be rich in latex from which some excellent samples of rubber were obtained. According to "Der Tropenpflanzer," of December 1907, a new rubber tree has been still more recently discovered in Tonkin which yields latex containing a high percentage of caoutchouc; this latter, when well prepared, compares favourably with Para rubber. The new rubber tree grows from 30 to 45 feet high; it has been identified as a new species of Bleekrodea, a genus of the Natural Order Urticaceæ, and has been described as Bleekrodea tonkinensis, Dub. and Eberh.

\section{Cultivated Rubber.}

As soon as the vast areas planted with rubber-producing plants during the last few years come into bearing the supply of rubber will be considerably augmented. Messrs Ferguson, the well-known compilers of tropical planting statistics, estimated at the beginning of the year the world's cultivated rubber area to be as follows :-

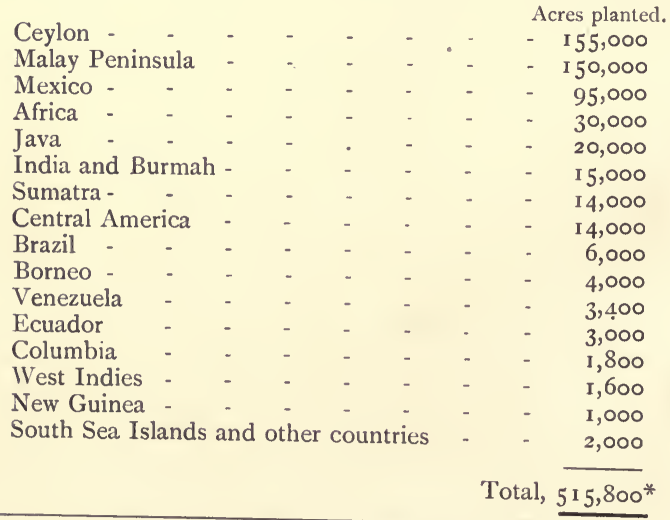

\footnotetext{
"Supplement to the Tropical Agriculturist, Jan. 1908, p. 87.
} 
Without taking into consideration the additional areas planted since this compilation was prepared, let us endeavour to estimate the yield from, say, 500,000 acres. A very large portion of this has been planted with Para trees which, as will be shown later, yield about $\frac{1}{2}$ to I $\mathrm{lb}$. of dry rubber per tree when five or six years old, and this may increase till as much as $25 \mathrm{lbs}$. per tree is produced in one year from old trees. The latter is an exceptionally large return, and must not be taken into consideration for the purposes of the present estimate. The yield from areas not planted with Hevea trees will probably not be so large. Rubber trees are planted at distances varying from to to 40 feet apart. Many trees have already been tapped for several years, and considerable numbers will reach the productive stage in a year or two, while it is estimated that the whole half million acres should be in bearing by the year I9I3. But let us take very conservative figures and assume that we have half a million acres planted with rubber-producing trees, planted at 20 by 20 feet apart, or 109 trees to the acre, that the average yield per tree will be in six years' time, i.e., I9I3, I lb. of rubber per tree, and that the average yield per tree will only increase by $4 \mathrm{oz}$. annually for ten years. Calculated on this basis the world's production of cultivated rubber from our half million acres will be as follows :-

\begin{tabular}{|c|c|c|c|c|c|}
\hline Year. & $\begin{array}{l}\text { Yield of Culti- } \\
\text { vated Rubber. }\end{array}$ & $\begin{array}{c}\text { Average } \\
\text { Yield per } \\
\text { Tree. }\end{array}$ & Year. & $\begin{array}{l}\text { Yield of Culti- } \\
\text { vated Rubber. }\end{array}$ & $\begin{array}{c}\text { Average } \\
\text { Yield per } \\
\text { Tree. }\end{array}$ \\
\hline I9I 3 & $\begin{array}{l}\text { Tons. } \\
24,300\end{array}$ & $\begin{array}{l}\text { Lbs. } \\
1.0\end{array}$ & I9I 8 & $\begin{array}{c}\text { Tons. } \\
54,743\end{array}$ & $\begin{array}{l}\text { Lbs. } \\
2.25\end{array}$ \\
\hline 1914 & 30,4 I 3 & I. 25 & 1919 & 60,825 & 2.5 \\
\hline I9I 5 & $3^{6,495}$ & 1.5 & 1920 & 66,908 & 2.75 \\
\hline 1916 & 42,578 & I. 75 & 1921 & 72,990 & 3.0 \\
\hline I9I 7 & 48,660 & 2.0 & 1922 & 70,073 & 3.25 \\
\hline
\end{tabular}

Far higher returns than those given above have been prophesied. Ferguson* considers that 3 I,000 tons of rubber will be produced in the East from 320,000 acres during the year I9I3, and estimates the following probable exports of rubber from Asia in tons :-

* Supplement, Tropical Agriculturist; p. 66, Sept. 1907. 


\begin{tabular}{|c|c|c|c|c|c|c|c|c|}
\hline & 1906 & 1907 & 1908 & I909 & I9IO & 1911 & 1912 & 1913 \\
\hline \multirow{4}{*}{$\left.\begin{array}{l}\text { Ceylon } \\
\text { Malay } \\
\text { Peninsula }\end{array}\right\}$} & I 50 & 230 & $35^{\circ}$ & 650 & $I, 400$ & 3,100 & 6,000 & I 3,000 \\
\hline & 500 & 800 & I, 100 & 1,500 & 2,500 & 6,000 & 9,000 & I 2,000 \\
\hline & 380 & 400 & $55^{\circ}$ & $75^{\circ}$ & 1,000 & 2,500 & & $6, \infty 00$ \\
\hline & 1,030 & $1,43^{\circ}$ & 2,000 & 2,900 & 4,900 & I 1,600 & I 9, ০০০ & 31,000 \\
\hline
\end{tabular}

Now let us consider what will be the position of the rubber market in I9I 3 and four following years. Assuming that the supplies of wild rubber will be maintained at a figure equal to that which obtained in 1907 , viz., 67,000 tons, that our estimated yield of cultivated rubber be correct, and the annual rate of increase of consumption be 5 per cent., we get the following :-

\begin{tabular}{|c|c|c|}
\hline Year. & $\begin{array}{c}\text { Estimated Supply } \\
\text { of Wild and Cult- } \\
\text { vated Rubber. }\end{array}$ & $\begin{array}{c}\text { Estimated } \\
\text { Consumption. }\end{array}$ \\
\hline & Tons. & Tons. \\
I9 I 3 & 91,330 & 84,235 \\
I9I4 & 97,4 I 3 & 88,446 \\
19I5 & I03,495 & 92,869 \\
I9I6 & I 09,578 & 97,5 I 2 \\
I9I7 & I I 5,660 & I02,388 \\
\hline
\end{tabular}

It will thus be seen that notwithstanding our extremely moderate estimate of yield of cultivated rubber in I9I3, the estimated supply is more than 7,000 tons in excess of the estimated demand. Actually this excess is greater, for the wild rubber, which has practically supplied the market up to date, contains from 15 to 20 per cent. more impurities than Para plantation rubber; or in other words, 20,000 tons of cultivated rubber are equivalent to about 23,530 tons of wild rubber. Unless consumption increases at a greater rate than that which has obtained during recent years, a keen struggle between producers of wild and cultivated rubber is evidently imminent, and a fall in prices will be the inevitable result. It is argued by 
many that the latter contingency would materially benefit the rubber industry, as rubber could then be largely employed in the manufacture of numerous articles for which its present high price renders its use prohibitive. Floor-tiling and paving are two striking examples of the uses for which rubber may be extensively employed in the future. It has been repeatedly demonstrated that for these purposes rubber is far more durable than wood, stone, or asphalt. With reference to a paper* read before the Royal Society of Arts, Mr W. R. Broadbent wrote: $†$ -

"The authors of the above paper state on page 379 of the Journal that only steel-covered roads would stand the wear of the new studded tyre with projecting steel studs. I wish to point out that a road composed of rubber blocks or some form of gutta-percha would stand the wear for a considerable time, but, as $\mathrm{Mr} \mathrm{P}$. J. Thomas remarks in the discussion, it is mostly a matter of $£$ s. d. If it were not so, I should consider that for town use, in place of the present wooden blocks, some kind of rubber, gutta-percha, or substitute in the form of blocks or thick sheets, would solve the problem of road covering, rubber being noiseless, waterproof, pliable, and cleanly; also having rubber to rubber in the case of motor cars. The question, of course, of the first cost of such an undertaking makes it utterly out of the question."

Many planters affirm that under existing conditions they can bring rubber trees to the producing stage for from $£_{30}$ to $£ 35$ per acre, and place the rubber on the market for from Is. to Is. $6 \mathrm{~d}$. per $1 \mathrm{~b}$.

In 1907 the accounts of one rubber-planting company operating in the Federated Malay States showed that the cost of delivering rubber in Colombo amounted to about 2s. per $1 \mathrm{~b}$. Doubts have been expressed in regard to the possibility of the rubber planter's keenest rival in the Amazon being able to compete with him in the event of a serious permanent fall in price, in view of the high cost of collection and heavy export dues obtaining in that country. It is, however, only reasonable to suppose that the Brazilian Government would prefer to reduce their export duties rather than damn their rubber industry. Long established institutions, such as the Brazilian rubber industry, die hard, and although a permanent fall in price would

* Journal of the Royal Society of Arts, No. 2884, vol. lvi.

+ Ibid., No. 2885 , vol. Ivi. 
undoubtedly diminish the output there would still be a keen competition between wild Brazilian and cultivated rubber for many years. The inferior grades of rubber, such as many of those received from Africa, would possibly be the first to feel the struggle. Those persons acquainted with the small cost at which many of these are obtained locally, and with the endeavours now being made to improve their quality by adopting better methods of collection and preparation, will appreciate the difficulty which the rubber planter will be likely to experience in substituting his products for these grades. Vice-Consul Armstrong has shown, in regard to the cost of collecting Congo rubber, that in one district the natives are paid only 50 cents. (5d.) per kilo, administration expenses being estimated to increase this cost to I franc per kilo., while he considers that transport expenses cannot be more than 2 francs per kilo.- - a total cost of 3 francs per kilo., or about Is. 2d. per lb. Rubber from Landolphia Kirkii, the commonest rubber-bearing liana in East Africa, which often realises prices only $I d$. to $2 d$. per $1 b$. less than fine Para, can be collected in East Africa under equally favourable conditions.

Some manufacturers still view cultivated rubber with suspicion. Those who have erected expensive plant for the express purpose of purifying the lower grades of rubber will obviously not be anxious to purchase washed plantation rubber. Many of the processes now in vogue for dealing with wild rubber have only been elaborated after a large number of years of careful experimenting, and it is not surprising that the new forms of rubber are looked at with a certain amount of disfavour by manufacturers.

Before closing this chapter a few words are necessary concerning three most important factors likely to affect the rubber industry, viz., shortage and increased cost of labour, epidemics, and the discovery of artificial or synthetic rubber.

\section{LABOUR.}

The labour problem is already commencing to cause anxiety to rubber planters in the East. The report of the Ceylon Planters' Association for the year 1907 states in regard to rubber: "The growth of the trees is good, and the estates are generally in 
satisfactory order, though in some localities scarcity of labour has caused weeding of new clearings to be both difficult and expensive." In Malaya, this question is, however, more serious. Enormous planting schemes have been started within the last few years which are dependent to a very great extent on indentured labour for development. The Director of Agriculture for the Federated Malay States in his annual report for 1906 gave the number of labourers employed on estates at nearly 40,000, of whom about 30,000 were Tamils, and estimated that when the thirteen million trees then planted come into bearing in five years' time, 50,000 coolies will be required for tapping operations.

Rates of wages have consequently increased, with the natural result, an enhanced cost in the production of rubber.

If labour be scarce in the planting districts now that only about two million trees are in bearing, what will be the condition of affairs six years hence, when it is estimated that over fifty million trees will have reached the productive stage? Tamil labourers engaged in South India are largely employed both in Ceylon and in Malaya, and it is a significant fact that several estates in South India have recently increased their rate of pay for Tamil labour.

The bulk of the cultivated rubber areas are sufficiently distant from the most important centres of wild rubber production for any shortage of labour, caused by the development of the cultivated rubber industry, to injuriously affect the collection of wild rubber.

\section{EPIDEMICS.}

The cultivation of large areas with a single species of plant is always a dangerous policy in view of the difficulty of checking the diffusion of diseases. Notwithstanding the comparative immunity from diseases which cultivated Para rubber plants have so far experienced, the fact must not be lost sight of that the constant stripping of the bark of the trees, which modern methods of tapping involve, and the constant weakening of the trees renders them more susceptible to both insect and fungus attacks. Where rubber plants exist in the wild state intermingled with a vast variety of different orders, genera, and species of plants, their isolation prevents the spread of noxious diseases to a very large extent. 


\section{Artificial or Synthetic Rubber.}

The possible profitable production of synthetic rubber has now been an incubus to the rubber producer for over sixty years, and appears to be as far off materialisation as ever it was. The records at the Patent Office show that more than three hundred inventions of rubber substitutes have been filed. Tilden's reported manufacture of synthetic rubber in 1882 from isoprene has since been questioned by Harries, who has shown that the constitution of rubber renders its manufacture from isoprene improbable. Isoprene may be separated from the oil of turpentine and also from colza, castor, and linseed oils. Isoprene is colourless, but if it be exposed to the light for several months its consistency changes to a syrupy nature in which yellow matter resembling rubber may be observed. This has been determined by certain scientists to be synthetic rubber. Rubber substitutes have for years been manufactured from the seeds of poppy, rape, castor, and flax, for the express purpose of mixing with crude rubber in the manufacture of various rubber goods, and new substances suitable for that purpose are being constantly discovered. These form the bases of the majority of the socalled synthetic rubber discoveries, but which are in reality rubber substitutes mixed with crude rubber.

Rubber consists of very complicated compounds of proteins, resins, and caoutchouc, the exact chemical composition of which is not yet thoroughly understood by chemists ; it is consequently improbable that synthetic rubber will be commercially manufactured until these problems have been more satisfactorily solved. Chemists who have devoted considerable attention to the study of rubber still speak dubiously of the probability of the profitable manufacture of synthetic rubber on a large commercial scale.

Synthetic rubber, to compete favourably with Para rubber, must possess not only all its chemical constituents but, in addition, all the valuable physical properties for which Para rubber is so much esteemed. 


\section{CHAPTER III.}

THE PARA RUBBER TREE AT HOME AND ABROAD.

THE Para rubber tree (Hevea brasiliensis) is indigenous to the forests of the Amazon valley and neighbouring districts, where it is said to grow to a height of about 60 feet, with a trunk of some 6 feet in circumference. The leaves of the tree are trifid, the leaflets elliptical lanceolate. The flowers are unisexual, small, green, and sweetly scented, produced in panicles, the female flowers being larger than the male flowers and frequently terminal. The fruit consists of a capsule, divided into three divisions, one seed in each division. The fruits burst spontaneously when ripe, and the seeds are often dispersed as far as 50 or 60 feet from the tree. The seeds are about an inch long, flat on one side and round on the other, with a shiny brown testa mottled with darker blotches. The kernel of the seed is very oleaginous, and could be remuneratively employed for oil manufacture, the oil which it produces being very similar to linseed oil. (See Chapter XV.)

In order to judge of the climatic requirements for the successful cultivation of this tree, it will be advisable to review the conditions obtaining in its native habitat, and in some of the countries where it has been introduced and successfully cultivated.

The province of Para, from which the product of this tree derives its name, is situated south latitude $I^{\circ}$. It is reputed to enjoy a remarkably uniform climate with a mean temperature of $8 \mathrm{I}^{\circ}$ Fahr., a very moist atmosphere, and an annual rainfall varying between 60 and 90 inches.

In Ceylon the Para tree has been successfully cultivated since its first introduction more than a quarter of a century ago. I have seen it growing vigorously in Ceylon at all elevations up to 3,000 feet, and where the rainfall varied from 70 to 150 inches per annum. Mr Stanley Arden, Ex-Superintendent, Experimental Plantations, Federated Malay States, reports: "Hevea 
brasiliensis is admirably suited to the conditions obtaining in the Malay Peninsula and adjoining islands, and its cultivation here is a comparatively easy matter. From reports to hand, it would appear that this tree naturally affects swampy places, but here it thrives in any locality at low elevations, and on almost any kind of soil."

Except near the mountains, the rainfall in this country is about 90 inches per annum, and there is no well marked dry season. The general mean temperature is about $80^{\circ} \mathrm{Fahr}$.

In the Gold Coast, West Africa, this tree, grown in experimental plots in the Botanic Garden, Aburi, which is situate I,500 feet above sea-level, and where the average mean temperature is about $8 \mathrm{I} .5^{\circ} \mathrm{Fahr}$. and the annual average rainfall 47 inches, promises better results than any other rubber-producing plant, indigenous or exotic. It is likewise favourably reported upon in India, Jamaica, Dominica, St Vincent, Grenada, Trinidad, Zanzibar, Uganda Protectorate, Borneo, Java, and Mozambique.

The manner in which this tree has adapted itself to the various climatic conditions obtaining in the different countries above mentioned is almost unique in tropical cultivation.

The tree grows rapidly under cultivation.

Trees on an estate in Selangor grew to a height of over 30 feet with a girth of 19 inches in four years.*

The original trees, planted at Heneratgoda (Ceylon) in I876, were about 30 feet high and 14 inches in girth two years later. In I 882 the largest tree was 50 feet high, and 25 inches in girth at a yard from the ground. The girth of this largest tree was taken annually after this, with the following results :-

"It was 30 inches in 1883,36 in 1884,43 in 1885,49 in 1886 , $53 \frac{1}{2}$ in 1887,60 in 1888,65 in $1889,69 \frac{3}{4}$ in 1890,73 in 1891 , and $79 \frac{1}{2}$ in $1893 . "$

Mr Derry, Superintendent, Government Plantations, Perak, writes that an eighteen-year-old tree growing at Kuala, Kangsar, has a girth of 8 feet 6 inches at 3 feet from the ground.

Trees planted on moist land in the Congo grew 16 feet high in two years.

Ten trees planted in Cachar, North-East India, amongst tea

* Agricultural Bulletin of the Straits and Federated Malay States, June 1902.

+ Circular, Royal Botanic Gardens, Ceylon, Jan. I898. 


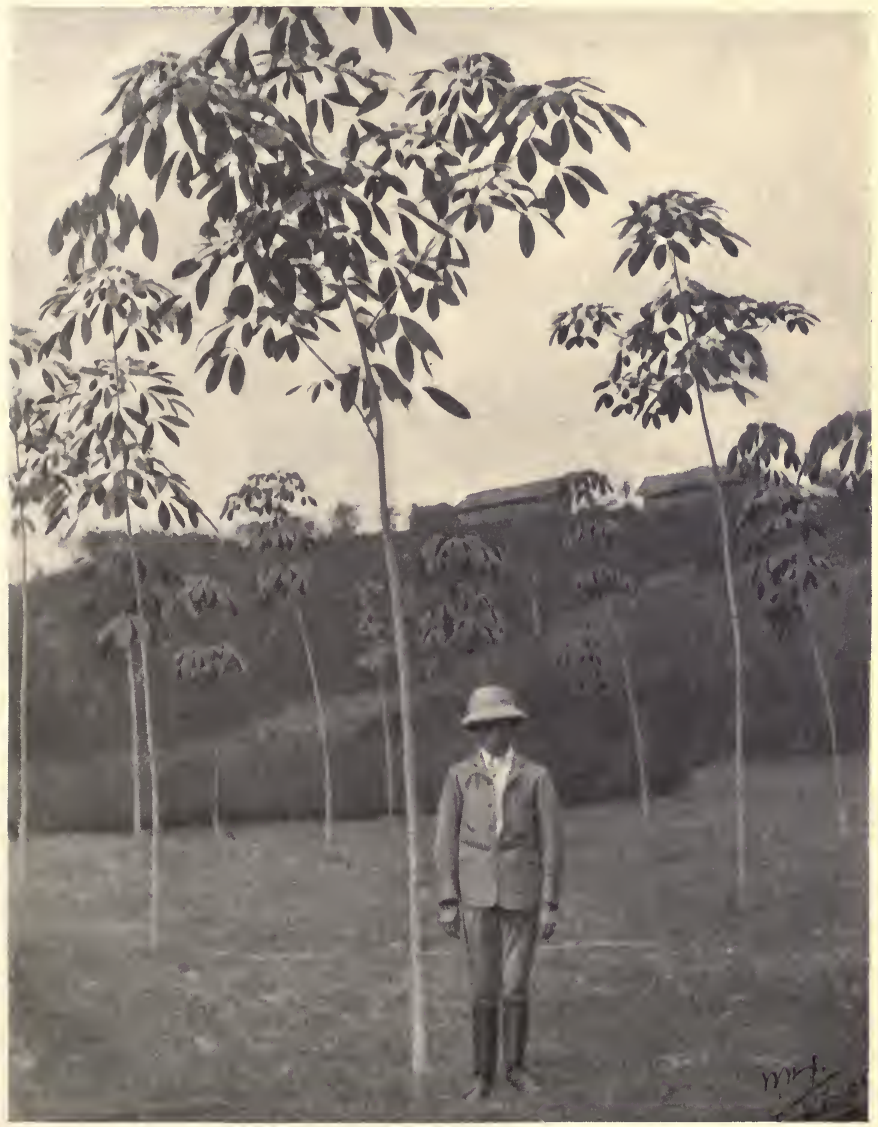

FIG. 3.-Para rubber trees planted in the Tarkwa Botanic Station, Gold Coast, West Africa, in June 1904. (Photographed by Author in December 1905.) 

in the year I897, were tapped during the season December to March 1906-7 and yielded Io lbs. of rubber.*

A Para tree in Uganda had produced a trunk with a girth of I $2 \frac{1}{2}$ inches at 4 feet from the ground, and had grown $27 \frac{1}{2}$ feet high when four and a half years of age. Some 200 trees in the same country have grown 17 feet high in two and a quarter years. The Acting Director of Agriculture in the Gold Coast estimated that the Para trees planted in the Aburi Botanic Gardens in that colony in the year 1900 would be ready for tapping during $1907 .+$

Measurements taken of trees in the Tarkwa Botanic Station, Gold Coast, in December I906, are given below :-

\begin{tabular}{|c|c|c|c|c|c|c|}
\hline \multirow{2}{*}{ Plot No. } & \multirow{2}{*}{$\begin{array}{l}\text { Date of } \\
\text { Planting. }\end{array}$} & \multirow{2}{*}{$\begin{array}{c}\text { Distance } \\
\text { Trees Planted } \\
\text { Apart. }\end{array}$} & \multicolumn{2}{|c|}{ Height. } & \multicolumn{2}{|c|}{$\begin{array}{l}\text { Girth at } 3 \mathrm{ft} \text {. from } \\
\text { the Ground. }\end{array}$} \\
\hline & & & Dec. I905. & Dec. I906. & Dec. I905. & Dec. I906. \\
\hline & & Feet. & Feet. & Feet. & Inches. & Inches. \\
\hline 1. & June i904 & $15 \times 15$ & 20 & 28 & 7 & 12 \\
\hline II. & " & I $2 \times 12$ & I 6 & 25 & 6 & 10 \\
\hline III. & July & $15 \times 15-$ & I 4 & 24 & 6 & 10 \\
\hline IV. & ", & $20 \times 20$ & I 4 & 25 & 6 & I I \\
\hline V. & & $30 \times 30$ & 12 & 27 & 4 & 9 \\
\hline VI. & $"$ & $40 \times 40$ & I 2 & 27 & 4 & 9 \\
\hline VII. & " " " & $12 \times 12$ & 12 & 26 & 4 & 9 \\
\hline VIII. & $\left\{\begin{array}{l}\text { Aug. and } \\
\text { Sept. I } 904\end{array}\right.$ & $12 \times 12$ & I 2 & 27 & 4 & 10 \\
\hline
\end{tabular}

An illustration of eighteen-month-old trees, growing in this station, is given (Fig. 3 ).

The Director of Agriculture for the Federated Malay States quotes the average growth in that country as 3 to 9 inches girth in two years, Io to 30 inches girth in four to six years, and 30 to 60 inches in seven to ten years. Planters conversant with both Ceylon and Malaya affirm that in the latter country trees arrive at the productive stage at least one year earlier than in Ceylon; this more rapid growth is attributed to the virgin soil on most of the estates and not to any climatic advantage.

* Agricultural Journal, India, July 1907.

+ Annual Report, Botanical and Agricultural Department, Gold Coast, 1906. 


\section{CHAPTER IV.}

\section{PROPAGATION.}

THE tree may be propagated either by seeds or cuttings, but the former is the more expeditious method. Great care should be exercised in selecting the seeds, as they rapidly lose their vitality; it is therefore advisable to sow them as soon as possible after they have ripened. A fairly large proportion will, however, survive a long journey. From 500 seeds supplied by a Ceylon seedsman to the Gold Coast Botanical Department in November 1900, 200 plants were raised. These seeds were packed with powdered charcoal in tins, and were over two months in transit.

An experiment was carried out by the Gold Coast Botanical Department, with a view to ascertain the better method for packing seeds sent from the Orient to West Africa, viz., packed with moist soil in Wardian cases or with charcoal and sawdust in ordinary boxes: 20,000 seeds packed by the first-mentioned method at the Royal Botanic Gardens, Ceylon, arrived at the Tarkwa Botanic Station, Gold Coast, in November 1903, and from these, 3,400 plants have been raised; while from 30,000 seeds packed with charcoal and sawdust in ordinary cases, sent at the same time, 3,650 plants have been raised.

The Wardian cases were, however, opened and their contents watered upon their arrival at Liverpool, and then again closed up and forwarded. Although the percentage of seeds which survived the journey in Wardian cases was higher than that of those in the boxes, it by no means compensated for the extra expenses incurred, as about 3,000 seeds were packed in each IVardian case, and 10,000 in each box. A Wardian case costs $£ \mathrm{I}$, as against two or three shillings for an ordinary packing case. Ninety-five per cent. of some seeds germinated which had been sent from Ceylon through the post in canvas bags to the Royal Botanic Gardens, Kew.

Mr J. C. Harvey, writing from Mexico to the editor of the Straits Settlements Agricultural Bulletin, states: "You will perhaps be interested to know that of the twenty seeds of Hevea 
brasiliensis you so kindly sent me, I have now fourteen thrifty plants a foot high. I feel very proud of them. The matter is worthy of record, as undoubtedly they are the first plants ever raised in Mexico."

These seeds left Singapore on the I 2 th February 1903, and arrived in Mexico on 3rd May 1903, and were therefore about three months in transit.

\section{Seed Selection.}

Too great care cannot be taken in selecting good seed, for the whole life of the plant depends upon the seed. Its selection for rubber planting is of far greater importance than in the case of annual crops, where the sowing of poor seed in any one season may generally be remedied the following year. With rubber a good many years must elapse before the results are visible.

Endeavour to select seeds from healthy, prolific trees, especially those with a naturally sturdy trunk and many branched crown, as these invariably afford the best tapping areas and are less liable to be broken by wind. A well-developed trunk is of primary importance. It is the most accessible portion of the tree for tapping, so that the greater area of bark available in this region the better.

The yield of rubber from different trees growing under similar conditions in the same plantation varies to an enormous extent. Vernet conducted experiments with a view to compare the yield of different trees and to determine the percentage of caoutchouc in the latex obtained from them. He published the following results :-*

\begin{tabular}{|c|c|c|c|}
\hline No. of Tree. & $\begin{array}{l}\text { Volume of } \\
\text { Latex } \\
\text { Obtained. }\end{array}$ & $\begin{array}{l}\text { Percentage of } \\
\text { Caoutchouc } \\
\text { in the Latex. }\end{array}$ & $\begin{array}{c}\text { 1)ry Rubber } \\
\text { per Tree. }\end{array}$ \\
\hline Io & C. C. & 30.74 & Grs. \\
\hline I I & I 5 & 30.16 & 4,524 \\
\hline I 2 & 20 & $39.4 \mathrm{I}$ & 10,998 \\
\hline 13 & I 6 & 31.20 & 4,492 \\
\hline I 4 & 4 & $3^{2.17}$ & I, 286 \\
\hline I5 & I 2 & 29.23 & 3,570 \\
\hline I 8 & 48 & $29.5 \mathrm{I}$ & 14,164 \\
\hline
\end{tabular}

* Journal d'Agriculture Tropicale, July I907. 
Large heavy seeds invariably give better_results than small light ones.

When purchasing seeds obtain them from growers who make a practice of seed selection, and adopt scientific methods of cultivation and disease prevention, as such seed must necessarily prove more satisfactory than that from careless growers. Seed which has to travel long distances should be packed with dry material and preferably with powdered charcoal. The seed and packing material should be placed in layers with sheets of stout paper or some similar substance between each layer to prevent the powdered charcoal, or whatever is used in its stead, working out from between the seeds in transit.

\section{SEed Sowing.}

The seeds may either be raised in seed beds, singly in bamboo pots, or directly in the situations it is intended the trees shall occupy in the plantation.

When seeds are scarce, sowing them in bamboo pots or baskets is perhaps most satisfactory, for by this method the roots of the plants are not as much disturbed when they are transferred to the plantation as is the case when they are lifted from nursery beds. While, if seeds be sown out direct in the plantation, and a spell of dry weather follows, a large number will fail to germinate. When large numbers of plants are to be raised, it is advisable to select a well-sheltered spot possessing a rich, light, friable soil and near the site for the plantation. On this temporary nursery shelters should be constructed by fixing stout upright posts about 8 feet high, in lines Io feet apart each way, and then on these cross bars, the whole sufficiently strong to support a thin layer of palm leaves, split bamboos, or some similar material. Under this the bamboo pots or baskets should be placed. If it be decided to sow the seeds in beds, these should be made 8 feet wide, i.e., one bed between each row of posts, and allow the intervening spaces to serve as paths in order to facilitate the work of watering and weeding the beds. It will be found that under such a shelter the work of watering will be considerably lessened, and when germination takes place the young seedlings will be protected from heavy rains and scorching sun. The beds should be thoroughly dug up to a depth of about 
12 inches. The distance apart to sow the seeds in the beds must depend upon the quality of the seed and the length of time the plants have to remain in the nurseries.

It is safe to transplant the young plants when they are from I $\frac{1}{2}$ to 2 feet high. If this be the object in view, rows could be made I foot distant, and the seeds sown in them about 9 inches apart. The seeds should be sown about I inch below the soil, and the seed beds or pots kept thoroughly and regularly watered. Regular watering does not imply that the beds are to be watered every day, but that they are to be watered when they require it, or when the surface becomes dry.

Young plants need protection from animals, . which will eat them greedily. A few days previous to transplanting the young trees, the shading materials should be removed from the shelters in order to accustom the plants to the direct rays of the sun, or what is known in England as "hardening off the plants."

Seeds may be obtained from Ceylon or the Straits Settlements at about $6 \mathrm{~s}$. 8 d. per $\mathrm{I}, 000$. In each of these colonies they ripen in July and August, but they can be obtained through any leading European seedsman.

Bamboo pots are manufactured by sawing up bamboo poles into sections about I foot long. The bottom of the pot is formed by sawing one end off about an inch below an internode or division of the pole, a hole being made in the division to allow water to drain away. A few rough stones should be placed over the hole to prevent fine soil filtering through, and the pot filled to within 2 inches of the top with light friable soil. Providing the vitality of the seed be good, one seed is sufficient to sow in each pot, and this should be placed on the soil in the pots prepared in the manner above described, and then covered with about an inch of soil.

After the seeds germinate, and the pots become filled with roots, more frequent waterings will be necessary. If the plants suffer for lack of water at this period, they are liable to receive a severe shock to their proper development.

In the Malay Peninsula, the usual plan is to germinate the seed in nurseries, and when the plants are about 5 or 6 feet high to cut them down to within 6 inches or a foot of the ground, the stumps being then planted out in the plantation in 
prepared holes. It is, however, very obvious that this procedure must check the plant's growth considerably.

At several of the large estates that I visited in Ceylon, it was considered the best plan to sow the seed out in the open plantation, i.e., in the positions it was intended the trees were to remain. This system is called "sowing to stake." At one estate I saw trees grown from seeds sown to stake in I898 which had developed sufficiently to be tapped at the end of 1902.

No doubt this method has much to recommend it, providing the seeds can be sown during a season when the soil is kept constantly moist by frequent rains, as the Para tree sends down a long tap-root which is often broken when young plants are transferred from the nursery beds to the plantation. But it is much more difficult to protect young plants in the open field from animal attacks than it is in the nurseries.

If seeds be abundant, seven or eight should be sown in each stand and when these germinate, all weakly, backward, or badly formed plants should be thinned out and destroyed, leaving two or three of the most promising. To conserve moisture in the soil the seed stands should either be mulched with some light material such as grass, or a small framework of palm leaves should be erected over them till the plants are well established. When the selected plants are about a foot high all but the best plant in each stand should be rooted up and destroyed. A supply of seeds should be reserved or a number of plants raised in bamboo pots or baskets to supply vacancies.

Fig. 4 shows some Para rubber seedlings, six months old, growing in a nursery near Beira, East Africa.

\section{Propagating Young Growths.}

It is somewhat surprising that some difficulty appears to have been experienced in propagating Heveas from cuttings during recent years. Large numbers of plants were raised by cuttings taken from the original seedlings brought by Cross from South America in 1876 , and also from the first stock of plants received in Ceylon. The 1906 Annual Report of the Ceylon Botanical Department states with reference to an experiment conducted at Peradeniya to raise plants from cuttings, 
that: "The net result was that at the end of the year not a single plant was obtained from the 3,000 cuttings." A planter in Ceylon has raised several trees from cuttings, and the Tropical Agriculturist for October 1907 gives illustrations of two of them. According to the same journal for November 1907 success has been obtained in Java by "marcotting." In view of the abundance of seeds available it is unnecessary under ordinary conditions to trouble about raising plants from cuttings or by

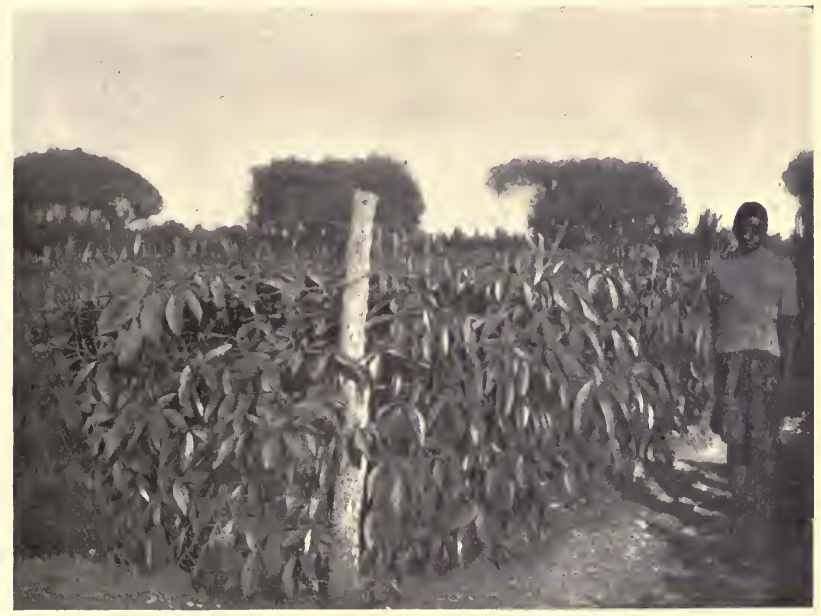

FIG. 4.-Para Rubber Seedlings, six months old, in a nursery on the GuaraGuara Co.'s estate near Beira, East Africa. (Photographed by Author in April 1908.)

"marcotting." But if it be desired to raise plants from any particular tree or variety which produces superior rubber or larger quantities of rubber than its fellows, or possesses any other characteristics which make it desirable for the planter to propagate it, no safer method can be adopted to ensure that the progeny possess the coveted characters than by raising plants from young growths. Unless a flower be protected, crossfertilisation may occur. Even if this be done, the characters of 
any particular variety are not necessarily "fixed" in the plants raised from seeds collected from it.

"Marcotting" is commonly employed by horticulturists when they wish to perpetuate any particular variety of plant which may be difficult to propagate from cuttings. A promising young growth having been selected, a ring of bark is taken off the stem immediately beneath a node or leaf scar, or the stem may be partially severed at this point with a sharp knife. Moist moss or some similar material is then bound round the cut portion and the bandage kept constantly moist until roots are produced; it may then be severed from its parent and transplanted.

When propagation by cuttings is resorted to, young growths about one foot long will be found to give the best results. The base of the cutting should be cut off with a sharp knife just below a leaf or leaf scar, and inserted firmly in the ground. The cuttings require to be shaded and watered regularly.

Whichever method of propagation be resorted to, it is important to bear in mind that the amount of care bestowed on the young plants will materially affect the after-life of the trees. When badly grown seedlings are planted out in the plantation, they never grow so satisfactorily as strong healthy ones do.

Seedlings when too heavily shaded, or crowded too closely together in the nurseries, usually grow into sickly, drawn specimens.

The young seedlings in the nurseries are greatly benefited by being syringed two or three times a day during hot weather. And this also tends to free them of green-fly, which is sometimes very troublesome.

Applications of cow-dung to young plants in the Straits Settlements have proved beneficial in stimulating growth. 


\section{CHAPTER V. \\ PLANTING AND CULTIVATING.}

Site for Plantation.

AT one time it was considered absolutely essential to plant the Para rubber tree in swampy land to grow it successfully, in consequence of the reports of travellers that it was only to be found growing in such situations in its native habitat. This theory, has, however, been proved to be untenable, and many failures have been experienced by planters who endeavoured to cultivate the tree under these conditions.

It thrives best on damp, low-lying lands composed of deep, rich alluvial soil, but it will grow satisfactorily on others. As previously stated, I have seen it growing vigorously in Ceylon at elevations varying from a few feet to nearly 3,000 feet above sea-level, and where the annual rainfall varied from 70 to I 50 inches.

$\mathrm{Mr}$ Francis Holloway, of Kepitigalla, Matale, Ceylon, writing in reply to an inquiry whether Para rubber would be profitable if grown at an elevation of 1,600 to 1,800 feet, says:-**

"I am now tapping some trees at about 1,600 feet on a hillside, and am very pleased with the excellent results obtained. Trees at this elevation, although a good deal smaller than the ones of the same age at a lower elevation, are now being proved to yield better than those lower down. They only require one incision in the morning, and the cups are emptied at II a.m. and replaced under the same cut immediately, and are again emptied at 3 p.m., thus giving the same yield from one cut as would be obtained from two cuts on trees at the lower elevation. I have never been able to do this at the low elevation, as the latex does not flow at Io a.m. This is proof positive that Para rubber yields better at $\mathrm{I}, 600$ feet than at 600 feet. I think this 
a very important fact, and one that will no doubt be noted by all concerned in Para. It is probably due to the colder atmosphere at the higher elevation, which does not tend to coagulate the pure latex as it exudes from the wound, whereas at a lower elevation the temperature being much higher, the latex scarcely has time to run into the cups before it coagulates on the way, owing to the heat."

Mr Stanley Arden writes :-*

"Nothing could succeed better than this tree does in the Federated Malay States, planted on newly-cleared, well-drained land; and although it is often stated that partial shade, swampy places, and other conditions are essential to success, given a climate with a uniform temperature of about $90^{\circ}$ Fahr., and a large rainfall equally distributed throughout the year, the conditions laid down above are eminently suitable. So far as I can judge it does not appear that the nature of the soil affects either the quantity or the quality of the latex (milk), but in any case it is advisable to plant on a fairly rich soil, a loamy soil for preference, as under such circumstances the tree would grow quicker and stronger, and probably give a return at a younger age than if grown on land deficient in the necessary constituents of plant life."

Some trees in the Botanic Gardens, Aburi, Gold Coast, situated about 1,500 feet above sea-level, are flourishing in comparatively poor stony soil. Although the tree appears to grow in comparatively poor soil in the tropics where the rainfall is sufficient, it does not grow so vigorously on stiff clayey or on dry stony lands as on moist low-lying alluvial lands.

The 1897 report upon the Government Para Plantations in Ceylon states: "The land at certain periods of the year was subject to floods. It was found, however, that these periodical inundations were harmful, and that plants below flood level were destroyed, notwithstanding much attention having been paid to the supplying of vacancies. By this loss about onefourth of the plantation was destroyed, but of the remainder above high-water mark I cannot speak too highly."

Wickham, one of the first investigators of the Para rubber tree in its native habitat, states that, "near the rivers the Para

* Report on Hevea brasiliensis in the Malay Peninsula, 1902. 
trees have a poor growth as compared with those in the highlands, where they are found with a circumference of 10 to I2 feet"; also "the true forests of the natural Para rubber tree lie back on the highlands. As a matter of fact, the whole of the Hevea brought out of the forest by me for the Government of India were from large grown trees found in the forest covering the broad plateau dividing the Tapajos from the Madeira River."

In the Federated Malay States it is grown up to 2,500 feet. 3,000 feet is not considered the maximum altitude at which it may be profitably grown in Southern India, high-class rubber having been produced at 3,000 feet where the rainfall is only about 45 inches per annum.

The writer has seen the foliage of Para rubber trees, in both East and West Africa, looking fresh and green when such plants as coffee, cocoa, and cotton were drooping and losing their leaves because of drought. There is reason to believe that this tree could be profitably grown under irrigation in much drier regions than those in which it is now extensively cultivated. An interesting plantation of this nature is now making satisfactory progress on the property of the Guara Guara and Massanzane Estates Company, on the banks of the Buzi River, East Africa.

Estates at high elevations in Ceylon almost invariably produce cinchona bark richer in alkaloid, finer coffee berries, and better flavoured tea than estates in the low country of that island. In the open competition for Para "biscuit" rubber at the Ceylon Rubber Exhibition, held in September 1906, "biscuits" produced by ten-year-old trees on the Duckwari Estate, which is situated 2,600 to 3,000 feet above sea-level, carried off the prize.

\section{Plotting out the Estate.}

To facilitate the keeping of records, inspection, and for reference purposes, it will be found convenient to divide up the newly cleared estate into rectangular, preferably square, blocks. Ten acres is a suitable area for each block. If the estate has been surveyed, the longest boundary line may be used as a base line, or a base line may be taken right through the centre of the estate. Commencing at one end of the base line put in pegs at 
Io chains apart. Through these run lines at right angles to the base line, then starting from the latter put in pegs at ro chains apart on the lines at right angles to the base. Each peg will then mark the corner of a square block approximately Io acres in area, and these points may be permanently fixed by planting on them a particular tree or shrub on which the number of the block might be marked. If each of these blocks be numbered in rotation it should be possible to refer to a particular line of trees in any block by mentioning the block and the number of the line in the block counting from a specified direction; a particular tree may be similarly indicated. Having demarcated the estate in this manner an accurate plan of it may be easily prepared and the position of roads, drains, streams, and hills clearly defined. By adopting this system a uniformly laid out estate will be obtained, and the allotting and controlling of taskwork, such as tapping, will be considerably facilitated. The area of the blocks may be varied from 5, 1 5, to 20 acres by fixing points on the lines running at right angles to the base at 5, I 5 , or 20 chains apart respectively.

\section{Distance Apart to Plant Trees.}

The distance apart at which trees are planted varies considerably in different plantations. In 1902 the commonest distance at which Hevea trees were planted in Ceylon was 12 feet by 12 feet ( 302 to the acre), where no othèr crops were grown in conjunction, and 40 feet by 40 feet ( 27 to the acre) when planted amongst tea. At the same period planters in the Straits Settlements were planting their trees at distances varying between 10 feet by Io feet ( 435 to the acre) and 36 feet by 36 feet ( 33 to the acre). Many of the more recently formed estates have their trees planted at far wider distance apart than the majority of the old plantations. The latter were established with the idea of subsequently thinning out alternate trees by tapping them to death, but the execution of this policy has been the exception rather than the rule. The immense vitality of the Para rubber tree prevents the tapping to death method from being expeditiously effected. It is extremely doubtful whether it is a wise plan to depauperate trees in this manner, as in this condition they are far more susceptible to disease, and consequently en- 
courage the spreading of an epidemic to the whole plantation. I saw trees in Ceylon, aged about ten years, planted 40 feet apart, with their branches touching. It must, however, be borne in mind that Para rubber tree cultivation is in its infancy, and the proper distance to plant the trees apart is a matter which will require experience extending over a long period to settle satisfactorily. When permanent between-crops are not planted, probably the best results will be obtained by planting fairly closely, say from I 5 feet by 15 to 20 feet by 20 apart, i.e., 193 and 109 trees per acre respectively, and afterwards thinning out weakly trees as they become crowded. One distinct advantage gained by close planting is that it tends to keep weeds down. The extent to which thinning may have to be carried out will be better appreciated when we bear in mind that cultivated trees have grown to a height of nearly 100 feet with a girth of over IOO inches in thirty years. Again, where trees are planted fairly closely together, a much larger yield will be obtained during say the seventh to tenth years following the establishment of the plantation than when planted farther apart. And provided thinning-out be not delayed, no damage to the remaining trees need necessarily follow.

The very close planting of rubber trees, recommended by some writers in order to encourage them to develop long straight trunks to facilitate the tapping operations, is not essential in the cultivation of the Para rubber tree, for, as will be demonstrated later, it is advisable only to tap about six feet of the lower portion of the trunk of this tree. Every encouragement should therefore be given to it to increase the size of its trunk in girth and to form a sturdy tree.

All things being equal, a large tree will produce more latex than a smaller one of the same age, so that it is imperative that the tree's growth should not be checked by overcrowding, as it is a lover of sun and not of shade.

Close planting produces tall trees, and wide planting sturdy branching trees. This is one of the primary principles of arboriculture. As we wish to encourage the latter habit it is obvious that it would be better to err on the side of wide planting.

All trees, bush, \&c., growing on the land to be planted, should be cut down and burnt before planting commences, and 
the ashes thus produced might with advantage be spread over the ground to serve as a fertiliser.

The land to be planted should be lined, and the holes for the plants dug 18 inches deep and a foot wide, and filled with rich surface soil, in readiness for planting.

\section{TRANSPLANTING.}

Transplanting should be performed, whenever possible, during wet or cloudy weather, as the plant's growth will then be less likely to receive a check than if planted in the hot sunshine. If a spell of dry weather sets in before the young plants have become established, they will require to be watered once or twice a day.

Great care is necessary in lifting the plants from the nursery beds, in order to prevent their young roots being broken. The tree develops a long tap-root, and it is necessary not to damage this in any way, as it is principally by means of this organ that the tree is held firmly in the ground, and by which it absorbs supplies of moisture during dry periods.

-Transplanting is assisted by thoroughly watering the nursery beds immediately beforehand. Young plants transferred from the nursery to the plantation often fail to grow because they have been planted too deeply. It is quite sufficient, when planting them in the plantation, to bury the roots to a similar depth to that to which they had grown in the nursery.

The young trees when first transplanted require carefully shading with palm leaves or some similar material, but when once established, they do not need shade and grow stronger without it.

It should be remembered that the young tender roots play a most important part in procuring nutriment for the plant, consequently as few as possible should be broken. It is impossible to lift a plant from the ground without damaging some of them, but with proper care the damage may be reduced to a minimum. Broken or bruised roots should be cut off clean with a sharp knife and the cut portion dipped in tar or some similarly antiseptic solution. Bruises inflicted on the stem should be painted with some antiseptic, as unhealthy or damaged plants are always more susceptible to fungus and insect attacks. Where plants 
are raised in bamboo pots or baskets there is little danger of damaging the roots, as they may be taken out of these with the ball of earth almost intact.

\section{BetweEn-Crops AND CATCH-Crops.}

The cultivation of between-crops or catch-crops in conjunction with Para rubber is greatly recommended for several reasons, the most important being that it is a fallacious policy for a planter to only invest in one product, especially one of which there is a possibility, however remote, of its market price falling below a figure at which it could be profitably produced. Other potent reasons are that well-chosen crops tend to check the spread of disease, and if a judicious rotation of catch-crops be employed the physical condition of the soil is improved by the constant tillage and weeding which the cultivation of these crops entails.

Crops which are nearly related to Hevea should be avoided as being liable to introduce disease instead of checking its spread, since a specific disease generally confines its attacks to nearly allied species. Cocoa, coffee, and tea may be profitably planted as between-crops but it is considered that they should be substituted by annual or small growing crops in every instance where the rubber is planted at less than 40 feet apart, in view of the rapid growth of Hevea. Its development is the primary consideration and should on no account be interfered with by secondary crops.

The soil and climatic requirements of the Para rubber tree and the cocoa tree are very similar. As shade-trees are generally considered necessary for cocoa, Hevea could be advantageously adopted for this purpose in place of the "Bois immortel" (Erythrina spp.) which yields no commercial product. Due consideration must, however, be given to the fact that the Para rubber tree is not evergreen, and that it usually loses its leaves during the dry season. Where this season is protracted, or excessively hot, dry winds occur at this time of the year, the cocoa would require shade-trees which carry their foliage during this period. Cocoa is usually planted about 15 by 15 feet apart, and the shade-trees 45 by 45 feet apart, so if cocoa were grown in conjunction with Hevea as a shade-tree there would be 193 
and 2 I cocoa and rubber trees respectively per acre. The vacant land between both kinds of trees could be utilised during the first few years for the growing of catch-crops. As cocoa does not come into bearing until it is three or four years old, those planted nearest the Heveas would probably not produce many crops before being starved out by the more rapidly growing rubber trees.

Given suitable soil and climatic conditions, cocoa is not a difficult plant to cultivate, nor is expensive machinery absolutely necessary for the preparation of the crop for market. The demand for cocoa continues to expand. The world's consumption of cocoa for the years 1898 and 1906 was estimated at about 70,000 tons and 140,000 tons respectively, or an increase of 100 per cent. in eight years.

Coffee can also be satisfactorily cultivated as a between-crop with rubber, and it is already largely grown as such in Java, Ceylon, India, and the Malay Peninsula. The Liberian species is best suited to the low country, while the Arabian species grows best in the hills. They require to be planted at 10 by 10 feet apart, and 6 by 6 feet apart respectively.

In Ceylon and India tea is being extensively grown in conjunction with rubber.

There are several crops which can be grown as catch-crops with rubber. Some of the most promising are ground-nuts, tobacco, chillies, and maize. Cotton could also be grown until the rubber trees shade the ground too much.

Ground-nuts are specially recommended in view of their fertilising properties. In the United States a yield of from I,500 to $3,000 \mathrm{lbs}$. of nuts per acre is obtained. In Tropical Africa this yield is rarely obtained, although the nuts produced in the latter country are more valuable, as they contain a greater percentage of oil. There is always a constant demand for this class of oil-seed in the European markets, and good shelled nuts realise on an average $£ 12$. IOs. per ton. The plants make excellent forage for cattle, as they contain about I per cent. of nitrogen, or they may be dug in the ground as a fertiliser. The extraction of oil does not require expensive machinery, and the residue, which contains 7.5 per cent. of nitrogen, furnishes a valuable cattle food or manure. African unshelled and shelled ground-nuts yield 32 and 50 per cent. of oil respectively. Oil 
extracted locally in East Africa has been valued as high as $£ 40$ per ton. Two pressings are usually made. The first, or cold pressing, which produces the finest quality, furnishes about 20 per cent. of oil, the remainder being extracted with the aid of heat. The seeds are sown 2 to 3 feet apart and the crop is produced five or six months after sowing.

Chillies are usually raised from seed in prepared nursery beds. The young plants may be transplanted when they have grown 2 or 3 inches high, and planted in rows 3 feet apart and about 2 feet apart in the rows. Chillies should be harvested with the stalks attached, and carefully dried in the sun. These stalks should, however, be picked off before shipment. I,500 lbs. per acre is considered a fair crop, but as much as $2,500 \mathrm{lbs}$. per acre has been obtained. The market price of Zanzibar chillies has fluctuated during the last two years between I7s. and $25 \mathrm{~s}$. per civt.

The exports of maize from Tropical and Sub-tropical Africa have increased considerably during the last few years. The yield in East Africa varies between four and ten bags of $203 \mathrm{lbs}$. weight per acre, but in the corn belt of the United States the yield is as high as twenty-two to twenty-four bags per acre. Natal maize realised about $£ 7$ per ton in the London market in 1907. The large growing varieties should be planted 3 by 3 feet apart, but for the smaller growing varieties 3 by 2 feet is sufficient.

Cassava has been profitably cultivated as a catch-crop with Hevea in some of the plantations in the East. It would, however, seem preferable, for reasons already described, to choose some other crop less closely allied to Hevea. Cassava belongs to the genus Manihot, which like Hevea is a member of the Euphorbiaceous family.

No matter what plants are grown as, secondary crops with rubber they should on no account be allowed to interfere with its development. This frequently occurs owing to the secondary crops being planted too close to the rubber. The rate of radial root-growth of Hevea varies considerably under different conditions, but it will generally be greater in light open soils than in those of a closer and richer consistency. It is considered that when the tree is growing satisfactory a space of at least $I$ to $I_{2} \frac{1}{2}$ foot per year radial increase of root-growth should be allowed for. 
The undermentioned table shows the number of plants required per acre when planted at various distances apart and the amount of land available for each plant :-

\begin{tabular}{|c|c|c|c|c|c|}
\hline $\begin{array}{l}\text { Distance } \\
\text { Apart. }\end{array}$ & $\begin{array}{l}\text { Space avail- } \\
\text { able for } \\
\text { each Plant. }\end{array}$ & $\begin{array}{l}\text { No. of } \\
\text { Plants. }\end{array}$ & $\begin{array}{l}\text { Distance } \\
\text { Apart. }\end{array}$ & $\begin{array}{l}\text { Space avail- } \\
\text { able for } \\
\text { each Plant. }\end{array}$ & $\begin{array}{l}\text { No. of } \\
\text { Plants. }\end{array}$ \\
\hline Feet. & $\begin{array}{c}\text { Square Feet. } \\
\text { I }\end{array}$ & $\begin{array}{c}\text { Per Acre. } \\
43,560\end{array}$ & $\begin{array}{l}\text { Feet. } \\
\text { IO } \times \text { IO }\end{array}$ & $\begin{array}{c}\text { Square Feet. } \\
\text { I } 00\end{array}$ & $\begin{array}{c}\text { Per Acre. } \\
435\end{array}$ \\
\hline $\begin{array}{l}I \times I \\
2 \times I\end{array}$ & $\begin{array}{l}1 \\
2\end{array}$ & 21,780 & $12 \times 12$ & I 44 & $\begin{array}{l}435 \\
302\end{array}$ \\
\hline $2 \times 2$ & 4 & 10, I 90 & I $5 \times 15$ & 225 & I93 \\
\hline $2 \times 3$ & 6 & 7,260 & $16 \times 16$ & 256 & 170 \\
\hline $3 \times 3$ & 9 & 4,840 & $17 \times 17$ & 289 & I $5 \mathbf{I}$ \\
\hline $4 \times 4$ & 16 & 2,722 & $\mathbf{1} 8 \times \mathbf{I} 8$ & 324 & I 34 \\
\hline $5 \times 5$ & 25 & $1,74^{2}$ & $20 \times 20$ & 400 & 109 \\
\hline $6 \times 6$ & 36 & 1,2 IO & $25 \times 25$ & 625 & 69 \\
\hline $7 \times 7$ & 49 & 889 & $30 \times 30$ & 900 & 46 \\
\hline $8 \times 8$ & 64 & 681 & $40 \times 40$ & 1,600 & 27 \\
\hline $9 \times 9$ & $8 I$ & $53^{8}$ & $45 \times 45$ & 2,025 & 21 \\
\hline
\end{tabular}

\section{WEEDING AND HARROWING.}

Even when no secondary crops are grown with rubber, weeds must be constantly checked. On level lands they should be regularly hoed up; if this be done on steep sloping lands heavy rains will wash away the fine surface soil, so cutlassing should be resorted to. When trees are planted fairly closely together, or between-crops grown, weeding will require most attention during the first three or four years following the establishment of the plantation; after this period the shade produced by the trees has a beneficial effect in keeping weeds down. It is reported that the following "weed-killer" has proved successful in exterminating "Illuk" grass in Selangor: 2 lbs. $14 \mathrm{oz}$. of washing soda was dissolved in 3 gallons of water; this was raised to the boiling point and 2 lbs. of white arsenic slowly stirred in and then diluted with 20 gallons of water to form the stock solution. Two pints of stock solution mixed with 5 gallons of water were sprayed on the grass or applied by allowing a cloth suspended from a tank, containing the solution, on wheels to be drawn over the grass:

Comparatively few planters sufficiently appreciate the benefits 
accruing from frequently harrowing or cultivating the land between the trees. This operation not only checks the growth of weeds but breaks up the surface crust which forms after rain, thereby facilitating the ingress of air. During the dry season the layer of dry, loose soil thus formed serves as a blanket to conserve the moisture in the soil beneath. It is inadvisable to stir the soil too deeply during the dry season, as evaporation is greater from the cultivated than from the uncultivated soil, and a shallow layer of dry soil is almost as effective as a deep one for moisture conservation purposes. It may appear contradictory, but the same conditions which most favour the retention and conservation of rain water also best facilitate the draining away of surplus water. A loose soil absorbs more water than a compact soil, and surplus water drains away far more rapidly from soils in the first than from those in the second condition. However satisfactory the climatic conditions or the composition of the soil may be, unless the physical condition of the soil be suitable the best results will not be obtained.

Due care must, of course, be exercised in regulating the length of the teeth of the harrow or cultivator to prevent injury to the roots of the trees. Where, as frequently happens, the roots have formed a network near the surface of the ground close to the trunks of the trees, operations should be suspended in these areas and mulching applied in the shape of weeds, leaves, or, preferably, stable litter.

Drainage is necessary to improve the sanitary condition of the soil and promote the formation of soluble plant-food constituents.

Drains on hill slopes check the washing away of rich surface soil, and in such situations small drains at fairly frequent intervals are preferable to large drains widely distributed.

\section{Disbudding and Pruning.}

There is a vast difference in the habit of Hevea trees; some will commence to branch when they have grown 6 feet high, while others will grow more than 20 feet high before branching. Later on it will be shown that it is considered desirable to encourage the girth development of the 7 or 8 feet of the trunk 
nearest the ground; this being the most accessible region for tapping operations.

Horticulturists who wish to alter the natural habit of tall growing or straggly plants into a compact or standard habit either disbud or prune them when young. Tea and coffee planters adopt similar methods to encourage their crops to assume a low-branched habit to facilitate the harvesting of the "leaf" and "berry" respectively.

The inclination of Hevea trees to form long unbranched stems may also be checked by disbudding and pruning the young trees. The former operation is preferred as less loss in growth is associated with it. Trees which have grown 7 or 8 feet high without exhibiting signs of branching should have their terminal buds removed; this may either be effected with the thumb-nail or a sharp knife. New shoots are then produced in the axils of some of the leaves nearest the apex of the plant. These shoots may be similarly treated until the desired number of branches has been obtained. Some trees obstinately refuse to produce more than one new shoot when the first bud is removed, but if the process be repeated the wished-for result will be secured. As it is undesirable to allow branches to develop from the area which it is proposed to tap, buds which appear thereon should also be removed. Young trees, which have been allowed to grow beyond the height at which branching is desired, may be pruned back to this height. It is, however, advisable to take this work in hand as early as possible, both to prevent the loss of growth and as it will be usually found that new buds are more readily encouraged to form on the young wood.

Sturdy, compact growing trees are far less liable to be broken by wind than long whippy specimens. In the chapter on tapping it will be shown that under ordinary conditions tapping operations may commence when trees have acquired a girth of 20 inches at 3 feet from the ground. It will thus be apparent that trees whose girth has been increased by disbudding or pruning will come into bearing at an earlier age than those left to grow naturally. 
Chemical, Physical, and Biological Conditions OF SoILS.

THE investigation of various soils in which Para rubber trees have been successfully cultivated tends to show that it is not fastidious in regard to its requirements in this respect, as the chemical and physical qualities of many of these soils are comparatively poor. Below is given an analysis of soil from the Heneratgoda Garden, Ceylon, in which Hevea trees have been grown for about thirty years, and also an analysis of soil taken from the uncultivated pasture land adjacent.*

Chemical Composition.

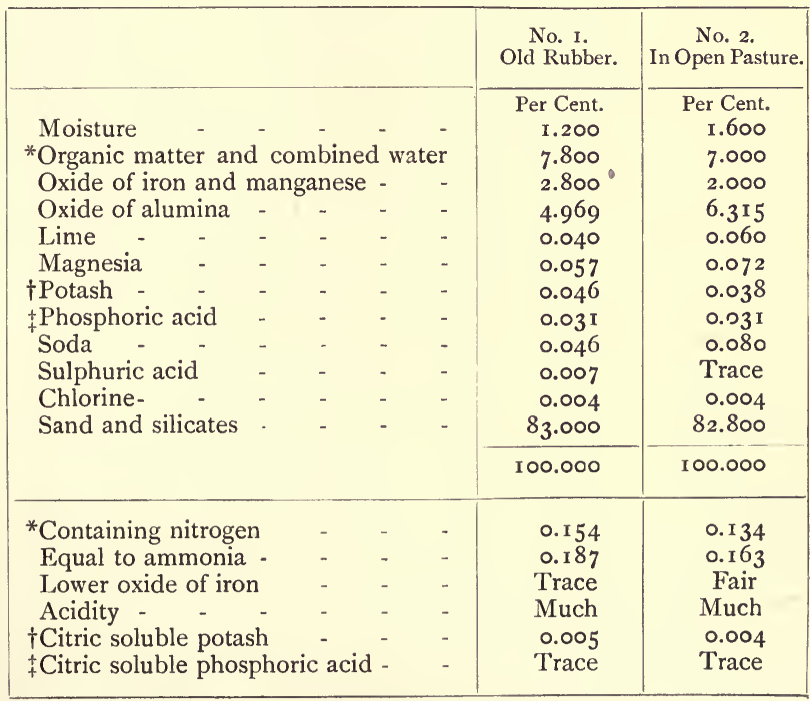

* Circular, Royal Botanic Gardens, Ceylon, vol. iii., No. 6. 
Mechanical Composition.

\begin{tabular}{|c|c|c|c|}
\hline . & & $\begin{array}{l}\text { No. I. } \\
\text { Old Rubber. }\end{array}$ & $\begin{array}{c}\text { No. } 2 . \\
\text { In Open Pasture. }\end{array}$ \\
\hline $\begin{array}{l}\text { Fine soil passing } 90 \text { mesh } \\
\text { Fine soil passing } 60 \text { mesh } \\
\text { Medium soil passing } 30 \text { mesh - } \\
\text { Coarse sand and small stones - }\end{array}$ & $\begin{array}{ll}- & - \\
- & - \\
- & - \\
- & -\end{array}$ & $\begin{array}{c}\text { Per Cent. } \\
20.00 \\
28.00 \\
14.00 \\
38.00\end{array}$ & $\begin{array}{c}\text { Per Cent. } \\
26.00 \\
28.00 \\
21.00 \\
25.00\end{array}$ \\
\hline & & 100.00 & 100.00 \\
\hline
\end{tabular}

The Heneratgoda soils are light brown sandy loams in a good mechanical condition, though the retentive power of moisture is rather poor. The organic matter, although about normal for the district, must also be considered poor. There is a fair supply of nitrogen. The mineral plant food is generally poor, there being only a small quantity of available potash and only a trace of available phosphoric acid. The soils are both very sour.

It is of very little practical value to the rubber planter to tell him what mineral plant-food constituents are present in his soil ; what it is necessary for him to know is the amount of plant foods that is available in a soluble state. These foods must be in such a condition as to be soluble in the sap of the root cells; this is only approximately equivalent to the amount of mineral constituents which a I per cent. solution of citric acid is capable of rendering soluble and not that rendered soluble by strong mineral acids.

The study of what may be termed the biological condition of soil is of primary importance in modern scientific agriculture, and it is one with which the up-to-date planter must sooner or later be called upon to grapple. The amount of available plant food in the soil is very largely influenced by the number of nitrifying bacteria present. The nitrogenous compounds of organic matter which are present in most soils are, under favourable conditions, acted upon by bacteria which secrete a peptonising ferment and change them into ammonia, and ultimately to nitrates, in which condition they form a soluble plant food. The essential requirements for the life and multiplication of soil bacteria are air, moisture, and heat. Sour, water-logged land 
is always imperfectly aerated, indeed this is the only condition which excludes air from the soil. Rain water is an important factor in soil aeration, for as it sinks into the ground it displaces an equal volume of air, and as the water drains away air is drawn in after it. In undrained land air is displaced very slowly, and consequently the beneficial effects of rain water are lost. Although it has not yet been decided whether roots like leaves, breathe, still the fact remains that air is as necessary to roots as it is to leaves. In employing drained swamps or water-logged land for a plantation, a simple method, and one which may be generally relied on for testing whether the soil is sour, is to take samples of moist soil from different portions of the suspected region. Mix them all together, add sufficient water to enable them to be stirred into a paste and insert a piece of blue litmus paper. If after an hour has elapsed the paper in contact with the soil turns red, the soil is probably sour. To neutralise the acidity, broad-cast water-slaked lime at the rate of about 2,000 lbs. per acre. Stone-lime may be expeditiously slaked by covering it with moist soil until it is converted into powder, when it is ready for use. Applications of lime also materially assist the work of nitrification bacteria.

The temperature of water-logged soils is always lower than that of more porous soils, hence the growth of the trees planted therein would be checked and the amount of available plant foods reduced owing to the retarded operations of soil bacteria. After drainage, such land should be deeply cultivated and the soil left in a rough condition to facilitate aeration before planting commences.

The moisture content and physical condition of very light porous soils may be increased and improved by ploughing in animal or green manures.

De Candolle's theory that a crop continuously cultivated on the same soil is able to render it noxious to that particular crop by its excretions has recently been confirmed by Schreiner and Reed. It is claimed that the diminished yields of a crop cultivated continuously on the same land is not altogether due to loss of soil fertility but largely to these toxic excretions. It has, however, been proved that when the organic excretions of plants are acted upon by air or micro-organisms the condition of the soil is improved. It will be apparent that their poisonous 
excretions may be prevented from accumulating to any injurious extent both by cultivating rotations of crops and by proper tillage. The importance of the latter remedy cannot be too highly estimated in the cultivation of a permanent crop like Para rubber, which, when closely planted, debars the growth of intercrops.

\section{MANURING.}

On comparing the analyses of the soil in which Hevea has been growing for thirty years with that which has been under pasture at Heneratgoda, we find that the former has increased its supply of organic matter, nitrogen, and potash, but its lime and magnesia content has decreased. This is not altogether surprising, as it is generally found that lands occupied by trees are yearly enriched by the annual leaf fall. In addition to returning to the soil a large proportion of the elements used up in the development of the leaf, part of that obtained by the elaboration of the atmospheric carbon dioxide during the processes of assimilation which take place in the leaf is annually deposited. This annual mulching of leaves contains a considerable amount of organic matter which is converted into soluble plant foods by the atmosphere and nitrifying bacteria.

The soil has been also considerably improved by the various other beneficial agents which operate on lands occupied with thickly planted trees. The network of roots formed by them holds the particles of soil together and checks the rain washing away soluble plant foods. Soil moisture is conserved through being shaded from the sun by the foliage of the trees, and the conditions favouring the development of nitrifying bacteria are ameliorated.

On rubber estates where these natural soil improving agencies are allowed to proceed unhindered, the principal losses that the soil sustains are the elements consumed in the building up of the stems and branches of the rubber trees and those contained in the bark excised and the latex extracted during tapping operations.

It will thus be apparent that, providing good land has been selected for the plantation, and there is no excuse for choosing poor land, considering the enormous areas of rich virgin land in the tropics well adapted for rubber cultivation now lying idle, 
manuring should not be necessary for many years providing proper attention be given to soil cultivation. Where such lands are chosen, a judicious rotation of catch-crops may be grown which will not severely impoverish the soil, especially if the plants be buried after harvest with dressings of basic slag or lime. The planting of green crops for manurial purposes alone under these conditions would be unnecessary waste of capital during the early life of the plantation; later the trees should have grown sufficiently to shade the ground and thus prevent their being cultivated. Where poor land, deficient in organic matter, has been selected for rubber cultivation, green manures, and especially those belonging to the legume family, which are able to fix atmospheric nitrogen by the aid of the bacteria associated with the nodules on their roots, may be beneficially cultivated.

These crops also improve the mechanical condition of the soil by the action of their roots, and when they decompose, acids are formed which assist in rendering additional plant foods available in a soluble form. The following are among some of the most valuable kinds for rubber plantations:-Vigna spp., "Cow Pea "; Cajanus indicus, Spreng., "Pigeon Pea" ; Crotalaria spp. ; and Arachis hypogaea; Linn., "Ground-nut." All these can be readily grown from seed, of which from 20 to 30 lbs. per acre is required. Various species of leguminous trees, such as Albizzia moluccana, Erythrina spp. and Pithecolobium spp., can also be employed with advantage, and if regularly pruned furnish a valuable mulch, or better still ploughed into the ground with a dressing of lime or basic slag. Mimosa pudica, the "Sensitive Plant," has been recommended as a permanent green cover to keep down weeds. It has been estimated that 150 to $200 \mathrm{lbs}$. of nitrogen per acre could be annually added to the soil by cultivating this plant, cutting it down, and turning it under the soil.

The compact growing varieties of "Cow Peas" are specially recommended. They grow rapidly on the poorest soils even during the dry season, and their foliage contains a high percentage of valuable manurial matters, i.e., .27 per cent. nitrogen, . Io per cent. phosphoric acid, and .3 I per cent. potassium oxide. It should be distinctly understood that various other plants, such as maize and sorghum, which are occasionally used as green manures, only increase the organic matter in the soil, whereas leguminous crops furnish in addition to this, supplies of 
nitrogen, which they directly absorb from the atmosphere. It is well to point out, however, that all soils do not contain the necessary nitrogen-fixing bacteria, or they may be unable to produce the desired results through having lost their activity. Active bacteria may be introduced to soils by inoculating the leguminous seeds to be planted with specially prepared cultures of the organism. The whole process is fully described in Farmers' Bulletin, No. 240, "Inoculation of Legumes," issued by the United States Department of Agriculture.

Although common salt was used as a crop fertiliser by the Romans and the Chinese before the Christian era, it is comparatively little used for this purpose at the present day. It is a powerful factor in breaking up soil and in rendering plant-food constituents free, Applications of salt during periods of drought are especially advantageous, as it absorbs moisture from the atmosphere and aids the retention of moisture in the soil. It is not generally known that salt is one of the principal ingredients of various artificial manures. The amount to apply must, of necessity, depend upon circumstances, but 600 lbs. per acre broad-cảsted may be considered an average application; less is, however, required on heavy soils, while a larger quantity would probably prove more beneficial to light soils.

Excessive applications of nitrogenous manures are not advisable for Heveas, as they tend to produce too rapid growth and render the trees more susceptible to being broken by wind. Different soils will obviously require fertilisers containing different percentages of the various manurial elements.

The following mixture has been found to yield good results, but the proportion of the constituents may be regulated to suit particular requirements :-

\begin{tabular}{|c|c|c|c|c|c|}
\hline Basic slag - & - & - & - & - & $\mathrm{I}, 500 \mathrm{lbs}$ \\
\hline Nitrate of soda & - & - & - & & 250 \\
\hline Sulphate of potash & - & - & . & - & 250 \\
\hline
\end{tabular}

This should be applied at the rate of about $300 \mathrm{lbs}$. per acre, and ploughed or harrowed in.

Cattle manure is specially valuable for soil which is poor in organic matter; this should be applied at the rate of 8 tons per acre, and, if circumstances permit, ploughed in. These soils would also be materially improved by applications of vegetable matter, such as leaves, grass, wyeeds, \&c. 


\title{
CHAPTER VII.
}

\author{
PESTS.
}

Conditions which Favour the Spread of Disease.

Nothing is more favourable to the spread of disease than the practice which now obtains of planting large areas with a single product.

Where large areas of a permanent crop such as rubber are cultivated, the difficulties attending the prevention and extermination of disease are far greater than in the case of an annual crop, for with the latter a change of crop will invariably produce these results. It therefore behoves the Para rubber planter to be constantly on the alert with a view to discover disease in its early stages, and take immediate steps to eradicate it. Investigate the xtiology of a disease, remove the cause, and the illeffects will be removed with it. Fortunately, none of the numerous fungus and insect pests of Hevea have, as yet, caused serious damage, but it should be borne in mind that, with a comparatively few exceptions, the cultivation of this product is of quite recent date. The advantages likely to accrue from the cultivation of between-crops with Para rubber have already been pointed out. In place of, or preferably in addition to these, belts of unrelated trees or plants should be grown for the purpose of dividing up large areas of Hevea with a view to still further check the spread of disease.

Since it generally happens that a specific disease confines its attacks to nearly allied species, the plants chosen for the betweencrops and the disease-checking belts should be selected from those belonging to different natural orders of plants from that to which Hevea belongs, viz., Euphorbiaceæ. For economic reasons the plants chosen should yield commercial commodities. Those suitable for between-crops have already been dealt with. For the second purpose there are several rubber-producing trees which are admirably adapted, such as Castilloa elastica, Cerv., 
the source of Central American rubber; Ficus elastica, Roxb., the Rambong; and Ficus Vogelii, Miq., and Funtumia elastica, Stapf, both West African trees. Where forest land is being cleared and land is plentiful and cheap, belts of indigenous trees might be advantageously left standing.

In some districts animals cause considerable damage by eating young Heveas and the bark of old ones; the most troublesome being cattle, pigs, porcupines, deer, rats, hares, and rabbits. As a protection from these a wire netting boundary fence of a suitable mesh should be erected.

\section{Fungus Diseases.}

The enormous losses which farmers and planters in various parts of the world have sustained by the ravages of parasitic fungi on growing crops should be sufficient to convince the Para rubber planter of the necessity of employing every means in his power to protect his trees from similar attacks. Striking examples of this nature are afforded by- "Potato Disease" (Phytophthora infestans, De Bary), "Vine Mildew" (Plasmopara viticola, De Bary), "Wheat Rust" (Puccinia graminis, Pers.), "Cocoa Canker" (Nectria sp.), and "Coffee-leaf Disease" (Hemileia vastatrix, Berk.). In Prussia, during the year I89I, it is estimated that losses amounting to over $20 \frac{1}{2}$ million pounds sterling were sustained by the ravages of parasitic fungi on cereal crops. Rust in Australian wheat is estimated to have caused a loss of $2 \frac{1}{2}$ million pounds sterling during the season I890-I, while the coffee-leaf disease in Ceylon is reported to have resulted in a loss of nearly I 5 million pounds sterling in ten years.

Every planter should make himself conversant with the general habit and name of the commonest groups of the fungus parasites of plants, their methods of attack, and the conditions which most favour their development.

It is impossible to state what proportion of the fifty thousand odd species which represent the world's fungus-flora is parasitic on plants, but it is well to bear in mind that many saprophytic fungi, i.e., those which usually live on dead organic matter, may assume a parasitic habit, while on the other hand parasitic fungi may adopt saprophytic habits. 
The vegetative form of a fungus consists of mycelium or hyphæ, which performs similar functions in the way of obtaining and assimilating nutriment for the fungus plant as roots and leaves perform for flowering plants. With few exceptions, the mycelium of parasitic fungi remains within the tissues of the host plant, so that the casual observer only sees the fruiting or reproductive stage, by which time the fungus has completed its work of destruction. It will thus be seen that, notwithstanding the fact that the reproductive form of the fungus has been found on dead tissues, it does not follow that it is a saprophyte, as it may have killed them; nor does it follow that because a fungus has been discovered growing on dead tissues that it has killed them.

The commonest method of infection is by spores, which for all practical reproductive purposes may be considered to take the place which seeds occupy in regard to flowering plants. Spores are minute bodies of various colours and shapes, many thousands being required to cover a threepenny bit. These are produced in enormous quantities, and are readily distributed by wind, rain, insects, animals, man, and numerous other agencies. Any which alight on a suitable host germinate and spread the disease.

The difficulties attending the attempts to exterminate fungus diseases have been frequently demonstrated, and as examples may be quoted those employed in regard to "rust in wheat," vine mildew, and coffee-leaf disease. Too great stress cannot be laid on the necessity for adopting preventive methods by promoting sanitary conditions on the plantation, proper cultivation, selecting seeds from healthy plants, and burning diseased tissues.

Always have a stock of fungicides and apparatus, such as sprays, to apply them, at hand to treat a disease in its early stages, for it is then often possible to check and even exterminate it, whereas this may be impossible later. The most favourable conditions for the development of parasitic fungi are "heat" and "moisture." Sunlight is an important factor in checking them, so that closely planted estates offer more favourable conditions for the spread of disease than where trees are planted wider apart. 


\section{FUNGICIDES.}

Fungicides are plant poisons diluted to such an extent that they are harmless against the thick-walled tissues of the host plants but sufficiently strong to destroy the tender fungus tissues.

The following fungicides have been selected from those which have given the best results in the treatment of fungus pests :-

Bordeaux Mixture.-This is usually prepared by dissolving copper sulphate in water and mixing this with lime water. The following proportions and mode of preparation have given generally satisfactory results: Weigh 2 lbs. of copper sulphate, and immerse this, tied up in a piece of sacking, in 8 gallons of water. Slake $I_{2}^{\frac{1}{2}} \mathrm{lb}$. of lime, add water in small quantities and stir until a perfectly smooth paste is obtained, then add sufficient water to make 8 gallons of lime water. This should be thoroughly stirred and when cool slowly mixed with the water in which the copper sulphate has been dissolved. Professor Pickering has recently suggested the following proportions as being more economical and quite as effective, viz., 2 lbs. of copper sulphate and 27 gallons of clear, saturated lime water. We have not experimented with this mixture, and should advise tests being made before applying it on a large scale.

Potassium Sulphide Solution.-Mix potassium sulphide, or what is better known as "liver of sulphur," in the proportion of $\frac{1}{4} \mathrm{lb}$. to a gallon of hot water, then add sufficient water to make 9 gallons of the solution.

Ammonia and Copper Carbonate Mixture.-Mix $\frac{1}{4} \mathrm{lb}$. of carbonate of copper with $1 \frac{1}{4} \mathrm{lb}$. of carbonate of ammonia, and thoroughly dissolve in hot water; then add sufficient water to make 64 gallons of solution.

Each of these mixtures may be applied with sprays fitted with nozzles which distribute the liquid in the form of a fine mist.

Hevea Canker.-The fungus which is responsible for the disease known as "Hevea Canker" belongs to the genus Nectria and is therefore nearly allied to that which produces "Cocoa Canker." Carruthers, in his report upon his investigations of the first mentioned disease, states * that he found it on almost

* Circulars of the Royal Botanic Gardens, Ceylon, vol. ii., No. 29, 1905. 
all parts of the tree except the young branches and the roots. He considers that "the external colour of the bark in places where the canker is present is in many cases different from that of healthy parts, but no actual colour can be given as typical of a canker spot. As a rule it is darker in colour and the surface of the bark somewhat different." .. . "The tissue under the outer bark, however, always shows by its colour when there is any considerable quantity of the canker fungus mycelium present. Instead of a bright clear yellow, as is found in the healthy bark of the Para rubber tree when cut, the colour of the cankered tissue recently attacked is of a dirtier yellow or even a neutral tint, and when the fungus has got complete hold the tissue is claret-coloured and not unlike the inside of the fruit wall of a ripe mangosteen. An important fact to be observed is that in those areas invaded by the mycelium of canker fungus no latex will be found at all."

As with many other fungi Nectria has two reproductive forms, and Carruthers states, with regard to the species under review : "The spores are of two kinds; the first spores produced, which are called 'Conidiospores,' are of a whitish-grey colour in mass, and look somewhat like thick white mould. Later on, and produced at the same places, pushing their way out from behind the conidiospores, are the perfect fruits of the fungus or perithecia, which are characteristic of the groups Nectria, to which the fungus belongs. They are, when seen with the naked eye, like grains of red pepper, sometimes a mass of them occupying a space as big as a ro cent piece, or even bigger. When looked at through a lens they will be seen in shape not unlike minute strawberries, some ten to fifteen making a mass about equal in size to a pin's head; they are roundish with a point when fully formed." The method suggested for combating this disease is the excising away of diseased tissues with a sharp knife and burning them on the spot. As a preventative measure trees in infected districts might be sprayed with Bordeaux mixture, which would render the parts sprayed immune from infection so long as the copper sulphate is present. It would be advisable to keep trees from which diseased parts have been excised under constant observation for a few months, for if any mycelium has been left behind the disease would probably reappear. 
In 1903 the Ceylon Government Para rubber plantation was badly infected with canker; the following year it was placed in the hands of the Mycologist for treatment, some 6,000 trees fourteen years old being destroyed. In 1906 it was reported that the whole plantation was in good condition, so it would therefore appear that when proper steps are taken this disease may be checked.

"Die Back."-This disease principally affects trees about one year old. It usually commences near the top of the plant, and, unless the diseased portion be cut off, travels down the stem and completely kills the whole plant. Petch has discovered a fungus on diseased areas which he has described as Gleosporium alborubrum, Petch, but he states that his infection experiments with this fungus have been unsuccessful. To check the spread of this disease, it would be advisable to cut off all infected parts of the tree and burn them. He also found a species of the same genus, $G$. brunneum, on young Hevea seedling leaves which had turned yellow and dropped off.

This genus is of considerable importance from a pathological point of view, as its members are responsible for the following well-known diseases: "Grape Rot," "Banana Anthracnose," “Apple Rot," “ Plane-leaf Scorch,” and "Raspberry Spot.”

Hevea Stump Disease.-Hevea stumps, both in Burma and Ceylon, have been attacked, according to the same observer, by Botryodiplodia elastica, Petch. In each case the plant had been attacked by this fungus at the collar. He suggests, as it probably enters the stem through injuries made during planting, that plants should be raised in baskets or seed sown to stake.

Decay in Tapped Areas.-Petch has observed three instances where the mycelium of Pleurotus angustatus, B. and Br., had travelled from the decayed portion in the trunk caused by tapping, to the sound wood.

Wound Parasite (Corticium javanicum, Zimm.). - This fungus is reported to attack a large number of different trees, Hevea included, in Java, Straits Settlements, India, and Ceylon. Its presence may be observed by a lilac-pink coating on the stem. The bark and cortical tissues are destroyed, and cankerous wounds are often caused by it. Combative methods similar to those suggested in regard to Hevea canker would probably 
give beneficial results. A closely allied species, C. comedens, Fries, is parasitic on young oak branches.

Root Diseases.-Fomes semitostus, Berk., has been found attacking Hevea roots both in Ceylon and the Straits Settlements. Petch states:* "Fomes semitostus always develops first on jungle stumps, and spreads from them to the Hevea by means of white threads in the soil. There is no case in Ceylon of a direct attack on Hevea, and the fructification has never been found on Hevea in Ceylon, except in the case of those cultivated for the purpose at Peradeniya. The spores of the fungus are blown on to the jungle stump and develop there until the stump is partly consumed. The mycelium then spreads to the neighbouring trees, and at the same time advertises its presence by producing its fructification on the stump. I have never found any difficulty in deciding which stump the fungus originated on. The method of prevention is obvious, though it may be expensive. Jungle stumps must be removed."

"The fruiting portion of Fomes semitostus is a broad, flat, rounded plate often very irregular in form, usually reniform, 4 to 6 inches across, and of an orange-red colour beneath, paler above, where it is marked with rings and fine striæ; beneath can be seen with a lens the honeycomb-like structure of the hymeneal surface. The texture of the fungus is tough, and it possesses a strong mushroom-like scent." †

Several species of fungi belonging to this genus cause various tree diseases, the best known being "Root-rot of Conifers," "Tinder Fungus," and "Gooseberry Polyporus." In addition to destroying all tree stumps in the neighbourhood, and infected Heveas, the ground in which the latter were growing should be isolated by encircling it with a narrow trench to prevent the mycelium spreading.

In the Straits Settlements, a fungus (Helicobasidium sp.) has been found attacking the roots of the tree. A species of the same genus is reported by Massee to be very destructive to mulberry trees in Japan. This fungus rapidly spreads from tree to tree by the agency of strands of mycelium in the soil. Should

* "Lectures and Discussions on Rubber Cultivation and Preparation, Ferguson, 1906.

+ Ag. Bull. of the St. Settlements and F.M. States, May Igo4. 
this disease appear on a plantation, its spread may be checked by digging a trench about a foot deep around each affected tree, throwing all soil taken from the trench within the circle and dusting it with powdered sulphur.

Trees destroyed by the fungus ought not to be allowed to lie rotting on the ground, but should be burned, as they form hotbeds for the propagation and dissemination of the disease.

In the Malay States also a fungoid root parasite has been found attacking the roots of some trees.

Mr Stanley Arden says: * "There has been some discussion as to whether the loss of trees is attributable to this fungus or to the ravages of the white ants, or to both, but in the large majority of trees I have examined, neither one nor the other could be said to have killed the tree. Had the trees been killed by the fungus there would doubtless have been some indication of its presence some time previous to the tree falling over; but, as already stated, at the time of falling the trees generally appeared to be in a robust condition, and I incline to the belief that the fungus had prepared the way for the ants, which by eating away the heart of the trunk had caused the trees to fall simply for want of support."

Leaf Diseases.-According to Petch, "the commonest leaf fungus of Hevea is that of 'Grey Blight,' Pestalozzia guepini, Desm.; this is comparatively harmless on leaves but kills the seedling when it attacks the stem at the collar; the diseased patch usually takes the form of a white ring surrounding the stem, bordered by a purple-brown line."

It is important to remember that this is one of the most destructive parasitic fungi which attack the tea plant both in India and Ceylon. Massee states: "As the mycelium is not perennial in the tea plant, if all affected leaves were collected with the amount of care and intelligence exercised in collecting sound leaves, and burned at once after being collected, the disease would soon be stamped out."

Another fungus which attacks Hevea leaves is Helminthosporium hevea, but though abundant is of less importance than the previously mentioned species. This causes small round transparent spots on the leaves; these spots are usually

* Report on Hevea brasiliensis in the Malay Peninsula. 
surrounded by a brownish protuberance from which the reproductive form of the fungus is produced.

With a view to extermination all infected leaves should be collected and burnt.

\section{INSEĆT PESTS.}

Healthy Hevea trees are to a very large extent self-protected from insect attacks by the viscid latex which exudes when the bark or epidermis is injured. In the majority of instances where bark-eating beetles have proved injurious to Heveas it has been observed that the tree's vitality had been first lessened through some other cause. Green placed a number of Longicorn barkeating beetles in a large cage, together with a healthy young Hevea plant. They bit the bark of the plant, causing the latex to flow over their mouths, which they did not appreciate. They relinquished the attack and endeavoured to clean away the viscous fluid. During seven days' confinement without food no further attempt was made to feed on the plant. But upon being placed in another cage with partially dried rubber plants and twigs of non-laticiferous trees they commenced to feed voraciously.

Although it has not been definitely decided whether latex does or does not play an important part in the nourishment of Hevea trees, there is not the slightest doubt that it is a valuable factor in protecting the plant from insect pests. It is therefore imperative, if advantage is to be taken of this natural protection, that the tree should be maintained in a healthy state and not denuded of latex through over-tapping. Wood exposed by careless tapping is devoid of latex and consequently more susceptible to insect attacks, as also are seedlings which, in process of transplanting, have been allowed to wilt either through being left out of the ground for a long time and their roots and leaves unduly exposed or are planted during protracted dry seasons without irrigating.

It is important to bear in mind that many insects pass through three stages. From eggs are hatched caterpillars or grubs. These eventually change to a pupal or resting stage, i.e., chrysalis, from which the "perfect insect" (butterfly, moth, or beetle, \&c.) emerges. It is generally in the larval or caterpillar 
stage that a particular insect is most destructive. It will, however, be readily recognised that where a butterfly, moth, or beetle is known to be the parent of a troublesome grub every possible means should be employed to destroy it. In the same way by studying the life-history of a destructive insect it is sometimes possible to check its ravages by destroying its eggs. Night-flying moths and beetles may be trapped by placing vessels containing thick sweetened matter such as molasses near lights. Many boring beetles may be trapped in this way.

Termites-“"White ants" (Termes gestroi, Wasm.).-Although termites have proved destructive to Hevea in the Malay Peninsula and in India, it is reported that they have never been known to attack this tree in Ceylon unless it had been previously debilitated by a fungus or some other factor.

The manager of the Government rubber plantation, Mergui, reports that he had three trees, I to 2 feet in girth, dug up, on which the termites had just begun operations. The roots and trunks appeared perfectly sound, but the bark at the base and on about $I_{2} \frac{1}{2}$ foot of the portion underground was perforated by the ants. In one tree attacked by white ants, having a circumference of 3 feet 6 inches, measured 3 feet from the ground, he collected $6 \mathrm{lbs}$. of rubber, apparently the result of the ants' attacks. The trunk of this tree was hollowed out to a height of 7 feet. The same observer states: "Termes gestroi seldom attack a Hevea under four years of age and I have never seen a tree under two years of age attacked."

White ants can be effectively exterminated by inserting carbon disulphide into their underground nests. This chemical is exceedingly volatile, and the fumes which it gives off are of a highly inflammable nature. Many shipping companies object to handle it, and consequently it is very expensive. An illustration of an apparatus which is reported to have given general satisfaction in the extermination of white ants in South Africa is given (Fig. 5). It is placed on the market by Messrs $P$. Henwood, Son, Soutter, \& Co., Durban, under the name of the "Universal Ant Destroyer." It consists of an air-pump connected by a length of rubber hose with a small furnace. Glowing charcoal is placed in the latter, and a spoonful or so of the mixture (stated by Green to consist of white arsenic 85 per cent. and sulphur 15 per cent.) supplied with the apparatus, 
is thrown on the charcoal. When the pump is at work a current of air is forced into the furnace. The air enters the lower part of the furnace and drives out the poisonous fumes produced by the combustion of the powder through a hole near the top of the furnace with which is connected a second flexible tube. In practice the nose of the latter is placed in a gallery of an ants' nest and the pump started. The fumes are driven into the galleries, and all crevices through which they escape should be

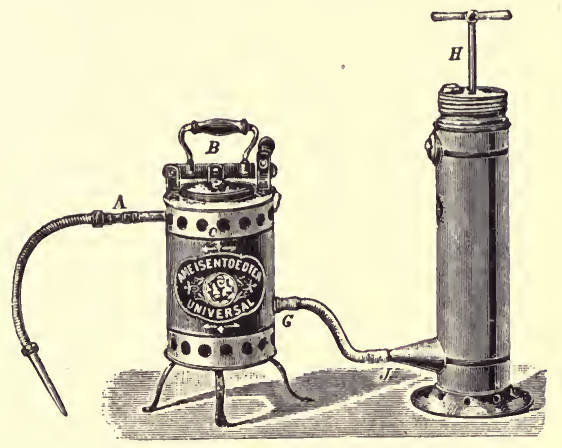

FIG. 5.- "The Universal Ant Destroyer."

stopped with clay. Two or three minutes' treatment is usually sufficient, but if, when examined a week later, any living termites be found the treatment should be repeated. The apparatus costs about $£_{4}$ in Natal. The Government entomologists of both Natal and Ceylon have tested it, and found it works satisfactorily.

\section{INSECTICIDES.}

In addition to fungicides, sprays, \&c., a stock of insecticides should be stored by every Para rubber planter.

Insect pests may be divided into three main sectionssucking insects, leaf-eating insects, and boring insects.

Sucking Insects are those such as plant-lice (aphidæ), scale insects, and mealy-bugs, \&c., which suck the plant juices by means of a slender tube which they insert into the tissues of the plant. To exterminate them it is necessary to apply what are known as "contact-poisons" which destroy the insects when 
they come in contact with their bodies. The following are amongst the most generally used "contact-poisons" :-

Kerosene Emulsion.-This is prepared by dissolving hard soap in the proportion of I lb. to every 2 gallons of boiling water. When thoroughly mixed, and while the water is still hot, 4 gallons of kerosene are slowly added for every pound of soap, and the mixture thoroughly churned with a force pump or syringe until it forms a cream. This is the stock solution, which previous to application should be diluted with 66 gallons of soft water.

Whale-oil Soap Solution is prepared by mixing whale-oil soap at the rate of $\frac{1}{2} \mathrm{lb}$. to every gallon of water (boiling).

Tobacco Solution is prepared as follows: Steep tobacco leaf at the rate of $\mathrm{I}$ lb. to every gallon of water for twenty-four hours, and afterwards strain through a cloth. Dissolve hard soap at the rate of $\mathrm{I} \mathrm{lb}$. to every Io gallons of water. Mix the tobacco water and the soap solution at the rate of I gallon of the former to Io gallons of the latter, and it is ready for use.

Leaf-eating Insects. - Although contact-poisons will often destroy many leaf-eating insects, better results are obtained by poisoning their food. This is done by spraying the leaves of affected plants with arsenical and other solutions, which are termed "Stomach poisons." Since the sucking insects obtain their nourishment from the interior tissues it will be obvious that it is impossible to poison them by this means.

The following "stomach poisons" will generally be found to give the desired results :-

Paris Green may be effectively applied either as powder or made up into a solution. By the first mentioned method it should be first mixed with twice its weight of starch, flour, or lime. Paris green solution is made by dissolving Paris green with lime at the rate of $\frac{1}{2} \mathrm{lb}$. of the former to $\mathrm{I} \mathrm{lb}$. of the latter to every IOO gallons of water.

London Purple may also be applied dry or in solution, and be prepared with lime, flour, or starch in a similar way and in like proportions to that suggested for Paris green.

Boring Insects.-Boring injuries to plants may either be caused by the "perfect insect," as in the case of some Longicorn beetles, or by their larvæ. Many beetles attack only dead stumps and debilitated trees. The remedy to apply in such cases has already been dealt with. 


\section{CHAPTER VIII.}

\section{LATEX.}

\section{FUNCTIONS OF LATEX.}

SEELIGMANN remarks: * "India-rubber is a hydrocarbide of a vegetable nature, extracted from the juice secreted by the protoplasm of a so-called primordial cellular tissue of a great number of trees, shrubs, and bindweeds of hot countries. The principal trunks of this tissue are situated in the internal zone of the bark, outside the liber of the bundles and their sclerose sheath when it exists. They send out numerous branches, some outwards, across the bark to the epidermis, where they terminate in a cul-de-sac; the others, less numerous, towards the interior cross the endodermis and the medullary rays, to the pith, around the periphery of which they diverge longitudinally. This carbide of hydrogen and its derivatives, the issue of the activity of the protoplasm, would not appear, at least according to certain naturalists, to be afterwards re-employed in the life of the plant, and is considered by them as a product of elimination, a reserve product, utilised by man in the arts and industries. Other men of science to whom we readily give in our adherence consider this carbide necessary, at least partially, to the life of the plant."

Scott decided, after investigating the laticiferous system of young Hevea seedlings from one to twenty-five days old, that the laticifers are definite vessels which have partition walls. The latter soon become absorbed, leaving continuous tubes. They are only found on the bast side of the cambium, from which they are formed in a continuous network. Latex is considered by some authorities to be excretory matter of no further use to the plant, so that if the whole of it could be extracted without damaging the plant's structure, no harmful results to its health 
would follow. Parkin writes : * "Personally I am not inclined to look upon latex as playing an important part in nutrition, and should imagine that if it were possible to extract all the latex from such a tree as Hevea brasiliensis without greatly injuring the other tissues, it would not be seriously harmed."

It is, however, only reasonable to suppose that latex is of some utility, if only a minor one, to the life of the plant, especially in view of the vast number of plants which contain it. As the greater majority of these are either tropical or xerophilous types, such as many Euphorbias, Asclepiads, and Dogbanes, it is possible that one of the main functions of latex is to protect the plant from too rapid transpiration. We are therefore led to wonder whether, if Hevea were cultivated in a hot dry region under irrigation, it would yield greater quantities of rubber than in districts where more atmospheric moisture is obtained. Latex is more abundant in Hevea trees when rains are plentiful, but it is not so rich in caoutchouc as during dry weather. Latex has certainly a beneficial effect in protecting the plant from certain bark-eating insects. Longicorn bark-eating beetles have been observed to attack the living bark of Heveas and immediately relinquish their efforts when the viscid latex commenced to flow, although no other food was available. Were trees drained of their latex they would obviously be more susceptible to the depredations of such pests.

Numerous instances are on record where the foliage-bearing portions of Hevea trees have been broken off by wind, or deliberately cut down so that nothing but the trunk remained, and, although no foliage has been produced for several years, they have yielded latex from which rubber of good physical properties has been manufactured.

\section{Chemical and Physical Properties of Latex.}

As far back as 1826 Faraday analysed the latex of Hevea which was sent to Europe from Brazil, and found the following :-

Gum elastic

Albuminous matter

Bitter nitrogenous colouring principles -

Substances soluble in water

Wax

Water slightly acid
Per Cent.

- 37.70

- $\quad 1.90$

- 7.13

- 2.90

- .13

- 56.37

* Circular, Royal Botanic Gardens, Ceylon, p. I I4, June I899. 
Seeligmann, loc. cit., gives the following results of an analysis made of fresh latex collected from a Hevea tree, twenty-five years of age, in Brazil during the year 1888 :-

Elastic matter

Nitrogenous organic matter (putrescible)

Mineral salts, sodic and calcic (no magnesic)

Resinous bodies

Water, slightly alkaline
Per Cent.

$$
\begin{array}{rr}
- & 32.00 \\
- & 2.30 \\
- & 9.70 \\
- & \text { traces } \\
55.0 \text { to } 56.00
\end{array}
$$

This latex was obtained from a gash made in the trunk of the tree about 20 inches from the ground. Its density was 0.9I9 at $57.2^{\circ}$ Fahr., and the caoutchouc globules measured on an average $3.5 \mathrm{I}$ micromillimetres.

Kelway Bamber found fresh latex obtained from cultivated mature Hevea trees when first tapped during more or less dry weather contained :-

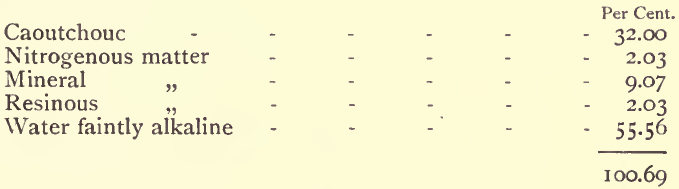

It would be interesting to know the cause of the comparatively large difference between the caoutchouc content of the latices examined by Faraday and Seeligmann. It is significant that after cultivated Hevea trees have been tapped several times the percentage of caoutchouc in the latex has been found to considerably decrease. In a series of tapping experiments conducted at the Singapore Botanic Gardens, a tree with a girth of I 2 inches gave from the first period of tapping (spiral method) $265 \frac{1}{2}$ oz. of latex, from which 9 lbs. of rubber were obtained; from the second period of tapping, one month later, the tree yielded $433 \mathrm{oz}$. of latex which only gave $4 \mathrm{lbs}$. I $5 \mathrm{oz}$. of rubber.

Kelway Bamber is reported to have stated at the Ceylon Rubber Exhibition (held in September 1906): "In all the latex sent to me recently and from what I hear from planters, the latex does not now equal that portion (i.e., 32.00 per cent. of caoutchouc), and the caoutchouc has in some instances gone down to I 5 per cent. or less"; and, "I think the amount of 
caoutchouc at present is practically permanent, but the amount of water in the latex has largely increased, as you see in the wound response."

Wright observed at the same Exhibition that some of the Heneratgoda trees when first tapped yielded latex which contained only 30 to 50 per cent. of water, whereas when the renewed bark was tapped the latex often contained as' much as 90 per cent. of water. Although, as pointed out above, the extra amount of latex produced is said to have kept the yield of caoutchouc constant, the subject merits serious attention.

The practical man will naturally be desirous of ascertaining to what extent this shrinkage in the caoutchouc content of the latex is likely to occur, and whether it is likely the trees will continue to yield a compensating amount of latex. Other questions which require solution in connection with this problem are, is this decrease of the percentage of caoutchouc due to too early tapping or over-tapping, and can it be remedied by manuring?

Rubber is present in latex in the form of minute globules two to three micromillimetres in diameter, similar to the butter fat in animal milk.

Resinous matter is also present, and this produces the brittle character common to many inferior rubbers.

Para latex obtained from the trunk of mature trees contains a very small proportion of resin, but it is more abundant in the latex of young trees and young branches.

The colour of the latex varies in different trees from pure white to pale yellow. This coloration is imparted by the rubber globules, as the solution in which they are suspended is practically colourless.

When fresh it is quite inodorous and almost tasteless, but acquires a foetid odour on exposure to the air, due to the action of bacteria on the putrescible nitrogenous matter present in the latex.

Latex on issuing from the tree has almost invariably a decidedly alkaline reaction but later assumes an acid character.

\section{StORING LATEX.}

Hevea latex when left exposed to the atmosphere rapidly decomposes owing to the action of bacteria, the proteids coagulate and carry down with them the caoutchouc globules. 
If it be desired this process can be retarded by adding ammonia or formalin. Although both these reagents produce the desired effect, their action on the latex is entirely different.

The ammonia does not prevent decomposition but neutralises the acids formed by the action of the bacteria, whereas formalin prevents decomposition by antisepticising the albuminous matter and thus preventing the growth of bacteria.

The amount of ammonia required can be ascertained by testing with litmus paper till a neutral solution is obtained. Weber suggested the addition of $\frac{1}{2}$ oz. to $\mathrm{I} \mathrm{oz}$. of formaldehyde (40 per cent. solution of formalin) to every gallon of latex to keep the proteids inactive. 
CHAPTER IX.

COLLECTING THE LATEX.

TAPPING.

"TAPPING" is the name given to the process employed for extracting the rubber-containing fluid, or latex, from rubberproducing trees and plants. It consists of cutting the bark in various ways sufficiently deep to penetrate to the latex-bearing vessels.

It is highly essential that this operation should be conducted in a manner that will give the maximum quantity of latex, and at the same time cause the minimum amount of damage to the health of the plants operated on. If the wood of the tree be damaged the upward flow of sap is checked, and consequently also the growth of the tree. No hard-and-fast rule can be laid down as to the exact age a tree should be before it can be safely tapped, as, generally speaking, the size, and not the age, of the tree indicates when it can be safely tapped. It has been proved beyond doubt that tapping may be conducted with perfect safety when a tree has produced a girth of from 20 inches to 2 feet at 3 feet from the ground. Where Para rubber trees have been grown under satisfactory conditions, they have attained this size in six or seven years from date of planting.

I have seen trees in Ceylon quite large enough to be tapped five years from the date that they were planted out.

Rubber is obtainable from young plants and seedlings, but it is inferior in quality to that produced by mature trees, as it usually contains a larger percentage of resin; and, moreover, methods have not been yet discovered by which it can be procured in sufficient quantity to make the collection of it a remunerative undertaking.

Although latex is produced by practically every portion of the fundamental tissue of the Para rubber tree, the greatest 
quantity is yielded by the lower portion of the trunk, and it is doubtful whether any great advantage is gained by tapping higher than about 8 or 9 feet from the ground; moreover, latex obtained from the young branches contains a greater percentage of resin than that from the trunk.

The methods employed in tapping rubber trees are extremely varied.

The rubber collectors in the Amazon valley use a small axe with a wedge-shaped blade about $I_{2}^{1}$ inch wide. With this they make an upward cut into the bark of the tree, and immediately fix beneath the cut a small cup, by means of clay, to collect the latex as it flows from the injured portion.

The native collectors in West Africa cut a long perpendicular channel in the bark of the tree, and then smaller transverse channels leading into it. The instrument generally employed is a grooved chisel. At the base of the perpendicular incision a receptacle is placed to catch the latex.

\section{TAPPING IMPLEMENTS.}

Numerous methods of tapping have been evolved since the establishment of the Para rubber industry in the East, but far more numerous are the implements placed on sale as being suitable for effecting these processes. A certain number of these implements are useful, but by far the greater number are not, and some of the latter class lead one to doubt whether the inventors have even seen a rubber tree. One of the first knives employed by rubber planters is shown in Fig. 6, i.e, the Eastern Produce and Estates Company's tapping knife. It is comparatively little used at the present day, as it has been superseded by implements better adapted to the new methods in vogue.

The handle of this instrument is made of wood and the remaining portion of steel. It is operated with both hands, one holding the handle and the other the neck of the instrument. Tapping is effected by making a downward cut, the wedgeshaped cutting portion of the instrument acting as a safeguard against penetrating too deeply into the trunk of the tree. By the agency of this instrument, and provided its cutting edge be maintained sharp, a thin wedge-shaped piece of bark can be cut out of the trunk with very little difficulty. 
One disadvantage in the use of this instrument is that pieces of bark get jammed in the apex of the triangular cutting portion and cause it to split. It is patented by the Eastern Produce and Estates Company, Ltd., 4I Eastcheap, London.

The following specification of the patent taken out for the

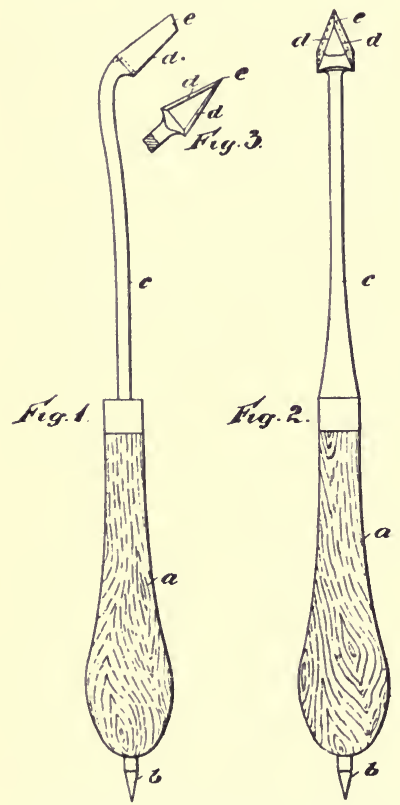

FIG. 6. - An Implement for Tapping Rubber Trees. instrument is given here as it appears in the India-rubber Journal of February 1904 :-

Patent No. 25,973 (1903). Date of application, 27th November I903. Accepted, I 7 th December 1903. The Eastern Produce and Estates Company, Ltd., 4I Eastcheap, London, merchants.

It is well known that indiarubber is the exudation of a tree, and is usually obtained by "tapping" or "bleeding" the tree by making slits, grooves, or cuts in the bark, generally in a slanting direction. As the gum exudes from the tree and flows down to the lower end of each incision, it is received into a small can or other vessel attached to the tree for that purpose.

It is most important that the "tapping" or "bleeding" operation should be carefully and properly performed, or the health and producing properties of the tree might be affected, or the tree might be killed. For example, the depth of the slits, grooves, or cuts should not be excessive, and the lower ends of two adjacent incisions should not meet or intersect, but should be stopped short before forming a complete $\mathrm{V}$ at the point of attachment of the collecting can or other vessel.

The implement forming the subject of this present invention enables the "tapping" or "bleeding" operation to be performed with facility and expedition without endangering the life or health of the tree.

In the accompanying drawing Fig. I illustrates the implement in side elevation, Fig. 2 is a view looking from right to left in Fig. I, and Fig. 3 is a projection of the underside of the cutting end of the implement.

$a$ is a wooden or other handle of suitable size and shape, preferably furnished at one end with a stabbing or piercing point $b$ for the purpose of 
making an initial incision in the bark of the tree before employing the cutting device which is mounted in the other end of the handle $a$, and consists of a haft or stem $c$ preferably of a curved shape as shown, its cutting end standing at an angle to the haft or stem $c$. The cutting device proper is of a hollow wedge or triangular shape as shown, the cutting edge being at $d$ and $e$.

It has been found that this implement may be placed in the hands of natives and unskilled labourers with much less danger of the trees being damaged or killed than when knives or cutters of other known shapes are employed.

It is obvious that the above-described implement is also applicable for "tapping" or "bleeding" other trees than those yielding india-rubber.

The Bowman-Northway tapping knives (Fig. 7) have found favour with a large number of planters in the East.

The following particulars taken from a catalogue published by Messrs Walker \& Co. of Colombo thoroughly explain their merits and the manner in which they should be manipulated:-

\section{How to use the Bowman-Northway Patent Rubber Tapping Knives.}

The No. I knife is specially designed to make the first groove when tapping old trees, which have a greater thickness of bark than young trees. It is used much like a plane, the head being suitably adjusted to shave the bark gradually. As soon as the proper depth is reached, the white coloured bark appears, and this becomes lighter and lighter the nearer you get to the cambium, so that by practice it is possible to tell when the right depth has been cut.

Young trees are more difficult to cut to the correct depth than old ones, as the white bark next to the cambium, mentioned above, is very thin indeed; it is therefore advisable, under these circumstances, to use the No. 2 knife from the start, and gradually reach the depth necessary by successive parings.

The No. 2 knife is used for paring the lower edge of the groove originally made with either No. I or No. 2, and when in use should be held so as not to make the cut deeper than the previous ones, which is effected by holding the knife at the proper angle. Leaning the knife over to the right makes the cut deeper, while leaning it over to the left reduces the depth, the object in every case being not to cut deep enough to touch the cambium. The No. 2 knife is provided with a guard or 
detachable steel blade which is designed to prevent cutting into the tree while regulating the thickness of the bark to be pared off, and this blade can be supplied in different widths as required, or can be filed down on the cutting sides of the knife so as to give wider cutting edges if required. These knives are usually supplied with a very narrow cutting edge so as to pare or shave off as thin a slice of the bark as possible, and therefore will not cut if scrap is left on. New coolies unaccustomed to using these

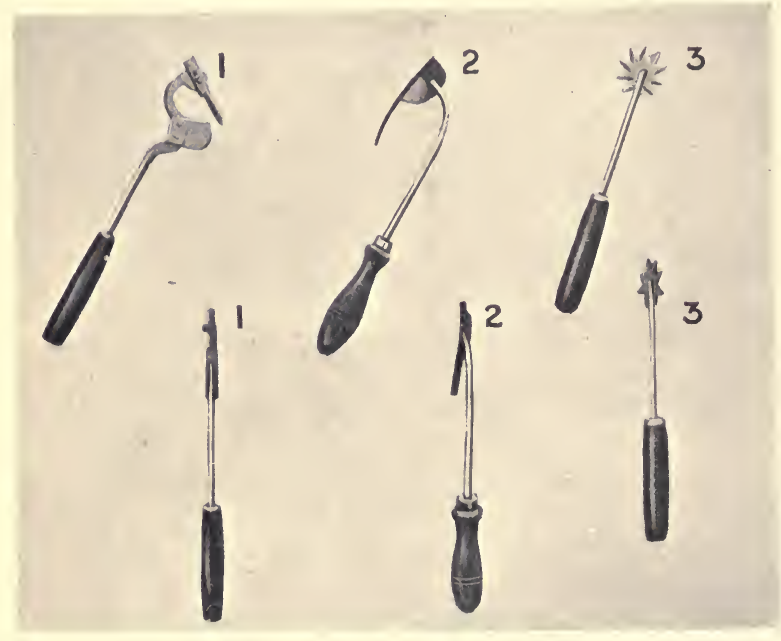

Fig. 7.-The "Bowman-Northway" Tapping Implements.

knives force them to pare over scrap. To prevent this it is best to use knives fitted with a narrow guard, or the guard filed as recommended above to allow for working over scrap. Coolies should be instructed to use both sides of the cutting edges of the knife alternately, cutting from the lowest point up half way or so, and from the top downwards. They should also be instructed to remove shield and cut without, carefully, when knots, \&c., have to be tapped over.

No. 3 knife is a puncturing tool. Its object is to puncture 
the under bark and cambium to cause flow of the latex attracted there by the use of No. 2 knife.

The Michie-Golledge "Tapping Tool" (Fig. 8) is one of the simplest and most effective implements on the market for tapping rubber trees. It is supplied in two sizes, and we have found the smaller size the more useful; it is not difficult to manipulate, and can be expeditiously sharpened. The following particulars given in regard to this, the Macadam "Comb" pricker, and the Miller tapping knife are also taken from Messrs Walker's catalogue.

This tool is perfectly simple in operation and requires no adjustment. It pares from the bottom and side edge of cutting, just the thickness required and no more. It docs first cutting, paring, and channel cutting equally well and clean, and as it admits of the operator reversing his action, it is especially useful for high and low cutting without change of position.

The Michie-Golledge rubber tapping tool should be kept sharp and to the original shape, to ensure the most satisfactory results.

Setting.-To set the tool a small key warding file and a piece of slate is all that is necessary - a fine cutting edge can be put on in a few minutes.

Dressing.-After several months' constant use, it will be necessary to dress the tool, as it is not likely that the cutting edges will get equal wear. To do this, heat the end of the blade to take out the temper and then file the tool to original shape with a small smooth file and then retemper.

This tool is Sheffield made throughout. Length of blacle and shank 6 inches, and beech-wood handle with brass ferrule 6 inches.

The "Miller" knife (Fig. 9) is one of the "simplest" and "safest" 
knives on the market. It is made in one piece only, which in itself is a great advantage. There are four cutting edges, so that the knife can be used as a push or draw tool for paring right or left.

The cutting edges are protected from paring a thicker shaving

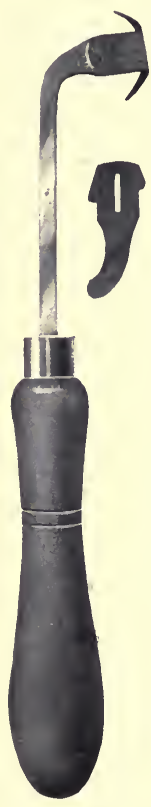

F1G. 9.

Miller's Patent Tapping and Paring Knife. than is necessary, at each tapping operation, by a guard which is part of the knife and which cannot be removed by the operator.

A modified form of the "Christophe" tapping implement (Fig. IO) can be safely recommended, more especially for making the $\mathrm{V}$-shaped incisions and the initial incisions in the spiral and herringbone methods of tapping. This implement is made of metal, and is supplied with three adjustable blades and a movable guide which may be regulated to suit the various thicknesses of bark found on different trees, and thus prevent the tapper injuring the cambium tissue. In our experiments with this knife we have found that the guide confused the tappers, and better results were obtained when it was removed. The smallest size blade is preferred, as the larger sizes cut away an unnecessary amount of bark when making the initial incisions, and are rather too clumsy for shaving off thin layers of bark in subsequent operations.

It is impossible to specify which of the tapping implements on the market is the best adapted for tapping operations, in view of the different methods of tapping in vogue, and the different opinions expressed by planters in regard to the same implement.

One of the cardinal requirements of a good tapping knife is simplicity. Elaborate contrivances for regulating the depth of the incision only confuse the tappers, and, when possible, are removed by them immediately a favourable opportunity occurs. As the depth of the original tappable bark on the trunk varies in different trees from $\frac{1}{8}$ to $\frac{1}{2}$ inch, it is obvious that a standard depth of cutting blade cannot be adopted; nor is it likely that 
native tappers would employ different knives suited to the thickness of the bark of various trees, even were a series of knives specially adapted to the bark requirements of individual trees supplied to them.

Implements for making the first incisions should excise the least possible width of bark compatible with the formation of a sufficient channel to allow the latex to flow down to the collecting vessel. It is essential that this implement should have a keen cutting edge to enable a clean cut to be made without its clogging or drawing and injuring the cortical tissues. Any simple, fixed, or easily adjustable contrivance for preventing undue injury to the cambium tissues during the initial and subsequent tapping operations is also a commendable attribute to a good tapping implement. As it is necessary in the course of tapping operations to make incisions both in an upward and down-

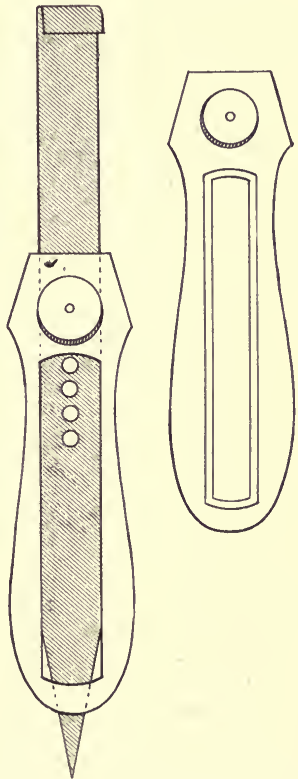
ward direction, and also FiG. I0.--Modified Form of the "Christophe" from left to right, and Tapping Knife. vice versa, the cutting edge should, if possible, be adapted to each of these requirements.

Various instruments have been devised for pricking the laticiferous tissues with a view of taking full advantage of "Wound Response," which will be described later, and to conserve the bark. The use of pricking tools is undoubtedly sound 
policy, providing sufficient labour be available, and the market price of rubber permits of this method of tapping being profitably employed.

The Macadam "Comb" Pricler (Fig. I I ).- This tool is used to slightly prick or puncture the lactiferous cells and thus accelerate the flow of latex without loss of tissue. A steel comb or serrated steel plate is adjusted by a thumbscrew working on a back

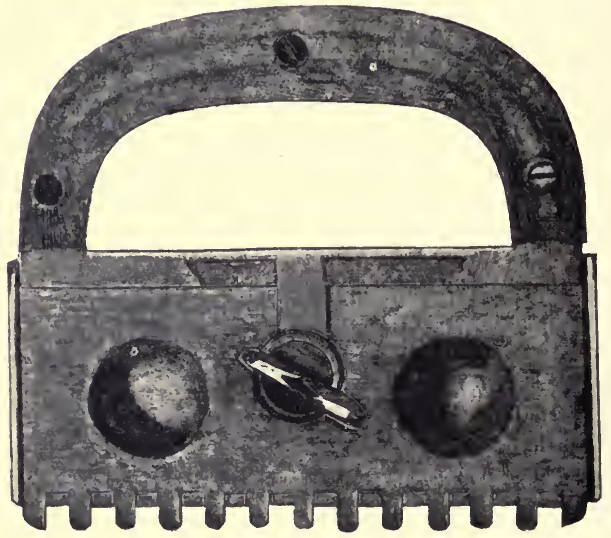

FIG. I I. - The Macadam "Comb" Pricker.

plate and is regulated to a nicety at will of operator. Fitted with double sheaved arch handle. Length of blade, $4 \frac{1}{2}$ inches ; weight, $8 \mathrm{oz}$.

The Laticiferous System of the Para Rubber Tree.

Before reviewing the various methods of tapping in vogue, it will be advisable to study the laticiferous system of the Para rubber tree, i.e., the vessels containing the latex in which the rubber is present.

The majority of the laticifers (latex-containing vessels) in the trunk of the tree are situated just outside the vascular system, i.e., the cambium tissue between the bark and the wood. 
It is therefore evident that an incision should reach this portion, in order to secure a good supply of latex; but it should not penetrate to the wood of the tree, as such a wound takes a long time to heal, and serious damage to the health of the tree is likely to accrue.

The laticifers traverse the bark principally in a longitudinal direction, and with very little lateral communication, so that a transverse incision will tap more vessels than a longitudinal one. Latex is, however, more easily collected from an oblique cut than from a horizontal one, as from the latter it tends to flow over on the bark at more than one point, and some is liable to be wasted; whereas, it is an easy matter to collect latex flowing from an oblique cut by fastening a collecting vessel at the lowest point.

The best time of the day to tap likewise requires consideration, as the flow of latex varies considerably during different periods of the day. In practice, it has been proved that the flow of latex is most copious during the early morning and in the evening, a fact accounted for by some observers by the effect of the sun's heat on the latex.

It is, however, probably due more to the fact that the tension of the plant's tissues varies at different periods of the day, and corresponds to the quantity of water being transpired by the plant.

Transpiration is at its maximum during the early portion of the afternoon, and tension is thereby lessened by the diminishing of the water in the plant vessels; consequently the flow of latex is much slower at this time of day.

Transpiration diminishes during the evening, and the flow of latex is then more abundant, but is, as one would naturally infer, still more abundant at daybreak.

In the Amazon valley, the native collectors never tap the trees when they are in flower, giving as a reason that the amount of rubber then obtainable is much less than at other times; and this curious phenomenon has been proved to obtain in the trees cultivated in the Botanic Gardens, Singapore.

The flow of latex is more abundant during wet weather than in dry, and a heavy shower of rain will materially affect the latex flow on two successive days.

As previously pointed out, the object to aim at in tapping is 
to obtain a maximum amount of rubber from a tree at a minimum cost, and at the same time inflict a minimum amount of injury to its vitality.

\section{Flow of Latex InCREased by Wounding the Tree.}

Tapping experiments prove that the amount of latex yielded generally increases day by day until about the seventh day, and then gradually decreases; but the length of the period which must elapse before the maximum yield is obtained will naturally vary considerably in different places, and even trees on the same plantation behave differently.

In some cases the maximum yield is obtained as early as the third day, but in other cases not until the fourteenth.

The extraordinary manner in which the flow of latex is accelerated by wounding the tree is well known to the native collectors in Brazil, who state that the rubber trees do not yield satisfactorily until they are "accustomed" to being tapped, Wounding increases the flow of latex towards the injured portions. so that it is advisable that successive tappings should be adjacent to preceding ones, in order to take advantage of this curious phenomenon.

\section{WHEN TO "TAP."}

Tapping should take place either during the morning or the evening, but preferably during the morning, as the flow of latex is then more abundant. On no account should tapping take place during the heat of the day.

Before commencing operations the trunk of the tree must be thoroughly cleared of all dirt, loose bark, or plant growths, to a distance of 6 feet from the ground.

Mr Ridley reports* that he was informed by M. Bonnechaux, a man of great experience in the rubber business of the Amazons, and who had spent some time among the Serengueiros investigating their methods and collecting notes and observations on all subjects connected with Para rubber, trees there are tapped for Iso days continuously and then allowed to rest for six 


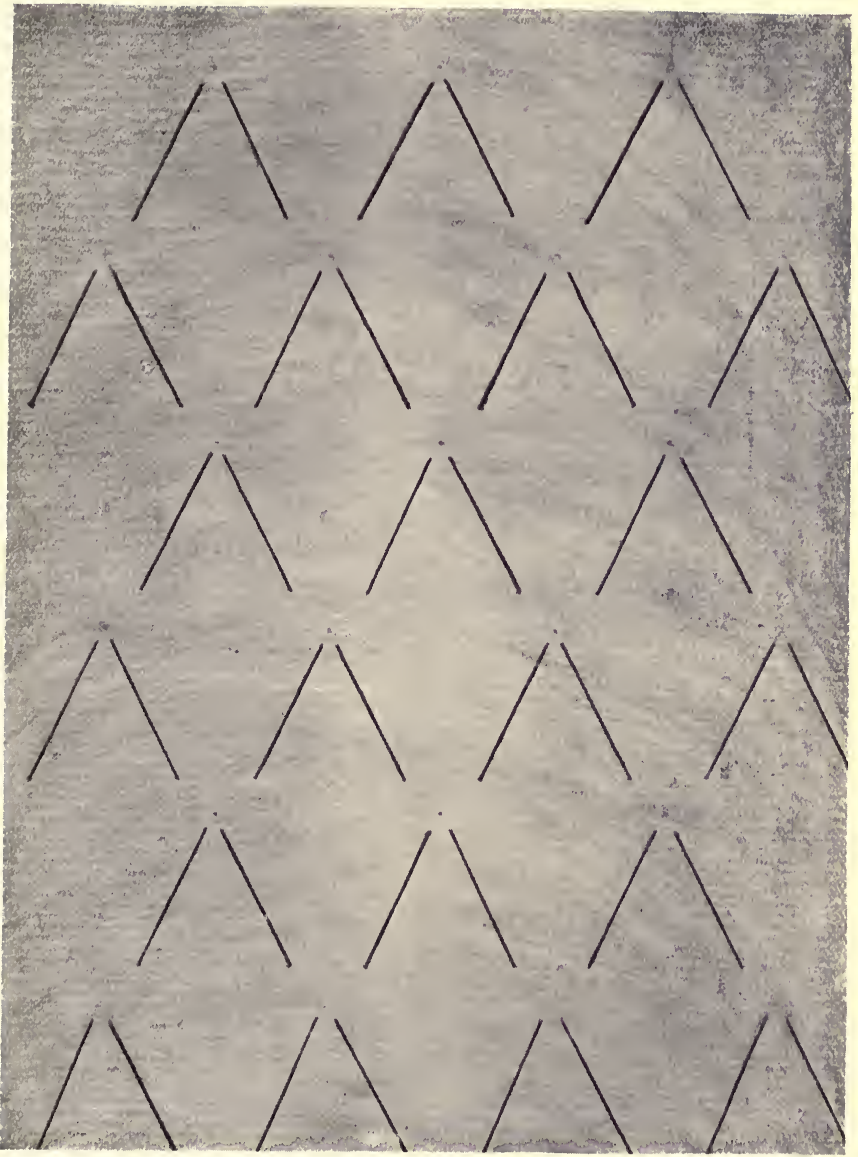

FIG. 12.- Relative Size and Position of V-Incisions (about one quarter natural size). 

months, and seem so little the worse that he (M. Bonnechaux) declares he knows of trees which had been tapped thus for eighty years. The same writer states* that trees have been tapped off and on during fifty years, and still yield a plentiful supply of latex.

It is impossible to lay down any hard-and-fast rules regarding the time which should elapse between each successive tapping, as this must necessarily depend upon the amount of damage done to the trees by tapping and their general health. "It is not so much the loss of latex which is injurious to the tree as the amount of wounding required to obtain it.

\section{V-SHAPEI INCISIONS. \\ "isure}

What is known as the $\mathrm{V}$ method of tapping is the one which was first generally adopted by Ceylon planters.

On commencing operations, a row of $\mathrm{V}$-shaped incisions is made in the trunk of the tree at about 6 feet from the ground. The sides of the V's are about 6 inches long, and about the same distance apart at the open end. A space of 5 or 6 inches is left between each $\mathrm{V}$.

A small vessel, usually made of tin, about 2 inches by 2 inches and capable of holding about 6 ounces of latex, is fixed at the apex of the $\mathrm{V}$ to collect the latex by pressing the edge of the tin into the bark. On the following day another row of similar incisions is made 5 or 6 inches below the last, and so on each succeeding day until the base of the tree is reached. A second series of similar incisions is then made within the first, commencing at the top row ; this is continued as before, one row each day, until the base of the tree is again reached. Sometimes a third and even a fourth series of inner V's is made. But the extent of tapping is regulated by the size of the trees operated on, and the quantity of latex obtainable. On some estates the trees are tapped once and on others twice a year.

A modification of this method suggested by the writer in 1904 in the first edition of this work is as follows :-

A row of incisions similar to those shown on Fig. I 2 should be made round the trunk of the tree about $I_{2}^{1}$ inch apart, and at

* Straits Settlements Agricultural Bulletin, Dec. I90I. 
about 6 feet from the base. The sides of these incisions should not exceed 3 inches in length, nor be nearer than 3 inches apart at the top. It is essential that they do not quite meet at the base, as pieces of bark are liable to be broken off by the junction of the cuts. Directly an incision has been made, a collecting vessel should be fixed at its base to collect the latex, which commences to flow almost immediately the tree is wounded. It is advisable to place a small quantity of water in each vessel to prevent the latex coagulating before it is taken to the curingroom.

On the following day a second row of similar incisions should be made about I inch below the previous incisions, but alternating with them, and this should be repeated on each succeeding day until the base of the tree is reached.

Tapping, according to these directions, limits the period of tapping to seventeen or eighteen days.

The period during which Para trees are tapped on many estates frequently extends much longer than this, but I am of opinion it is much safer to tap a tree lightly and at fairly frequent intervals than to practically drain it at one tapping.

Latterly, $\mathrm{V}$ tapping operations have been further modified by shaving away the bark from the lower surface of each side of the $\mathrm{V}$.

Where due care was observed to prevent injury to the cambium and wood the trees have suffered few ill effects from this method of tapping. The amount of labour required in connection with the fixing, emptying, cleaning, \&c., of the large number of collecting cups which this method involves is doubtlessly one of the principal reasons why it has been largely superseded during recent years by other tapping methods.

\section{Herring-Bone Shaped Incisions.}

Native rubber collectors in the Gold Coast Colony have tapped indigenous trees (Funtumia elastica) by means of herringbone shaped incisions for the last thirty years. The method first generally adopted by the planters in the Malay Peninsula for the extraction of rubber from their Hevea trees is known as the herring-bone system of tapping, and it is probably the one most generally adopted for tapping cultivated Hevea trees at 
the present day. ' It consists of a central channel which may vary in length from I to 6 feet, into which shorter oblique incisions, alternating with each other on either side of the central channel, lead at an angle of about $45^{\circ}$ and at distances varying from 9 inches to I foot apart. Subsequent operations consist in shaving the lower surface of the oblique incisions at varying intervals of time until the whole of the bark between the oblique cuts has been pared away.) An objection to this method of tapping is that the amount of latex obtained from the excision of bark for the perpendicular channels is not commensurable with that yielded by the same amount of bark excised in an oblique direction, for the reasons previously explained. On the other hand its adoption effects a considerable saving of labour as compared with the $\mathrm{V}$ method, as it is only necessary to place one collecting vessel at the base of each vertical channel.

Some planters prefer to excise all the bark from one side of the perpendicular channel before commencing to tap the opposite side. Others elect to divide up the trunk of the tree into three or four divisions and excise all the bark from each division in rotation. Whichever modification of this system of tapping be adopted, its drasticity will obviously largely depend upon the care taken to protect the cambium and the wood, the quantity of bark pared away at each operation, and the period of time allowed to elapse between successive tappings.

\section{SPIRAL INCISIONS.}

What is known as the "Full Spiral" (vide Fig. I 3 ) is considered one of the most drastic methods of tapping yet evolved, but yields the largest amount of rubber in a specific time. This method of tapping is also reported to have been employed by Nicaraguan rubber collectors more than thirty years ago. Briefly stated it consists in making a series of spiral, parallel, incisions, about I 2 inches apart, round the trunk; these usually commence at a height of $\sigma$ feet from the ground and end at the base of the tree.

The number of incisions on any particular tree is consequently regulated by the circumferential measurement of the trunk at the point where operations commence. Subsequent tappings are effected by shaving the bark off the lower side of the incisions. 
It will thus be seen that the employment of this method likewise considerably reduces the work in connection with collecting cups as compared with the $\mathrm{V}$ method.

Spiral incisions were much in vogue a few years ago, and enormous yields were obtained, but this was, in the majority of instances, at the expense of a disproportionate amount of bark.

On several estates the whole of the bark up to a height of 6 feet from the ground was pared away in one season. Such rapid excision of the cortex can only be regarded as pernicious to the tree's vitality and must adversely affect its future yield. Assuming that trees seven years old be tapped for the first time by this method, bark which has taken seven years to develop is demolished in one year, and it is unlikely that the new one-year-old bark will be as productive as that which it replaced. Such rapid excision is not by any means essential when spiral tapping is adopted, as the original bark on some estates, where this method is employed, is estimated to last for three years.

To ensure the incisions being made at the proper distances apart, and at the necessary angle, the positions for the initial incisions should be marked. Cut a piece of tin or similar substance in the form of a right-angled isosceles triangle, the side subtending the right angle being 2 feet long and the two equilateral sides i 7 inches long.

This guide should be pressed flat against the trunk at the height it is intended to commence operations, one of the equilateral sides being at right angles to the trunk, the line for incision being inarked along the hypotenuse. By carefully removing and adjusting the guide, this line may be continued to the base of the tree. The line for the second incision may then be marked by placing the apex of the right angle of the guide at the origin of the first line, one equilateral side being parallel with the trunk and the other uppermost; the hypotenuse then indicates the correct direction for the second incision, which may be marked as suggested with regard to the first one. It will be now patent that a tree under 34 inches in circumference, at the height from the ground above which it is not proposed to tap, will only have one spiral incision, or in other words, one spiral incision may be made for each 17 inches of circumference at the height indicated. 


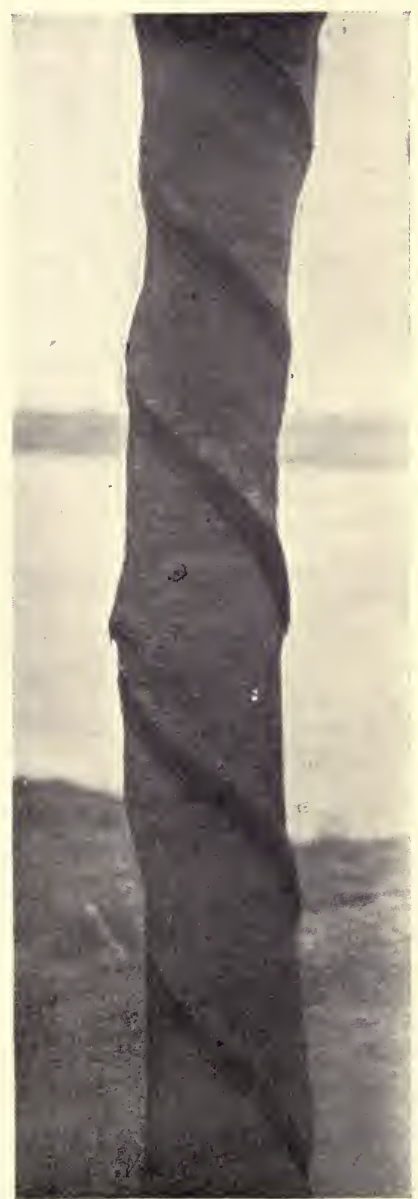

FIG. 13.-Spiral Tapping.

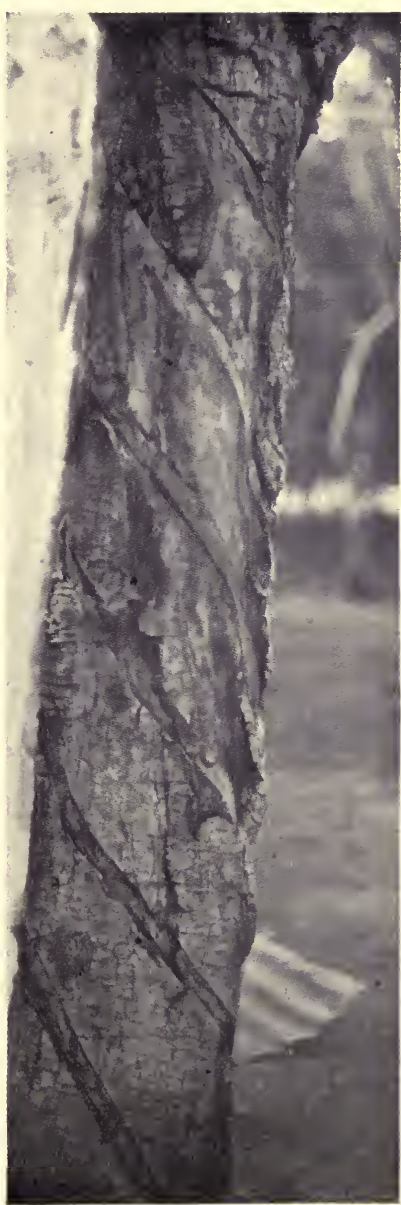

FIG. I 3 A.-Injurious Effect of Careless Tapping. 

The "Full Spiral" method of tapping has latterly been condemned by some planters on the ground that it is too drastic and too difficult of accomplishment by untrained coolies. See injurious effect of careless tapping (Fig. I3A).

Another form of spiral tapping is conducted as follows: A vertical channel is cut for every 17 or 18 inches of the trunk circumference; spiral curves, each 2 feet long, are cut leading into the vertical incision at a foot apart, the lower side of the spirals being afterwards shaved away as in the full spiral method. The isosceles-triangularly shaped guide can also be used for marking the initial curved incisions by arranging one of the equilateral sides parallel with the vertical channel. The hypotenuse again indicates the direction of the curve, the junction of each with the vertical being regulated at I foot apart.

As with the herring-bone shaped incisions, it is only necessary to have one collecting vessel at the base of each vertical incision. A permanent spout may be fixed at the base of the latter to lead the latex into the collecting vessel, and obviate the injury caused by pressing the collecting cups into the bark which the tapping by V's and similar methods entails.

What may be described as the "Half Spiral " tapping method may for all practical purposes be considered as identical with that last clescribed, except that the vertical incisions are dispensed with. It entails the use of a larger number of collecting cups, as a separate vessel is required to be fixed at the base of each curve in order to collect the latex.

This extra labour is, however, in a measure compensated for by the large yield in comparison with the amount of bark excised.

\section{PRICKING.}

With a view of conserving the bark, implements such as the Bowman-Northway puncturing tool marked No. 3 (Fig. 7), and the Macadam comb pricker have been used alternately with paring implements, and it has been stated that, comparing the yicld of rubber with the amount of bark excised, the yield has been enhanced. The idea is to puncture the latex-bearing vessels near the cambium. It is found, however, that when this puncturing method is resorted to, the flow of latex from the succeeding paring is appreciably diminished. The importance 
of economising the bark by such methods cannot be lightly estimated, but it seems extremely doubtful whether they can be profitably employed except when the price of rubber is abnormally high.

\section{VARIOUS METHODS.}

Where the bark of trees is too corrugated or knotty for the herring-bone or-spiral system to be employed, short oblique or zigzag incisions can be made with advantage.

\section{GENERAL REMARKS ON TAPPING.}

Notwithstanding the numerous experiments conducted, apparently with a view to determine the best tapping method, few are of any real value to the practical planter, as the cost of tapping, collecting, and preparing the rubber is not stated, nor even the number of labourers employed in connection with these experiments. It is of comparatively little utility to the planter to learn that a given number of pounds of rubber have been obtained by the adoption of a particular method of tapping and the excision of so many square inches of bark. What is more important for him to know is the method by which he can collect the maximum amount of rubber at a minimum cost, without unduly injuring his trees. It is obviously impracticable to risk the adoption of methods of tapping which entail the expenditure of a larger sum for labour than the marketable value of the rubber obtained.

All persons interested in the cultivated rubber industry must appreciate the scientific value of some of these experiments. It may, of course, be argued that the planter could ascertain this for himself, but he rarely has either time or labour available for this purpose.

At the present stage of the rubber planting industry it is impossible to state which of the tapping systems in vogue is the best, nor whether the best system has even been discovered.

There is a vast difference of opinion as to whether some of the first adopted tapping methods, such as the $\mathrm{V}$, will not prove more profitable than those more recently evolved, which necessitate the excision of the whole of the bark from the tapping area. The rapid destruction of the original bark which is so frequently 
associated with the last-mentioned systems is certainly open to serious criticism. In a large number of cases the whole of the bark from this area has been excised away in one year. It is perfectly unreasonable to expect that bark, one year old, will yield rubber equal in quantity and quality to that produced by the original bark.

Latex is quickly renewed in the bark, but the production of a good percentage of caoutchouc in the latex takes a much longer time. As previously pointed out under the heading "Latex," in one instance the percentage of water in the latex, obtained from renewed bark, was 90 per cent., whereas latex from the original bark contained only from 30 to 50 per cent. of water. Obviously, then, planters should endeavour to regulate their tapping operations in such a way that the old bark is not pared away until the new bark with its contents is mature. It should be borne in mind that the fusion of cells is going on daily in the secondary cortex by the breaking down of transverse walls, therefore the greater the age of the bark, under ordinary conditions, the greater the number of laticifers.

With due care an inch of bark need only be cut away after from twenty to thirty parings have been made, so that it should be possible to tap a given tree seventy-five times a year and still take advantage of wound response. Excising the bark at this rate, it would not be necessary to tap the renewed bark until it was four years of age.

Tapping is only carried out during one season in the Amazon, and it is possible that, if tapping of cultivated trees were suspended for several months, especially during the resting season, better results would be obtained.

\section{Collecting Vessels, \&c.}

Vulcanite or aluminium vessels should be preferably used for collecting and transporting the latex, to those manufactured of iron and tin, as the latter become coated with rust with which the rubber is liable to become contaminated.

With a view to encourage the flow of latex down to the collecting vessels and consequently lessen the production of scrap rubber, the use of an invention known as the drip-tin has been suggested. 
This apparatus is made with a concave surface on one side to enable it to fit the bark of the tree. It is fixed by means of pins immediately above the top of an incision in such a manner that a weak solution of ammonia or formalin placed therein drips
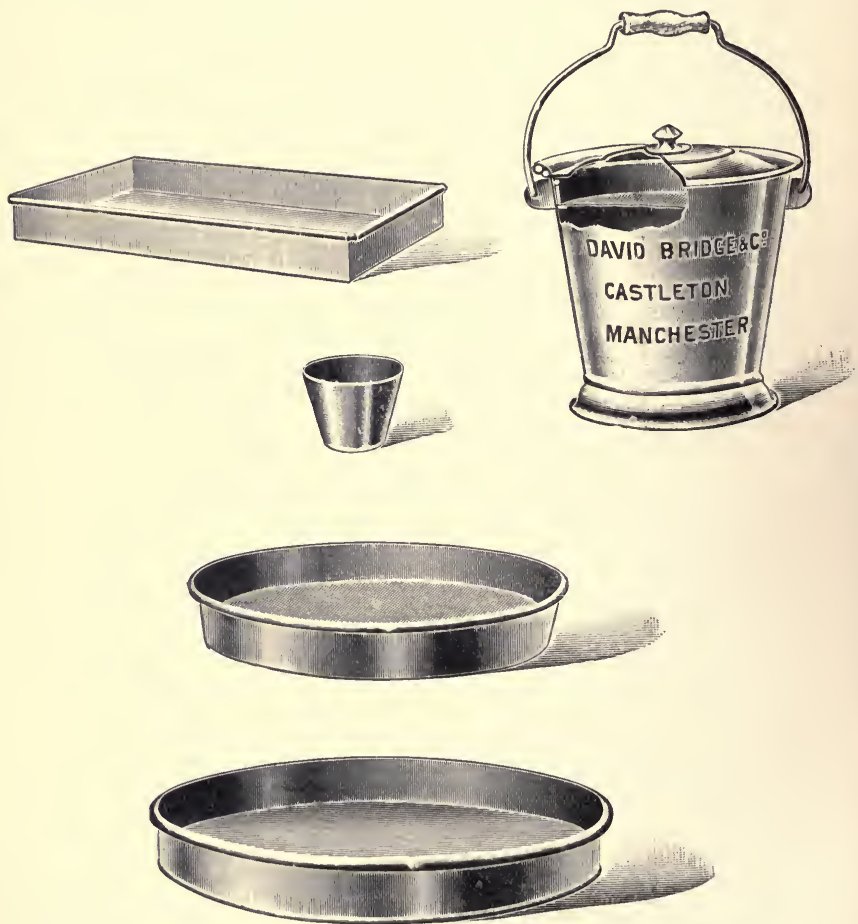

FIG. I4.-Oblong and Round Coagulating Pans, Collecting, Cup, and Pail with Strainer.

from an outlet at its base down the newly pared incision. The rapidity of the flow of the solution is regulated by means of a screw arrangement connected with this outlet. The object of the added chemical is to prevent the coagulation of the latex in 
the channels and consequent blocking of the tapped laticiferous tubes.

Theoretically the adoption of such an apparatus is excellent, but it has not been generally profitable in practice. A similar remark applies to an elaborate contrivance manufactured for the purpose of conveying the latex from several trees to one collecting point.

TAPPING AREAS.

Although latex is found both in the trunk, branches, and leaves of the Para rubber tree, the 6 or 7 feet of the trunk

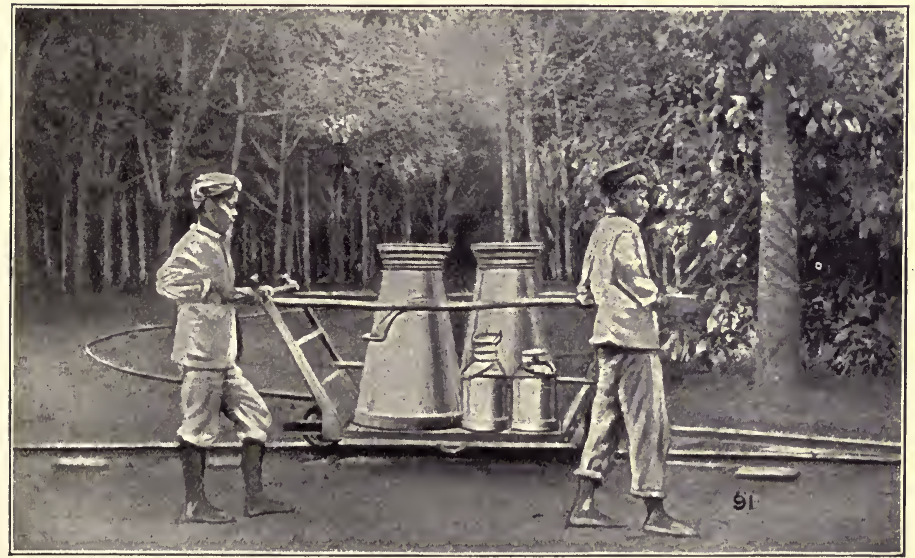

F1G. I 5.--Caillet's Monorail, recommended for facilitating transport on Rubber Estates.

nearest the ground is the principal portion operated on for the collection of latex. Obviously, it is the most accessible portion of the tree, and, as it has been previously mentioned, judicious pruning of the young trees will materially encourage its development.

Marquart, d'Esembeck, and Nees found caoutchouc in the trunk of the Ficus elastica trec, but ascertained that its place was taken by viscine in the latex of the leaves and branches of the 
same tree. Adriani, who investigated the latex of the same species, discovered that the percentage of solid matter was less in the latex obtained from the higher and younger parts of the tree than in that obtained from the parts nearer the ground. He also found that the caoutchouc globules in the latex obtained from the young growths were smaller than those in the latex yielded by older parts. Burgess found the percentage of rubber in latex collected from the first 2 feet of the trunk of the Para tree nearest the ground, and that of latex obtained at a height of 20 feet from the ground, to be 44.4 and 39.8 respectively, while latex from a large exposed root contained 43.8 per cent: of rubber.

Generally speaking, the rubber obtained from the higher parts of the Para tree is inferior in quality to that obtained from the trunk nearer the ground; incisions made in the last mentioned region are certainly most productive of rubber.

Fig. 15 shows Caillet's Monorail system manufactured by Messrs Francis Shaw \& Co., in operation on the Lanadron Estate, Muar, Johore. This system greatly facilitates the transport of latex, manures, rubbish, \&c., on rubber plantations. 


\section{CHAPTER X.}

\section{RUBBER MANUFACTURE.}

\section{Properties of Rubber.}

BEFORE dealing with the various methods of preparing rubber from the latex, let us endeavour to describe some of its physical and chemical properties. No other solid body can be compared with it in regard to elasticity, which may be augmented by slightly raising its temperature. When the temperature is lowered to zero it becomes hard and brittle, but regains its elasticity on the temperature being raised. If, however, this be increased to $293^{\circ}$ Fahr., it assumes a permanent sticky consistency, while, if the temperature be still further raised to $360^{\circ}$ Fahr., it melts and turns to a dark oily liquid. Rubber is a bad conductor of both heat and electricity, but when acted upon by oxygen, ozone, or light, it may be converted into a good conductor of both these forces. It has the power of expanding when heated, and contracting when submitted to a lowered temperature. If, however, raw rubber be raised to a temperature of about $240^{\circ} \mathrm{Fahr}$. and then allowed to cool slowly, it loses all its powers of contractility, but no perceptible changes are produced in its other properties. It is upon this characteristic that the rubber thread industry is largely dependent. Rubber is extremely permeable towater, and this fact is often taken advantage of for fraudulent purposes. It is compressible, and Blossom states that a blow of IOo tons diminished the volume of a cube of rubber, of about 35 inches square, by Io per cent. Beadle and Stevens state that ${ }^{*}$ the physical properties of raw rubber are improved by exposure to comparatively low temperatures. They found that samples of block plantation rubber placed in an ice-chest for a week showed a tensile strength of 780 as against 500 previous to being placed in the ice-chest. 
Rubber is insoluble in water and also in alcohol, but light coal-tar naphtha, petroleum, spirits of turpentine, carbon disulphide, ether, benzol, fatty and essential oils cause it to swell, and to a certain extent dissolve it. Gerard states that the best solvent is a mixture of 100 parts of carbon disulphide and $5 \frac{1}{2}$ per cent. of absolute alcohol. Strictly speaking, rubber is only partially soluble, as it consists of two substances which have different properties, one of which is easily dissolved; the other being of a tough elastic consistency which persistently resists nearly all solvents. Seeligmann distinguishes these two isomeric substances as the nervous and adhesive principle respectively. Spence states: * "From my early experiments to determine the amount of the insoluble constituent in raw Para rubber, I came to the conclusion that there was upwards of 8 to ro per cent. of the product in most samples of raw Para. Later investigation, using chloroform as solvent and extracting over a much longer period, convinced me that my previous observations were wrong. I had not extracted the caoutchouc completely, and, repeating one or two of the analyses, I found that the amount of the insoluble constituent could be reduced to 2 per cent. in samples in which I have previously found about 8 per cent." And in reference to the nitrogen content of the soluble residue: "The highest value obtained was that for a sample of the insoluble product which had been extracted with chloroform for about three months. It has already been given ( 5.4 per cent.) and represents at least 33 per cent. of protein in the original product."

In regard to the complaints about the want of "nerve" in plantation Para as compared with that in the Amazonian product, Beadle and Stevens write $: \dagger$ "The truth of the matter is, that up to now few manufacturers have taken the trouble to give plantation rubber a fair trial. Rubber of such purity has never before been put on the market, and requires mastication and vulcanisation under modified conditions. These conditions we have only discovered after a great deal of experimental work; and we confidently assert in spite of nebulous talk about

* Quarterly Journal, Institute of Commercial Resurch in the Tropics, Liverpool University.

+ India-rubber Journal, p. 321, 7th Oct. 1907. 
want of 'nerve' and adverse opinions of a few manufacturers, that when the right conditions are applied, nothing equals the best dried plantation block mixed and vulcanised without previous treatment."

Analyses of Para rubber produced in various countries are given below :-

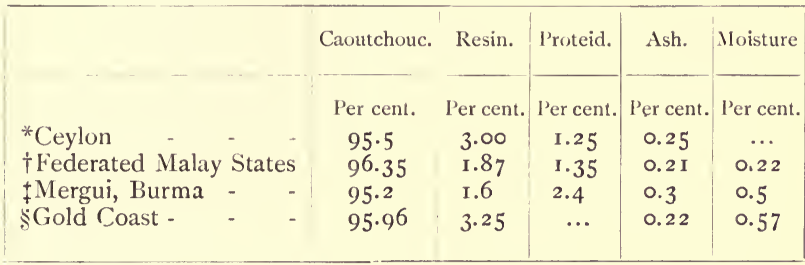

* Tropical Agriculturist, Nov. 1904.

+ Bulletin, Imperial Institute, vol. v., No. 3 .

† Bulletin, Imperial Institute, vol. v., No. 4

" "Report on Rubber in the Gold Coast," 1904, Johnson.

\section{Caoutchouc.}

The percentage of caoutchouc in rubber prepared from cultivated Para trees varies from about 92 to 96.35 per cent. There appears to be practically little difference in the caoutchouc content of rubber prepared from trees varying in age from four to thirty years as shown by the following figures quoted by Kelway Bamber:-

$$
\begin{aligned}
& \text { Para Trees, } \\
& \text { Age in Years. }
\end{aligned}
$$

$\begin{array}{cc}4 & - \\ 6 & \\ 8 & - \\ 10 & \text { - } \\ 30 & \text { - } 2\end{array}$

\section{Percentage of Caout-} chouc in Rubber.

$$
\begin{array}{r}
94.5^{8} \\
-\quad 94.75 \\
-\quad 94.60 \\
-\quad 94.35 \\
-\quad 93.24
\end{array}
$$

\section{RESIN.}

The same chemist found very little difference in the percentage of resin in rubber obtained from cultivated Para trees from four to thirty years of age, this being 2.72 and 2.32 in the 
first and second instance respectively. This is rather surprising, as the weakness and susceptibility to tackiness so frequently associated with rubber produced by young trees have often been attributed to its high resin content.

\section{Proteids.}

He found the amount of albuminous niatter in rubber prepared from four-year-old and thirty-year-old trees to be 1.75 and 3.69 per cent. respectively. It has been frequently suggested that as these albuminoids are largely responsible for the putrefaction which sometimes occurs in rubber, that they should be eliminated from the latex. It, however, seems doubtful whether this would be a wise policy. Spence states :* "That the distribution of the protein mass in the form of a tough fibre running throughout the caoutchouc mass would greatly increase the tensile strength of the latter it seems quite reasonable to suppose, in which case endeavours should be made to secure, by coagulation methods in plantation rubber, just such a distribution of its protein constituents as has been shown by the present work to exist in Hevea rubber from South America."

\section{Mineral Matter.}

Both potassic and calcic organic salts are, according to Seeligmann, loc. cit., found in Hevea rubber, but as the total constituents in the ash rarely exceeds .4 per cent. of the whole product they may be considered as negligible quantities except for their assistance in the identification of particular grades of rubber by chemical analysis.

\section{EHFECTS OF VULCANisAtion.}

In view of the comparatively small market for unvulcanised rubber goods the real value of rubber depends principally upon the properties of the vulcanised product. As different samples of rubber are differently affected during this process it is only possible to determine their strength, power of resistance,

* Quarterly Journal, Institute of Commercial Rescarch in the Tropics, Liverpool University. 
resiliency, and therefore their value for specific purposes, after vulcanisation.

Experiments conducted by Ditmar, to test the effects of resin on the vulcanisation of rubber, tend to show that, provided the resin content of rubber does not exceed 7 per cent., it has no injurious effect upon the vulcanisation of rubber; but that the strength of rubber is considered to be diminished and exhibits a marked tendency to oxidation by containing a higher percentage of resin.

Beadle and Stevens state :* "Now without denying the existence of a correlation in properties between a sample of caoutchouc and vulcanised rubber prepared from it, it must be remembered that the properties of caoutchouc are profoundly altered by vulcanisation, and the properties of the vulcanised product are largely within the control of the manufacturer. For this reason we should rather interpret the word 'nerve' to be an expression applied to those physical properties of caoutchouc which are preserved in the vulcanised product. It is evident that whatever excellent qualities raw rubber may possess, these will be valueless unless they outlive the vulcanising process."

On arrival at the manufactory crude rubber is immersed in hot water for periods varying between ten and twenty-four hours. It is then passed through heavy iron grooved rollers over which a constant supply of water flows. The rollers revolve at different rates of speed which tears the rubber to pieces and the water washes away mechanical impurities such as sand, dirt, bark, \&c.

The loss in weight which rubber suffers in this process varies from I to 3 per cent. in plantation Para rubber to as nuch as 60 per cent. in inferior grades.

The rubber is eventually turned out in sheets resembling in structure the lace plantation rubber which will be referred to later. These are usually hung up to dry in well-ventilated, darkened, artificially heated drying rooms. Vacuum drying apparatus is also used for this purpose.

The temperature is, however, regulated in accordance with the class of rubber under treatment, as inferior grades of rubber, which contain a large percentage of resins and similar bodies liable to be affected by heat, would soften and melt if exposed

* India-rubber Journal, p. 321, 9th Sept. 1907. 
to temperatures as high as those to which the superior grades such as "Fine Para" are subjected. When thoroughly dry it is stored, but well protected from light and moisture till required for manufacturing purposes.

Previous to manufacture the lace-like sheets of rubber are masticated into a homogeneous texture by being passed between large hollow steam-heated rollers.

Owing to the various defects of raw rubber for industrial purposes, it will be evident that its use would have been considerably limited had it not been for the discovery of the various methods of vulcanisation, which consist in causing masticated rubber to be intermixed with various proportions of one of the different forms of sulphur by the action of heat. At normal temperatures sulphur has, however, no visible effect upon rubber.

\section{Preparation of Rubber from Latex.}

The preparation of rubber from the latex is one of the most important points which the rubber planter has to consider, as the commercial value of the product will largely depend upon the manner in which this has been carried out. The low price obtained for many grades of rubber is due, in a great measure, to careless preparation.

The West African rubbers afford striking examples of this kind. They are often contaminated with dirt, stones, bark, \&c. ; spurious latices are added to good ones, and the resulting mixture is often a "tacky," putrescent mass, giving out a most offensive odour.

Quite a few years ago Congo rubbers only realised from Is. to Is. $6 \mathrm{~d}$. per lb., but now that they are more carefully prepared they often fetch $4 \mathrm{~s}$. per lb.

The methods in use in different parts of the world for the coagulation of rubber from latex are exceedingly numerous and varied.

Coagulation may be effected by heating the latex, or by adding either an acid or alkaline solution, while the latex of some trees may be coagulated by simply exposing it to the atmosphere.

Whichever method be employed, the nitrogenous matter in the latex is coagulated, and the rubber globules are carried down 


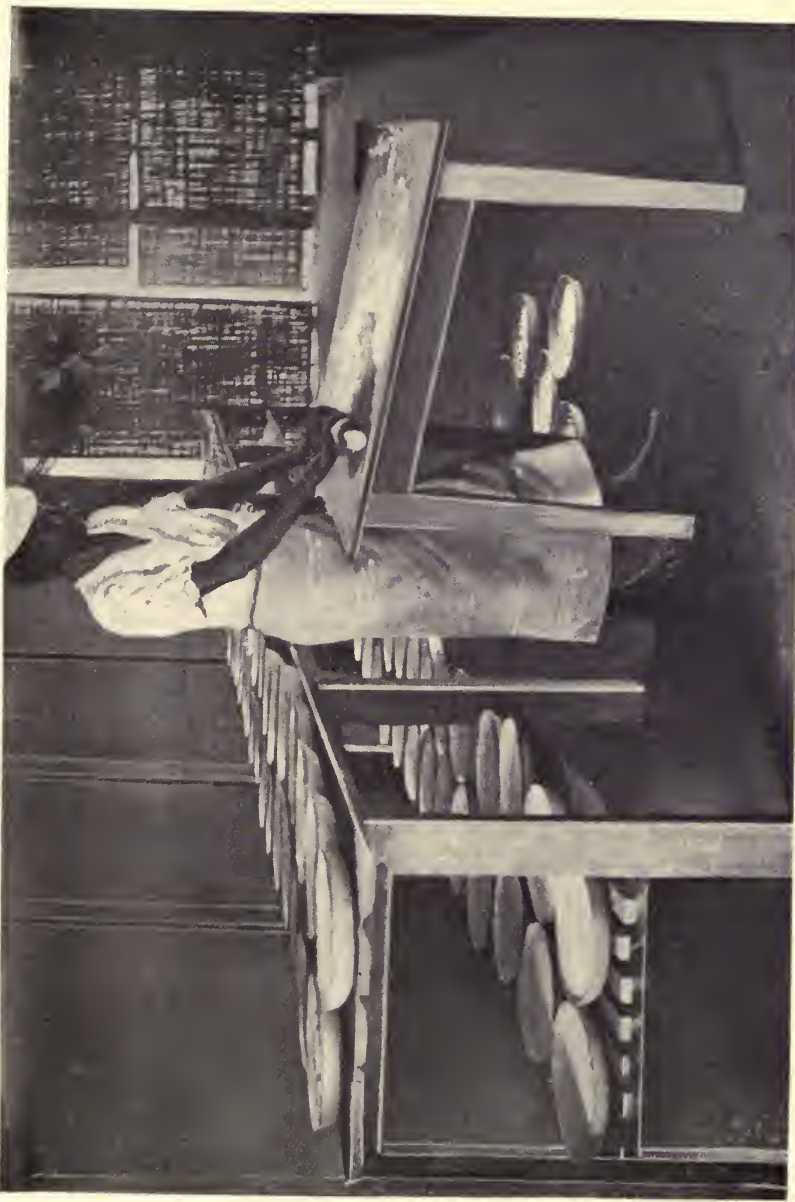

(1)

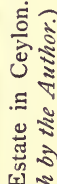

되 중

तี

ㄷำ

in

.$\stackrel{3}{2}$

U

की

t)

를

旅

$\Xi$

$\frac{0}{1}$

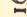

红 

intermixed with it, the coagulum forming a solid, white in appearance, and quite distinct from the apparently homogeneous mass of which it previously formed a part.

In Mexico and Central America the latex of Castilloa is boiled, and the rubber rises to the surface, resembling that formed on animal milk when similarly treated.

The collectors in the Amazon valley prepare rubber from Para latex by submitting it to the smoke of burning Urucuri palm nuts, which contains acetic acid and creosote.

The West African natives prepare rubber from the latex of Funtumia elastica by adding to it either the juices of various plants having acid properties or salt water, and from the latex of the Landolphia vines by smearing it over their naked bodies, where the rubber is coagulated by the secretions from the skin, or by treating it with lime juice.

The principal acid coagulants employed on rubber plantations are: acetic, sulphuric, hydrochloric, nitric, oxalic, citric, and tartaric. Of these, sulphuric acid is the most powerful coagulant, and citric acid is the weakest.

The commonest alkaline coagulants are: mercuric chloride (corrosive sublimate), sodium chloride (common salt), and alum.

If an excess of either an acid or an alkaline solution be applied to the latex no coagulation occurs, and the requisite quantity of any coagulant varies in direct proportion to the amount of pure latex present; however much a given quantity of latex may be diluted with water, the amount of the coagulant required to bring about coagulation will remain constant.

Quite recently Biffen discovered that the rubber in latex could be separated from the other constituents by centrifugal force. This process is quite distinct from coagulation, as by centrifugal force the rubber globules are separated in a like manner to cream when animal milk is churned, and their composition is not altered.

“Rubber prepared by this method is reported to lack 'nerve,' and there is a very remarkable difference in the vulcanisation results obtained with coalesced and coagulated rubber respectively. The difference is certainly not in favour of the coalesced rubber" *

* India-rubber Journal, 23rd June 1902. 
The following is the oldest method adopted in the preparation of Para rubber on some of the rubber estates in Ceylon :-

Immediately the latex is brought in from the plantation it is strained through fine wire or muslin gauze, the latex being diluted with water if it is too thick to pass through freely, and poured into enamelled iron saucers about I foot in diameter, and $I_{2}^{1}$ inch deep.

Coagulation occurs spontaneously within twenty-four hours if the latex be exposed to the atmosphere. But if it be wished to hasten the process, acid is applied; acetic being one of the commonest employed. The coagulum is then submitted to pressure, in order to free it from as much moisture as possible. A metal roller, similar in shape to that used for culinary purposes, is generally employed, and in the manner shown in Fig. I6. This process converts the rubber into flat discs, which vary in thickness from an eighth to half an inch, and about a foot in diameter. These are then usually submitted to a little artificial heat, and afterwards spread out singly on shelves in a well-aired room until thoroughly dry.

Fig. I 7 shows rubber biscuits spread out to dry in a curinghouse on the Aropolakande Rubber Estate, Ceylon.

The rubber planters in the Malay Peninsula adopted a very similar method to the above.

Dr O. Weber, ${ }^{*}$ who devoted considerable labour to the chemical questions relating to india-rubber, suggested the following process to eliminate putrescible nitrogenous matter from latex :-

"The first step in this direction is the dilution of the crude latex with water, of which at least five times the volume of the latex treated should be used. In the case of the thick, ready latex yielded by the trees at Las Cascadas it is preferable to use actually boiling water, but in how far this applies to the latex obtained in other districts or from different trees is a matter for experiment. Boiling water at once converts this latex (i.e., Castilloa) into a thin, very fluid milk, which through a common cotton gauze is strained in order to remove from it any insoluble impurities, such as earth, wood, bark, and the like. This milk is best strained into thoroughly well-washed petroleum barrels. As soon as the 


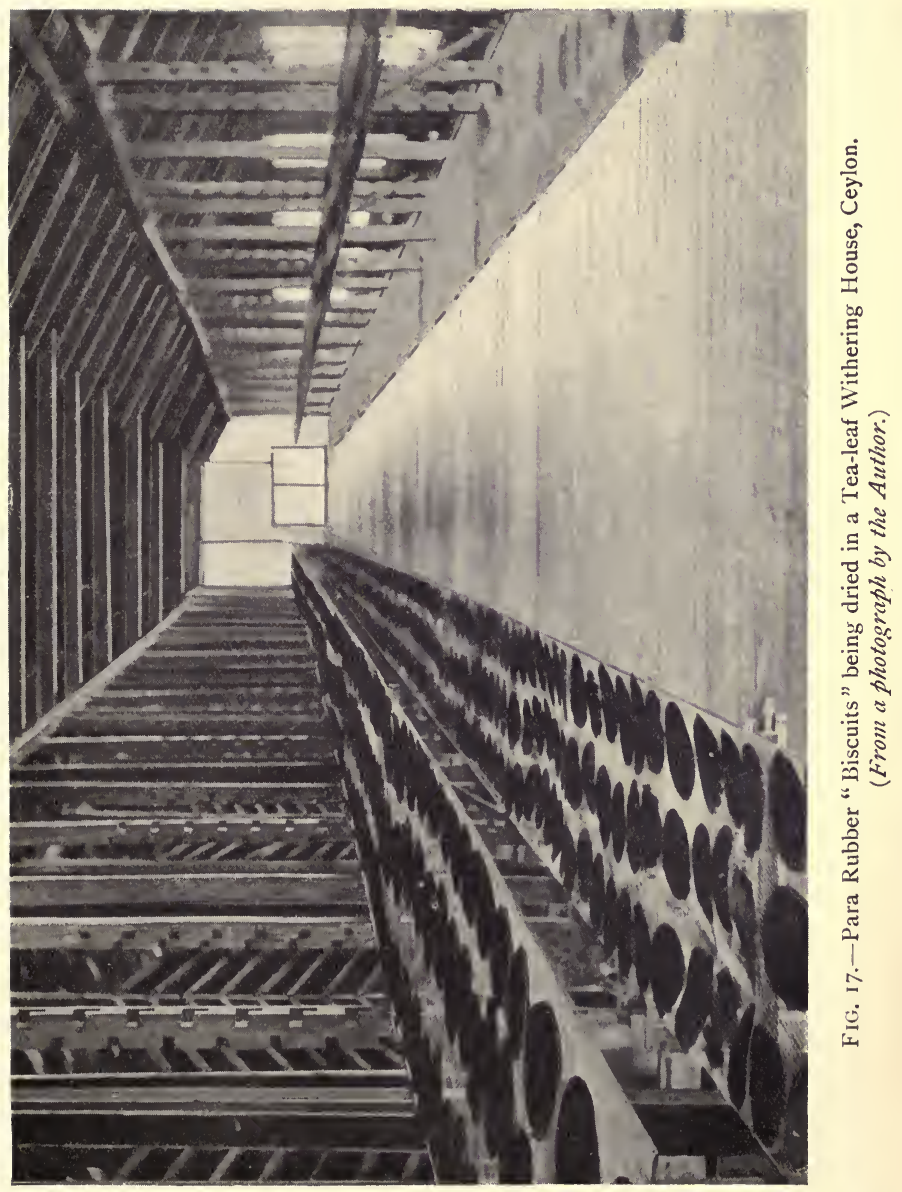



barrel is completely filled, about eight ounces of formaldehyde are added, the whole well stirred, and allowed to stand for twenty-four hours. The action of the formaldehyde appears to be twofold. In the first instance, it effectually prevents any tendency of the albumen to coagulate in the hot solution, and thereby to cause mischief. But, as comparative experiments showed beyond any doubt, it also has a most distinct effect upon the india-rubber, which collects on the top of the wash-water in the form of a snow-white cake of rubber of such strength and toughness that it can in one mass be lifted out from the barrel. On cutting this cake open, it will be found that it is rather spongy, being full of little holes which are still filled with some of the albuminous though very dilute mother liquor. If, therefore, the rubber were dried in this state it is obvious that it would still contain a small quantity of the objectionable albuminous matter. For this reason the rubber contained should at once be taken, cut into strips, and subjected to a thorough washing upon an ordinary rubber washing machine."

I made several attempts, when in the Gold Coast, to separate rubber from Para latex in the manner above suggested, but failed in each instance, although the latex stood, in one or two instances, for nearly three weeks without the rubber separating out.

The following method was suggested by the same author, and he states* that it produces similar results to that previously mentioned :-

"To every gallon of the rubber latex, from $\frac{1}{2} \mathrm{Oz}$. to I oz. of formaldehyde (formalin 40 per cent. solution) is added, the latex well stirred and allowed to stand for one hour. Then to each gallon of latex a solution of $\mathrm{I} \mathrm{lb}$. of sodium sulphate (commercial) in one pint of boiling water is added while still hot, and the mixture stirred for some time. Coagulation may take place immediately or after several hours' standing, according to the condition (age) of the latex. Great care must be taken to use a sodium sulphate of entirely neutral (not acid) reaction.

"Rubber prepared in this manner will be found free from every trace of albuminous matter. It is of a degree of purity greatly surpassing the finest Para rubber ever produced, and 
therefore contains a percentage of pure rubber exceeding that of every known rubber quality.

"Its only impurity consists of about 2 per cent. of a viscous resinous matter, the removal of which is scarcely worth while."

The smoking method employed by the rubber collectors in Brazil produces an article which, although sometimes contaminated with dirt, is practically free from putrefaction and mould, as creosote and carbon in the smoke act as antiseptics, and prevent their developing.

Alum is largely used as a coagulant, but its use is objectionable, as rubber prepared by it perishes, owing to the action of the alum upon the rubber forming a resinate of alumina. Manufacturers state that rubber coagulated by it when placed on the market often contains as much as 6 per cent. of alum.

Common salt is also largely used, and although it possesses antiseptic properties its use should be condemned, as it tends to leave a large quantity of moisture in the rubber.

The employment of chemicals for the coagulation of rubber is apt to seriously injure the product, and therefore cannot be recommended, notwithstanding the fact that Para rubber exported from Ceylon and the Straits Settlements has realised excellent prices ever since it was first placed on the market, and, in fact, nearly always in advance of the finest rubber from Para.

Prepared in the manner described, it must contain the constituents which support mould and fermentation, or, in other words, it lacks what is probably the most important character to which the Brazilian product owes its reputation. This character, as we have previously pointed out, is imparted to the product by the smoking process employed in preparing the rubber.

This process is, however, much more tedious than the Ceylon one, as will be seen on comparing the two. The Brazilian collector takes a paddle, dips it in the latex, and holds it over the smoke of a fire fed with wood and palm nuts, or if the latter are not obtainable, with the former alone, until the rubber coagulates and dries. This performance is repeated again and again until the rubber has grown to the required size.

By the Ceylon method all that is necessary is to pour the latex into saucers, press out the moisture when it has coagulated, and lay the coagulum out to dry. 
It will therefore be quite evident that to obtain a cultivated product possessing the valuable characters of the Brazilian and the cultivated rubber, and at the same time free from the objections mentioned above, it will be necessary to find a method for preparing the cultivated product which will supply these conditions. This is apparently only possible by antisepticising it.

Creosote is produced by the destructive distillation of wood, so that if the cultivated article were rolled out into thin sheets, well washed, thoroughly pressed, and exposed to the smoke of a wood fire, it should be antisepticised sufficiently for all practical purposes.

Suggested Method For Preparing Rubber Biscuits oN SMall Estates.

Immediately the latex has ceased flowing into the collecting cups, it should be collected and conveyed to the curing-house, in order to prevent its coagulating in the cups. An ordinary milk pail will be found a useful article for this purpose.

It now requires straining to free it from any bark, leaves, dirt, \&c., with which it may have become contaminated. Fine copper or brass wire gauze or muslin will be found suitable for this operation. But perhaps the most satisfactory article to use is a fine hair seed-sieve.

An equal quantity of water added to the latex will facilitate the work. But the material employed for straining must not be rubbed with the hand to assist the passage of the fluid, as this is sufficient to coagulate some of the latex and thus choke up the holes. As soon as the latex has been strained, it should be poured into vessels which will permit of as much of the latex as possible being exposed to the atmosphere. The vessels generally employed on rubber plantations in the East are composed of enamelled iron, round-dish shaped, with a diameter of I foot, and about $1 \frac{1}{2}$ inch deep. The employment of these is, however, open to the same objection as that put forward with regard to using tin-plated collecting cups. In course of time the enamel gets chipped off, leaving the iron bare to the oxidising action of the atmosphere, and particles of oxide of iron get into the latex. 
Consequently vulcanite vessels would probably prove more satisfactory.

It is important that the curing-house be kept clean. It should not be situated near any works which create dust; in fact it is necessary to treat a rubber curing-house in an exactly similar manner with regard to cleanliness as a dairy.

Within twenty-four hours the rubber particles will have coagulated, and risen to the surface in the form of a thick curd. Immediately this occurs the coagulum should be lifted out, thoroughly washed, and then pressed between heavy rollers to force out any liquid which may have been imprisoned inside the mass. To effect this a machine similar to a laundry mangle is recommended. This process needs very careful attention, as the stench common to many rubbers is due to putrescent moisture shut up in this way, and it naturally has in time a deteriorating effect upon the product. After pressing, the rubber discs should be placed on a clean porous surface to drain, and then placed in the smoke of a wood fire for at least a day. Afterwards they should be spread singly on shelves made of canvas, rattan, or some similar material which will permit a free passage of air through.

The shelves of a tea-withering house answer admirably; the illustration (Fig. I7) depicts one employed for this purpose in Ceylon. Artificial heat is not absolutely essential, but hastens the drying process.

On no account must the rubber be exposed to the sun, as this produces a permanent stickiness, which considerably depreciates its value.

Drying should be continued until all opaque blotches, which are due to moisture, have vanished, and the rubber is translucent and of a uniform colour all over.

The weight of dry rubber obtained from a given quantity of latex is approximately in the proportion $\mathrm{I}$ to 2, i.e., I lb. of latex will yield about $\frac{1}{2} \mathrm{lb}$. of dry rubber.

All tapping instruments, collecting cups, coagulating pans, $\& c$. , should be thoroughly washed after use and kept clean.

A chemical analysis of Para rubber prepared in this manner from ten-year-old trees growing in the Botanic Gardens, Gold Coast, gave the following results :- 
Moisture

Ash

Resinous matter

Caoutchouc

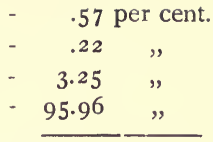

I00.00 per cent.

Samples of this rubber were submitted by the Director of the Royal Gardens, Kew, to Messrs Hecht, Levis, \& Kahn, rubber brokers, 36 Fenchurch Street, E.C., who reported that the rubber was of excellent quality, well cured, free from impurities, and valued it at $4 \mathrm{~s}$. 6d. to $4 \mathrm{~s}$. $7 \mathrm{~d}$. per $1 \mathrm{~b}$. Sheet may be similarly prepared by pouring latex into shallow oblong vessels. Buyers prefer sheets about 2 by I foot long, and about $\frac{1}{8}$ inch thick. Biscuits should be about the same thickness, with a diameter of 8 or Io inches.

With the constantly increasing number of trees coming into bearing, it has been found necessary on large rubber estates to adopt new methods of rubber production which admit of more expeditious treatment of the latex.

\section{A Centrifugal Strainer.}

With a view to improve upon the somewhat tedious method of separating mechanical impurities from the freshly collected latex by passing it through sieves, \&c., an apparatus known as the Macadam centrifugal machine has been manufactured. The latex is poured into a cloth bag contained in a receptacle which may be made to revolve up to 10,000 revolutions per minute, but 3,000 revolutions per minute is usually found sufficient to complete the operation.

\section{Coagulating Machines.}

The coagulation of the latex may be considerably expedited by employing the Michie-Golledge machine (Fig. I 8) which has been specially manufactured for this purpose. It should be specially noted that the addition of acid to Hevea latex is necessary before coagulation is effected. The following description of this machine has been extracted from Messrs Walkers' catalogue :-

"The Michie-Golledge rubber coagulating machine consists 
of a revolving cylinder A (Fig. 19) with ribs $\mathrm{B}$ on its inside, and. curved blades $\mathrm{C}$, which are fixtures as shown. The rubber latex is poured into the cylinder $\mathrm{A}$, which is then set in motion. The revolving cylinder and its ribs $\mathrm{B}$ force the latex forward on to the blades $\mathrm{C}$, which carry it into the centre, creating a kind of vortex or whirlpool in the space $\mathrm{D}$, where the rubber forms into a sponge-like ball.

"The latex should be diluted with clean water in the proportion of one part of latex to four parts of water approximately. The mixing can be done either in the field by putting water into the collecting cups, or in the curing-house. The latex when

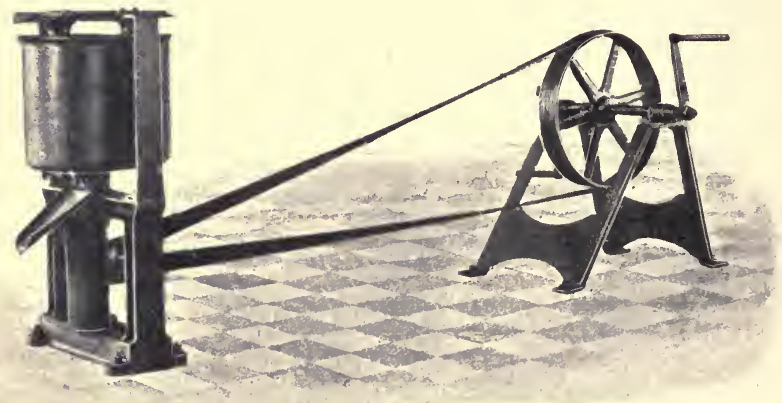

FIG. 18.-" Michie-Golledge" Rubber Coagulating Machine.

brought in should be well strained; this can be done through ordinary 'grey cloth' or through very fine mesh brass weaving (No. 40). The latex should then be poured into the machine. If it is allowed to stand for a minute or so after straining, any sand which the strainer has not removed will sink to the bottom of the vessel, and may be retained there when the liquid is poured off. Eight to ten gallons of the latex (liquid) may be considered a charge. The machine should be set in motion after the charge of latex has been poured into the pan, and acetic acid in the proportion of one dram glacial acetic acid to one gallon of latex should then be added. The glacial acetic acid is more convenient in a diluted form of, say, one part of acid to two 
parts of water. Three drams of this mixture will be used per gallon of latex. During the first two or three minutes of working, the machine should be driven at a speed of about I 80 revolutions per minute (30 revolutions of driving handles). At the end of this time the sound from the cylinder will have become deadened and the latex in the centre will have taken a creamy appearance. The speed should then be reduced to about 120 revolutions (20 revolutions of handles), and a little later to I00 ( 16 or I7 revolutions of handles). The coagulated rubber should

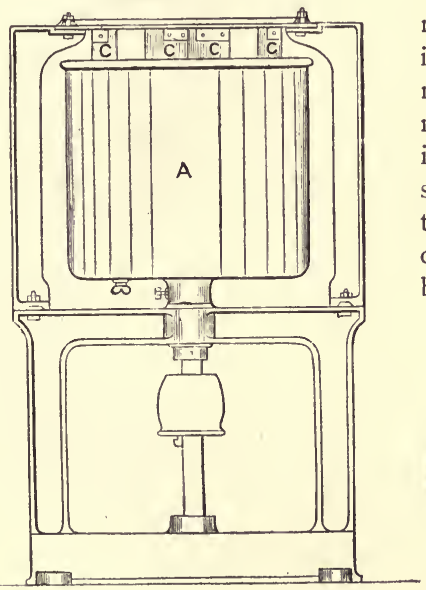
begin to form into a spongy mass between the blades and in the centre of the pan in four minutes from the time the machine starts working, and in five minutes the process should be complete. To prove that separation of rubber is complete, put a stick down behind one of the blades and

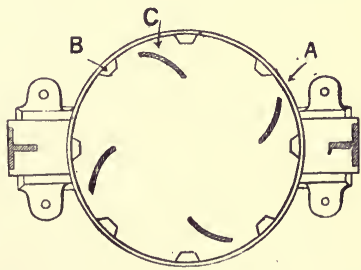

FIG. 19.-Sectional Diagram of the "Michie-Golledge" Rubber Coagulating Machine.

run the water adhering to it on to some convenient spot on the top of the machine, when it will be seen that the water is quite clear and free of rubber globules.

"In case separation is not perfect it will probably be found that in the finishing off, the machine has been run too fast. - A minute or two longer at slower speed will put this right. The mass of coagulated rubber should be at once removed and rolled out into sheets before it hardens.

"Rolling.-If a 'Dolly' mangle is used, lumps pulled off the 
mass by hand should first be put through without any weight. A little weight should be applied the second time through, and additional weight the third time, which will probably complete the process. A little practice will determine the exact amount of rolling necessary. Care should be taken not to roll too much, as excessive rolling, or squeezing, by closing the pores, retards the drying.

" Worm Rubber.-To make 'worm' rubber, cut the sheets into

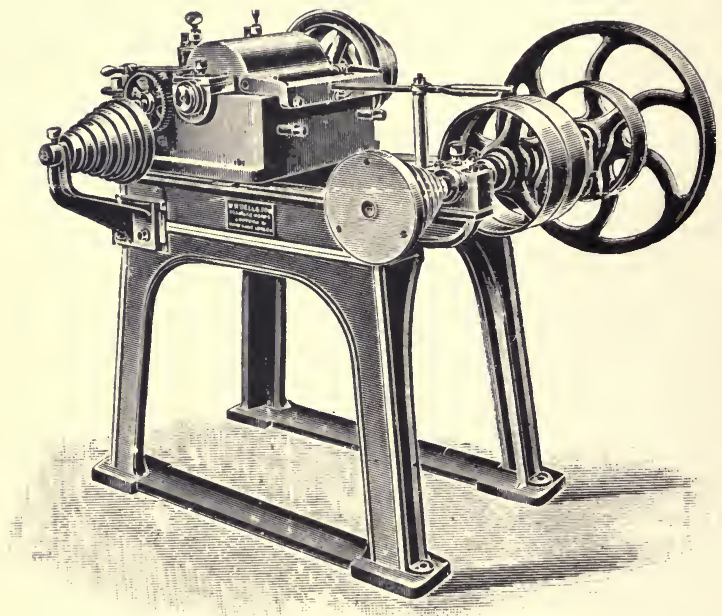

FIG. 20.-Messrs Walker's "Worm" Rubber Cutting Machine, used in the Michie-Golledge Curing Process.

very thin strips, about $I_{2}^{\frac{1}{2}}$ inch to 2 inches long and $\frac{1}{8}$ inch in width."

Messrs Walker \& Co. have recently placed on the market a "worm" rubber cutting machine (Fig. 20), by the aid of which they claim that $120 \mathrm{lbs}$. of dry rubber can be cut up per hour.

"Drying.-Put the rubber where a fan can draw dry air (heated air of high temperature should not be used) through it. In about twenty-four hours the rubber will be dry, and may then be heaped 
until time of packing. If a fan is not available it is sufficient to spread in a dry place.

"Crêpe Flake and Lace Rubber.-When making rubber in

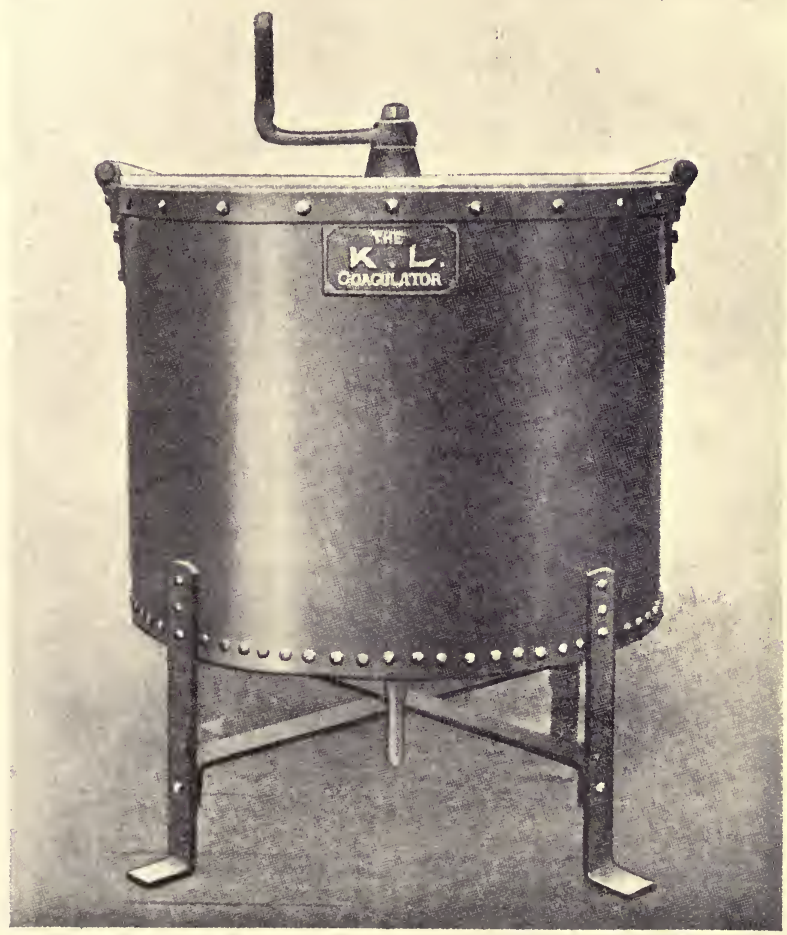

FIG. 21.-The "K.L." Coagulator.

either of these forms, pass the freshly coagulated mass directly to the rolling or washing machines."

The "Hodvey" coagulator, invented by Mr F. G. Harvey of Pataling Estate, Selangor, is now placed on the market by the 
Federated Engineering Company, Ltd., Kuala Lumpur, Selangor, under the name of the "K.L." Coagulator shown in Fig. 2 I.

The subjoined instructions are given for manipulating it :-

"The following solution of acetic acid has been found to give good results for coagulation :-

6 of water to $\mathrm{I}$ of glacial acetic, and

$\mathrm{I}_{4}^{3}$ fluid oz. of the solution to every 4 gallons of latex.

"Having strained the latex into the coagulator, turn the handle slowly while pouring in the solution; the latter should be poured in slowly, so as to be as widely diffused as possible throughout the latex.

"The solution having all been poured in, continue to turn for about five minutes; a medium pace should be maintained, and the handle occasionally reversed for a turn or two.

"Supposing there to be about 35 gallons of latex in the coagulator, it will be noticed that coagulation starts in about five minutes, and when once this is the case, it will be found best to let it stand, and then turn again in alternate spells of short duration. Quantities of 30 to 50 gallons of latex may be coagulated in about six or seven minutes."

The inventor asserts that "by the use of this machine all decomposition of the proteids contained in the latex is rendered impossible, and when the coagulated rubber is washed through a machine, there is an entire absence of that unpleasant odour so associated with new rubber which has been coagulated in pans."

\section{Crêpe ANd Washed RubBer.}

The manufacture of crêpe rubber, briefly described, consists in passing the freshly coagulated rubber through a washing machine; although scrap rubber may also be turned into this form.

Planters have adopted a method somewhat similar to one of the processes employed by manufacturers in treating wild rubber. The principal advantages claimed for it are, that it dispenses with a large amount of the labour involved in the preparation of biscuit rubber; the latex may be coagulated in bulk, and the coagulum cut up into lumps and passed direct into the machine. Mechanical impurities and some of the substances which encourage putrefaction are expelled. The rubber is turned out in sheets with an irregular surface, thereby effecting a saving 
of storage room and facilitating drying. Burgess describes a washing machine suitable for plantation use as follows :-

"This machine consists essentially of two steel rollers which revolve on horizontal axes parallel to one another; the distance between the surface of the two rollers can be adjusted and varies from $\frac{3}{4}$ inch to practical contact. The rollers revolve at different speeds and are driven by power transmitted by belt and pulley through gear wheels to the rollers themselves. The axes of the two rollers may be on the same horizontal plane, more usually one is slightly above the other. A stream of water flows over the surface of the rollers all the time they are in use. When the machine is used, freshly coagulated lumps of rubber are put in between the rollers, which are separated about $\frac{1}{4}$ inch. The rubber is passed through several times, the rollers being gradually approximated to each other, and the rubber becomes compacted, and to some degree hardened. At the same time, the effect of the differential rate of movement of the two roller surfaces is to subject the rubber to a shearing stress, which stretches and tears it to pieces, and it is here that the peculiar property of rubber is clearly seen. The elastic stretching and rebound kick out any gross mechanical impurity that may be present, and when the machine is used on scrap rubber, there is a perfect shower of dirt, pieces of bark, and wood thrown out from the front of the machine. Freshly cut or torn surfaces of the rubber re-unite and emerge as a continuous sheet. At the same time the stream of water thoroughly washes out any impurity soluble in water that may be left in the rubber. The final product is a coherent but granular sheet of rubber, the thickness of which can be regulated by the distance left between the rollers."

Washed rubber was not well received when first placed on the market, as manufacturers stated they preferred to perform the washing themselves, but that there is now a good demand for this form of rubber is demonstrated by the sale reports. It is not so liable to arrive on the market in a heated or tacky condition as unwashed rubber, which is certainly an important point in its favour, but whether the removal of a portion of the socalled organic impurities does not affect the resiliency of the product is still an open question. Very thin sheets are not well received by buyers, and it is considered that a thickness of about $\frac{1}{6}$ inch should be aimed at. 


\section{WORM RUBBER.}

Worm rubber merely consists of sheet rubber cut up into shreds to facilitate drying and packing.

\section{LACE RUBBER.}

The method of preparing lace rubber is somewhat similar to that employed in the manufacture of crêpe rubber. It is very thin in texture and far more porous than crêpe, and consequently dries more rapidly.

\section{Flake Rubber.}

The freshly coagulated rubber is passed through a rolling machine with horizontally arranged corrugations in the rollers which cause the rubber to be turned out in thin flakes. None of the three last mentioned methods are largely employed. The principal advantages of each is that the rubber is rapidly dried and easily packed. Each form has been well received by buyers.

\section{BLOCK RuBber.}

The manufacture of cultivated Para rubber in block form is of more recent date than that of any of those previously described, having only commenced in the year 1906.

As the crêpe rubber is taken from the washing machine it is placed in a vacuum drying apparatus for about two or three hours or until nearly dry, for if left in the vacuum drier after all the moisture has been extracted it is liable to become tacky. When taken from the vacuum drier rubber is in a pliable condition, and if submitted to pressure readily forms into a homogeneous mass. This is effected by placing it in a block press. A description of a recently invented press specially adapted for use in connection with plantation rubber, extracted from the British Trade Journal, Ist Sept. 1907, is as follows :-

"Now that 'block' rubber is again coming into vogue, it will be of interest to notice the latest form of rubber press, as here illustrated (Fig. 22). The success of 'block' rubber at the recent exhibition of rubber at Ceylon, to which we have already referred in these pages, has given a stimulus to that form, and now that it can be adopted on properly organised plantations, and is not likely to come into bad repute again by reason of 
adulteration, there is no doubt that its use will become more and more general, especially as it enables rubber to be secured and shipped in a day or two.

"Our illustration shows one of a number of mechanical block rubber presses, which have recently been supplied to Messrs The Mabira Rubber Company, Uganda, to the instructions of Dr Christy, the makers being Messrs David Bridge \& Co., of Castleton, Manchester. A description of this press will not be out of place, as it differs from any that have been previously made. It consists of a powerful screw fitted with a machine-cut worm wheel, driven by a steel-cut worm by fast and loose pulleys. A reversing motion is arranged for the quick withdrawal of the platten. This is carried on two strong steel columns, bolted to the base. The platten proper has a detachable platten cottered to it, on which are letters for branding the block rubber. The box is detachable, therefore any number of boxes can be used with the one press. Each box is fitted with

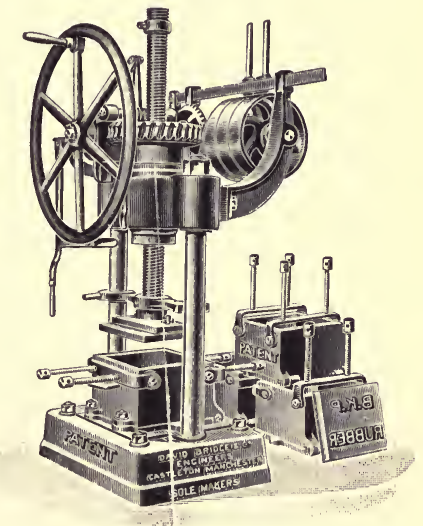

FIG. 22.- Messrs David Bridge \& Co.'s Block Rubber Press. two strong wrought-iron bridles, with four powerful screws. After the crêpe rubber has left the vacuum drier, it is pressed in the box, and when under pressure the bridles are brought over to an upright position. The screws are then brought down on the top of the false platten, the cotters of which are knocked out, leaving the rubber under pressure, and the screws run back clear of the box; the latter is then removed and run on to the lower shelf of the vacuum drier for a period of setting. When quite set, it is again removed from the vacuum drier. The bottom of the box, which is hinged, then allows the block to be forced out by the four vertical screws. 
"This press is also fitted with a hand motion, which is quite satisfactory in the absence of mechanical power. The power required to drive by belt is from 2 to 3 horse power. The size of the boxes varies. A convenient size is I I inches by 9 inches, and the thickness of the block is about $4 \frac{1}{2}$ inches. The total weight of this press is about 17 cwt., with one box, and it can be

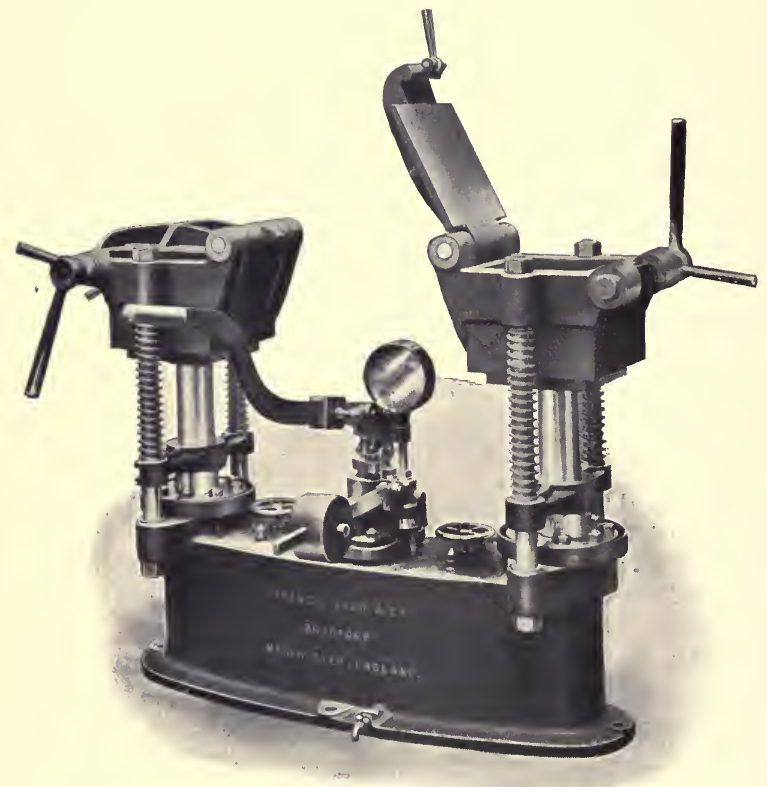

F1G. 23.-Messrs Francis Shaw \& Co.'s Hydraulic Blocking Press.

dismantled so easily that there is no difficulty in transporting the various parts to their destinations. The press can also make a block of any thickness from I inch to 6 inches, depending upon the first packing of the crêpe in the box."

Underneath the foot of the plunger is arranged a detachable name plate, which is held in position on the pressed rubber by the two hinged saddles and four screws. 
An improved type of a hydraulic block press, specially designed and manufactured by Messrs Francis Shaw \& Co., for compressing rubber into blocks for shipment, is shown, Fig. 23.

This is a twin press having two boxes worked from a single pump, the power for working and the presses being entirely selfcontained. The pump is fitted on the stand, which forms a tank containing the water, by means of which the presses are worked. The total pressure obtained is about 12 to 15 tons on each ram.

In addition to expediting the work of the estate a minimum surface of the rubber is exposed to deleterious atmospheric influences, and where freight is charged on cubical capacity an appreciable economy is effected.

\section{SCRAP Rubber.}

The latex which flows over on the bark from the tapping channels, and that which exudes from the incisions, but fails to reach the collecting vessels, usually coagulates in a few hours, and is picked off by hand. That which adheres to the collecting cups, pails, \&c., should also be collected. This forms what is known as scrap rubber. After being thoroughly washed, and mechanical impurities separated, it may be placed on the market in this condition, or be passed through the washing machine immediately after collection, and turned into crêpe rubber.

The parings of bark from the tapping incisions should be likewise collected and passed through the same machine which macerates the bark and extracts the particles of rubber therein. This process is considerably facilitated by soaking the bark parings in water for several days previous to passing them through the machine, and by the use of caustic chemicals. These forms of rubber are improved by being smoked over a wood fire. 
Results of Analyses* of Various forms of Para Rubrer frod the Federated Malay States.

\begin{tabular}{|c|c|c|c|c|c|c|c|}
\hline 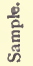 & Description. & Weight. & $\begin{array}{l}\text { Mois- } \\
\text { ture. }\end{array}$ & Ash. & Resin. & $\begin{array}{l}\text { Pro- } \\
\text { teids. }\end{array}$ & $\begin{array}{l}\text { Caout- } \\
\text { chouc. }\end{array}$ \\
\hline & & Grams. & Percent. & Percent. & Percent. & Percent. & Per cent. \\
\hline I & Crêpe, pale yellow - & 245 & 0.22 & 0.16 & 2.75 & 2.27 & 94.60 \\
\hline 2 & Large thin biscuits, pale & 225 & $0.3^{6}$ & 0.29 & 2.23 & $2 \cdot 3 I$ & 94.8 I \\
\hline 3 & Thin sheets, pale, opaque & 255 & 0.54 & 0.48 & I. 64 & 2.66 & 94.68 \\
\hline 4 & Crêpe, almost white & I 80 & 0.26 & $\circ 34$ & $3 \cdot 5^{8}$ & 3. I 8 & 92.64 \\
\hline 5 & Crêpe, dark brown & 235 & 0.60 & 0.56 & 2.89 & 2.50 & 93.45 \\
\hline 6 & Sheet, very pale - & 230 & $0.3^{8}$ & 0.36 & 1.78 & 3.08 & 94.40 \\
\hline 7 & Crêpe, almost white & 260 & $0.3^{2}$ & 0.18 & 2.83 & 2.99 & 93.68 \\
\hline 8 & Large biscuit, pale & 250 & 0.42 & 0.46 & $1.3^{8}$ & 2.13 & $95.6 \mathrm{I}$ \\
\hline 9 & Crêpe, light brown - & 240 & 0.28 & 0.23 & 2.82 & 2.19 & $94 \cdot 4^{8}$ \\
\hline IO & Corrugated sheet, rather & & & & & & \\
\hline & dark $\quad-\quad-$ & 280 & 0.44 & 0.35 & 2.45 & I. 94 & 94.82 \\
\hline I I & Corrugated sheet, pale - & 280 & $0.3^{8}$ & 0.28 & 1.83 & $2 \cdot 3^{6}$ & 95.15 \\
\hline I 2 & Corrugated sheet, rather & & & & & & 87 \\
\hline & dark - - - & 280 & $0.3^{0}$ & 0.34 & 2.07 & $2 \cdot 36$ & 94.87 \\
\hline I 3 & Corrugated sheet, pale - & 320 & $0.5^{2}$ & 0.43 & 2.57 & 3.06 & $93 \cdot 4^{2}$ \\
\hline I 4 & Crêpe, yellow - - & 300 & 0.42 & O. I 4 & 3.01 & 2.90 & $93 \cdot 53$ \\
\hline 15 & Thin sheet, pale - & 280 & 0.22 & $0.2 \mathrm{I}$ & I. 87 & $\mathbf{1} \cdot 35$ & 96.35 \\
\hline 16 & Sheet, pale - & 340 & $0.3^{8}$ & 0.27 & 1.75 & 2.13 & 95.47 \\
\hline & Minimum values - & & 0.22 & O. I 4 & I.38 & I. 35 & 92.64 \\
\hline & Maximum values & $\cdots$ & 0.60 & $0.5^{6}$ & $3.5^{8}$ & 3.18 & 96.35 \\
\hline
\end{tabular}

* Imperial Institute Bulletin, vol. v., No. 3, p. 247.

Kelway Bamber's Analysis of Various Samples of Cultivated Para Rubber which were awarded Gold Medals at the Ceylon Rubber Exhibition.

\begin{tabular}{|c|c|c|c|c|c|c|}
\hline & & Moisture. & Resin. & Proteids. & Ash. & Caoutchouc. \\
\hline Para biscuits - & & Per cent. & Per cent. & Per cent. & Per cent. & Per cent. \\
\hline Arapolakanda & - & 0.28 & I. 84 & 2.12 & 0.20 & 95.56 \\
\hline $\begin{array}{l}\text { Duckwari- } \\
\text { Para sheet- }\end{array}$ & - & 0.68 & $2 \cdot 3^{2}$ & 3.00 & $0.3^{6}$ & 93.64 \\
\hline $\begin{array}{l}\text { Syston - } \\
\text { Para crêpe- }\end{array}$ & - & 0.30 & 2.74 & 2.25 & 0.20 & $94 \cdot 5^{I}$ \\
\hline $\begin{array}{l}\text { Culloden - } \\
\text { Para block- }\end{array}$ & - & 0.36 & 2.04 & 2.25 & 0.22 & 95.13 \\
\hline Lanadron & - & $0.3^{6}$ & 2.44 & $3 \cdot 3 I$ & 0.20 & 93.69 \\
\hline
\end{tabular}




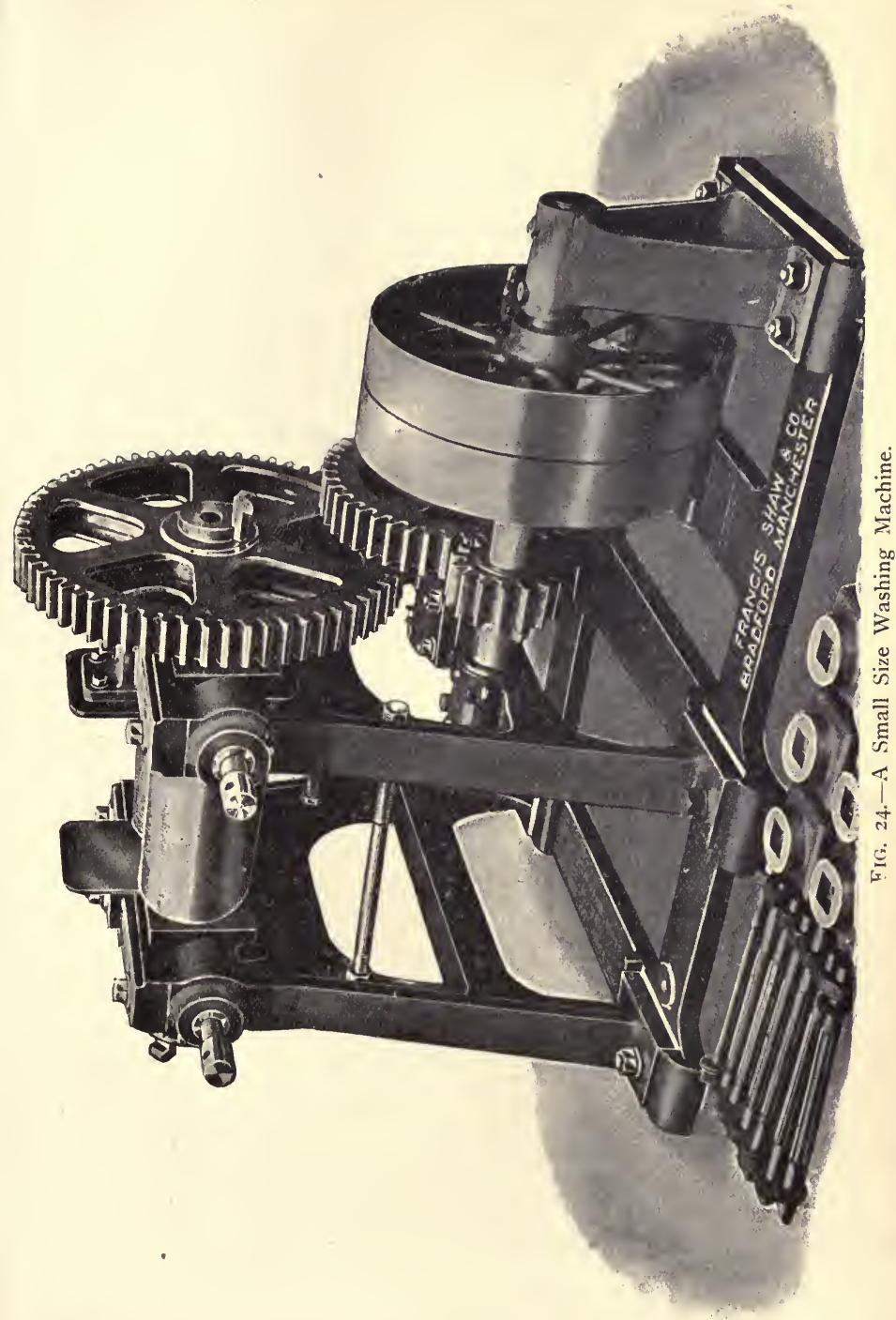




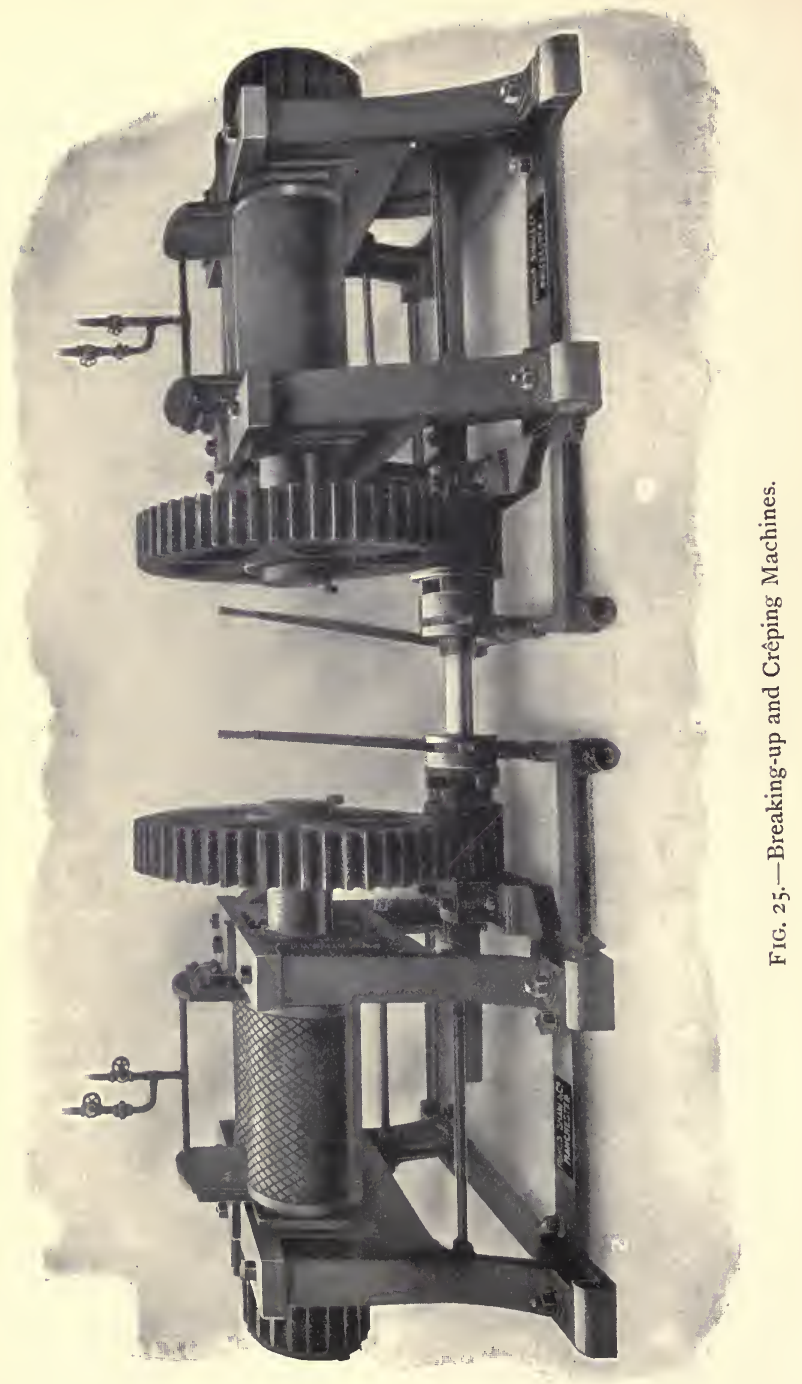




\section{WASHing MaCHINES.}

The washing machine, Fig. 24, the rollers of which measure 9: in. diameter and 18 in. long, is the smallest size recommended by Messrs Francis Shaw \& Co. for commercial use. It is supplied with fast and loose pulleys for driving, and the machine and gearing are carried on a strong cast-iron base plate which facilitates erection, and maintains the driving parts in perfect alignment.

The net weight of this machine is $30 \mathrm{cwt}$. and the shipping weight $32 \frac{1}{2} \mathrm{cwt}$. It requires approximately 7 B.H.P. to drive it, and turns out about 800 lbs. of rubber per day of ten hours.

Fig. 25 shows a large size pair of breaking-up and crêping machines by the same makers. The rollers of these measure I 2 in. diameter and are 18 in. long. The main line shaft is about 6 in. above the floor level, and carried on the base plates of the machines, but can be placed under the floor if required.

\section{The Rubber FACtory.}

On the various rubber estates, where large numbers of trees will shortly be coming into bearing, planters should have everything in the way of appliances ready to deal with the latex.

The rubber factory requires special consideration, for unless this be properly equipped it will be impossible to expeditiously treat and despatch the rubber in large quantities. We are indebted to Messrs Francis Shaw for plans of two different factories.

Fig. 26 is that of a factory for washing, drying, and blocking rubber. The machinery in this consists of a pair of breaking and washing machines which are driven by a semi-portable steam engine, this latter also supplying steam for the drying stove. Provision for three hydraulic presses is also made.

Fig. 27 illustrates a factory where the machinery for washing, drying, and blocking rubber is driven electrically. There are two breaking and four washing machines, which are capable of an output of 2 tons of either block or crêpe rubber per day. The machinery is driven by a 75 B.H.P. motor through a worm 


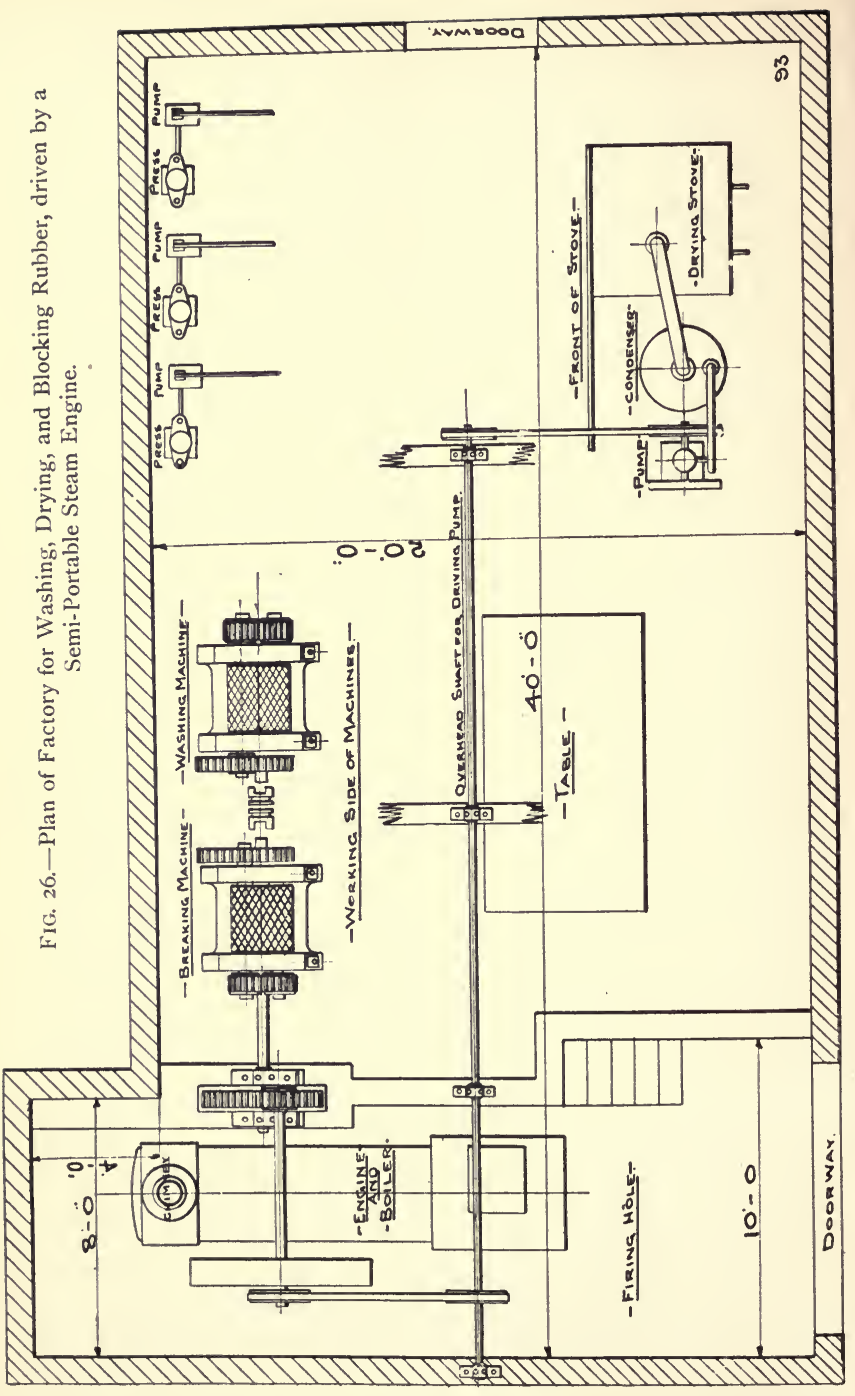




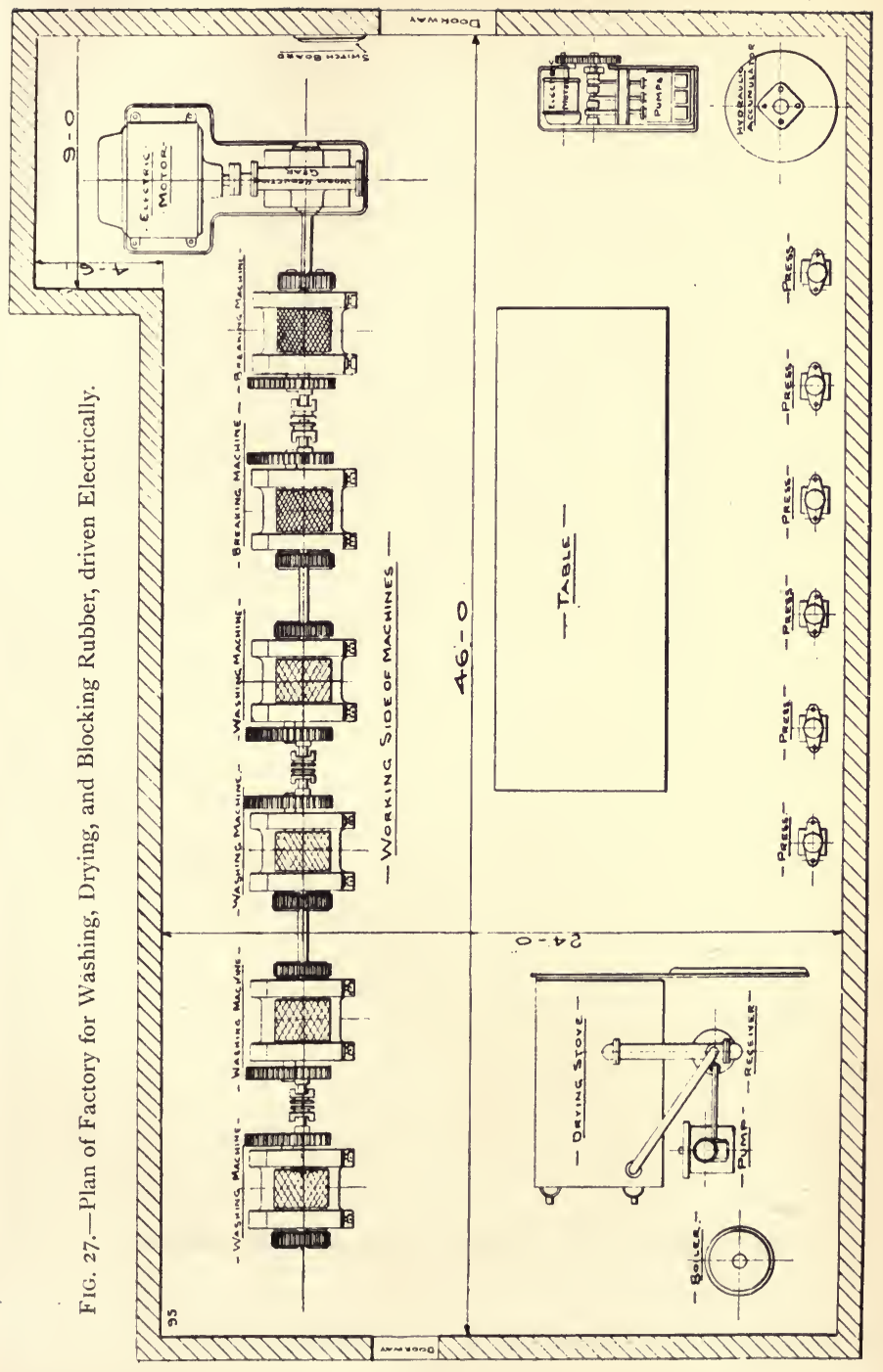




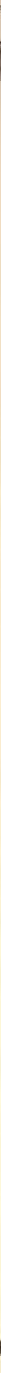

FIG. 28. 
reduction gear. The drying store is provided with a small boiler, and the hydraulic blocking presses are supplied with electrically driven pumps and accumulator.

A plan of the apparatus required for Dr Olsson-Seffer's patent system of treating Castilloa rubber latex is given in Fig. 28. Although this was specially constructed for dealing with Castilloa rubber latex, the makers state that it can be modified to deal with that of Hevea brasiliensis. 


\section{CHAPTER XI.}

\section{THE ANTISEPTICISATION OF RUBBER.}

\section{Defects of Plantation Rubber.}

MANUfACtuRers complain that much of the plantation Para rubber at present received on the market is lacking in "nerve," it works soft between the masticating rollers, and its keeping qualities are far inferior to the Brazilian product. The latter has been known to keep in good condition for sixty years, whereas many samples of plantation rubber have lost their tensile strength in as many weeks. Various reasons have been suggested as the possible cause of these important differences in the two products, such as (I) the altered conditions under which the cultivated trees grow ; (2) the tapping of too young trees; (3) the tapping of immature renewed bark; and (4) the mode of preparing the rubber.

No great importance attaches to the first suggestion in view of the healthy, robust growth of cultivated trees. Analyses made of the latex from cultivated and wild trees show no striking difference in the chemical composition. So far as cultivated Para rubber is concerned, however, it would appear that the chemical composition of weak and strong rubber, as also rubber obtained from young trees and old trees, is very similar.

Nevertheless suggestions (2) and (3) certainly merit far more serious consideration, for it is well known that weaker rubber is produced by young trees than by old ones growing under similar conditions, and it has already been shown that the latex obtained from immature renewed bark is poorer in its caoutchouc content than that produced by the original bark.

It is considered highly probable that in the method of preparation will be found the principal cause of the inferiority of plantation Para rubber as compared with wild Para, so far as the keeping properties of the raw product are concerned. 


\section{Creosoting the Latex.}

It is considered that the valuable physical properties of South American Para rubber are largely due to the antisepticising method employed in coagulating the latex. The collector takes a paddle or some similar article, dips it in the freshly collected latex, and holds it in the smoke of a fire fed with wood and palm nuts.

The smoke given off by the palm nuts is reputed to contain creosote and acetic acid, the former antisepticising the putrescible nitrogenous substances in the latex, while the latter causes coagulation. As the paddle is alternately dipped in the latex and held in the smoke, it will be seen that the resulting product consists of thin antisepticised films of rubber closely packed one upon the other. A minimum surface is exposed to light and atmospheric influences. The outside of each block or cake is blackened, but the interior remains a pale grey colour until the block is cut up, and it is exposed to oxidising influences.

The bulk of cultivated Para latex is either allowed to coagulate naturally or this process is effected by the addition of chemical reagents.

Natural coagulation occurs through the action of the proteid or albuminous matter which becomes insoluble or, as is more generally stated, coagulates. In the coagulum are included the caoutchouc globules and various other matters in the latex. Whilst the putrescible substances are present in the rubber, fermentation and putrefaction is always liable to occur providing moisture be present. However well the rubber may be dried during preparation, it is obviously impossible to protect it from the moisture present in the atmosphere, unless it be kept in specially prepared chambers. Too rapid drying encourages "tackiness." But this form of "tackiness" is fundamentally different from that caused by the action of bacteria on the albuminous matters in the latex, which does not occur in rubber from which they have been eliminated.

The commonest reagent employed to coagulate Para latex is acetic acid. The amount of acid required to bring about coagulation is usually about two or three drops to a gallon of diluted latex. The exact amount required must obviously 
depend upon the percentage of albuminous matter present in the latex to be acted upon. Whilst the latex is in an alkaline condition the albumen remains soluble, but it is only necessary to neutralise or slightly acidify the latex to render it insoluble. The exact amount of acid to apply may be ascertained by testing with litmus paper. When the latex is in a neutral condition litmus paper will neither be turned red nor blue; immediately acidity is formed the latter will turn red. It is important to bear in mind, however, that in the addition of too much acid there is a danger of re-dissolving the proteids, thus retarding coagulation. Here again the putrescible matters remain in the rubber.

It has been shown that in the manufacture of crêpe rubber a certain amount of them are washed away, but no mechanical means exist for the extraction of the whole from coagulated rubber.

The use of centrifugal machines has been suggested for separating the caoutchouc globules free from proteids, resins, \&c., in a similar way to that employed for treating animal milk, but Wright states: "It is very difficult to separate the caoutchouc by centrifugal force, and on several occasions a speed of 10,000 revolutions per minute did not effect a separation of the caoutchouc of normal latex."

The proteids may be kept quiescent in Para latex by adding some antiseptic substance, such as creosote, or corrosive sublimate, i.e., bichloride of mercury.

Creosote does not mix readily with latex, but if first diluted with alcohol in the proportion of ten parts alcohol to one of creosote the process is simplified. Biscuits prepared by Parkin from Hevea latex with creosote and acetic acid had not lost any of their tensile strength nor appeared to have deteriorated in any way eight years later.

It was suggested at the Ceylon Rubber Exhibition that, as Brazilian Para rubber contained about 15 per cent. of moisture as against the I per cent. of moisture usually present in cultivated Para rubber, the latex of the latter might be treated with creosote and the rubber blocked, leaving a large percentage of moisture, thereby saving the time and labour spent in drying rubber. Rubber so prepared has not met with much favour, some buyers refusing to purchase the wet block although quite agreeable to accept that in a dried state. 


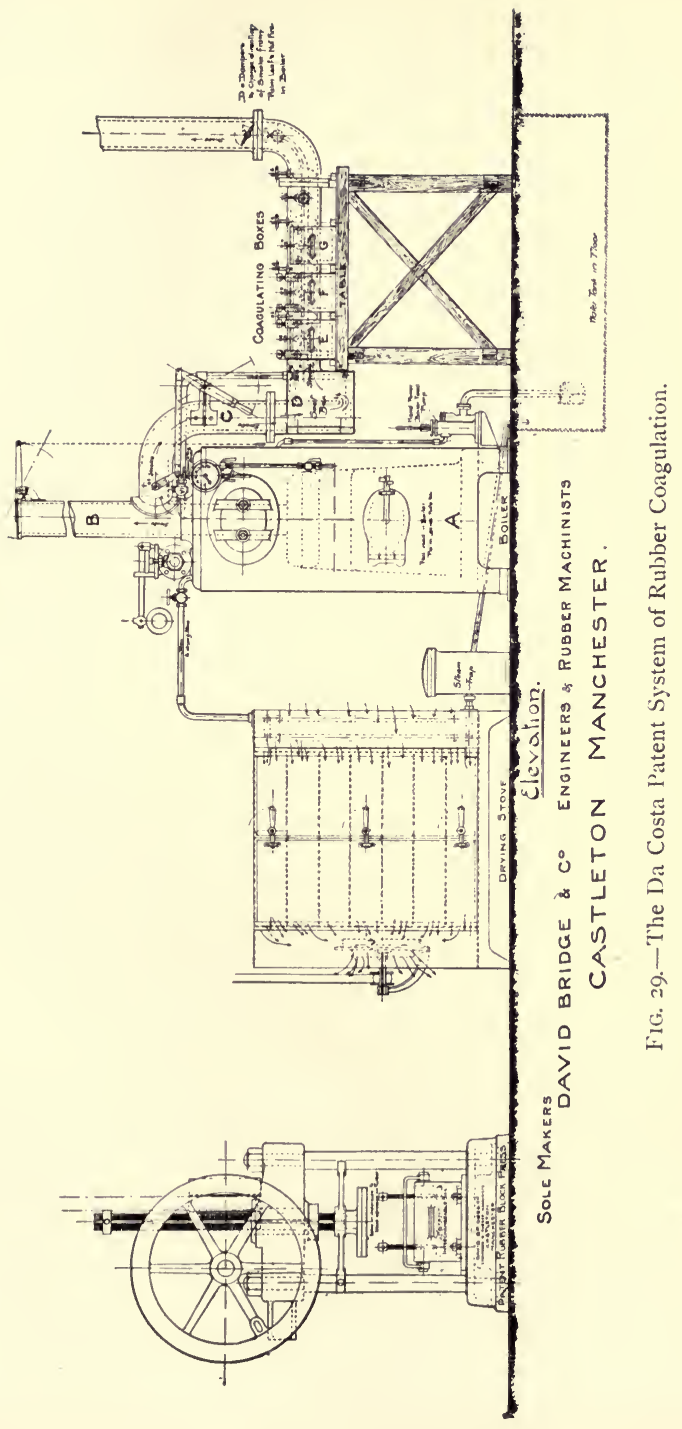


Smoked plantation rubber has been generally well reported upon, and buyers state it appears stronger than the unsmoked product.

Such rubber is obviously only antisepticised superficially, and consequently not sufficiently protected against the various agents responsible for putrefaction, tackiness, \&c.

For this to be effectually performed it is necessary to follow more closely the method adopted by the Amazonian collectors and smoke the latex. An apparatus for this purpose has been recently placed on the market (see Fig. 29).

"This plant, which is the result of practical experiments and tests by Mr Da Costa, and is made by Messrs David Bridge \& Co., the well-known rubber engineers of Castleton, Manchester, needs no chemicals whatsoever, so long as tropical forest woods are available for heating the boiler, as well as green foliage of palms for generating smoke in the boiler furnace.

"The coagulating and smoking by means of this plant is the simplest of all operations in the rubber industry, and may be performed by any inexperienced hand, the process being as follows :-

"The latex, being brought from the field, is strained if it is found to contain mechanical impurities, and then poured into the coagulating tanks. Steam is meanwhile being raised to about 30 to $35 \mathrm{lbs}$. in the boiler, forest woods alone being used for fuel. On to the burning wood in the furnace are then thrown green palm leaves, nuts, or any green twigs of tropical trees, the distillation of $w$ hich produce acetic acid, whilst the fumes of the green foliage would be found to contain creosote to some extent. These fumes are accumulated in a special receptacle after being cleared of cinders, \&c., and are then forced into the coagulating tanks by a steain injector.

"The force of the steam violently agitates the latex, and during this operation every particle of it is reached by the smoke. In about ten minutes, or rather more if the quantities to be dealt with are very large, the caoutchouc globules coagulate and separate from the lyes and rise to the surface.

"The coagulated substance, after being allowed to cool off in the tanks, is afterwards taken to a small press and turned out in the shape of flat block rubber. These, in their turn, are then re-blocked into cube form, and after being dried, either in a 
stove or vacuum, are ready for shipment. If the flat blocks are only lightly compressed into the form of cubes, whilst still being sufficiently air-tight in the centre to prevent discoloration setting in, they can be easily torn asunder by the manufacturers and used in their machines, without the extra labour of previously cutting them into convenient sizes.

"Rubber prepared in this way retains all the native elements, as regards resiliency and tensile strength, of fine hard native Para, and will last as long as the wild rubber-if kept in a crude state, for years.

- "It is claimed for this coagulating plant, therefore, that it not only has the advantages of dispensing with the assistance of chemical agents in a liquid form, but also allows the producer to send to the market the only preparation that satisfies all the rubber manufacturers' requirements at the various manufacturing centres throughout the world. In addition to this, the inventor claims that it also possesses the unique property of being the only apparatus which can convert the latex of the Castilloa clastica into a rubber of equal market value, appearance, and colour to that of the best Para sorts exported from Brazil."

\section{Coagulation with Formic ACid.}

The principal objection to the use of formic acid as a coagulant has been its greater cost than that of the acids more generally employed, but less is required to effect coagulation, and it has valuable antiseptic properties.

It is now reported that formic acid is being manufactured sy'nthetically on a large scale by the Nitrifabrik Aktiengesellschaft, of Cöpenick, at a low cost, and it is considered that it will therefore prove a valuable substitute for acetic and similar acids in view of its antiseptic properties. Spence, who has conducted experiments in the coagulation of Hevea latex with this reagent, states:* "For the sample of latex in question it was found that as the result of three separate determinations, using six samples of latex, to which measured quantities of 5 per cent. formic acid were added, that the most rapid and complete coagulation, resulting in a product of standard quality, was obtained when to

* India-rubber Journal, pp. 425-426, 20th April 1908. 
each 500 c.c. of latex 20 to 25 c.c. of a 5 per cent. formic acid solution were added." And in summing up the results of his cxperiments: "(a) Much less formic acid than acetic acid is required; formic acid, having more than double the value of acetic as a coagulant, is more economical from a practical standpoint. (b) Formic acid is of marked value as an antiseptic agent, preserving the raw moist samples of rubber prepared by means of it from putrefaction and decomposition. It would appear, indeed, that in this condition formic acid combines the properties of acetic acid and creosote, and could be employed, therefore, with advantage where coagulation by means of acetic and creosote is indicated (moist block rubber)."

\section{Discoloration of Rubber and Oxidising Enzymes.}

Lack of uniformity as regards the colour of plantation rubber is often the cause of inferior prices being realised, and rubber brokers state that this is one of its primary defects.

Kelway Bamber is of opinion that discoloration is due to the action of an oxidising enzyme on the soluble organic matter in the latex. He states that the enzyme may be destroyed, and the colour of the rubber uniformly maintained by heating the latex or the rubber after coagulation.

By the first method the latex should be raised to a temperature of $167^{\circ}$ Fahr. by the incorporation of steam.

For the destruction of the enzyme in the rubber, immediately after it leaves the rolling machine, it should be immersed in hot water, i.e., temperature about $170^{\circ}$ to $180^{\circ}$ Fahr., for several minutes. The heated rubber should then be re-rolled and again immersed in hot water for a short time.

In Vol.iii.No. 4 of the Bio-Chemical Journal, Spence contributes a valuable article on the presence and function of oxydases (i.e., oxidising enzymes) in latex, wherein he states that the darkening in colour of raw rubber is due to an oxydase which is associated with the protein or the so-called insoluble constituent of the rubber.

\section{“TACKINESS.”}

The sticky or "tacky" condition so commonly associated with the lower grades of rubber and which has frequently been 
observed on cultivated Para rubber, is largely due to the action of bacteria on the proteids and, perhaps, some of the gummy and sugary matters present in the rubber. A similar condition is, however, frequently observed in rubber which contains a large percentage of resinous and oily substances, which have a low melting point.

The tackiness due to micro-organisms is readily infectious, and care is therefore necessary to separate sound rubber from affected rubber.

Tackiness may be often observed on the latex left adhering to collecting vessels, tapping knives, \&c., so that it is necessary to keep all articles employed in the tapping, collection, and preparation of rubber scrupulously clean, with a view to avoid infection.

Thorough drying and antisepticising the rubber are, however, the most effectual means of combating this evil. 


\section{DRYING AND PACKING RUBBER FOR EXPORT.}

Drying the Rubber.

WHATEVER system of preparing the rubber be employed it is essential to thoroughly dry it previous to shipment. In the moisture laden atmosphere of the tropics this naturally takes considerable time unless artificial aid be called in. It has already been shown that the presence of moisture in the rubber encourages putrefaction and "tackiness." The sooner it is expelled from the rubber the better; still, high temperatures are not advisable, as unvulcanised rubber is very sensitive to high temperatures, which cause softening, a loss of nerve, and bubbles to form on the surface of the rubber, which spoil its appearance. Para rubber will bear more exposure to heat without detrimental effects than those grades which contain a larger percentage of resinous and oily matters, but it is considered that a higher temperature than $110^{\circ} \mathrm{Fahr}$. is liable to prejudice it. The commonest method in vogue is that of passing over the rubber a current of hot dry air.

Drying houses similar to those employed in the manufacture of cocoa have been advantageously employed on some estates. In these hot air is drawn from a furnace situated at one end of the building through iron ducts by means of fans fixed at the opposite end of the building. A fairly constant temperature can be obtained, and in the case of cocoa drying it is often maintained at $110^{\circ} \mathrm{Fahr}$. The rubber in these is usually placed on shelves made of wire netting.

Drying houses on the same principle as flue-curing tobacco barns could also be satisfactorily employed, providing sufficient ventilation were supplied. In these the furnace is built of bricks. It is placed outside the building and sunk in the ground in such a manner that the flue enters the building just above the floor level, 
The flue is composed of heavy black iron from 12 to 15 inches in diameter, and runs round the building at about 3 feet from the walls. It issues from the same wall by which it enters the building, but at the opposite corner, where it is connected with a smoke stack and thus runs round three sides of the building. In a building measuring $20 \mathrm{ft}$. by $20 \mathrm{ft}$. by $20 \mathrm{ft}$. a temperature up to $110^{\circ}$ Fahr. could be maintained if desired with a single flue such as that described. Larger buildings would require more flues in proportion to the increase in size. Shelves of wire netting on which to place the rubber could also be arranged all round this building.

Drying of rubber by calcium chloride has also been suggested. Ridley states that the expense is not great, as calcium chloride is quite cheap and practically lasts for ever.

\section{VAcuum Drying.}

Vacuum drying is the most expeditious method, and is being employed on many rubber estates.

By the adoption of this method moisture can be rapidly extracted from the rubber without exposing it to injuriously high temperatures, and the process is quite independent of climatic conditions.

Less fuel is required than by the hot air drying method, as in the latter it is estimated that only about one-third of the heat conveyed by the air is given up to the rubber since the air has to pass too quickly through the drying-rooms to take up all the moisture of which it is capable. On the other hand, if the hot air be made to travel slowly with a view of taking up a greater percentage of moisture, the drying of the rubber is considerably retarded. The hot air likewise frequently contains dust which is liable to be deposited on the moist surface of the rubber.

Far less space is required for vacuum drying than for hot air drying, as in the latter case it is necessary to leave sufficient space between the rubber blocks or sheets for a free current of air to pass around them. Hot air dried rubber is frequently hard on the surface, whereas the reverse condition is obtained in a vacuum dryer.

The enormous economy which is effected in fuel by vacuum drying will be better appreciated if it be borne in mind that 
under vacuum the boiling point of water is reduced from $212^{\circ}$ Fahr. to about $95^{\circ}$ Fahr.

\section{The Passburg Vacuum Drying Chambers.}

Passburg vacuum drying chambers are already in use on several Para rubber plantations in Ceylon and Malaya. It is intcresting to note that two are in use at the Lanadron Estate (of "block rubber" fame), Muar, Malay, one at the famous Culloden Estate, Ceylon, and also at the Vallambrosa and Highlands and Lowlands Estates.

We are indebted to $\mathrm{Mr} \mathrm{J}$. Livingston, the British and Colonial agent for Passburg drying apparatus, for the following particulars in regard to them :-

"The vacuum drying chamber is designed to remove the water rapidly and at low temperatures especially from such materials as, on account of their sensitiveness to heat, could not be dried by methods hitherto used without altering their chemical composition, or required to be subjected to the drying process for too long a time for practical and economical purposes, and these difficulties increased when the articles to be dried were of perishable nature. But also for such substances as can be dried without injury under a higher temperature, this dryer can be used with great saving in time, fuel, cost of plant, and working expenses.

"The dryer consists of a cast or wrought iron chamber or cylinder which is closed hermetically at one or both ends by doors.

"The chamber contains a number of closed steam or heating shelves or pipes (also for hot-water heating) arranged one above the other, in which small pipes for the admission and exit of the heating steam or hot water are fitted. The shelves are, as a rule, made strong enough for a test pressure of $90 \mathrm{lbs}$., the pipes for a higher pressure.

"On these are placed iron, copper, galvanised perforated iron or earthenware trays, or trolleys, which contain the material that is to be dried. After the door of the dryer, which is fitted with an india-rubber joint, has been closed, a high vacuum of at least 28 inches of mercury or more is created by means of an air pump, whilst exhaust or live steam or hot water passes through the 
DRIING AND PACKING RUBBER FOR EXPORT.

heating shelves or pipes. At a very moderate temperature of the material that is to be dried-about $95^{\circ} \mathrm{Fahr}$. ( $35^{\circ}$ Cent.)

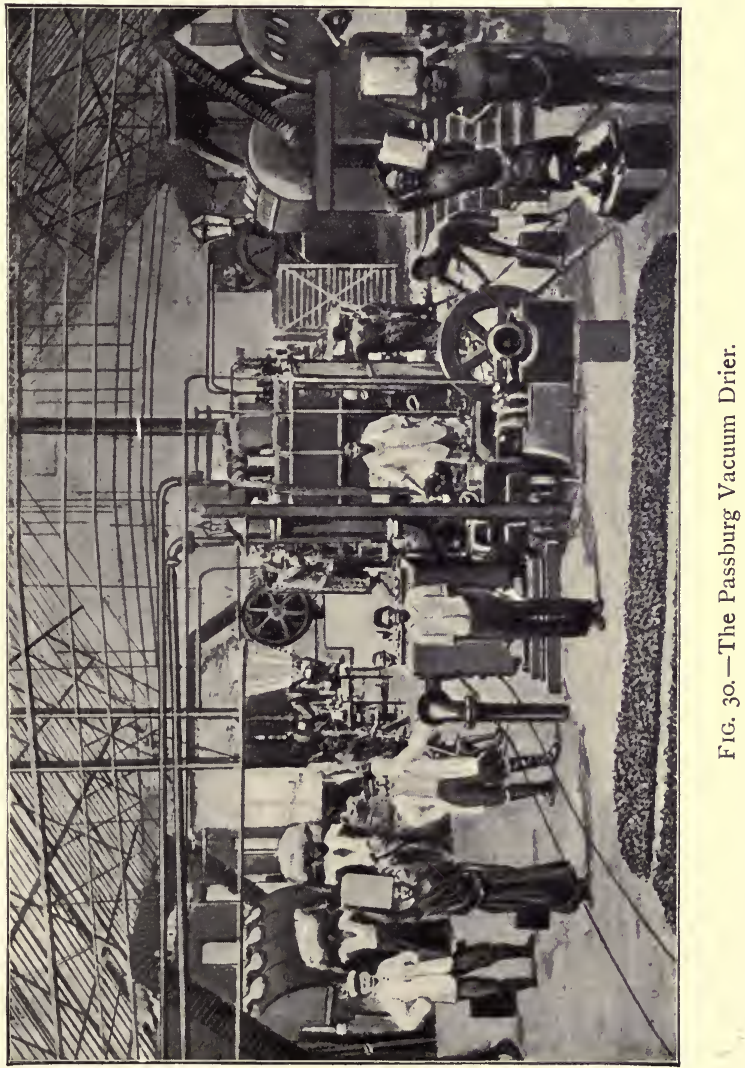

-the water, owing to the vacuum, begins to evaporate briskly out of the substances, and the latter dry rapidly.

"Even materials which are very difficult to dry, and which by 
other methods it takes days to dry, or which cannot be dried at all, when placed in these chambers are usually dry after a few hours, without the substances being in the least impaired through being overheated.

"The charging of the chamber is simple and easy, the working very clean and reliable. The temperature can be regulated by valves in the steam pipes. The drying is absolutely certain and is quite independent of climatic conditions.

"By using hot water for heating, and by means of an air pump giving a high vacuum, the evaporation of the water contained in the materials that are to be dried takes place at as low a temperature as $63^{\circ}$ Fahr. ( $17^{n}$ Cent.).

"The rubber sheets, biscuits, or crêpe are spread evenly three or four layers deep on trays, which are then placed between the heating shelves of the dryer. By means of a small air pump a vacuum of about 28 to $28 \frac{1}{2}$ inches is produced within a few minutes of the closing of the swing hinged door. This pump requires from $I_{2} \frac{1}{2}$ to $2 \mathrm{H} . \mathrm{P}$. at first, but in a few minutes $\frac{3}{4}$ or I H.P. suffices to maintain the vacuum.

"The steam that has been used to drive the pump is passed to the heating shelves of the chamber and is sufficient to dry the rubber.

"When the temperature of the wet rubber reaches about $90^{\circ}$ Fahr., evaporation most rapidly takes place. The vapour passes to a small surface condenser, the pump being a dry one.

"The temperature of the drying rubber remains constant, slowly rising towards the completion of the drying. A charge is dried in from $I_{\frac{1}{2}}$ to 2 hours, and four to five charges can be dried within Io to 12 hours.

"Vacuum dried rubber remains much more elastic and softer to the touch than air dried; this is owing to the absence of the air with its oxygen, its surfaces have not become hardened or oxidised. The only heat required is the steam to drive the air pump ; its steam cylinder is $4 \frac{5}{16}$ in. diameter by $6 \frac{5}{16}$ in. stroke, or say steam equivalent to about I H.P.

"The drying is quite independent of climatic conditions, and the space occupied is very small.

"The chamber, pump, and condenser are erected and tested in the works for air and steam tightness. The pump and condenser are packed and sent complete ready for placing in 


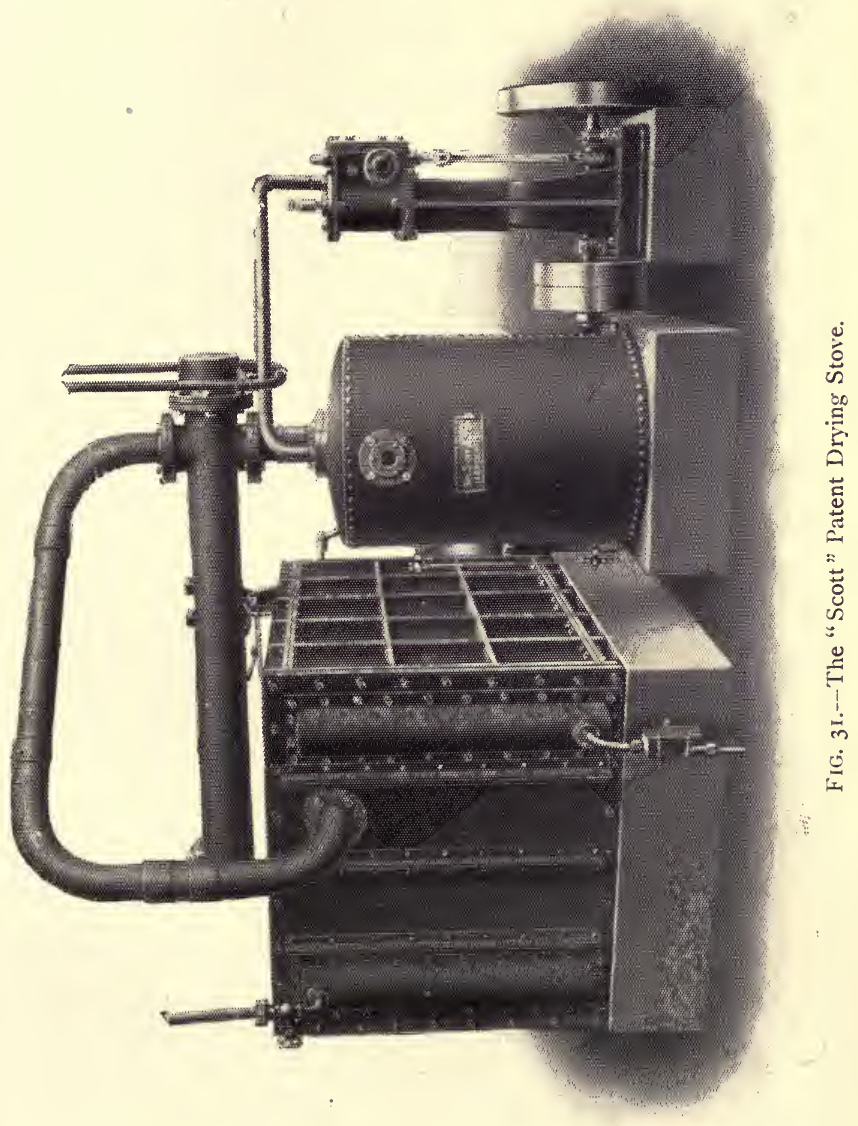


position. The chamber has the door and shelves removed, which are packed separately, so reducing the weights to three named on the quotations. Detailed drawings and instructions are sent as to erecting and setting to work, and no trouble is experienced in doing so. The connecting pipes depend upon the placing of the chambers, pump, and condenser to suit local arrangements, and are best obtained locally after the items are in position.

"If the estate is remote from an engineer's, then Mr Passburg could, as he often does, arrange the parts he considers best, and supply and fit the connecting pipes, sending a liberal allowance of piping, valves, bends, joints, \&c., for connecting up to boiler, cooling water supply, waste steam, \&c., furnishing a drawing so that the items can be placed to suit the piping.

"The additional price for such pipes and fittings if ordered with the plant is $£ 37$ for No. 9 size.

"Double sets of trays are provided, so that whilst one set is within the chamber the attendant can be emptying the other set of the dried and refilling with wet rubber, an exchange of trays thus occupying a few minutes only.

"No. 9 size receives about 140 lbs. of wet rubber per charge; No. I2, another usual size for plantations, about 190 lbs. per charge."

\section{Shaw's Rubber Drying Stoves.}

The writer is also indebted to Messrs Francis Shaw \& Co. for the illustration and particulars of their "Scott" patent rubber drying stove (Fig. 31).

These stoves are now largely used for drying rubber on the plantations. They are made in the following sizes :-

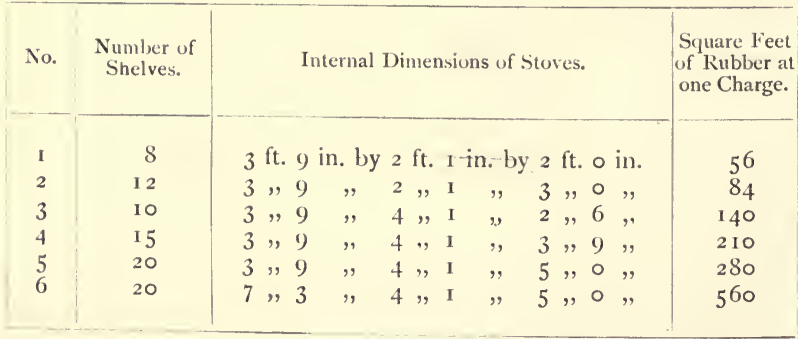




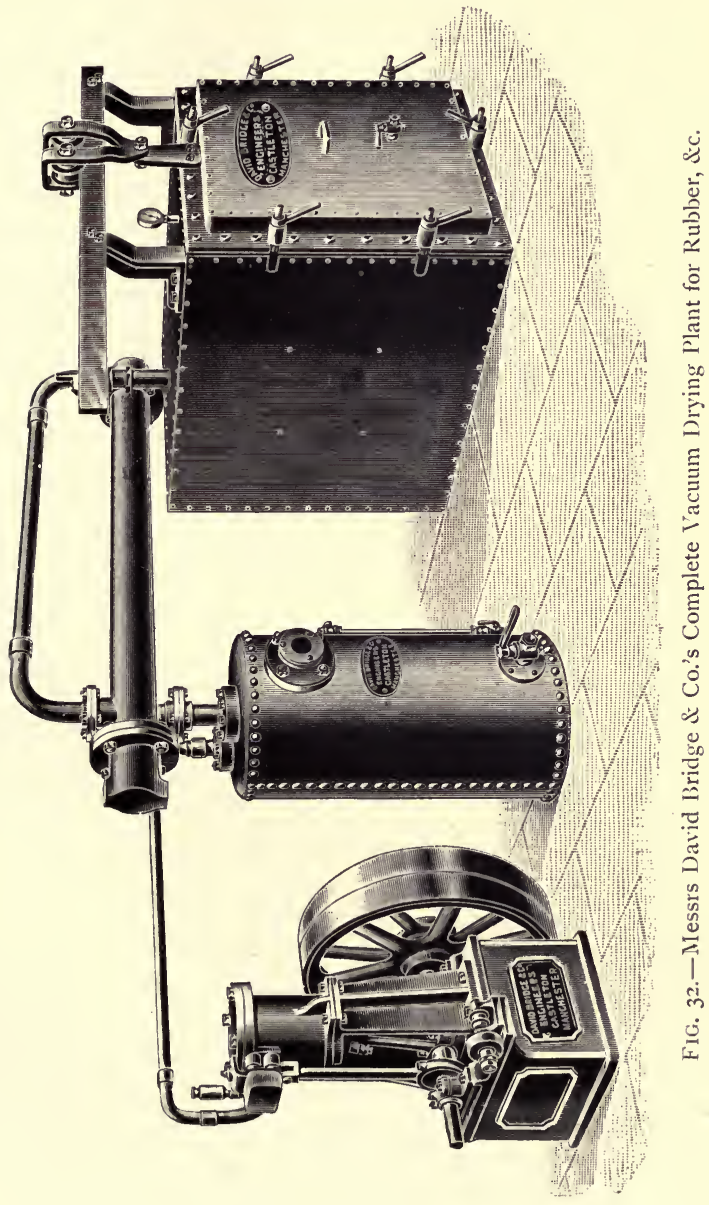


Stoves Nos. I to 4 require a I N.H.P. boiler, and Nos. 5 and 6 require a 2 N.H.P. boiler.

The number of square feet of rubber at each charge is calculated on the shelves being about $2 \frac{1}{4}$ inches apart in each case. This is suitable for crêpe, biscuit, or worm rubber, and if required for drying rubber in blocks, the distance apart of the shelves will be increased to suit the sizes of blocks used.

We may state that the areas given refer to one side of the shelves only on which the rubber is placed, and does not take into account the drying surface of the underside of the shelves. The inspection fittings of this apparatus enable the operator to watch the progress of the drying. The stoppage of the flow of water driven off from the rubber indicates when the process is complete.

\section{BRIDGE'S VACUUM DRIER.}

Another form of a vacuum drying plant is shown in Fig. 32 .

\section{PACKING RUBBER FOR EXPORT.}

The importance of keeping rubber dry and protecting it from bright light during the time which elapses between manufacture and despatch to market will be apparent from the preceding remarks. Good stout wooden cases should be used in packing, as rubber contracts in transit, and when the cases containing it are roughly handled the sides are liable to be knocked out. Ordinary tea-chests with an iron rim have proved satisfactory.

Carefully grade all rubber; light and dark coloured samples of each grade should not be mixed. To prevent the danger of contaminating sound with "tacky" rubber they should be kept separate. No packing material such as paper should be used which is liable to adhere to the rubber.in transit, and the interior of cases should be free from loose splinters, shavings, saw-dust, \&c., for a similar reason. To prevent dust and dirt entering the cases and adhering to the rubber, wax-paper might be beneficially employed.

The loss in weight of plantation rubber in transit varies between $\frac{1}{4}$ and 3 per cent.

"Fine Para" is usually received in packages weighing from 280 to 300 lbs., but brokers suggest that packages of plantation rubber should weigh from i to $2 \mathrm{cwt}$. each. 


\section{CHAPTER XIII.}

YIELD OF PARA RUBBER FROM CULTIVATED

TREES.

TIIE amount of rubber which Para trees of a given age may be expected to yield is a point about which it is impossible to give any really accurate data at the present time. To obtain this information, careful records will have to be kept for a long period, of trees growing in different countries and under various conditions. Such statistics as are available will be of interest.

\section{Ceylon.*}

"The late Dr Trimen commenced in I888 to tap one of the original trees at Heneratgoda, then nearly twelve years old and 5012 inches in girth a yard from the ground.

"It was tapped on seven days between $25^{\text {th }}$ January and I 5 th February, yielding $17 \frac{1}{4} \mathrm{oz}$. of rubber; on six days between 2oth July and 29th August, yielding 7 oz.; and on four days between 6th and 2oth December, yielding $4 \frac{1}{2}$ oz., a total of $\mathrm{I} \mathrm{lb}$. I $23 \mathrm{oz}$. The same method was followed in alternate years, with results as shown below :-

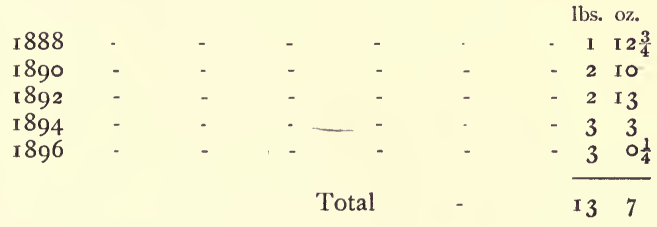

"The average yield of this tree from the twelfth to the twentyfirst year is thus almost $\mathrm{I} \frac{1}{2} \mathrm{lb}$. per annum."

An illustration of this tree is given (Fig. 2). It is growing on poor, gravelly soil, a by no means ideal spot for its successful cultivation. In fact, I saw trees in Ceylon six or seven years younger better developed than this tree.

* Royal Botanic Gardens, Ceylon. Circular No. 4. 
When in Ceylon I was shown three Para trees (age unknown) which had recently been tapped and had yielded 2 I lbs. of rubber, and they exhibited no ill effects.

\section{Malay Peninsula.}

$\mathrm{Mr}$ Arden* gives the following results obtained from tapping trees at ages varying from three and a half to ten years :-

lbs. oz.

\begin{tabular}{|c|c|c|c|c|c|c|c|}
\hline \multicolumn{3}{|c|}{$3 \frac{1}{2}$-year-old trees gave } & - & - & - & & I. 54 \\
\hline 4 & , & , & - & - & - & o & 2.25 \\
\hline 7 & , & ", & - & - & - & ० & 14.275 \\
\hline 8 & , & , & - & - & - & 1 & 0.75 \\
\hline IO & , & , & - & - & - & 2 & 4.0 \\
\hline
\end{tabular}

The largest amount of dry rubber obtained from a ten-yearold tree was 5 lbs. $6 \frac{1}{2}$ oz. The tree was 5 feet 3 inches in circumference, and was tapped with herring-bone incisions renewed on fourteen alternate days.

A tree $\dagger$ in the Botanic Gardens, Penang, has yielded the following quantities of rubber year by year since 1897 :-

Date of Tapping.

June 1897

November and December 1898

April and May I 899

November and Iecember 1899 -

October and November 1900

August and September rgor

May I 903
Approximate

Age of Tree Yield. in Years.

lbs. $\mathrm{oz}$

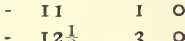

$\begin{array}{lll}-122 & 3 \\ - & 13 & 2\end{array}$

- $13 \frac{1}{2} 34$

- 142312

- 1522

- $16213 \frac{1}{4}$

- $16 \frac{1}{2} 36$

Mr Francis Pears + gives the following account of tapping in Perak :-

"In case you have not received previous information, I append particulars of the yield of two cultivated Para trees at Gapis Estate, in Perak, reputed to be twenty-five years old. The tapping was conducted by $\mathrm{Mr}$ Baxendale, and extended over two months, and was done evidently with the intention of procuring a maximum yield.

* Report upon Hevea brasiliensis in the Malay Peninsula.

+ Straits Settlements Agricultural Bulletin.

+India-rubber Journal, and Feb. 1903 . 
" Girth at I yard from the ground

Tree No. I. Tree No. 2.

Yield of clean rubber (dry) -

Yield of scrap rubber (dry) -

\section{Total}

$\begin{array}{rrrrrr}89 & \text { in. } & & 56 & \text { in. } \\ \text { 1bs. } & \text { oz. } & & \text { 1bs. } & \text { oz. } \\ \text { I } 5 & \text { I } 2 & & \text { I I } & 2 \\ 2 & 4 & & \text { I } & 8 \\ & & & \end{array}$

"Tree No. I had never been previously tapped, and was worked from three channels, whereas tree No. 2 was worked from two channels only, and was tapped during I90I, and yielded 3 lbs."

Tapping experiments conducted in Perak in 1900, on eightytwo trees averaging fourteen years old, produced 34I lbs. of rubber, or an average of $4.2 \mathrm{lbs}$. per tree.*

Six-year-old trees on the Inch Kenneth Estate, Kajang, Selangor, were tapped in 1902 on fifteen consecutive days, and yielded an average of $\mathrm{I} \mathrm{lb} .2 \mathrm{oz}$. of dry rubber per tree. $\dagger$

Four fourteen-year-old trees, growing in the Bukit Sebukor Forest, Malacca, were tapped in April and May 1903, and yielded Io lbs. 2 oz. of cake rubber, and $2 \mathrm{lbs} .2 \mathrm{oz}$. of scrap rubber, i.e., an average of $3 \mathrm{lb}$. I oz. per tree.

\section{Gold CoAst, West AfricA.}

Four ten-year-old trees growing in the Gold Coast Botanic Garden, which is situated 1,500 feet above sea-level, were tapped for the first time in 1903, and yielded 4 lbs. 3 oz. of dry rubber, or an average of $\mathrm{I} \mathrm{lb} . \mathrm{O} \frac{3}{4} \mathrm{Oz}$. per tree.

This yield must not, however, be taken as a criterion of the anticipated yield for trees of this age cultivated in West Africa. The trees above referred to are growing in poor, gravelly soil on the top of a hill, a position unfavourable for their proper development. I am quite convinced that the conditions obtaining in many parts of West Africa are quite as favourable for the successful cultivation of Para rubber as those in Ceylon or the Malay Peninsula.

From the tapping results given above, it will be understood how difficult a matter it is to arrive at any really satisfactory estimate of the amount of the yield to be expected from cultivated Para trees. Providing the site for the plantation has been

* Report by Mr Derry, Superintendent of Government Plantations, Perak, I900.

† Straits Settlements Agricultural Bulletin, Aug. 1902. 
carefully selected, and cultural details attended to, about 50 per cent. of the trees should be ready for tapping at the end of the sixth year; but whether tapping should take place must of course depend upon the price of labour, as only an average of $\frac{1}{2}$ lb. of dry rubber can be expected from each tree tapped at that age.

The following year practically every tree on the plantation should be rcady for tapping, and the average yield would be about $\frac{3}{4} \mathrm{lb}$., and the following year $\mathrm{I} \mathrm{lb}$.

These figures are, of course, only very approximate, and much below the returns obtained on many estates, both in Ceylon and in the Malay Peninsula.

Many pages might be filled with records of rubber obtained by different tapping methods from trees of various ages in different countries.

Really astonishing amounts of dry rubber have been obtained in a given year from trees of various ages; for examplc: sixyear-old trees have yielded 2 lbs., eleven-year-old trees I6 lbs., and twenty to twenty-five-year-old trees $25 \mathrm{lbs}$. The reports of such results, although most acceptable to the company promoter, are distinctly misleading. In many cases the high yields obtained have been from individual trees and by drastic tapping methods. Alongside of these yields it would be instructive to read the yield of such trees in subsequent years, and also the yield of the trees growing under like conditions but not so severely tapped. In view of the numerous factors which affect the yield of Hevea trees it is almost impossible to even fairly accurately estimate what the average yield of a plantation of these trees will be during any particular year. This must of necessity be largely affected by soil and climatic conditions, methods of cultivation, tapping methods adopted, distance the trees are planted apart, and the extent to which previous tappings have been carried out.

Providing these conditions be favourable, an average annual yield of $\mathrm{I}_{4} \frac{3}{\mathrm{l}} \mathrm{b}$. of dry rubber per tree should be obtained from the seventh till the twelfth year of its age. What the yield of trees, tapped annually from the sixth till the twelfth year, will be during the thirteenth and subsequent years it is too early to state, but probably the yield will gradually increase annually till $2 \frac{1}{2} \mathrm{lbs}$. of rubber per tree are obtained. 
Far larger yields have been obtained, but it remains to be proved whether such amounts of rubber can be extracted by the present methods of tapping in vogue without unduly injuring the trees.

The fairest estimate can be obtained by studying the yield from a large number of trees. The following statistics have therefore been compiled to show the rubber harvested during the last three years by various rubber planting companies. Unfortunately it is neither possible to indicate the age of the trees nor the methods of tapping employed. We may, however, safely assume that, in view of the comparative infancy of the Hevea rubber planting industry, the average age of the trees cannot be more than seven or eight years, and as, in the majority of instances, it would be directly antagonistic to the planter's interest to unduly over-tap his trees, reasonable moderation was observed in tapping operations. The writer has collected the following returns from a large variety of different sources, and has exercised due care to ensure accuracy; he therefore trusts that interested parties will accept his apologies if errors have crept in.

1905.

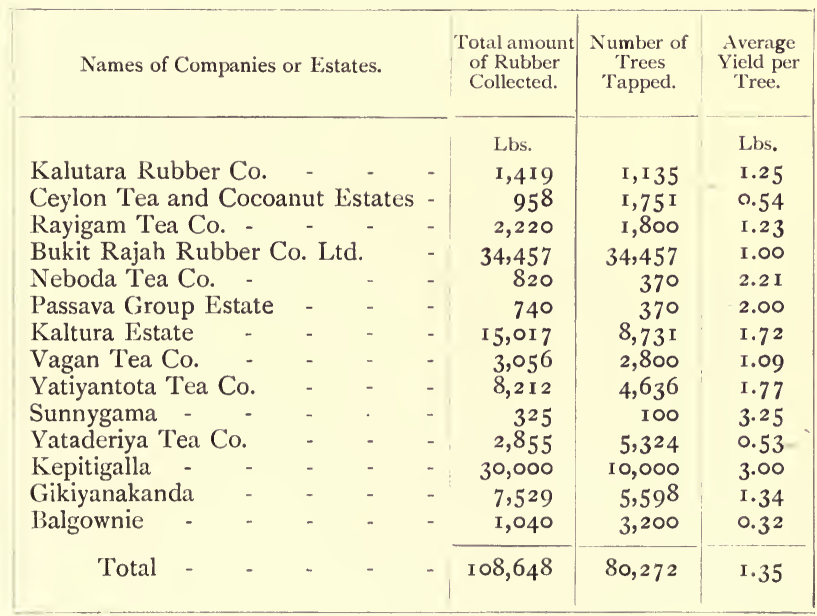


I906.

\begin{tabular}{|c|c|c|c|c|c|}
\hline \multicolumn{3}{|c|}{ Names of Companies or Estates. } & $\begin{array}{c}\text { Total anount } \\
\text { of Rubber } \\
\text { Collected. }\end{array}$ & $\begin{array}{c}\text { Number of } \\
\text { Trees } \\
\text { Tapped. }\end{array}$ & $\begin{array}{l}\text { Average } \\
\text { Yield per } \\
\text { Tree. }\end{array}$ \\
\hline & $\begin{array}{l}\text { Lbs. } \\
3^{2,693}\end{array}$ & 11,348 & $\begin{array}{l}\text { Lbs. } \\
2.88\end{array}$ \\
\hline \multirow{2}{*}{\multicolumn{6}{|c|}{$\begin{array}{l}\text { Highlands and Lowlands Para } \\
\text { Rubber Co. }\end{array}$}} \\
\hline & & $-\quad-(a)$ & 95,333 & 38,639 & 2.46 \\
\hline$"$ & & $" \quad(b)$ & 5,742 & 807 & $7.1 \mathrm{I}$ \\
\hline Kalatura C & & & $38,95^{2}$ & 39,874 & 0.97 \\
\hline Anglo-Malay & 1.td. - & - & 8,126 & 4,379 & 1.85 \\
\hline Cicely Rubbe & Estates & - & $\begin{array}{r}100,019 \\
0,184\end{array}$ & $\begin{aligned} 60,991 \\
6,919\end{aligned}$ & $\begin{array}{l}1.63 \\
\text { I. } 32\end{array}$ \\
\hline Bukit Rajah & Rubber Co. & Ltd. & $\begin{array}{r}9,104 \\
\text { I } 8,982\end{array}$ & $88,34 \mathrm{I}$ & $\begin{array}{l}1.32 \\
1.34\end{array}$ \\
\hline Malacca Rub & ber Plantati & ions Ltd. - & 14,500 & 30,000 & 0.48 \\
\hline Anglo-Americ & can Direct ' & Tea Trading & $3,28 \mathrm{I}$ & 1,172 & 2.79 \\
\hline Blackwater & $-\quad-$ & 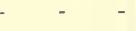 & I 3,033 & 8,744 & 1.49 \\
\hline Pelmadalla & - & - & 602 & 500 & 1.20 \\
\hline Yatiyantota & - & - & 8,790 & $4,63^{6}$ & 1.89 \\
\hline Shelford & - & - & $6,8 \circ 5$ & $9,63^{6}$ & 0.70 \\
\hline Sandycroft & - & - & I 6,178 & I 3,046 & 1.24 \\
\hline Yataderiya & - & - & 8,025 & 5,947 & 1.34 \\
\hline Ledbury & - $-\dot{1}$ & $-\quad \cdot{ }^{-}-$ & 2,057 & 3,755 & 0.54 \\
\hline Asiatic Rubb & er and Prod & uce Co. Ltd. & 8,045 & $5,27 \mathrm{I}$ & $1.5^{2}$ \\
\hline Eastern Prod & uce and Est & ates Co. Ltd. & $22,55^{8}$ & 20,735 & 1.08 \\
\hline Golden Hope & Rubber Es & tates Co. Ltd. & 2,640 & 880 & 3.00 \\
\hline $\begin{array}{l}\text { Kepitigalla R } \\
\text { Patalang Rul }\end{array}$ & $\begin{array}{l}\text { Uubber Esta } \\
\text { bber Estate }\end{array}$ & $\begin{array}{l}\text { tes Co. Ltd. } \\
\text { s Syndicate }\end{array}$ & 46,6 I 2 & 17,572 & 2.65 \\
\hline Ltd. - & $-\quad-$ & $-\quad-\quad-$ & 43,301 & $39,33^{6}$ & I. 10 \\
\hline Total & - & - & $605,45^{8}$ & $412,5^{28}$ & 1.47 \\
\hline
\end{tabular}

1907.

Names of Companies or Estates.

\begin{tabular}{|c|c|c|}
\hline $\begin{array}{l}\text { Total amount } \\
\text { of Rubber } \\
\text { Collected. }\end{array}$ & $\begin{array}{l}\text { Number of } \\
\text { Trees } \\
\text { Tapped. }\end{array}$ & $\begin{array}{l}\text { Average } \\
\text { Yield per } \\
\text { Tree. }\end{array}$ \\
\hline Lbs. & & Lbs. \\
\hline${ }_{19}, 78_{1}$ & 16,782 & I. 17 \\
\hline 2,934 & $\mathrm{I}, 500$ & I.95 \\
\hline $3^{2,}, 75$ & I 2,335 & 2.60 \\
\hline 9,2 I I & $5, \circ 35$ & I. $8_{3}$ \\
\hline I 33 & II 7 & I. I 3 \\
\hline I, 500 & I,7 I 2 & 0.87 \\
\hline I I, 548 & 20,000 & 0.57 \\
\hline $131,25^{2}$ & 48,823 & 2.68 \\
\hline 208,534 & 106,304 & \\
\hline
\end{tabular}

Bertram Rubber Co. Ltd.

Castlewood Rubber Co. Ltd.

Federated Malay States Rubber Co. Itd.

Attapadi Tea and Rubber Co.

Kelani Valley Tea Association

Sunnygama Ceylon Tea Estate Co. Ltd. -

Shelford Rubber Estate Ltd. -

Highlands and Lowlands Para Rubber Co. Ltd.

Carry forward 
YIELD OF PARA RUBBER FROM CULTIVATED TREES. I 5 I

I 907 -Continued.

\begin{tabular}{|c|c|c|c|}
\hline Names of Conipanies or Estates. & $\begin{array}{l}\text { Total amount } \\
\text { of Rubber } \\
\text { Collected. }\end{array}$ & $\begin{array}{l}\text { Number of } \\
\text { Trees } \\
\text { Tapped. }\end{array}$ & $\begin{array}{l}\text { Average } \\
\text { Yield } \\
\text { per Tree. }\end{array}$ \\
\hline Brought forward - - & $\begin{array}{c}\text { Lbs. } \\
208,534\end{array}$ & I 06,304 & Lbs. \\
\hline Anglo-Malay Rubber Co. Ltd. & 224,778 & 68,236 & 3.29 \\
\hline Balgownie Rubber Estates Ltd. & 10,642 & 8,000 & 1.33 \\
\hline $\begin{array}{l}\text { Cicely Rubber Estates - } \\
\text { Duckwari (Ceylon) Tea Plantation }\end{array}$ & I 9,069 & 8,020 & 2.37 \\
\hline 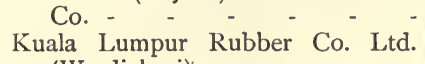 & 4 I 9 & 182 & 2.30 \\
\hline $\begin{array}{c}\text { (Wardieburi) } \\
\text { Kuala Lumpur Rubber Co. Ltd. }\end{array}$ & 9,2 I I & $5, \circ 35$ & I. 83 \\
\hline (Kent) - - - - - - & 29,868 & 9,466 & 3.16 \\
\hline Perak Rubber Plantations Ltd. & I 6,327 & I 2,600 & I.29 \\
\hline Sione Rubber Co. Ltd. - - & $8,3^{8} 5$ & 5,967 & I.40 \\
\hline Vallambrosa Rubber Co. Ltd. & $53,35^{8}$ & 147,101 & I.04 \\
\hline Total & $680,59 I$ & 370,9 I I & I. 83 \\
\hline
\end{tabular}

Several companies do not indicate in their reports the number of trees tapped, but instead, state the yield of rubber from a given acreage. A comparison of such reports for the year 1906 shows that the average yield of rubber per acre varied from $57 \mathrm{lbs}$. to I $5 \mathrm{I}$ lbs.

\begin{tabular}{|c|c|c|c|c|c|c|c|c|}
\hline 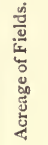 & 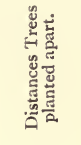 & 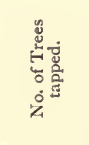 & 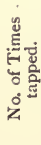 & 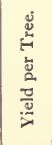 & $\frac{0}{\square}$ & 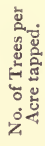 & 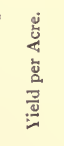 & Remarks. \\
\hline 60 & $\begin{array}{c}\text { Feet. } \\
24 \times 12\end{array}$ & 4,642 & 3 & $\begin{array}{l}\text { Lbs. } \\
2 \frac{3}{4}\end{array}$ & $\begin{array}{c}\text { Lbs. } \\
12,765\end{array}$ & 77 & $\begin{array}{l}\text { Lbs. } \\
212 \frac{1}{2}\{\end{array}$ & $\begin{array}{l}\text { Planted I } 899 \text { (about } \\
\text { I } 5 \text { otrees peracre) }\end{array}$ \\
\hline 150 & $10 \times 10$ & $\left\{\begin{array}{r}8,000 \\
28,301\end{array}\right.$ & $\left.\begin{array}{l}3 \\
2\end{array}\right\}$ & $1 \frac{1}{2}$ & 54,451 & 242 & 363 & $\begin{array}{l}\text { This field was } \\
\text { planted through } \\
\text { coffee in I } 898 \text {, } \\
\text { and thinned out } \\
\text { to } 260-270 \text { trees } \\
\text { pcr acre. }\end{array}$ \\
\hline 40 & $12 \times 10$ & 6,225 & 2 & I & 6,225 & 155 & I 55 & $\begin{array}{l}\text { Planted I } 1900 . \\
\text { Thinned to } 250 \\
\text { trees per acre. }\end{array}$ \\
\hline 680 & $12 \times 10$ & $\left\{\begin{array}{l}10,000 \\
60,820 \\
29,113\end{array}\right.$ & $\left.\begin{array}{l}3 \\
2 \\
1\end{array}\right\}$ & $\begin{array}{l}\text { I } \\
50 \%\end{array}$ & $\left.\begin{array}{r}70,820 \\
9,097\end{array}\right\}$ & I 47 & I $17 \frac{1}{2}$ & $\begin{array}{l}\text { Planted from } 1899 \\
\text { to } 190 \text {. Thinned } \\
\text { to } 250-270 \text { trees } \\
\text { per acre. }\end{array}$ \\
\hline 930 & $\ldots$ & I 47, IO I & $\ldots$ & $\cdots$ & 153,358 & $\ldots$ & $\cdots$ & $\ldots$ \\
\hline
\end{tabular}

Extracted from report of Vallambrosa Rubber Co. Ltd., for year ended 3 Ist March 1907. 
1907-8.

\begin{tabular}{|c|c|c|c|}
\hline Names of Companies or Estates. & $\begin{array}{l}\text { Total } \\
\text { Amount of } \\
\text { Rubber } \\
\text { Collected. }\end{array}$ & $\begin{array}{c}\text { Number of } \\
\text { Trees } \\
\text { Tapped. }\end{array}$ & \begin{tabular}{|c} 
Average \\
Yield \\
per \\
Tree.
\end{tabular} \\
\hline $\begin{array}{l}\text { Perak Rubber Plantations Ltd. - } \\
\text { Federated (Selangor) Rubber Co. Ltd. } \\
\text { Vallambrosa Rubber Co. Ltd. - } \\
\text { Bukit Rajah Rubber Co. Ltd. - }\end{array}$ & $\begin{array}{l}\text { Lbs. } \\
34,770 \\
23,618 \\
225,302 \\
163,521\end{array}$ & $\begin{array}{r}18,150 \\
27,483 \\
152,195 \\
89,295\end{array}$ & $\begin{array}{r}\text { Lbs. } \\
1.91 \\
.86 \\
1.48 \\
1.83\end{array}$ \\
\hline Total - & 447,211 & 287,123 & I. 55 \\
\hline
\end{tabular}




\section{CHAPTER XIV.}

\section{ESTABLISHMENT AND MAINTENANCE OF A PARA RUBBER PLANTATION.}

\section{CEylon.}

THE expenditure required for the establishment and upkeep of a Para rubber plantation is small in comparison with that required for plantations of many other products in the tropics.

Expenses will of necessity vary in different countries in proportion to the cost of labour, land, and transport. I- therefore propose to give estimates having reference to the two countries where Para rubber is at the present time most extensively cultivated. These are Ceylon and the Malay Peninsula.

\section{Rubber in Ceylon.*}

Cost of Opening Land, Distances to Plant, \&oc.

Ceylon figures : Rupee $=\mathbf{I s}$. 4 d. English money.

\section{First Year.}

I. Purchase of land, say 200 acres at Rs. 50 per acre

Rs. 10,000

2. Felling, burning, and clearing at Rs. 15 per acre -

3. Roads and drains at Rs. 12 per acre

4. Lining R. I, and pegs R. I, I $5 \frac{1}{2}$ by $I 5 \frac{1}{2}, 200$ to acre, at

Rs. 2 per acre -

5. Holing Rs. 4 and filling Rs. 3 at Rs. 7 per acre -

6. Cost of planting 45,000 at Rs. I 2 per 1,000 -

7. Nurseries and upkeep

8. Planting R. I and shading Rs. 2 at Rs. 3 per acre

9. Weeding, April to December, at Rs. 2 per month

ı. Bungalow, Rs. 2,500, lines, \&c., at Rs. 600 per acre

I I. Superintendent Rs. 3,000, Conductor Rs. 600

12. Tools and contingencies -

Total cost of opening 200 acres for first year 3,000 2,400

\begin{tabular}{rr}
- & 400 \\
- & 1,400 \\
- & 540 \\
- & 100 \\
$-\quad 600$ \\
$-\quad 3,600$ \\
$-\quad 3,100$ \\
$-\quad 3,600$ \\
\hline$\quad 250$ \\
\hline Rs. 28,990 \\
$=£ 1,926$
\end{tabular}

* By Francis J. Holloway. India-rutber Journal, gth May 1904. 
Second, Third, Fourth, Fifth, Sixth Years.

Supervision -

Weeding

Upkeep of roads and drains

Upkeep of buildings

Supplies

Sundries

$$
\begin{array}{lr}
\text { - Rs. } 3,600 \\
- & 2,400 \\
- & 300 \\
- & 250 \\
- & 200 \\
\hline & 250 \\
\hline
\end{array}
$$

Rs. $7,000=£_{466}$ I3 4

By five years -

Total cost of 200 acres to end of the sixth year, Rs. 63,990or, say, $£ 4,200$ - to bring 200 acres of land into the seventh year in rubber.

The same writer* estimates that in 1902 he collected 1,362 lbs. of good rubber and $60 \mathrm{lbs}$. of scrap rubber at an average cost of $4 \mathrm{~d}$. per $\mathrm{lb}$. This was made up as follows :-

Tapping and curing

Packing boxes and transportation Proportionate share of cost of an outfit of collecting tins, tapping knives, and coagulating tins

- Rs. 570.63 say $£ 38 \circ 9$

$$
3 \text { I.1 } 3,2 \text { I } 7
$$

Total cost of placing 1,362 lbs. of

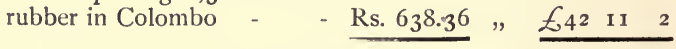

The following estimate of costs for the establishment and upkeep of a plantation of 20 acres was prepared for me in I902 by a well-known planter in the South Kalatura district, Ceylon:-

Cost of seeds, 8,000 at Rs. I 2 per I,000 Nurseries

Felling, Rs. 8 per acre

Roads and drains, Rs. $4.5^{\circ}$ per acre Lining and pegs, Rs. 2 per acre

Holing, I 8 inches deep, Rs. $2.5^{\circ}$ per acre Filling holes IVeeding first year, Rs. I.50 -

Carry forward

\begin{tabular}{rr} 
- Rs. & 96 \\
- & 70 \\
- & 160 \\
- & 90 \\
- & 40 \\
- & 50 \\
- & 25 \\
- & 30 \\
\hline
\end{tabular}

- Rs. $5^{61}=£_{37} 8$ 。 
Second year-

$$
\text { Brought forward - - Rs. } 5^{61}=£_{37} 8 \circ
$$

Weeding, 20 acres, at R. I per month $=$ Rs. $240 \quad-\quad$ - $\quad-\quad$ -

Watchman, Rs. 15 per month $=$ Rs. $180-\{420=2800$ Third year

Fourth year (weeding stopped, not necessary) -

Watchman, Rs. 180 , drains, Rs. $50=230-$ Fifth year

Sixth year

Seventh year ",

",

Cost up to seventh year
$420=28 \circ 0$

$230=15 \quad 6 \quad 8$

$230=15 \quad 6 \quad 8$

$230=\begin{array}{rll}15 & 6 & 8\end{array}$

$\frac{230}{\text { Rs. } 2,321}=\frac{15}{2154 \quad 14 \quad 8}$

It should be observed that the cost of superintendence is not charged in the above.

Mr F. Lewis, Assistant Conservator of Forests, Ceylon, gives the following estimate of cost of opening and planting 300 acres of forest land with rubber :-

Felling and clearing 300 acres of forest at Rs. I 2 per acre - Rs. 3,600 Lining 300 acres, 10 by 1o feet, at Rs. 2 per acre - - 600 Holing 300 acres, at 75 holes per coolie, at 40 cents,

$$
\text { 1 } 30,680 \div 75 \text { by } 40 \text { - }
$$

Filling and planting and carrying plants from nursery to holes,

300 per coolie at 40 cents, $130,680 \div 300$ by 40 -

Draining 300 feet of drains per acre at $\mathrm{I}$ cent per foot run

Lines for coolies, one shed of ten rooms of 12 by 10 feet,

mud walls and battacola roof, at Rs. 30 per room -

Roads for inspection, two miles, at Rs. 80 per mile -

Bungalow for assistant, improvements to present buildings at

Midelland plantation - $\quad$ - $\quad$ - $\quad$ - $\quad$ -

Plant nursery, including watering of seed beds - $\quad{ }_{150}$

Weeding (assuming the opening of the land to be in July

I 897) at R. I per acre for six months $=300$ by $6-1,800$

Cost of surveying lines round plantation, say -

I 75

900

300

160

Contingencies, such as special work, bridges over streams, or supplying vacancies, \&c.

Total actual outlay

- Rs. 8,782 


\section{Brought forward - \\ Special Expenditure.}

- Rs. 8,782

Salary of assistant for one year

Coolie to carry letters and orders

Tools (cost of supply)

Rs. $I, 000$

- 120

- 300

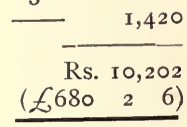

Estimated return off 300 acres of forest to be planted with rubber :-

600 trees sold standing at Rs. 2 per tree

- Rs. I, 200 Value of firewood and "ritti," after deducting cost of working,

Rs. ro per acre

Total credit of first year's work

Estimate of Cost of Purchasing too Acres of Land and Planting with Para Rubber.*

\section{Cost of 100 Acres of Land.}

Forest, say at Rs. 60 per acre

Chena, say at Rs. 40 to Rs. 45 per acre say Rs. 50.0 per acre Rs. 5,000

\section{Clearing-}

I00 acres of forest at Rs. 20

per acre

roo acres chena at Rs. I 5 to

Rs. I 7 per acre

Nurseries and seeds-

40,000 seeds at Rs. 7 per 1,000 - _ _ Rs. 280.0

30,000 baskets, Rs. 4 per 1,000 - - _ - 120.0

Making nurseries, including sheds for basket plants, sowing seed - $\quad-\quad-60.0$

Upkeep, watering for three months regularly - 30.0

Further occasional attendance for six months - 20.0

Carried forward - _ _ _ _ (n) 
Roads and drains, at Rs. 6 per acre -

Lining, say $\mathrm{I}_{5}$ by $\mathrm{I}_{5}$ feet, about 200 trees per acre, including cost of pegs, at 75 cents per acre

Holing-holes $\mathrm{I} 8$ by $\mathrm{I} 2$ inches, task $40^{\circ}$ per man, say R. I. 80 per acre

Planting - 20,000 basket plants, including transport from nurseries, dipping in liquid manure, \&c., 80 cents per acre -

Supplying-Putting out 6,000 basket plants at 50 cents per 100

Shading-

30,000 cadjans at Rs. Io per 1,000 Rs. 300

Making up, fixing, and general attendance, say

$$
\text { R. I.50 per acre - } \quad \text { - _ } \quad \text { - } 150
$$

Lines-One set of temporary lines, twenty rooms, jungle post thatched roof, mud and wattle walls, at Rs. 20 per room

Weeding-

Forest land-first three months at R. I.25 -

Thereafter at 80 cents say ten months weeding of first year at $R$. I. 50 per acre

Chena land-First three months at Rs. 2.50; second three months at R. I.75; thereafter at R. 1.0

Fencing-Cost of wire and staples, about Rs. I50 per mile, three wires at I foot apart; posts-cutting holes, \&c., Rs. I 87 per mile allowed and fixing, Rs. 30 per mile; per 3 miles carpenters at Rs. 7 per mile ?

Tools, say Rs. roo

Contingencies, Rs. 100 
Brought forward, first year's expenditure

Second Year-

Superintendence, say - $\quad$ - $\quad$ - $\quad$ Rs. I,000

Weeding 100 acres at R. I $\quad$ - $\quad$ - $\quad$ I,200

Nurseries, supplying, cadjans, \&c. $\quad$ - $\quad$ - $\quad$ I0

Roads and drains upkeep $\quad$ - $\quad$ - 50

Thatching lines, R. r.5० per room - $\quad$ - 30

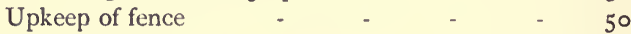

Contingencies - $\quad$ - $\quad$ - $\quad$ - $\quad$ - 100

$$
\text { Add interest on Rs. I 8, } 5 \text { I I at } 7 \text { per cent. - } \begin{array}{r}
2,535 \\
\mathbf{1}, 290 \\
\hline \text { Rs. } 19,806
\end{array}
$$

Third Year-

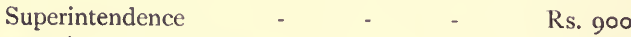

Weeding at 80 cents - $\quad$ - $\quad$ - 800

Supplying and nurseries - $\quad$ - $\quad$ - $\quad$ - $\quad 100$

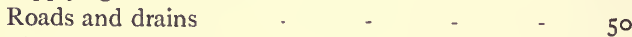

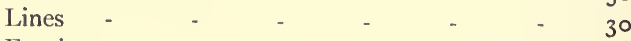

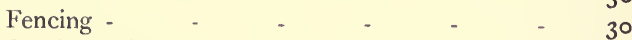

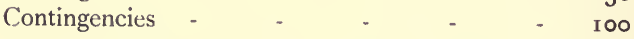

Add interest on Rs. 21,816 at 7 per cent. - - $\begin{array}{r}2,010 \\ 1,527\end{array}$

Rs. 23,343

Fourth Year-

Superintendence

Weeding at 75 cents

Supplying, \&c.

Lines, twenty rooms-permanent stone pillars, mud and wattle walls, iron roof, Rs. 70 per

Fencing room

Contingencies

Interest at 7 per cent.

$$
\begin{array}{rr}
1,400 \\
30 \\
70
\end{array} \quad \begin{array}{r}
3,070 \\
-\quad 1,848 \\
\hline \text { Rs. } 28,261
\end{array}
$$


Brought forward -

Fifth Year-

$\begin{array}{llll}\text { Superintendence - } & - & - \\ \text { Weeding - } & - & - & - \\ \text { Fencing - } & - & - & - \\ \text { Contingencies - } & - & - \\ \text { Roads, \&c., and general attention }\end{array}$

Interest at 7 per cent.
Rs. 28,26 I

\begin{tabular}{|c|c|c|}
\hline - & Rs. 900 & \\
\hline - & - $\quad 750$ & \\
\hline - & 50 & \\
\hline - & 70 & \\
\hline - & - $\quad 100$ & \\
\hline \multirow[t]{2}{*}{ - } & - & 2,109 \\
\hline & & 32,240 \\
\hline
\end{tabular}

Rs. 322.40 per acre at end of fifth year.

$$
\text { N.B.-Rupee }=\text { rs. } 4 \mathrm{~d} \text {. }
$$

\section{Memos.}

I close the estimate at termination of the fifth year as it is now generally admitted that tapping may commence according to growth between the end of fourth and sixth years. The estimate is framed on the lines of rubber planting as ordinarily carried on in the district of Matale, and might serve as a guide to the planting of rubber in such districts as Badulla Valley, Kurunegala, Dumbara, \&c., districts usually not heavily influenced by the rains of the south-west monsoon.

Felling.-The cost of felling and clearing both of forest and chena land is so very variable that it is impossible to give an estimate which would apply to the rubber districts generally.

Clearing.--In some districts I have had chena lands cleared for Rs. 9 per acre; and, again, the felling of forest will not be taken up by contractors in some localities for less than Rs. 25 per acre.

Roads and Drains.-The cost would be from Rs. 5 to Rs. 8 per acre according to lay of land, soil, \&c.

Fencing.-Fencing can only be estimated for by the mile. Many estates or clearings, covering perhaps only 100 to $15^{\circ}$ acres, would require 3 to 4 miles of fencing owing to established rights of way. My estimate is for a treble wire fence. It is not at all certain that it would not pay in cases where clearings have a jungle frontage to put up two wires only, say at I foot 6 inches and 3 feet, backed by galvanised wire 3 feet by 3 inches mesh. The cost of the barbed-wire fence would be reduced to Rs. 50 per mile. The galvanised wire would cost about Rs. 285 per mile. The total cost of such fencing would therefore work out at about Rs. 422 per mile. It would effectually put a stop to the depredations of muntjak deer, mouse deer, porcupines, and hares, and 
those who have clearings along a jungle edge know what damage such animals can do.

Planting.- The use of basket plants and shading with cadjans adds about Rs. 5 to Rs. 6 per acre to the cost of planting ; but results prove that this extra expense is well repaid.

Weeding.-This is an item which may very easily exceed the estimate I have given as regards chena lands. The first year's weeding should not, however, in any case cost over Rs. 3 per acre per month, say Rs. $3^{6}$ per acre for the year for the weediest chena lands. It may cost this unless labour is very plentiful. From fourth year the weeding should be reduced in either forest or chena land clearings to an average of 75 cents per acre.

Superintendence.-Has been estimated for on the supposition that the clearing is being looked after by the manager of an adjoining property. In the case of an estate of considerable acreage being concerned, this item would be chargeable at Rs. ro per acre per annum all through.

Buildings.-I makenoestimate for factory, superintendent's bungalow, $\& c$., though both would be required. Superintendent's bungalow could be built for about Rs. 2,000. It is useless at the present stage of the industry to make an estimate for a factory, as the invention of suitable machinery, which is sure to follow during the next year or two, will revolutionise the curing of rubber. It would probably be safe, however, to allow at the rate of Rs. 50 per acre as the cost of the building only.

Coast advances I have charged as an ordinary item of expenditure. It is only fair to do so, as it is an item which, though slightly varying in amount, is never absent, and is just as really a charge on the estate as superintendence or any other item, and should be recognised as such. The amount, Rs. 2,400, would probably be exceeded from and after the sixth year on tapping operations commencing.

Wiltshire, Matale,

E. Gordon Reeves. Ioth October 1905.

\section{Rubber in Malay Peninsula.}

Subjoined is Mr Arden's estimate applicable to a plantation in the Malay Peninsula :- *

* Report on Hevea brasiliensis in the Malay Peninsula. 
Cost of Opening and Maintrining a Plantation until Productive.

The following figures represent the cost of opening 500 acres of land, and planting with rubber 20 feet by 20 feet apart, being Io8 trees per acre.

Premium on 500 acres at $\$ \mathrm{I}$ per acre

Quit-rent, first year, 50 cents -

$\$ 500$

Survey fees, 25 cents per acre

Felling jungle, $\$ 7.50$ per acre

125

Clearing up, after burning off, $\$ 3$ per acre

3,750

Draining, \$ to per acre

$\mathrm{I}, 500$

Roads, \$1 per acre.

5,000

500

lining, \$1.50 per acre

750

Holing (holes $I_{2} \frac{1}{2}$ by $\mathrm{I}_{2} \frac{1}{2}$ foot) and filling with surface soil, \$I per acre

Planting with stumps from nurseries, 40 cents per acre

Weeding, \$I per acre per mensem (nine months)

Nurseries, sowing, weeding, and watering - _ _ $\quad 150$

Tools and implements

General transport

500

100

$\begin{array}{llllll}\text { Coolie lines, to house } 200 \text { coolies } & - & - & - & - & 750 \\ \text { Conductor's bungalow } & - & - & - & - & -\end{array}$

Manager's

$75^{\circ}$

Conductor's salary, first year, $\$ 50$ per mensem

900

Manager's

$\$ 300$

3,600

Contingencies

Total cost, first year -

$\$ 25,275$

This represents an average of $\$ 50.55$ per acre, although these figures are subject to a slight modification, varying with the nature of the jungle to be cleared and the land to be worked. The terms on which land may be acquired are dependent to a certain extent upon the situation and locality, and would not exceed the figures quoted above, but, subject to certain conditions, may be had on more reasonable terms. The proximity or otherwise to a town, and the facilities for transport would necessarily affect the estimate for transport charges. 
The upkeep for the second, third, fourth, and fifth years would be as follows :-

Quit-rent, 500 acres at 50 cents per acre (four years) $\$ 1,000$

Weeding, second year, 500 acres at 75 cents per acre per mensem

Weeding, third year, 500 acres at 65 cents per acre per mensem

Weeding, fourth year, 500 acres at 50 cents per acre per mensem

Upkeep of drains, 75 cents per acre per annum (four years) 1,500 roads, $75, \quad, \quad$, 1,500 250

Supplying vacancies, second year, 50 cents per acre per annum

Insect pests, \$2 per acre per annum (four years) 4,000

Repairs to coolie lines, second, third, and fifth years, \$25 per annum

Repairs to coolie lines, fourth year (re-ataping)

Repairs to bungalows (two), second, third, and fifth years, $\$ 25$ per annum

Repairs to bungalows (two), fourth year (re-ataping) -

Tools and implements, $\$ 25$ per annum (four years)

Vanager's salary, $\$ 3,600$

Conductor's salary, $\$ 600$

, ,

I 4,400

2,400

2,000

Contingencies, insecticides, stationery, \&c., $\$ 500$ per annum

Upkeep until end of fifth year Add first year's expenditure

\section{Total expenditure}

The total expenditure for five years is therefore $\$ 64,875$, being an average of $\$ 50.55$ per acre for clearing and planting, and $\$ 19.80$ per acre per annum for upkeep, including the manager's salary. Taking the rate of exchange at is. Iod. -the average for the last two years-this is equivalent to $£ 5$,946. I7s. 6d. sterling, or an average of $£ \mathrm{II}$. 7s. IO $\frac{1}{2} \mathrm{~d}$. per acre; to which must be added the interest on all money expended.

Nothing has been estimated for weeding during the fifth year, as it is anticipated that the trees will give sufficient shade 
to prevent the growth of any rank growing grasses; the weeds which appear during the fifth and subsequent years will be of a harmless nature, and will die out naturally as the shade becomes more dense. If it is considered advisable to weed beyond the fourth year, an additional estimate of 35 cents per acre per mensem should suffice to keep the estate perfectly clean.

The total expenditure necessary to bring rubber into bearing in Ceylon and Malay appears to vary from $£ 20$ to $£ 30$ per acre.

A perusal of a large number of rubber planting companies' reports shows that during 1906 the cost of rubber production on different estates in Ceylon and Malaya varied from $10 \frac{3}{4} \mathrm{~d}$. to Is. $7 \frac{1}{2}$ d. per lb. Rubber produced on one estate in Malaya cost, delivered in Ceylon, about 2s. per Ib. It is, however, considered that at present the cost of placing plantation rubber on the market varies between Is. and Is. $6 \mathrm{~d}$. per lb.

\section{PARA RUBBER CULTIVATION, F.M.S.}

Estimate for i,000 Acre Estate; 250 Acres to be Opened First Year-

$$
\text { each Year. (By R. G. Watson.) }
$$

Premium

Survey fees

Rent

Clearing, felling, and burning 250 acres $(\$ 15$ per acre)

Lining, holing, and planting $25^{\circ}$ acres ( $\$ 6$ per acre)

Plants

Roads and drains (\$6 per acre) -

Bungalow

Lines

Medical-Hospital, medicines, \&c.

$\$ 3,000$

Labour-Advances, immigration fees, \&c.

Superintendence -

Tools and sundries

I,, 000

$3,75^{\circ}$

$\mathrm{I}, 500$

800

I,500

2,000

I, 500

2,000

I,500

3,600

I,, 000 
Second Year-

Rent

Clearing, felling, and burning $25^{\circ}$ acres $\$ 1,000$

Lining, holing, and planting $25^{\circ}$ acres $3,75^{\circ}$ Plants

Roads and drains

Medical -

Labour -

Superintendence -

Tools and sundries

Weeding 250 acres

Supplying

Total

I, 500

800

I, 500

I,, 000

I,, 000

4,000

$75^{\circ}$

2,500

100

$\underline{\$ 17,900}$

Third Year-

Rent

$\$ 1,000$

Clearing, felling, and burning 250 acres -

Lining, holing, and planting 250 acres

Plants

Lines

Roads and drains

Medical -

Labour -

Superintendence -

Tools and sundries

Veeding 500 acres

Supplying

$\begin{array}{r}3,750 \\ I, 500 \\ 800 \\ I, 500 \\ 1,500 \\ 1,000 \\ 1,000 \\ 4,000 \\ 1,000 \\ 6,000 \\ 100 \\ \hline \$ 23,150 \\ \hline\end{array}$

Fourth Year-

Rent

Clearing, felling, and burning 250 acres -

Lining, holing, and planting 250 acres

Plants

Roads and drains

Medical -

Labour -

Superintendence -

Carry forward

$$
\begin{array}{rr}
- & \$ 1,000 \\
- & 3,750 \\
- & 1,500 \\
- & 800 \\
- & 1,500 \\
- & 1,000 \\
- & 1,000 \\
- & 4,000 \\
\hline & \$ 14,550
\end{array}
$$


PLANTATION ESTABLISHMENT AND MAINTENANCE. I65

Brought forward - $\quad$ - $\quad$ - $\quad \$ 14,55^{\circ}$

Tools and sundries

I,, 00

Weeding $75^{\circ}$ acres

Supplying

I 2,000

100

Total

$\$ 27,650$

Fifth Year-

Rent

Roads and drains

Medical -

Labour -

Superintendence -

Tools and sundries

Weeding $\mathrm{I}, 000$ acres

$\$ 1,000$

800

I,, 000

I,, 000

4,000

$\mathrm{I}, 000$

Total

I 5,000

$\$ 23,800$

Sixth Year-

Rent

Roads and drains

Labour

Medical -

Superintendence -

Tools and sundries

Weeding $\mathrm{I}, 000$ acres

$$
\begin{array}{rr}
- & \$ 1,000 \\
- & 800 \\
- & 1,000 \\
- & 1,000 \\
- & 4,000 \\
- & 1,000 \\
-\quad 17,000 \\
\hline
\end{array} \quad \begin{aligned}
& 15,800 \\
& \hline
\end{aligned}
$$

Total

Seventh Year-

Rent

Roads and drains

Medical -

Labour -

Superintendence -

Tools and sundries

Weeding $\mathrm{r}, 000$ acres

$\$ 4, \infty 00$

800

$\mathrm{I}, 000$

$\mathrm{I}, 000$

4,000

1,000

I 7,000

Total

$\$ 28,800$

Eighth and following years as seventh year

- $\$ 28,800$

With the exception that the cost of weeding gradually decreases till in the eleventh or twelfth year it is practically nil. 
Seventh Year-

\section{Profits.}

$25^{\circ}$ acres, planted $5_{50}$ trees per acre, at I lb. rubber per tree, sold at 3 s. per lb. $\quad-\quad \quad-\quad \quad$ - $\$ 48,2$ I 4 $25^{\circ}$ acres, planted $I_{50}$ trees per acre, at $I_{2} \frac{1}{2}$ lbs. rubber per tree -

\section{Total}

Less cost of production, shipping, \&c., of 93,750 lbs. at Is. $6 \mathrm{~d}$. per $\mathrm{lb}$.

60,268

Net profit - $\$ 60,267$

\section{Eighth Year-}

$25^{\circ}$ acres at $\mathrm{I} \mathrm{lb}$. per tree and $3 \mathrm{~s}$. per lb. $25^{\circ}$ acres at $I_{2} \frac{1}{2}$ lbs. per tree and 3 s. per lb. 250 acres at $2 \mathrm{lbs}$. per tree and $3_{3} \mathrm{~s}$. per $\mathrm{lb}$.

- $\$ 48,214$ 72,321 - 96,428

Total

- $\$ 216,963$

Less cost of production, \&c., 253, I25 lbs. at is. 6d. per lb.

$\begin{array}{r}-\frac{108,482}{\$ 108,481} \\ \hline\end{array}$

Net profit -

- $\$ 48,2$ I 4

$25^{\circ}$ acres at $\mathrm{I} \mathrm{lb}$. per tree and $3 \mathrm{~s}$. per $\mathrm{lb}$.

250 acres at $1_{2} \frac{1}{2} \mathrm{lbs}$. per tree and $3 \mathrm{~s}$. per lb.

500 acres at 2 lbs. per tree and $3 \mathrm{~s}$. per $\mathrm{lb}$.

- $\quad 72,321$

- 192,856

Total

- \$313,39I

Cost of production, \&c., 243,750 lbs. at is. 6 d. per lb.

Net profit -

- $\frac{156,696}{-\$ 156,695}$

Tenth Year-

$25^{\circ}$ acres at $\mathrm{I}_{2} \mathrm{l}$ lbs. per tree and 3 s. per lb. $75^{\circ}$ acres at 2 lbs. per tree and 3 s. per lb.

- $\$ 72,32 \mathrm{I}$

Total

- 289,280

Total

- $\$ 36 \mathrm{I}, 60 \mathrm{I}$

Carry forward

- $\$ 361,601$ 
PLANTATION ESTABLISIIMENT AND MAINTENANCE. I67 Brought forward - _ $\quad-\quad-\$ 361,601$

Less cost of production, \&c., 262,500 lbs. at Is. $6 \mathrm{~d}$. per lb.

- $\quad$ I 80,800

Net profit -

\$ 80,80 I

Eleventh Year-

I,, 00 acres at 2 lbs. per tree and 3 s. per lb.

$-\$ 385,710$

Cost of production, \&c., of 300,000 lbs. at Is. $6 \mathrm{~d}$.

per lb.

- 192,857

Net profit -

- $\$$ I 92,853

And so on each year, annual profit $\$ \mathbf{1 9 2}, 853$, with a probability of still increased yield.

A bstract or Profit and Loss.

\begin{tabular}{|c|c|c|c|c|c|c|}
\hline & & & & Expenditure. & $\begin{array}{l}\text { Profit on } \\
\text { Rubber. }\end{array}$ & $\begin{array}{c}\text { Net Profit on } \\
\text { Estate. }\end{array}$ \\
\hline & & & & $\$$ & $\$$ & $\$$ \\
\hline First & Year & - & - & 24, I 50 & $\ldots$ & $\ldots$ \\
\hline Second &, & - & - & I 7,900 & $\ldots$ & $\ldots$ \\
\hline Third & , & - & - & 23,150 & $\ldots$ & $\ldots$ \\
\hline Fourth & , & - & - & 27,650 & $\ldots$ & $\ldots$ \\
\hline Fifth & , & - & - & 23,800 & $\ldots$ & $\ldots$ \\
\hline Sixth & , & - & - & 25,800 & ... & $\ldots$ \\
\hline Seventh & , & - & - & 28,800 & 60,267 & 31,467 \\
\hline Eighth & , & - & - & 28,800 & I 08, 48 I & $79,68 \mathrm{I}$ \\
\hline Ninth & , & - & - & 28,800 & I 56,695 & I 27,895 \\
\hline Tenth & ", & - & - & 28,800 & I 80,80 I & 152,000 \\
\hline Eleventh & , & - & - & 28,800 & 192,853 & 164,053 \\
\hline Twelfth & ", & - & - & 28,800 & 192,853 & I 64,053 \\
\hline
\end{tabular}

Expenditure with interest at 5 per cent. up to end of sixth year - - - $\quad$ - $\$ 168,670(£ 20,000)$ 
Net Profit on Estate after deducting 5 Per cent. Interest on Capital.

Expended-

Seventh year - _ _ _ $\quad \$ 22,967$ or I 3 per cent.

Eighth " - - - - - $7 \mathrm{I}, \mathrm{I} 8 \mathrm{I}$ or $42 \quad "$

Ninth " - - - - - I I 9,395 or $70 \quad$ "

Tenth " - - - - - $\quad$ - 443,500 or $84 \quad$ ",

Eleventh , - - - - $\quad$ - 156,553 or $92 \quad$ ",

And so in future years with a probability of increased yields.

Capital expended

$\$ 168,670(£ 19,678 \quad 3 \quad 4)$

\section{Profit-}

Seventh year -

Eighth

Ninth

Tenth

Eleventh,

\begin{tabular}{|c|c|c|}
\hline$\$ 22,967$ & $(£ 2,679$ & \\
\hline $7 \mathrm{I}, \mathrm{I} 8 \mathrm{I}$ & $(8,304$ & \\
\hline I I 9,395 & $(13,929$ & 8 \\
\hline I 43,500 & $(\mathrm{I} 6,74 \mathrm{I}$ & 3 \\
\hline 156,355 & $(18,24 \mathrm{I}$ & 8 \\
\hline
\end{tabular}




\section{CHAPTER XV.}

COMMERCIAL VALUE OF THE OIL IN HEVEA SEEDS.

In addition to supplying the market with the finest quality of rubber, cultivators of Hevea brasiliensis will be in a position to compete in that enormous market which provides the world with vegetable oils.

The oleaginous nature of the seeds of this tree is well known, but an experiment has quite recently been made at the Imperial Institute to ascertain their commercial value as oil producers.

The difficulties of collecting these seeds in the Amazonian forest, together with the expenses of transporting them to the sea coast, would no doubt prevent the collection of the seeds from the wild trees being made a remunerative undertaking. But on a plantation these obstacles could be much more easily overcome.

About I 50 decorticated fresh seeds weigh a pound, which is about 340,000 to the ton. It is estimated that a Para tree produces on an average 400 seeds per year, so that about a quarter of a ton would be produced per acre. The seed kernels contain 50 per cent. of oil.

For the following paragraphs I am indebted to the Imperial Institute Bulletin :-

A considerable amount of activity has been displayed within the last few years in tropical countries in the cultivation of various kinds of rubber trees, in order to meet the growing demand for rubber in the arts. In the Federated Malay States large areas have thus been planted with the Para rubber tree (Hevea brasiliensis), and it has become nccessary to find a method of utilising the large quantities of seeds now produced in these plantations. Several consignments of these seeds and of meal prepared from them have been received recently at the Imperial Institute from the Assistant Superintendent of Forests 
and Gardens, Penang, and from the Curator of the Perak Museum, with the request that they should be examined and their commercial values ascertained. These samples have been submitted to chemical examination in the Scientific and Technical Department of the Imperial Institute, with the following results :-

The kernels constitute about 50 per cent. by weight of the whole seeds. On extraction with light petroleum they yielded 42.3 per cent. of oil (specimen A), whilst the whole seed (husk and kernel ground together) furnished 20 per cent. of oil (specimen B).

The oil obtained from the kernels alone is clear, of a light yellow colour, and has an odour somewhat resembling that of linseed oil. It belongs to the class of drying oils, and yields a clear, transparent film when allowed to dry by exposure to air. The husks contain a solid fat, which has a high saponification number and a low iodine value, but since the amount of this solid fat in the husks is very small, it makes but little difference to the properties of the oil obtained from kernel and husks ground together. The following table gives the constants found for both specimens of the oil, those of linseed oil being added for comparison :-

\begin{tabular}{|c|c|c|c|c|}
\hline & \multicolumn{2}{|c|}{ Para Rubber Seed Oil. } & \multirow{2}{*}{ Linseed Oil. } \\
\hline & & $\begin{array}{c}\text { A (from } \\
\text { kernels only). }\end{array}$ & $\begin{array}{c}\text { B (from } \\
\text { whole seed). }\end{array}$ & \\
\hline \multirow{3}{*}{\multicolumn{2}{|c|}{$\begin{array}{l}\text { Specific gravity at } \mathrm{r} 5^{\circ} \text { Cent. } \\
\text { Free fatty acids- } \\
\text { Acid value } \\
\text { Calculated as oleic acid }\end{array}$}} & 0.9302 & 0.9316 & $0.931-0.937$ \\
\hline & & 10.7 & 19.0 & $0.8-8.9$ \\
\hline & & $5.4 \%$ & $9.6 \%$ & $0.4-5.7 \%$ \\
\hline Ester value - - & - & 195.4 & 190.3 & ... \\
\hline Neutral oil - - - & - & $94.6 \%$ & $90.4 \%$ & $95.5-99.6 \%$ \\
\hline Saponification value & - & 206.1 & $209 \cdot 3$ & I $87-195$ \\
\hline Iodine value - & & I 28.3 & I $2 \mathrm{I} .2$ & $160-18 I$ \\
\hline
\end{tabular}

On saponification with caustic soda, Para rubber seed oil yields a rather soft soap of yellowish colour. It was found that the time required for the complete saponification of this oil is about half as much again as that required in the case of olive oil. 
The sample consisted of about $7 \mathrm{lbs}$. of finely ground meal of a pale buff colour; it was free from husk, and possessed the pleasant odour characteristic of oil meals.

On extraction with light petroleum, the meal yielded 36. I per cent. of an oil which had a slightlý acid odour, and, on standing, solidified as a soft, crystalline, yellow mass. It furnished the following constants:-

Specific gravity at $15^{\circ}$ Cent.

Free fatty
acids $\left\{\begin{array}{c}\text { Acid value - } \\ \text { Free acids (calculated as } \\ \text { oleic acid) }\end{array}\right.$

Neutral oil

Ester value

Saponification value

Iodine value
0.9 I I

- 130.5

65.6 per cent.

- 34.4 "

- $65.2 "$

- $195.7 "$

- $136.2 "$

When heated, the oil began to melt at $19^{\circ}$ Cent., and was a clear liquid at $28^{\circ}$ Cent. It had very marked drying properties, and yielded a solid, transparent film. On saponification with caustic soda, the oil furnished a rather soft soap of a yellowish colour.

In the following table the constants and properties of the oil extracted from this sample of meal are contrasted with those of the oil obtained from the freshly crushed decorticated seeds; the constants of linseed oil are again added for comparison :-

\begin{tabular}{|c|c|c|c|}
\hline & $\begin{array}{l}\text { Oil extracted } \\
\text { 1rom Para } \\
\text { Rubber } \\
\text { Seed Meal. }\end{array}$ & $\begin{array}{l}\text { Oil extracted from } \\
\text { Decorticated Para } \\
\text { Rubber Seeds } \\
\text { (freshly crushed). }\end{array}$ & Linseed Oil. \\
\hline Yield of oil per cent. & 36.1 & 42.3 & $33-37$ \\
\hline Physical state - - & $\begin{array}{l}\text { Solid below } \\
\text { I } 9^{\circ} \mathrm{C} \text {. }\end{array}$ & Liquid at $15^{\circ}$ & Liquid at $15^{\circ}$ \\
\hline Specific gravity $15^{\circ} / 5^{\circ}$. & $0.9 \mathrm{II}$ & 0.9302 & $0.931-0.937$ \\
\hline $\begin{array}{l}\text { Free fatty acids per cent. } \\
\text { (calculated as oleic acid) }\end{array}$ & 65.6 & $5 \cdot 4$ & $0.4-5.7$ \\
\hline Iodine value - & I 36.2 & 128.3 & $I 60-I 8 I$ \\
\hline
\end{tabular}

It will be observed that the oil extracted from the meal was solid, whereas that obtained from the freshly ground seed was a liquid. This difference is due to the large proportion (65.6 per 
cent.) of free fatty acids present in the former, whilst the latter contained only 5.4 per cent. of free acids. The cause of this difference in the two oils has been investigated, and it has been found that after the seed has been crushed the oil gradually undergoes decomposition, owing to the action of a hydrolytic enzyme contained in the seed, which will be made the subject of special study.

The meal furnished the following results on analysis :-

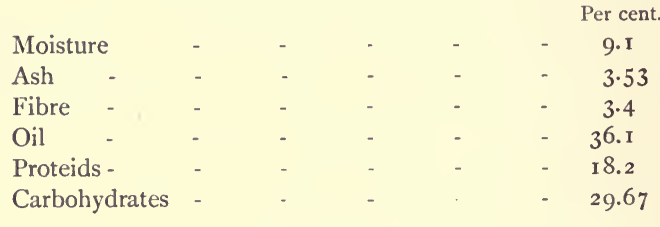

The ash was found to contain 30.3 per cent. of phosphoric acid (calculated as $\mathrm{P}_{2} \mathrm{O}_{5}$ ) present in the form of phosphates, which is equivalent to $\mathrm{I} .07$ per cent. of phosphoric acid in the meal.

The results of this examination of the Para rubber seed meal indicate that the material thus prepared could neither be used as a fodder, owing to the presence in it of large quantities of free fatty acids, nor for the expression of Para rubber seed oil since the latter has been largely decomposed.

\begin{tabular}{|c|c|c|c|c|c|c|c|}
\hline & $\begin{array}{l}\text { Moisture, } \\
\text { per cent. }\end{array}$ & $\begin{array}{c}\text { Ash, } \\
\text { per cent. }\end{array}$ & $\begin{array}{l}\text { Proteids, } \\
\text { per cent. }\end{array}$ & $\begin{array}{c}\text { Fibre, } \\
\text { per cent. }\end{array}$ & $\begin{array}{c}\text { Fat, } \\
\text { per cent. }\end{array}$ & $\begin{array}{c}\text { Carbo- } \\
\text { hydrates, } \\
\text { per cent. }\end{array}$ & $\begin{array}{l}\text { Nutrient } \\
\text { Value. }\end{array}$ \\
\hline $\begin{array}{l}\text { Calculated compo- } \\
\text { sition of- } \\
\text { Para rubber (seed } \\
\text { cake) - } \\
\text { linseed cake } \\
\text { (new process)- } \\
\text { Linseed cake(old } \\
\text { process)- } \\
\text { Cotton-seed cake } \\
\text { (new process)- }\end{array}$ & $\begin{array}{c}\text { I } 3.36 \\
9.4 \\
\text { I } 0.8\end{array}$ & $\begin{array}{l}5.19 \\
5 \cdot 4 \\
5.0 \\
6.10\end{array}$ & $\begin{array}{l}26.8 \mathrm{I} \\
35.6 \\
28.6 \\
38.47\end{array}$ & $\begin{array}{l}5.00 \\
7 \cdot 1 \\
6.7 \\
9.78\end{array}$ & $\begin{array}{c}6.00 \\
7.5 \\
10.6 \\
8.78\end{array}$ & $\begin{array}{l}43.64 \\
35.0 \\
38.3 \\
25.75\end{array}$ & $\begin{array}{l}84.25 \\
87.85 \\
91.28 \\
84.4\end{array}$ \\
\hline
\end{tabular}

It is probable, however, that if the oil were expressed from 
the decorticated seeds, the residual cake could be utilised as a feeding material, as is shown by the above comparison between the calculated composition of such a cake and the compositions of such commercial feeding cakes.

These figures show that a cake prepared from Para rubber seed meal would compare favourably with other cakes as a cattle food, and that it contains a particularly low proportion of indigestible matter (fibre).

Specimens of both the seeds and oil have been submitted to leading brokers. They report that the oil could probably be used as a substitute for linseed oil, and would be worth at present about $£ 20$ per ton, but that oil merchants would not take it up unless they first had an opportunity of testing it in bulk. The brokers consider that it would be more profitable to ship the seeds themselves to this country, as is done in the case of most other oil seeds. They value the decorticated seeds at $£$ IO to $£ \mathrm{I} 2$ per ton, and add that they would be prepared to take two or three tons at the lower price in order to introduce them into the market.

The Para rubber seed meal was not commercially valued, since in its present condition it could not be utilised in any way. Para rubber seed "cake" of the composition already given should be almost as valuable as linseed cake, which at present sells at from $£ 5$. I 5 s. to $£ 6$. I 5 s. per ton.

As a final result, this investigation leads to the conclusion that the seed of the Para rubber tree is a valuable economic product, and likely to become one of considerable commercial importance. The oil could probably be employed for the purposes to which linseed oil is applied, whilst the residual cake would be of value as a cattle food. The oil should be expressed from the kernels before these have been ground, and for this reason the seeds should, if possible, be decorticated and the kernels exported unground.

Para rubber seed oil possesses properties very similar to those of linseed oil, and should therefore be suitable for the preparation of paints and oil varnishes, and for the manufacture of rubber substitutes, linoleum, and water-proofing materials.

It could probably also be used like linseed oil for the manufacture of soft soap, but its colour would preclude its employment for the preparation of hard soaps except in cases where there is 
a scarcity of cotton-seed and similar light-coloured non-drying oils. It is intended to make further experiments regarding its applicability for manufacturing purposes.

As stated in the previous report, the cake left after expressing the oil from the decorticated seeds would probably be of value as a cattle food, since its calculated composition compares very favourably with the various cakes at present in use, and it is stated that animals in the Straits Settlements readily eat the kernels. 


\section{N D E X.}

\section{A}

Acid, Acetic, Ior, I I4, I 29

- action on latex, 129, 130

- Citric, 46, IOI

- Coagulating effect of, 129

- Formic, I33, I34

- Hydrochloric, Ior

- Oxalic, Ior

- Phosphoric, 45, 46, 49

-- Sulphuric, IOI

- Tartaric, IOI

Age of trees, Effect of, upon rubber, 68 Albuminous matter (vide Proteids), 96 Alkaline coagulants, IOI

Alkalinity of latex, 66

Analyses, 45, 64, 108, 120, 170, I7 I, 172 Antiseptics, I 30

Ants, white, Destruction of, 60

- white, Ravages of, 60

Areas planted with rubber, 4, I4

\section{B}

Bamboo pots for seedlings, 29

Bark shavings, $72,8_{3}$

- Tapping of renewed, 89,128

- Thickness of, 74

Baskets for seedlings, 30

Between-crops, 39

Biscuits, Rubber, 3, I02, 107

Blocking rubber, I 16

\section{C}

Calcium chloride, 137

Cambium tissue, 76
Canker of Hevea, 54

Caoutchouc globules, 66, 129, I 30

- Percentage of, in latex, 65

Carbon di-sulphide for white ants, 60

- di-oxide, 48

Cassava, 4 I

Catch-crops, 39

Chemical analyses, 64, 108, 120

Chillies, 4 I

Climatic conditions in Africa, 22

- conditions in Ceylon, $2 \mathrm{I}$

- conditions in Malay Peninsula, 22

Coagulants, I0I, I06

Coagulating machine, Io9

Cocoa, 39

Coffee, 39, 40

Collecting vessels, 89

Cortex, 56, 89

Cotton, 40

Creosoting latex, I29, 130

Crêpe rubber, I I3, I I 4

Crops, Leguminous, 49

Cultivation, 32

\section{D}

Disbudding, 43

Disease-checking belts, 5 I

- Fungus, 52

- Insect, 59

- Leaf, 58

- Root, 57

- Stem, 56

- Treatment of, 54, 6I

Drainage, 43

Drying rubber, $108,112,136$

- rubber, Artificial heat for, 102, 108 
Drying rubber by means of vacuum apparatus, 137

- rubber in stoves, 142

- rubber, Use of calcium chloride for, 137

\section{E}

Epidemics, 19

Erythrina used as shade for cocoa, 39

Estate plotting, 35

Estimated consumption of rubber, 2,9

- expenditure, 153

- production of rubber, 15

- yield of rubber, 15

\section{$\mathrm{F}$}

Factory, 123

Fences, 52

Fermentation, 129

Fertilisers, $48,50^{\circ}$

Flake rubber, 116

Floods, Injuries caused by, 34

Formalin, 67

Formic acid, 133, 134

Fungicides, 54

Fungus canker of Hevea, $5+$

- diseases, 52

- diseases, Treatment of, 54

- Losses due to, diseases, 52

- spores, Mode of infection by, 53

\section{G}

Grading rubber, 144

Green manuring, 49

Ground-nuts, 40

Growth, 22, 25

\section{$\mathrm{H}$}

Harrowing, 42

Heating of rubber, 93

Hevea brasiliensis, Description of, 2 I

- brasiliensis, Enemies of, 51

- brasiliensis, Growth of, 22, 25

- brasiliensis, Habitat of, 21

- brasiliensis, Latex of, 63

- brasilicnsis, Laticiferous system of, 63,76

- brasiliensis, Propagation of, 27

Hydraulic press, i 8

Impurities in rubber, 97

- Mechanical, 97

- Removal of, by straining, 109, 110 , 132

- Removal of, by washing, 97

Insecticides, 61

Insects, 59

- Checking ravages of, 60

- Habits of, 59

- Life history of, 59

- Trapping of, 60

Insoluble constituent in rubber, 94

Introduction of Hevea to the East, 4

\section{L}

Labour, is

Lace rubber, 98, 113

Latex, Action of acids on, 101

- Action of ammonia on, 67

- Albuminous matter in, 96

- Alkalinity of, 66

- Chemical composition of, 64

- Creosoting, 129, 130

- Decomposition of, 67

- Functions of, 63

- Mechanical impurities in, 97, 114

- Mineral matters in, 96

- Odour of, 66, 98

- Properties of, 64

- Proteids in, 96

- Resins in, 96

- Storing of, 66

- Variation of, 77

Laticiferous system, 63, 76

Laticifers, Origin of, 63,76

Lime, 47

Lining estates, 36,38

Litmus paper, 47, 67, I30

\section{M}

Machinery, Centrifugal, 109, I30

- Coagulating, 109

- Crêpeing, I14

- Washing, 123

Magnesia, 45 
Maintenance, 153

Maize, 4I

Manures, 48

Micro-organisms, 47

Mulching, 30, 48

Mycelium, 53, 55, 57

\section{$\mathrm{N}$}

Nitrification bacteria, $46,47,48$

Nitrogen, 45, 46, 49

Nurseries for seedlings, 28

- Shade for, 28

- Site for, 28

\section{$P$}

Packing rubber for export, $\mathrm{I} 44$ Para, Climate of, 21

Parasites, 52

Pests, Animal, 52

- Fungus, 52

- Insect, 59

Plantation, Site for, 33

-- rubber, Defects of, 128

Plants, Organic excretions of, 47

Preparation of rubber, 98

Pricking rubber trees, 76,87

Propagation by cuttings, 30

- by marcotting, $3 \mathrm{I}$

- by seeds, 28

Pruning, 43

Putrefaction of rubber, 132

\section{$\mathbf{R}$}

Rainfall in Africa, 22

- in Ceylon, 2 I, 33

- in Malaya, 22

- in Para, $2 \mathrm{I}$

Roots, Care of, ${ }_{3}^{8}$

Rubber, Adhesive principle of, 94

- Analyses of, 65, 95, 108, I20

- Areas of cultivated, 4, I4

- Artificial, 20

- biscuits, 3, 35, I02, I07

- Bitinga, 14

- Chemistry of, 64

- Collection of, 88
Rubber, Compressibility of, 93

- Congo, 12

- Consumption of, 2, 9

- Contractility of, 93

- Cultivated, 4, IO, I4

- Drying of, 112, 136

- East African, 13

- Effect of heat on, 93

- Effect of light on, 93, 129

- Elasticity of, 93

- Factory, 123

- Guayule, II

- Imports of, 2

- Insoluble constituent of, 94

- Madagascar, 13

- Mastication of, 98

-- Nervous principle of, 94, 97, IOI, 128

- Permeability of, 93

- Prices of Para, 7, 8

- Production of, 9, 27

- Properties of, 93

- Proteids in, 96

- Resiliency of, I33

- Resinous matters in, 66, 95, 97, I06, 135

- Seringa, 10

- Sheet, 107, 114

- Solubility of, 94

- Solvents of, 94

- Synthetic, 20

- West African, 12, I 47

\section{S}

Scrap rubber, II 9

- rubber, Crêpeing of, I 19

Seedlings in bamboo pots, 29

- in baskets, 30

Seeds of Hevea brasiliensis, 26, 28

- Germination of, 26

- Oil in, 168

- Selection of, 27

Shade-trees, 39

Sheet rubber, 107, II 4

Smoking rubber, 129

Soils, Biological condition of, 45

- Chemical condition of, 45 
Soils, Inoculation of, by bacteria, 46

- Moisture in, 45, 47, 50, 130

- Nitrogen in, 45

- Physical condition of, 44

- Potash in, 45

- Salt for, 50

Sulphur, Effect of, on rubber, 98

\section{$\mathrm{T}$}

Tackiness, Causes of, in rubber, 134 Tapping, Effect of over-, $8 \mathrm{I}$

- areas, 91

- Best time for, 68, 77, 78

- by pricking, 76,87

- Herring-bone, 82

- implements, 69

- operations, 68

- renewed bark, 89, 128

- Spiral, 83

- Various methods of, $69,88,148$
Tapping, V method of, $8 \mathrm{I}$ - Wounds caused by, 8 I Termites, Destroyer for, $6 \mathrm{I}$ Tillage, 42

Transplanting Hevea, 38

\section{V}

Vacuum drying, 97, 137

Vulcanisation, Effects of, 96

\section{W}

Washing Machines, 123

Weeding, 42

Worm rubber, I I 2, I 16

Wound response, $66,75,78,89$

\section{Y}

Yield of cultivated Para rubber, I 5, 27, 145 


\section{WALKER, SONS \& CO. LTD., COLOMBO, CEYLON,}

AND

\section{BASINGHALL STREET, LONDON, E.C.}

\section{RUBBER MACHINERY AND ACCESSORIES A SPECIALITY.}

Sole Manufacturers of the Michie-Golledge Coagulating Machine which was awarded the Gold Medal at the Ceylon Rubber Exhibition in 1906 for "The best method of coagulating latex to marketable rubber whether by acid, by decay, by smoking or otherwise."

The attention of Rubber Planters is specially requested to the Michie-Golledge Process for preparing Rubber in best "Worm," "Crepe," "Sheet," or other form. By this process Rubber from latex taken from the tree one day is cured in "Worm," "Crepe," "Sheet," or other form as may be required, and ready for shipment the following day; the quality being the best that can be produced. This simple process requires no expensive buildings nor heavy and expensive plant. It is much more economical than any other, and rubber prepared by it is thoroughly cured and possesses unequalled keeping qualities. Plans and Specifications for this process furnished on application.

\section{BARK GAUGING TOOL.}

This is a new and very ingenious instrument, designed by Dr W. R. Tromp de Haas. It enables the Estate Manager accurately, quickly, and without damage to the cambium, to gauge the thickness of the bark. Prices on application.

\section{TEA, COFFEE, RUBBER, AND OTHER MACHINERY}

supplied from Colombo and London to all parts of the World.

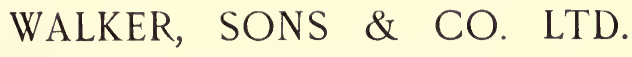




\section{CROSBY LOCKWOOD \& SON'S NEW LIST.}

Electricity in Factories and Workshops: Its Cost and Convenience. A I Iandbook for Power Producers and Power Users. By A. P. Haslam, M.I.E.E. 328 pp. With numerous Illustrations. Large crown 8vo. Cloth. 7s. 6d. net.

The Motor Car. A Practical Handbook for the use of Students and Motor Car Owners. With Notes on the Internal Combustion Engine and its Fuel. By Robert W. A. Brewer, A.M.Inst.C.E., M.I.M.E., M.I.A.E. 250 pp. With numerous Illustrations. Demy 8vo. Cloth. 5s. net.

Compressed Air Work and Diving. A Handbook for Engineers, comprising Deep-Water Diving and the use of Compressed Air for Sinking Caissons and Cylinders and for Driving Subaqueous Tunnels. By G. W. M. BoycotT, Assoc. M.Inst.C.E. With numerous Plates and other Illustrations. Medium 8vo. Cloth. Ios, 6d. net.

Petrol Air Gas. A Practical Handbook on the Installation and Working of Air Gas Lighting Systems for Country Houses. By Hexry O’Connor, F.R.S.E., A.M.Inst.C.E., \&c., Author of “The Gas Engineer's Pocket-Book." 80 pp. With Illustrations. Crown 8vo. Cloth. Is. 6d. net.

The Engineer's Year Book. Revised to date and Enlarged. Comprising Formulæ, Rules, Tables, Data, and Memoranda in Civil, Mechanical, Electrical, Marine, and Mine Engineering. By I. R. KEMPE, M.Inst.C.E., M.I.E.E. I, I 50 pp. With I, IO0 Illustrations. Crown 8vo. Leather. 8s.

British and American Customary and Metric Legal Measures. For Commercial and Technical Purposes. By Nelson Folev, M.I.N.A. Folio. Cloth. 7s. 6d. net.

A Pocket Glossary of English-Spanish, Spanish-English Technical Terms. Suitable for the Engineering, Manufacturing, and Mining Industries. By R. D. Monteverde, B.A. (Madrid). 316 pp. Waistcoat pocket size. Limp leather. 2s. 6 d. net.

The Ore Deposits of South Africa. With a Chapter on Hints to Prospectors by J. P. Johnson, Ex-Member of Council of Geological Society of South Africa, Certificated Mine Surveyor of the Transvaal, King's Prizeman in Metallurgy. Part I.-Base Metals. 70 pp. With Diagrams. Demy 8vo. Cloth. 5s net.

Marble and Marble Working. A Handbook for Architects, Sculptors, Marble Quarry Owners and Workers, and all engaged in the Building and Decorative Industries. Containing numerous Illustrations and 13 Coloured Plates. By W. G. Renwick. Demy 8vo. Cloth. Price I5s. (post free).

Wireless Telegraphy: Its Theory and Practice. A Handbook for the use of Electrical Engineers, Students, and Operators. By JAmes Erskine-Murray, D.Sc., Fellow of the Royal Society of Edinburgh, M.I.E.E. Second Edition, revised and enlarged. $388 \mathrm{pp}$. With over I 80 Diagrams and Illustrations. Demy 8vo. Cloth. 10s. 6d. net. 


\section{Crosby Lockwood \& Son's}

LIST OF WORKS

ON

\section{TRADES AND MANUFAC. TURES, THE INDUSTRIAL ARTS, CHEMICAL MANU- F A CTURES, COUNTING HOUSE WORK, ETc.}

A Complete Catalogue of NEW and STANDARD BOOKS relating to CIVIL, MECHANICAL, MARINE and ELECTRICAL ENGINEERING ; MINING, METALLURGY, and COLLIERY WORKING; ARCHITECTURE and BUILDING ; AGRICULTURE and ESTATE MANAGEMENT, \&c. Post Free on Application.

LONDON :

7, STATIONERS' HALL COURT, LUDGATE HILL, E.C., AND

121a, Victoria Street, Westminster, S.W.

1911. 



\section{LIST OF WORKS}

ON

\section{TRADES AND MANUFACTURES, THE} INDUSTRIAL ARTS, ETc.

ACETYLENE, LIGHTING BY. Generators, Burners, and Electric Furnaces. By WILliam E. GiBbS, M.E. With 66 Illustrations. $\begin{array}{lllllllll}\text { Crown 8vo, cloth } & \ldots & \ldots & \ldots & \ldots & \ldots & \ldots & \ldots & \text { 7s. 6d. }\end{array}$

AIR GAS LIGHTING SYSTEMS. See Petrol Air Gas. ALCOHOL (INDUSTRIAL): Its Manufacture and Uses. A Practical Treatise based on Dr. Max Maercker's "Introduction to Distillation" as revised by Drs. DELBRUCK and LANGE. By J. K. BRACHVOGEL. 500 pages, I05 engravings... $\quad \ldots \quad \ldots \quad$ Net 16 s. 6d.

The InuUstrial Value of Tax-free Alcohol and what it means to Agricultural Interests - Summary of the Processes in Spirit Manufacture-Starch, How Formed, its Characteristics, and the Changes it Undergoes-Enzymes or Ferments-Products of FERMENTATION-STarchy and Saccharifkrous Raw Materials-Preparation of the Malt-Steaming the Raw Material-The Mashing Process-Fermenting the MashPreparation of Artificial. Yeast in the Distillery-Fermentation in PracticeDistillation and Rectification-Arrangement of the Distillery-The Spent WashDenaturing of Alcohol-Alcohol for the Production of Power, Heating and IllumiNATION-STATISTICS.

ALKALI TRADE MANUAL. Including the Manufacture of Sulphuric Acid, Sulphate of Soda, and Bleaching Powder. By JoHN I.OMAS, Alkali Manufacturer. With 232 Illustrations. Super royal 8vo, cloth

BLOWPIPE IN CHEMISTRY, MINERALOGY, \&c. Containing all known methods of Anhydrous Analysis, many working examples and instructions for Making Apparatus. By LieUt.-ColoneL W. A. Ross, R.A., F.G.S. Second Edition. Crown 8vo, cloth ... 5 s.

BOOT AND SHOE MAKING, including Measurement, Lastfitting, Cutting-out, Closing and Making, with a Description of the most Approved Machinery employed. By J. B. Leno. Crown 8vo, cloth 2s. BRASS FOUNDER'S MANUAL. Modelling, Pattern Making, Moulding, Turning, etc. By W. Graham. Crown 8vo, cloth ... 2 2s.

BREAD AND BISCUIT BAKER'S AND SUGAR BOILER'S ASSISTANT. Including a large variety of modern recipes. By RoBert Wells. Fifth Edition. Crown 8vo, cloth ... ... Is.

"A large number of wrinkles for the ordinary cook, as well as the baker."-Saturday Reviecw.

BREAKFAST DISHES. For every Morning of Three Months. By Miss Allen (Mrs. A. MACAIRE), Author of "Savouries and Sweets," etc. Twenty-third Edition. F'cap 8vo, sewed, Is. ; fancy boards ... Is. 6d. 
BREWERS, HANDY BOOK FOR. Being a Practical Guide to the Art of Brewing and Malting. Embracing the Conclusions of Modern Research which bear upon the Practice of Brewing. By H. E. WRIGHT, M.A. Third Edition. Thoroughly Revised and Enlarged. Large crown $8 \mathrm{vo}, 578$ pp., cloth $\quad \ldots \quad \ldots \quad \ldots$ Net res. 6 d. Barley, Malting and Malt-Water for Brewing-Hops and Sugars-The Brewing Room-Chemistry as Aprlied to BREU1NG-The Laboratory-Mashing, Sparging, and Bolling-Ferments in Grneral-Fekmentation with Commercial Yeast-Culture from a Single Cell with Yeasts-Treatment of Beer-The Brewery and Plants.

CALCULATOR, NUMBER, WEIGHT, AND FRAC. TIONAL. Containing upwards of 250,000 Separate Calculations, showing at $\mathrm{a}_{\mathrm{e}}$ Glance the Value at 422 Different Rates, ranging from $\frac{1}{125}$ th of a Penny to 20s. each, or per cwt., and $£ 20$ per ton, of any number of articles consecutively, from I to 470 . Any number of cwts., qrs., and lbs., from I cwt. to 470 cwts. Any number of tons, cwts.. qrs., and lbs., from I to I,000 tons. By William Chadwick, Public Accountant. Fourth Edition, Revised and Improved. 8vo, strongly bound ... $\quad . . \quad$ I 8s.

CEMENTS, PASTES, GLUES AND GUMS. A Guide to the Manufacture and Application of Agglutinants for Workshop, Laboratory or Office Use. With 900 Recipes and Formulæ. By H. C. STANDAGE. Crown 8vo, cloth

\section{CHEMISTRY FOR ARMY AND MATRICULATION} CANDIDATES, AND FOR USE IN SCHOOLS. BY GEOFFREY MARTIN, B.Sc., Ph.D., Lecturer and Demonstrator in Chemistry at University College, Nottingham. Crown 8vo, cloth. With numerous

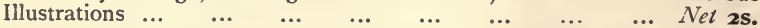

Preparation and Use of Apparatus-Preparation and Properties of Certain Gases And Liquids-Simple Quantitative Experimients-Analvtical Operations-SolubilityWater Crystallisation-Neutralisation of Acids by Bases, and Preparation of Simple Salts-Volumetric Analysis-Chemical Equivalents-Observation of Reaction-Melting And BoIling PoInts - Svmbols and Atomic Weights of the Elements-Weights and Measures-Hints on Regulating Work in Practical. Chemistry Classes.

CLOCKS, WATCHES, AND BELLS FOR PUBLIC PUR. POSES. BY EDMUND BECKETT, LOR1, GRIMTHORPE, LL.D., K.C., F.R.A.S. Eighth Edition, with New List of Great Bells and an Appendix on Weathercocks. Crown Svo, cloth. 4S. 6d. ; cloth boards, 5s. 6d.

COACH-BUILDING. A Practical Treatise, Historical and Descriptive. By J. W. Burgess. Crown 8 vo, cloth ... 2s. 6d.

COKE. MODERN COKING PRACTICE. Including the Analysis of Materials and Products. A Handbook for those engaged or interested in Coke Manufacture with Recovery of Bye-products. By T. H. Byrom, F.I.C., F.C.S., Chief Chemist to the Wigan Coal and Iron Co, and J. E. CHRistopher, Mem. Soc Chem. Industry, Lecturer on Coke Manufacture at the Wigan Technical College. 168 pages. With numerous Illustrations. Demy 8 vo, cloth.

[Just published. Net 8s. 6d.

General Classification of Furls-Coal. Washing-The Sampling and Valuation of Coal, Coke, etc.-The Calorific Power of Coal and Coke-Coke Ovens-Charging and Discharging of Coke Ovens-Cooling and Condensing Plant-Gas Exhausters-Composition and ANalysis of Ammuniacal Liquor-Working Up of Ammoniacal LiquokTratsiof of Waste Gases from Sulphate Plants-Valuation of Ammonium Sulphate Ovens-Useful Tables. 
COMMERCIAL CORRESPONDENT, FOREIGN. Being Aids to Commercial Correspondence in Five Languages-English, French, German, Italian, and Spanish. By ConRAD E. BAKER. Third Edition, Carefully Revised throughout. Crown $8 v$ o, cloth ... $\quad$ 4s. 6d.

"Whoever wishes to correspond in all the languages mentioned by Mr. Baker cannot do better than study this work, the materials of which are excellent and conveniently arranged."-Athenaum.

CONFECTIONER, MODERN FLOUR. Containing a large Collection of Recipes for Cheap Cakes, Biscuits, etc., with remarks on the Ingredients used in their Manufacture. By R. WELLS ... is.

CONFECTIONER'S AND PASTRYCOOK'S GUIDE. For Hotels, Restaurants, and the Trade in General, adapted also for Family Use. By R. Wells, Author of "The Bread and Biscuit Baker" is.

CONFECTIONERY, ORNAMENTAL. A Guide for Bakers, Confectioners and Pastrycooks; including a variety of Modern Recipes, and Remarks on Decorative and Coloured Work. With 129 Original Designs. By Robert Wells. Crown 8vo, cloth $\quad . . \quad$... 5 s.

COT'TON MANUFACTURE. A Manual of Practical Instruction of the Processes of Opening, Carding, Combing, Drawing, Doubling and Spinning, Methods of Dyeing, etc. For the Use of Operatives, Overlookers and Manufacturers. By J. LisTer. 8vo, cloth 7s. 6d.

\section{CRUSHING AND GRINDING MACHINERY PRAC-} TICE. A Handbook on the Machinery used in Crushing and Grinding Operations on all classes of materials. Including also a Glossary of Technical Terms and Bibliography. By THOS. G. MARLOw, Grinding, Drying, and Separating Machinery Specialist, Author of "Drying Machinery Practice." With numerous Tables, Plates, and Illustrations.

[In the press.

DANGEROUS GOODS. Their Sources and Properties, Modes of Storage and Transport. With Notes and Comments on Accidents arising therefrom. For the Use of Government and Railway Officials, Steamship Owners, etc. By H. J. Phillips. Crown 8vo, cloth 9s.

DENTISTRY (MECHANICAL). A Practical Treatise on the Coristruction of the Various Kinds of Artificial Dentures. By C. HUNTER. $\begin{array}{lllllllll}\text { Crown } 8 \text { vo, } \text { cloth } & \ldots & \ldots & \ldots & \ldots & \ldots & \ldots & \ldots & 3 \text { s. }\end{array}$

DISCOUNT GUIDE. Comprising several Series of Tables for the Use of Merchants, Manufacturers, Ironmongers, and Others, by which may be ascertained the Exact Profit arising from any mode of using Discounts, either in the Purchase or Sale of Goods, and the method of either Altering a Rate of Discount, or Advancing a Price, so as to produce, by one operation, a sum that will realise any required Profit after allowing one or more Discounts : to which are added Tables of Profit or Advance from $1 \frac{1}{4}$ to 90 per cent., Tables of Discount from $1 \frac{1}{4}$ to $98 \frac{3}{4}$ per cent., and Tables of Commission, etc., from $\frac{1}{8}$ to 10 per cent. By HENRY HaRben, Accountant. New Edition, Corrected. Demy 8vo,

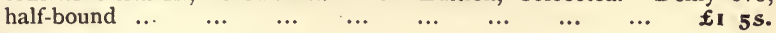


DRYING MACHINERY AND PRACTICE. A Handbook on the Theory and Practice of Drying and Desiccating, with Classified Description of Installations, Machinery, and Apparatus, including also a Glossary of Technical Terms and Bibliography. By THOMAS G. MaRLow, Grinding, Drying, and Separating Machinery Specialist. 340 pages, with 173 Illustrations and numerous Plates and Tables. Medium 8vo, cloth ... ... ... Just published. Net 12s. 6d.

Drving by Gravitation, Absorption, and Condensation-Mechanical Drving-Drying

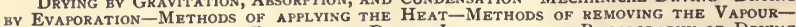
Handling the Materials-Evaporative Drving Installations-Bibliography of Drying and Desiccating-Glossary of Terms.

DRYING PROCESSES AND PATENTS. A complementary volume to "Drying Machinery and Practice." By THos. G. MARLOW. Describing the various Drying Processes as applied to Sundry Materials, also a Classified Summary of the Patents connected with Drying Processes and Apparatus ... ... ... [In the press.

ELECTRICITY IN FACTORIES AND WORKSHOPS : ITS COST AND CONVENIENCE. A Handbook for Power Producers and Power Users. By A. P. HASLAM, M.I.E.E. 328 pages, with numerous illustrations. Large crown $8 v 0$, cloth ... Net $\mathbf{7 s . 6 d .}$

ELECTRO-METALLURGY. A Practical Treatise. By AlexANDER WATT. Tenth Edition, enlarged and revised. Including the most Recent Processes. Crown 8vo, cloth ... $\quad \ldots \quad \ldots \quad \ldots \quad$ 3s. 6d.

ELECTRO-PLATING. A Practical Handbook on the Deposition of Copper, Silver, Nickel, Gold, Aluminium, Brass, Platinum, etc., etc. By J. W. Urquhart, C:E. Fifth Edition, Revised. Crown 8vo, cloth. 5s.

\section{ELECTRO-PLATING AND ELECTRO-REFINING OF} METALS. Being a new edition of ALEXANDER WATT'S "ElectroDeposition." Revised and Re-written by A. PHILIP, B.Sc., Principal Assistant to the Admiralty Chemist. Crown 8vo, cloth Net 125 . 6d.

PART I. ELECTRO-PLATING-PReliminary Considerations-Primary and SeconDARV BATteries-THERMOPILES-DYNamos-COST OF Electrical INSTAllations of SMall Output for Electro-Plating-Historical Review of Electro Deposition-El.eciro Defosition of COPPKR-DEPOSITION OF Gold BV Simple IMMRRSION-Elect Ro Deposition OF Gold-Various Gilding Operations-Mercurv Gilding-Electro Deposition of Silvekimitation Antique Silver-Electro Deposition of Nickel, Tin, Iron and Zinc, Various Metals and Alloys-Kecovery of Gold and Silver from Wash Solutions-Mechanical Operations connected with Electro Deposition-Materials Used in Electro DeposiTION. PART II. ELEC1RO METALLURGY-Electro METALLURGy OF COPPER-COST OF Electrolvtic Copper Refining - CuRrent Density as a Factur in Profits - Sume Important Details in Electrolvtic Copper Refineries-Electrolytic Gold and Silver Bullion Refining-Electrolvtic Treatment of Tin-Electrolvtic Refining of LeadElectrolytic Production of Aluminium and Electrolytic Refining of NickelElectro Galvanising.

ELECTRO-TYPING. The Reproduction and Multiplication of Printing Surfaces and Works of Art by the Electro-Deposition of Metals. By J. W. URQuhart, C.E. Crown 8vo, cloth $\ldots . . . \quad \ldots \quad 5$ s.

ENGINEERING CHEMISTRY. A Practical Treatise for the Use of Analytical Chemists, Engineers, Iron Masters, Iron Founders, Students and others. Comprising Methods of Analysis and Valuation of the Principal Materials used in Engineering Work, with numerous Analyses, Examples and Suggestions. By H. J. PHILlips. Third Edition, Revised. Crown $8 \mathrm{vo}, 420 \mathrm{pp}$., with Illustrations, cloth.

Net I os. 6d. 
EXPLOSIVES, MODERN, A HANDBOOK ON. A Practical Treatise on the Manufacture and Use of Dynamite, Gun-Cotton, Nitro-Glycerine and other Explosive Compounds, including CollodionCotton. With Chapters on Explosives in Practical Application. By M. Eissler, M.E. Second Edition, enlarged. Crown 8vo, cloth I2s. 6d.

"A veritable mine of information on the subject of explosives employed for military, mining and blasting purposes."-Army and Navy Garette.

EXPLOSIVES : NITRO-EXPLOSIVES. The Properties,

Manufacture, and Analysis of Nitrated Substances, including the Fulminates, Smokeless Powders, and Celluloid. By P. G. SANFORD, F.I.C., F.C.S., Public Analyst to the Borough of Penzance. Second Edition, Enlarged. With lllustrations. Demy 8vo, cloth Net Ios. 6d. Nitro-Glycerine - Nitro-Cellulote, etc. - Dynamite - Nitro-Benzol, Roburite, Bellite, Picric Acid, etc.-The Fulminates-Smokelass Powiders in Genrral-Analysis of Explosives-Firing Point, Heat Tests, Determination of Relative Strength, etc.

"One of the very few text-books in which can be found just what is wanted. Mr. Sanford goes steadily through the whole list of explosives commonly used; he names any given explosives, and tells of what it is composed and how it is manufactured. The book is excellent." - Engineer.

FACTORY ACCOUNTS: THEIR PRINCIPLES AND PRACTICE. A Handbook for Accountants and Manufacturers, with Appendices on the Nomenclature of Machine Details, the Income Tax Acts; the Rating of Factories, Fire and Boiler Insurance, the Factory and Workshop Acts, etc., including a Glossary of Terms and a large number of Specimen Rulings. By EMILE GARCKE and J. M. FELLS. Fifth Edition, Revised and Enlarged. Demy 8vo, cloth ... ... 7s. 6d.

"A very interesting description of the requirements of factory accounts. . . . The principle of assimilating the factory accounts to the general commercial books is one which we thoroughly agree with." - Accountants' Journal.

FLOUR MANUFACTURE. A Treatise on Milling Science and Practice. By FRIEDRICH KICK, Imperial Regierungsrath, Professor of Mechanical Technology in the Imperial German Polytechnic Institute, Prague. Translated from the Second Enlarged and Revised Edition by H. H. P. POWLES, A.M.Inst.C.E. 400 pp., with 28 Folding Plates, and

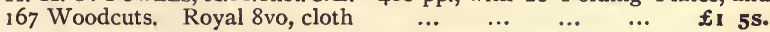
"This invaluable work is the standard authority on the science of milling."-The Miller.

FRENCH POLISHING AND ENAMELLING, including numerous Recipes for making Polishes, Varnishes, Glaze-Lacquers, Revivers, etc. By R. Bitmead. Crown 8vo, cloth... ... Is. 6d.

GAS ENGINEER'S POCKET-BOOK. Comprising Tables, Notes and Memoranda relating to the Manufacture, Distribution and Use of Coal Gas and the Construction of Gas Works. By H. O'ConNoR, A.M.Inst.C.E. Third Edition, Revised. Crown 8vo, leather.

Net I os. 6d.

GENERAL CONSTRUCTING MEMORANDA.-General Mathematical TablesUnloAding Materials and STORAGE-RerJRT HOUSE-Covdensers-BoIlers, Engines, Pumps and Exhausters-Scrubbers and Washers-Pukifiers-Gasholder Tanes-GasHOLDERS-WORKSHOP NOTES-MANUFACTURING-STORING MATERIALS-ReTORT HOUSE (WORKING)-CONDENSING GAS-EXHAUSTERS, ETC.-WASHING AND ScrubBing-PuRIFication -Gasholders (Care of)-Distributing Gas-Testing-Enriching Processes-Product WORKS-SUPPLEMENTARY.

"The book contains a vast amount of information."-Gas World.

GAS ENGINEERING. See also Producer Gas Practice and INDUSTRIAL GAS ENGINEERING. 
GAS FIT'TING. A Practical Handbook. By JoHN Black. Revised Edition. With 130 Illustrations. Crown 8vo, cloth 2s. 6d.

GAS LIGHTING. See Acetylene.

GAS LIGHTING FOR COUNTRY HOUSES. See Petrol AIR GAS.

GAS MANUFACTURE, CHEMISTRY OF. A Practical Manual for the use of Gas Engineers, Gas Managers, and Students. By HAROLD M. Royle, Chief Chemical Assistant at the Beckton Gas Works. With Coloured Plate and numerous Illustrations. Demy 8vo,

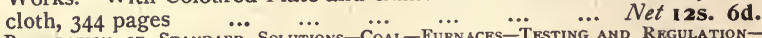
Preparation of Standard Solutions-Coal-Furnaces-Testing and RkgulationProducts of Carbonisation-Analysis of Crude Coal Gas-Analysis of Lime-Ammonia -Analysis of Oxide of Iron-Naphthalene-Analyses of Fire-Bricks and Fire-Clay, Weldon, and Spent Oxide-Photometry and Gas 'Testing-Carburetted Water GasMetropolis Gas-Miscellaneous Extracts-Useful Tables, etc.

GAS WORKS. Their Construction and Arrangement, and the Manufacture and Distribution of Coal Gas. By S. HUGHeS, C.E. Ninth Edition. Revised by H. O'ConNoR, A.M.Inst.C.E. Crown 8vo 6 s.

GOLD WORKING. JEWELLER'S ASSISTANT for Masters and Workmen, compiled from the Experience of Thirty Years' Workshop Practice. By G. E. GeE. Crown 8vo ... $\quad \ldots \quad \ldots$ 7s. $^{2}$.

GOLDSMITH'S HANDBOOK. Alloying, Melting, Reducing, Colouring, Collecting, and Refining. Manipulation, Recovery of Waste, Chemical and Physical Properties; Solders, Enamels, and other useful Rules and Recipes, etc. By G. E. GEE. Sixth Edition. Crown 8vo, cloth

3S.

GOLDSMITH'S AND SILVERSMITH'S COMPLETE HANDBOOK. By G. E. GEe. Crown 8vo, half-bound ‥ 7 s.

HALL-MARKING OF JEWELLERY. Comprising an Account of all the different Assay Towns of the United Kingdom, with the Stamps at present employed; also the Laws relating to the Standards and Hallmarks at the various Assay Offices. By G. E. GEe. Crown 8vo 3s.

HANDYBOOKS FOR HANDICRAFTS. By PAUL N. HASLUCK. See page 16.

HOROLOGY, MODERN, IN THEORY AND PRACTICE. Translated from the French of ClaUdius SAUniER, ex-Director of the School of Horology at Macon, by JuLIEN TRIPPLiN, F.R.A.S., Besançon Watch Manufacturer, and EDWARD RIGG, M.A., Assayer in the Royal Mint. With 78 Woodcuts and 22 Coloured Copper Plates.

Second Edition. Super Royal 8vo, £2 2s. cloth; half-calf $\boldsymbol{£ 2}_{\mathbf{2}} \mathbf{0}$.

"There is no horological work in the English language at all to be compared to this prodnction of M. Saunier's for clearness and completeness. It is alike good as a guide for the student and as a reference for the experienced horologist and skilled workman."-Horological Journal.

ILLUMINATING AND MISSAL PAINTING ON PAPER AND VELLUM. A Practical Treatise on Manuscript Work, Testimonials, and Herald Painting, with Chapters on Lettering and Writing, and on Mediæval Burnished Gold. With 2 Coloured Plates. By PHILIP WhithaRD (First-class Diploma for Illumination and Herald Painting, Printing Trades Exhibition, 1906). I56 pages. Cr. 8vo, cloth Net 4 s. 
INTEREST CALCULATOR. Containing Tables at $1,1 \frac{1}{2}, 2,2 \frac{1}{2}$, $3,3 \frac{1}{2}, 3 \frac{3}{4}, 4,4 \frac{1}{2}, 4 \frac{3}{4}$, and 5 per cent. By A. M. CAMPBELL, Author of "The Concise Calendar." Crown 8vo, cloth ... ... Net 2s. 6d.

IRON AND METAL TRADES' COMPANION. For Expeditiously ascertaining the Value of any Goods bought or sold by Weight, from Is. per cwt. to II $2 s$. per cwt., and from one farthing per pound to one shilling per pound. By THOMAS DownIE. Strongly

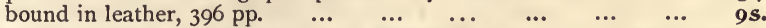

IRON-PLATE WEIGHT TABLES. For Iron Shipbuilders, Engineers, and Iron Merchants. Containing the Calculated Weights of upwards of 150,000 different sizes of Iron Plates, from I ft. by 6 ins. by $\frac{1}{4}$ in. to Io ft. by $5 \mathrm{ft}$. by I in. Worked out on the basis of $40 \mathrm{lbs}$. to the square foot of iron of $\mathrm{I}$ in. in thickness. By H. BURLINSON and

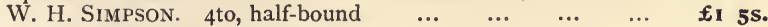

LABOUR CONTRACTS. A Popular Handbook on the Law of Contracts or Works and Services. By David GibBons. Fourth Edition with Appendix of Statutes by T. F. UTTLEY, Solicitor. F'cap. 8vo, cloth

3s. 6d.

LAUNDRY MANAGEMENT. A Handbook for Use in Private

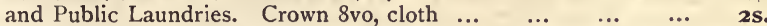

LAW FOR MANUFACTURERS, EMPLOYERS AND OTHERS, ETC. See "EvERY MAN'S OWN LAWYER." A Handybook of the Principles of Law and Equity. By a BARRISTER. Fortyseventh (1910) Edition, including the Legislation of $1909.830 \mathrm{pp}$. Large Crown 8vo, cloth ... ... ... [Published annually. Net 6s. 8d. SUMMARY OF CONTENTS:-LandLoRd AND TENANT - VENDORS AND PURCHASERSContracts and Agreements - Conveyances and Mortgages-Joint-stock CompaniesPartnership-Shipping Law-Dealings with Money-Surfisiship-Cheques, Bills and Notes-Bilis of SALE-Bankruptcy-Masters, Servants and Workmen-INSURANCE: Life, Accident, etc.-Copyright, Patents, Trade Marks-Husband and Wifr, Divorce-

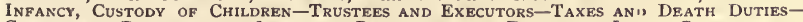
Clergymen, Doctors, and Lawyers - Parliamentary Elections-Local GovernmentLibel and Slander-Nuisances-Criminal. Law-Game Laivs, Gaming, InNkeEpers-Forms of Wills, Agreements, Notices, etc.

LEATHER MANUFACTURE. A Practical Handbook of Tanning, Currying, and Chrome Leather Dressing. By A. WATT. Fifth Edition, Revised and Enlarged. 8vo, cloth ... ... Net 12s. 6d. Chemical. Theory of the Tanning Process-The Skin-Hides and Skins-Tannin or Tannic Acid-Gallic Acid-Gallic Fermentation-Tanning Materials-Estimation of Tannin-Preliminary Opgrations-Depilation OR UNhairing Skins and Hides-Deliming or Bating-Tanning Butts for Sole Leather-Tanning Processes-Tanning by Pressure -Quick Tanning-Harness Leather Tanning-American Tanning-Hemlock TanningTANing BY Electricity-Chemical TANNING-Miscellankous Processes - Cost of American Tanning-Manufacture of Light Lrathers-Dyeing Leather-Manufacture of White Leather-Chrome Leather Manufacture-Box Calf Manufacture-Chamois or Oil Leather Manufacturf-Currying Machinery Employed in Leather ManufacTURe-Embossing Leather-Fellmongering-Parchment, Vellum, and Shagreen-Gut Dressing-Glue BoIling-Utilisation of TANneR's Waste.

\section{LEATHER MANUFACTURE. PRACTICAL TAN.}

NING. A Handbook of Modern Processes, Receipts, and Suggestions for the Treatment of Hides, Skins, and Pelts of every description, including various Patents relating to Tanning, with Specifications. By LouIS A. Flemming, American Tanner. Second Edition, in great part re-written, thoroughly revised, and much enlarged. Illustrated by 6 fullpage Plates. Medium 8vo, cloth. 630 pp. [Just published. Net 28s. 
MAGNETOS FOR AUTOMOBILISTS, HOW MADE AND HOW USED A Handbook of Practical Instruction in the Manufacture and Adaptation of the Magneto to the needs of the Motorist. By S. R. BotTone. Second Ed., Enlarged. 118 pages. With 52 Illustrations. Crown 8vo, Cloth $\ldots . \quad \ldots \quad \ldots \quad \ldots \quad$ Net 28.

MARBLE AND MARBLE WORKING. A Handbook for Architects, Sculptors, Marble Quarry Owners and Workers, and all engaged in the Building and Decorative Industries. Containing numerous Illustrations and 13 Coloured Plates. By W. G. RENwICK, Author of "The Marble Industry," "The Working of Marble for Decorative Purposes," etc. 240 pages. Medium 8vo, cloth $\quad . . . \quad \ldots .155$. The Chemistry of M ARble-Its Gelogical Formation-A short Classification of Marbles-ANTIQUity $N F$ THE Marbli INDUSTRY-ANCIENT QUARRIRS AND METHODS OF Working-Modern Quarries and QUarrying Methods-Machinfry usted in QuarryingEuropean and American Svstems compared-Marble as Building Material-Uses of Marble other than for Building Purposes-Sources of Production: Italian, French, Belgian, and Greek Marbles, etc.-Marbles of the United Kingdom and British Colonies-Continental Marble Working-Marble Working Machinerv-Marble WorkiNg in the United States-American Machinerv Described and Compared-Marble Working: A British Industry-Marble Substitutes and Imitations-Practical Points FOR THE Consideration OF ARchitects-Hints on THE Selection of Marblf-List of Marbles in Ordinarv Use, with Descriptive Notes and Instances of their Application.

MENSURATION AND GAUGING. A POCKET-BOOK containing Tables, Rules, and Memoranda for Revenue Officers, Brewers, Spirit Merchants, etc. By J. B. MANT. Second Edition. 18mo 4S.

METRIC TABLES, A SERIES OF. In which the British Standard Measures and Weights are compared with those of the Metric System at present in Use on the Continent. By C. H. Dowling, C.E. 8vo, cloth

METROLOGY, MODERN A Manul of the Metrical Un. 6d. Systems of the present Century, with an Appendix English System. By Lowis D'A. JACKSON. A M Int E "Aid to Survey Practice," etc. Large crown 8vo, cloth ... I 2s. 6d.

MOTOR CAR, THE. A Practical Manual for the use of Students and Motor Car Owners, with Notes on the Internal Combustion Engine and its Fuel. By ROBERT W. A. BrEWER, A.M.Inst.C.E., M.I.M.E., M.I.A.E. 250 pp. With numerous Illus. Demy 8vo, cloth. Net 5s. MOTOR CAR (THE MODERN), AND ITS MECHANISM. A practical Handbook on the Management and Maintenance of the Car for the use of Owners and Drivers. By W. Galloway Duncan, M.I.M.E., late Iemonstrator in Motor Car Engineering at Heriot-Watt College, Edinburgh, Author of "Handbook for Engineering Students," \&c. 122 pp. with Illustrations. Nearly ready. Price about Net 2S. 6d. CONTENTS:-Electrical IGNITION-ThE ENGINE-THE ENGINE ACCESSORIES AND Driving Gear-The Petrol, Water, and Lubricating Svstems-Tonls and Spares-Lamps -Driving-Touring-The Motor House-Technical Terms and Formula-Motor Car \&c., \&c.

MOTOR CAR ( ATECHISM. Containing about 320 Questions and Answers Explaining the Construction and Working of a Modern Motor Car. For the Use of Owners, Drivers, and Students. By JOHN HENRY KNIGHT. Second Edition, Revised and Enlarged, with an Additional Chapter on Motor Cycles. Cr. 8vo, with Illus. Net is. 6d. The Petrol Engine-Transmission and the Chassis-Tyres-Duties of a Car Driver - Motor CyCless-laws and Regulations.

MOTOR CARS FOR COMMON ROADS. By A. J. WALLIS-

TAYLER. 212 pp., with 76 Illustrations. Crown 8 vo ... 4s. 6 d. 
MOTOR VEHICLES FOR BUSINESS PURPOSES. A

Practical Handbook for those interested in the Transport of Passengers and Goods. By A. J. WAllis-TAyler, A.M.Inst.C.E. With 134 Illustrations. Demy 8vo, cloth … ... ... ... ... Net 9 s.

Resistance to Traction on Common Roads-Power Required for Motor VehiclesLight Passenger Vehicles-Heavy Pasaenger Vehicles-light Goods Vans-Heavy Freight Vehicles-Self-Propelled Vehicles ror Municipal Purposes-Misckllaneous Types of Motor Vehicles-Cost of Running and Maintenance.

OILS AND ALLIED SUBSTANCES. AN ANALYSIS. By A. C. WRIGHT, M.A.Oxon., B.Sc.Lond., formerly Assistant Lecturer in Chemistry at the Yorkshire College, Leeds, and Lecturer in Chemistry at the Hull Technical School. Demy 8vo, cloth ... ... Net 9s. The Occurrence and Composition of Otls, Fats, and Waxes-The Physical. Proprrties of Oils, Fats. and Waxes, and their Determination-The Chrmical Properties of Oils, Fats, and Waxes from the Analytical Standpoint-Detection and DetermiNation of NON-FATtY Constituents-Methods fOR Estimating the Constituents of Oils and Fats-Description and PROperties of, the more Important Oils, Fats, and WAXES, WITH THE METHODS FOR THEIR INVESTIGATION - EXamination OF Certain COMMERCiAL Products.

ORGAN BUILDING (PRACTICAL). By W. E. Dickson, M.A., Precentor of Ely Cathedral. Second Edition. Crown 8vo 2s. 6d. PAINTS, MIXED. THEIR CHEMISTRY AND TECH. NOLOGY. By MAXIMILIAN TOCH. With 60 Photomicrographic Plates and other Illustrations $\quad \ldots \quad \ldots \quad \ldots \quad \ldots \quad$ Net I 2s. 6d. The Pisiments-Yel.low, Blue, and Green Pigments-The Inert Filleks and ExTENDER:-PAINT VEHICLES-SPECIAL PAINTS-ANALYTICAL-AIPENDIX.

PAINTING FOR THE IMITATION OF WOODS AND MARBLES. As Taught and Practised by A. R. VAN DER BURG and P. VAN DER BURG, Directors of the Rotterdam Painting Institution. Royal folio, cloth, $18 \frac{1}{2}$ by $12 \frac{1}{2}$ in. Illustrated with 24 full-size Coloured Plates ; also 12 Plain Plates, comprising 154 Figures. 5th Edit. Net 25 s.

PAINTING, GRAINING, MARBLING, AND SIGN WRITING. With a Course of Elementary Drawing and a Collection of Useful Receipts. By E. A. DAvidSon. Ninth Edition, Coloured Plates. Crown 8vo, cloth, 5 s. ; cloth boards $\quad \ldots \quad \ldots \quad \quad \ldots \quad 6 s$.

PAPER-MAKING. 4 Practical Manual for Paper Makers and Owners and Managers of Paper Mills. With Tables, Calculations, etc. By G. Clapperton, Paper Maker. With lllustrations of Fibres from Microphotographs. Second Edition, Revised and Enlarged.

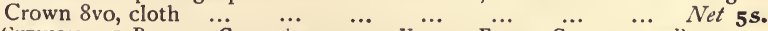
Chemical and Physical Charactrgristics of Various Fibres-Cutrting and boiling of Rags-Jute Boiling and Bleaching-Wet Picking-Washing, Breaking, and BleachingElectrolytic Bleaching-Antichlor-Cellulose from Wood-Mechanical Wood PulpEsparto and StraW-BEating-Loading-STARChing-Culuuring MatTeR-Resin, Size, and Sizing-The Fourdrinier Machine and its Management-Animal Sizing-Drying-Glazing And Burnishing-Cutting, Finishing-Microscopical Examination of Paper-Tests for INGREDIENTS OF PAPER-RECOYBRy OF SODA-TESTING OF CHEMICALS-TEsting WATER FOR IMPURITIKS.

"The author caters for the requirements of responsible mill hands, apprentices, etc., whilst his manual will be found of great service to students of technology, as well as to veteran papermakers and mill owners. The illustrations form an excellent feature."-The World's Paper Trade.

PAPER-MAKING. A Practical Handbook of the Manufacture of Paper from Rags, Esparto, Straw, and other Fibrous Materials. Including the Manufacture of Pulp from Wood Fibre, with a Description of the Machinery and Appliances used. To which are added Details of Processes for Recovering Soda from Waste Liquors. By A. WATT. $\begin{array}{lllllll}\text { With Illustrations. Crown } 8 \text { vo ... } & \ldots & \ldots & \ldots & \ldots & \text { 7s. } 6 \text { d. }\end{array}$ 
PAPER-MAKING, CHAPTERS ON. A Series of Volumes dealing in a practical manner with all the leading questions in connection with the Chemistry of Paper-Making and the Manufacture of Paper. By Clayton BEADLE, Lecturer on Paper-Making before the Society of Arts, I 898 and 1902, and at the Battersea Polytechnic Institute, I902, etc., etc. Each volume is published separately, at the price of $5 \mathbf{s}$. net per vol.

Volume I. comprises a Series of Lectures delivered on behalf of the Batter sea Polytechnic Institute in 1902. Crown 8vo, 151 pages

Net 5s.

CONTENTS:-Examination of Fibrous Raw Materials for Paper-Making-Art Papers As Aprlied to Process Printing-Bleaching-Chemistry of Bleaching-The Influence of Moisture on Paper-Chemical Residues in Paper-The Function of Water in the Formation of a Web of Paper-The Permanence of Paper-Sundry Physical Qualities of PAPER, ETC.

Volume II. comprises Answers to Questions on Paper-Making Set by the Examiners to the City and Guilds of London Institute,

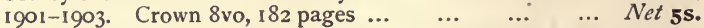

CONTENTS:-Technical Education as Applied to Paper-Making-The Use of Specially Prepared Size in Dry Sheets for Paper Sizing-Answers to Oroinary and Honours Grade Examination Papers, igoi-1903, Dealing with such Subjects as Mfasuring Thickness of Papers-Instruction to Beater Men-Estimation of Different Fibres, ETC., ETC.

Volume III. comprises a short Practical Treatise in which Boiling, Bleaching, Loading, Colouring, and similar Questions are

Discussed. Crown 8 vo, 142 pages ... $\quad \ldots \quad \ldots \quad \ldots \quad$ Net $\mathbf{5 s}$.

CONTENTS :- "Brass" and "Steel" Beater Bars-The Size and Speed of Beater Rolls-The Fading or Prussian Blue Papers - The Effect of Lowering the Breast RollThe Effect of "Loading" ON the Transparency of Paper- "Terra Alba" as a loading for Payer-The Use of Alum in Tub Sizing-The Influence of Temperature on Bleaching-The Use of Refining Engines-Agitation as an Auxiliary to Bleaching, etc.

Volume IV. contains Discussions upon Water Supplies and the Management of the Paper Machine and its Influence upon the Qualities of Papers. Crown 8vo, 164 pages $\quad \ldots \quad$... Net $\mathbf{5 s}$.

CONTENTS:-The Bulking of Papers-Special Qualities of "Art" Papeks-The "Ageing" AND Storage of PAPERs-The USE of Lime in BoIling-Controlling The Mark of THE "DANdv"- "Machine" and "HAND" Cut RAgS-Froth on the Paper Machine -Scum Spots in Paper-Consumption of Water in the Manufacture of Paper-The Managkment of Suction-boxes-The Shrinkage of Paper on the Machine, etc.

Vol. V. concerning THE THEORY and Practice OF BEATING. $\mathrm{W}$ ith Photomicrographs and other lllustrations. Crown 8vo, I90

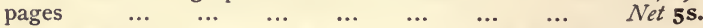

CONi ENTS:-Early Beating Appliances-The Hollander-The Economy of Beating-Difficllties of Arrivini at Definite Results-Behaviour of different Fibres"Refining" Power Consumption-A Comparison of two difFerent kinds of BeatersPOWer CONSUMED IN THE "BREAKING," "BeATING," AND "ReFining" OF DIFFERENT Materials-Dealing with the "Circulation" and "Agitation" in a HollandekCOMPARISONS OF LARGE AND MEDIUM-SIzED HOLlaNDERS WHEN BEATING "HARD" AND "SofT" Stock-Trials to determine the Relative Merits of Stone and Metal Beater-Bars'Trials with Breakers, Reed Beaters, and Kingsland Refiners, etc., etc.

PARA RUBBER. ITS CULTIVATION AND PREPARATION. By W. H. JuHnson, F.L.S., Director of Agriculture, S. Nigeria, West Atrica. Second Edition, re-written and enlarged, with numerous Illustrations. Demy $8 \mathrm{vo}$, cloth $\quad \ldots \quad \ldots \quad \ldots \quad \ldots \quad$ Net $\mathbf{7 s}$. 6d.

The World's Production and Consumption of Rubber-The Para Rubber Tree at Home and Abroad-Propagation-Planting and Cultivating-Solls and ManuresPests-Latex-Collecting the Latex-Rubber Manufacture-The Antisepticisation of KubBer-Drying and PACKING RUBber for EXPORT-Yield OF PARA RubBer From Cultivated Trees-Establishment and Maintenance of a Para Kubber PlantationCommercial. Value of the Oll, in Hevea Seeds. 
PETROL AIR GAS. A Practical Handbook on the Installation and Working of Air Gas Lighting Systems for Country Houses. By HENRY O'CONNOR, F.R.S.E., A.M.Inst.C.E., \&c., Author of "The Gas Engineer's Pocket Book." 80 pp., with Illustrations. Crown 8vo, cloth.

Net Is. 6d.

Description of Preyious Plants and Systems for Country-House Lighting, Diffi* culties with, Objections and Prices-History of Petrol Gas, Comparative CostsPetrol, Its Nature, Dangers, and Storing, Notes on the Law Regarding SameBurners, Description of same, Piping, Mantles-General Principles of Parts of Plants -Motive Power Meters-Weight-Driven Plants-Root's Blowers-Hot-Air EnginesPeltoN Water-Wheels-Descriptions of Various Plants-Extract from an Act for tuie Safe-Keeping of Petroleum and Other Substances of a Like Nature-AppendixUSEFUL NOTES.

PETROLEUM. THE OIL FIELDS OF RUSSIA AND THE RUSSIAN PETROLEUM INDUSTRY. A Practical Handbook on the Exploration, Exploitation, and Management of Russian Oil Properties, the Origin of Petroleum in Russia, the Theory and Practice of Liquid Fuel. By A. B. Thompson, A.M.I.M.E., F.G.S. 415 pp., with numerous Illustrations and Photographic Plates. Second Edition, revised. Super-royal 8vo, cloth

Net $\boldsymbol{f}$ I Is.

\section{PETROLEUM MINING AND OIL-FIELD DEVELOP.}

NENT. A Guide to the Exploration of Petroleum Lands, and a Study of the Engineering Problems connected with the Winning of Petroleum, including Statistical Data of Important Oil-fields, Notes on the Origin and Distribution of Petroleum, and a Description of the Methods of Utilising Oil and Gas Fuel. By A. BeEry Thompson, A.M.I.Mech.E., F.G.S., Author of "The ()il-fields of Russia." 384 pages. With numerous Illustrations and Tables and 22 full-page Plates. Demy 8 vo, cloth.

[Just published. Net 15 s.

PIGMENTS. AN ARTISTS' MANUAL ON. Showing their Composition, Conditions of Permanency, Non-Permanency, Adulterations, etc., with Tests of Purity. By H. C. Standage. Third Edition. Crown

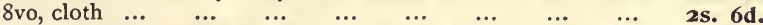

PORTLAND CEMENT, THE MODERN MANUFACTURE OF. A Handbook for Manufacturers, Users, and all interested in Portland Cement. By Percy C. H. West, Fellow of the Chemical Society and of the Society of Chemical Industry. Vol. I., "Machinery and Kilns." 280 pp., with 159 Illustrations and numerous Tables. Royal 8vo, cloth $\quad \ldots \quad \ldots \quad \ldots \quad$ [Just published. Net I 2s. 6d. Wash-Mills-Wet Edge-Runners and Stone Mills-Wet Tube-Mills-OTher Wet Mills and Accessory Plant - Wet Process - Crushers - Dryers - Millstones, EdgeRunNers, Disintegrators, \&c. - Ball-Mills - Centrifugal Roll-Mills - Tube-Mill.sConveyors and Eleyators - Dust Collectors - Weighini; Machines - Separators and Automatic Feeders-Pressing and Drying Briquettes-Shaft and other Stationary Kilns-Rotary Kilns-Coal Drying and Grinding-Storing and Grinding the ClinkerWarehousing and Packing the Cement-Descriptions of some Modern Cement Plants.

PRODUCER GAS PRACTICE (AMERICAN) AND INDUSTRIAL GAS ENGINEERING. By NISBET LATTA, M.Amer.Soc. M.E., M. Amer. Gas Inst. 558 pp., with 247 Illus. Demy 4 to, cloth [Just published. Net 258.

Producer Operation-Cleaning the Gas-Works Detalls-Producer Types-Moving Gases-Solid Furls-Phvsical Properties of Gases-Chemical Proterties of Gasps-Gas Analysis-Gas Power-Gas Engines-Industrial Gas Applications-Furnaces and KilnsBurning Lime and Cement-Pre-Heating Air-Doherty Combustion Economizer-Combustion in Furnaces-Heat: Temperature, Radiation, and Conduction-Heat Measure. ments : Pyrometry and Calorimetry-Pipes, Flues, and Chimneys-Materials : Firrclay, Masonrt, Weights, and Rope-Useful Tables-Oil Fuel Producer Gas. 


\section{RECIPES, FORMULAS AND PROCESSES, TWEN.} TIETH CENTURY BOOK OF. Edited by GARDNER D. HISCOX, M.E. Nearly I0,000 Scientific, Chemical, Technical and Household Recipes, Formulas and Processes for Use in the Laboratory and the Office, the Workshop and the Home. Medium 8vo, 800 pp., cloth

Net 12s. 6d.

Selected List of Contents. - Absinthe-Acid Proofing - Adhesives-AlcoholAlkali - Alloys - Aluminium - Ammonia - Aniline-Antidotes For Poison - Anchovy Preparations - Antiseptics - Antiques - Baking Powders - Barometers - BeveragesBleaching - Brass - Brick - Carbolic Acids - Casting-Celluloid-Cheese-CeramicsCigars - CoffeE-Condiments - Copper-Cosmetics-Cotton-Diamond Tests-DonariteDyes-Electro Plating-Embalming-Enamelling-Engraving-Essences-ExplosivesFertilisers - Filters - Food Adulterants - Grlatine - Glass - Gold-Gums-Harness DRESSINGS-HORN-INKS-INSECTICIDES-IRON-IYORY-JEWELLERS' FORMULAS - LACQUERSLaundry Preparations - Leather - Linoleum - Lubicants-Matches-Metals-Music Boxes-Oils-Paints-PaPek-Perfumes-Petroleum-Photography-Plaster-PlatingPolishes-Porcelain-Poultrv-Putty-Rat Poisons-Refrigeration-Ropes-RubberRust Preventives-Salt-Screivs-Silk-Silver-SoapS-Solders-Spirit-S -Songes-Steel - StONe - Thermometers - Tin - VAlves - Varnishes - Veterinary Formulas-WatchMAKER' FORMULAS-WATERPROOFING-WAX-WeightS AND MEasuRES-WhiteWASH-WOOD -YEAST.

RUBBER HAND STAMPS. And the Manipulation of Rubber. A Practical Treatise on the Manufacture of Indiarubber Hand Stamps, Small Articles of Indiarubber, The Hektograph, Special Inks, Cements, and Allied Subjects. By T. O'Conor SloANe, A.M., Ph.D. With

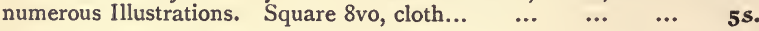

SAVOURIES AND SWEETS. Suitable for Luncheons and Dinners. By Miss M. L. Allen (Mrs. A. MACAIRE), Author of "Breakfast Dishes," etc. Thirty-first Edition. F'cap 8vo, sewed, rs. ;

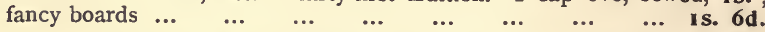

SHEET METAL-WORKER'S GUIDE. A Practical Handbook for Tinsmiths, Coppersmiths, Zincworkers, etc., with 46 Diagrams and Working Patterns. By W. J. E. Crane. Crown 8vo, cloth is. 6d.

\section{SHEET METAL WORKER'S INSTRUCTOR. Comprising} Geometrical Problems and Practical Rules for Describing the Various Patterns required by Zinc, Sheet-Iron, Copper, and Tin-Plate Workers. By R. H. WARN. Third Edition, Revised and further Enlarged, by J. G. HCRNER, A.M.I.M.E. Crown 8vo, 280 pp., with 465 Illustrations, cloth 7s. 6d.

SILVERSMITH'S HANDBOOK. Alloying and Working of Silver, Refining and Melting, Solders, Imitation Alloys, Manipulation, Prevention of Waste, Improving and Finishing the Surface of the Work, etc. By GEORGE E. GEE. Fourth Edition, Revised. Crown 8vo, cloth $3 \mathrm{~s}$.

SOAP-MAKING. A Practical Handbook of the Manufacture of Hard and Soft Soaps, Toilet Soaps, etc. With a Chapter on the Recovery of Glycerine from Waste Leys. By ALEXANDER WATT. Seventh Edition, including an Appendix on Modern Candlemaking. Crown 8vo, $\begin{array}{llllllllll}\text { cloth } & \ldots & \ldots & \ldots & \ldots & \ldots & \ldots & \ldots & \ldots & \text { 7s. } 6 d .\end{array}$

"The work will prove very useful, not merely to the technological student, but to the practical soap boiler who wishes to understand the theory of his art."-Chemical Nerws. 
SOAPS, CANDLES AND GLYCERINE. A Practical Manual of Modern Methods of Utilisation of Fats and Oils in the Manufacture of Soap and Candles, and of the Recovery of Glycerine. By L. L. LAMBORN, Massachusetts Institute of Technology, M.Am.C.S. Medium 8 vo, cloth. Fully illustrated. $706 \mathrm{pp}$. ... … … Net 30 .

The Soap Industry-Raw Materials-Blkaching and Purification of Soap-StockThe Chemical Characteristics of Soap-Stock and their Behayiour towards Saponifying Agents-Mechanical Equivalent of The Soal Factory-Cold Process and SkmiBoiled Soap-Grained Soap-Settled Rosin Suap-Milled Soap-Base-Floating Soap -Shaving Soap-Medicated Soap-Essential Oils and Soap Perfumery-Milled SoapCandles-Glycerine-Examination of Raw Materials and Factory Products.

\section{SOLUBILITIES OF INORGANIC AND ORGANIC} SUBSTANCES. A Hand-book of the most Reliable Quantitative Solubility Determinations. Recalculated and Compiled by ATHERTON SEIDELL, Ph.D., Chemist, Hygienic Laboratory, U.S., Public Health Service, Washington, D.C. Medium $8 \mathrm{vo}, 370$ pages ... Net I2s. 6d.

TEA MACHINERY AND TEA FACTORIES. Describing the Mechanical Appliances required in the Cultivation and Preparation of Tea for the Market. By A. J. WALlis-TAYLER, A.M.Inst.C.E. Medium $8 \mathrm{vo}, 468 \mathrm{pp}$. With 218 Illustrations ... ... Net 25 .

WAGES TABLES. At 54, 52, 50, and 48 Hours per Week. Showing the Amounts of Wages from one-quarter of an hour to sixty-four hours, in each case at Rates of Wages advancing by One Shilling from 4s. to 55 s. per week. By Thos. CARBUTt, Accountant. Square crown 8vo, half-bound ...

WATCH REPAIRING, CLEANING, AND ADJUSTING. A Practical Handbook dealing with the Materials and Tools used, and the Methods of Repairing, Cleaning, Altering, and Adjusting all kinds of English and Foreign Watches, Repeaters, Chronographs, and Marine Chronometers. By F. J. Garrard, Springer and Adjuster of Marine Chronometers and Deck Watches for the Admiralty. Second Edition, Revised. With over 200 Illustrations. Crown 8vo, cloth Net 4S. 6d.

WATCHES \& OTHER TIME-KEEPERS, HISTORY OF. By J. F. KENDAL, M.B.H.Inst. ... Is. 6d. boards; or cloth, 2s. 6d.

WATCHMAKER'S HANDBOOK. Intended as a Workshop Companion for those engaged in Watchmaking and the Allied Mechanical Arts. Translated from the French of CLAUDIUS SAUNIER, and enlarged by JUlien TRIPPlin, F.R.A.S., and EDWARD RIGG, M.A., Assayer in the Royal Mint. Fourth Edition. Crown 8vo, cloth ... ... 9s.

WEIGHT CALCULATOR. Being a Series of Tables upon a New and Comprehensive Plan, exhibiting at one Reference the Exact Value of any Weight from $1 \mathrm{lb}$. to 15 tons, at 300 Progressive Rates, from $1 d$. to 168 s. per cwt., and containing 186,000 Direct Answers, which, with their Combinations, consisting of a single addition (mostly to be performed at sight), will afford an aggregate of 10,266,000 Answers; the whole being calculated and designed to ensure correctness and promote despatch. By Henry Harben, Accountant. Sixth edition, carefully

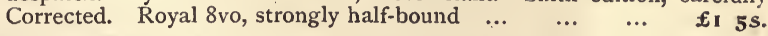

WOOD ENGRAVING. A Practical and Easy Introduction to the Study of the Art. By W. N. Brown. Crown 8vo, cloth. Is. 6d. 
This book is DUE on the last date stamped below

"MAY 311935

कीजिए in

$2 \times 02510$ की

OCT 26,1938

gar \& b 19:3i

DET 21 iss.

OCT 251937 APR 151947

Fov 11 19\%,

MAR 291938 JUN 121940 NOV 7 1938 JAN 9 195i.

APR 221944 FEB 7 1951:

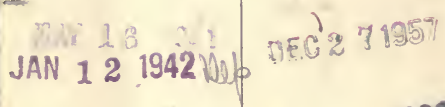

JAN 28 1942a NAY 91962

MAR $16 \quad 1942$ APRornit? 1949,

JUL 281942 Soliege

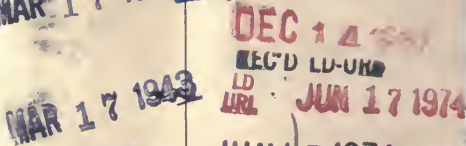
AUG 2-19:5 JUN 131974 Y DEC $22198 ?$ 
